Florida International University FIU Digital Commons

FIU Electronic Theses and Dissertations

University Graduate School

3-26-2008

\title{
El paradigma ético de la escritura martiana : desbordes de la modernidad
}

Carlos E. Cenzano

Florida International University

DOI: $10.25148 /$ etd.FI14060128

Follow this and additional works at: https://digitalcommons.fiu.edu/etd

Part of the Latin American Languages and Societies Commons, and the Latin American Literature Commons

\section{Recommended Citation}

Cenzano, Carlos E., "El paradigma ético de la escritura martiana : desbordes de la modernidad" (2008). FIU Electronic Theses and Dissertations. 2096.

https://digitalcommons.fiu.edu/etd/2096

This work is brought to you for free and open access by the University Graduate School at FIU Digital Commons. It has been accepted for inclusion in FIU Electronic Theses and Dissertations by an authorized administrator of FIU Digital Commons. For more information, please contact dcc@fiu.edu. 
Miami, Florida

EL PARADIGMA ÉTICO DE LA ESCRITURA MARTIANA: DESBORDES DE LA MODERNIDAD

A dissertation submitted in partial fulfillment of the

requirements for the degree of

DOCTOR OF PHILOSOPHY

in

SPANISH

by

Carlos E. Cenzano

2008 
To: Dean Kenneth Furton

College of Arts and Sciences

This dissertation, written by Carlos E. Cenzano, and entitled El Paradigma Ético de la Escritura Martiana: Desbordes de la Modernidad, having been approved in respect to style and intellectual content, is referred to you for judgment.

We have read this dissertation and recommend that it be approved.

Maida Watson

Erik Camayd-Freixas

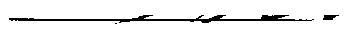

Lisandro Pérez

Ivan A. Schulman, Major Professor

Date of Defense: March 26, 2008

The dissertation of Carlos E. Cenzano is approved.

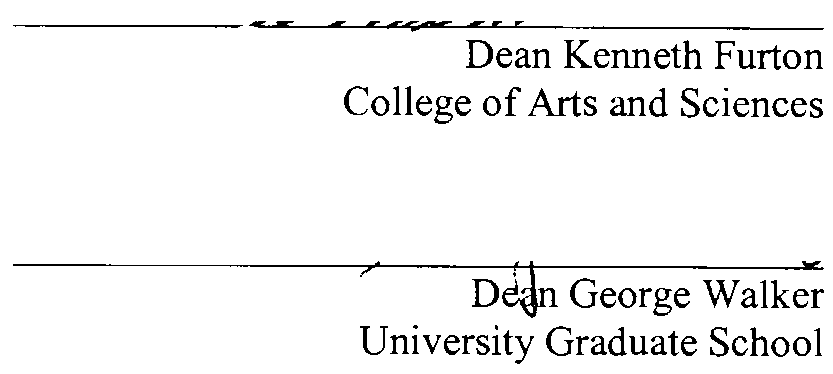

Florida International University, 2008 
(c) Copyright 2008 by Carlos E. Cenzano All rights reserved. 


\section{DEDICATORIA}

Dedico esta disertación a mi madre, por haber sembrado en mí el amor por los libros. Por ser una excelente guía espiritual de quien recibí los primeros ejemplos de conducta ética aún en las más adversas condiciones. Por su cariño, su ternura y su sabiduría natural y por su apoyo en mis aventuras poéticas y de superación profesional. 


\section{AGRADECIMIENTOS}

Deseo expresar mi sincero agradecimiento a los miembros del comité por sus valiosas aportaciones a esta tesis doctoral: a la Dra. Maida Watson, por su apoyo constante y sus valiosos consejos, al Dr. Eric Camayd-Freixas por sus meritorias enseñanzas y sus acertadas sugerencias, al Dr. Lisandro Pérez por abrir un espacio a mi disertación dentro de sus diversas obligaciones profesionales. Quiero agradecer, en especial, a mi director el Dr. Ivan A. Schulman por aceptar la dirección de mi disertación, por volverme, a través de su excepcional magisterio, a las lecturas martianas, por hacerme partícipe de su enciclopédico conocimiento de Martí y por ofrecerme su confianza, su valioso tiempo y ser un constante e inteligente guía en el proceso de mi investigación. Igualmente expreso mi agradecimiento a Graduate School por concederme Dissertation Year Fellowship que hizo posible que en el último año me dedicara plenamente a la investigación y a concluir este trabajo. 


\title{
ABSTRACT OF THE DISSERTATION \\ EL PARAGIDMA ÉTICO DE LA ESCRITURA MARTIANA: DESBORDES DE LA MODERNIDAD
}

by

\author{
Carlos E. Cenzano
}

Florida International University, 2008

Miami, Florida

\section{Professor Ivan A. Schulman, Major Professor}

This dissertation explores the nature of Jose Marti's ethical ideas in relation to the rise of late Nineteenth Century Modernity and in tandem with the deconstruction and subversion of the principal constituencies of colonial and aesthetic discourses. Martí proposes a new paradigm that question the insatiable pursuit of novelty, the hostility towards tradition, the historical perspectivism and a critical stance with regard to social aesthetic Modernity. He also questions the cult of reason, the linear historicism, and the teleological progress framed in philosophical utilitarian pragmatism of bourgeois Modernity. His radical criticism of the structures and institutions of the hegemonic power of the modern state override the ontological and epistemological foundations of Modernity. Marti's deconstruction of the fundamental discourses of euro-centristic Occidental culture leads him, through his ethical writings, to an arqueology of Native American civilizations, thus reinserting, within the false premises of European universalism, his counter-discourse of tradition and the voice of the Other. 
In examining Marti's ethical ideas we rely -though not exclusively- on the ethical theories of Michel Foucault, Emmanuel Levinas and Jacques Derrida. We argue that Marti's ethical writings reject the moral doctrines of Judeo-Christian tradition to constitute a subjectivity in opposition to the metanarratives of Modernity. This subjectivity modeled and sculpted by his eclectic thought and by poetic orphic views, coincides with the aesthetics of existence developed by Foucault in his late philosophical texts. The space Marti opens with his ethical writing coincides with the location of an alterity that goes beyond the Cartesian cogito and the ontology of reason and creates a humanism of the unconditional other that dictates the law and is open to the hospitality and absolute liberty developed by Levinas. We conclude that from the poetical dialectic of alterity that constitute Marti's ethical writing there emerges an ethical humanism based on heroic sacrifice and infinite love for humanity. That is his real thelos and the vehicle of his transcendence, the ultimate expression of his new paradigm. 


\section{ÍNDICE}

I. PARA UNA ARQUEOLOGIA DE LA ESCRITURA MARTIANA ............ 1

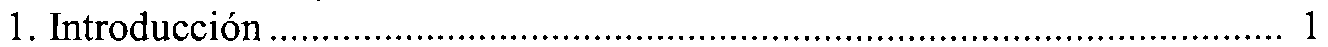

2. Consideraciones en torno a su estilo .......................................................... 12

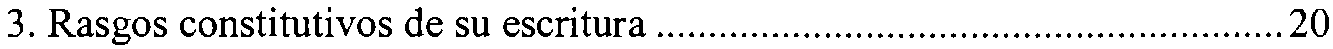

4. Instancias contra-discursivas y paradigmáticas de su escritura ética........... 31

5. Sentido hipertélico del lenguaje en Martíq ..................................................48

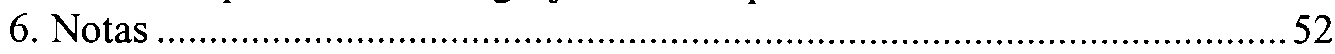

II. CONTRADISCURSO DE LA MODERNIDAD ESTETICA.........................55

1. La escritura martiana y la modernidad estética...........................................55

2. Desbordes modernistas de su escritura .........................................................61

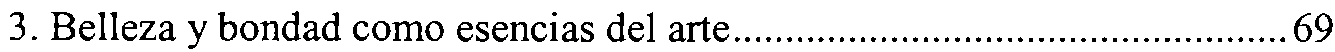

4. La literatura como servicio. Deber y verdad .............................................77

5. Optimismo martiano versus nihilismo modernista ...................................85

6. La fragmentación espiritual. Prólogo al poema del Niágara ......................98

7. La poesía como hermenéutica. Contra el discurso antropocéntrico ..........108

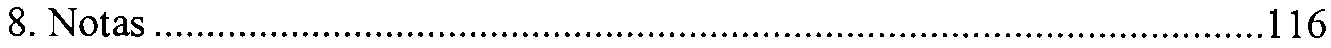

III. CONTRADISCURSO DE LA MODERNIDAD BURGUESA ....................119

1. La escritura martiana y su discurso anti-hegemónico................................119

2. Su contra-discurso euro-céntrico y universalista .....................................139

3. Minando el historicismo lineal y el progresismo teleológico ....................153

4. La escritura martiana y pensamiento científico moderno ..........................159

5. Contra el materialismo, el pragmatismo y el individualismo burgués.......168

6. Bancarrota de la tradición cristiana............................................................176

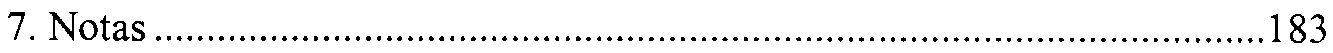

IV. ARQUEOLOGIA DE LA TRADICIÓN.................................................186

1. Los estudios culturales y el discurso martiano de la autoctonía ................186

2. La voz de la "América mestiza" .............................................................193

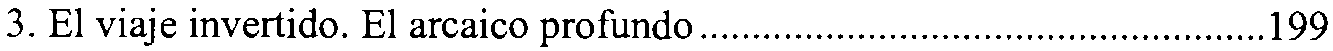

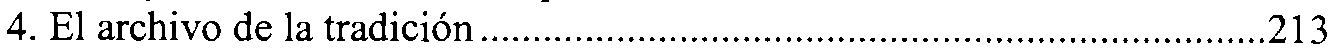

5. El "hombre natural" de América. Primitivismo vs. Modernidad..............229

6. Contra-discurso de las seudo teorías racistas europeas..............................235

7. Dignificación del hombre aborigen .........................................................240

8. La visión autóctona como antídoto contra el desarraigo ..........................245

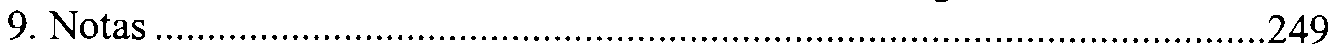

V. EL PARADIGMA ÉTICO DE LA ESCRITURA MARTIANA …..............251

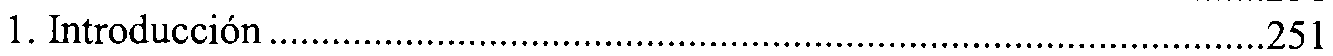

2. La escritura martiana y las teorías de la ética contemporánea .................257 
3. La estética de la existencia en Martí y Foucault .......................................268

4. La ética como primera filosofia: Martí Levinas y Derrida ........................286

5. El humanismo ético martiano ………………........................................310

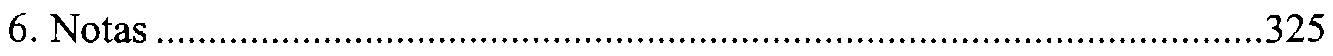

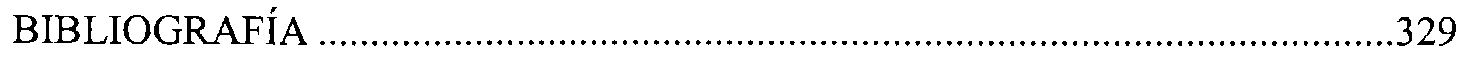

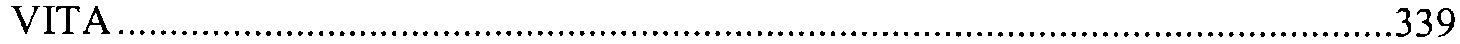




\section{Capítulo I}

Para una arqueología de la escritura martiana.

"Ni será escritor inmortal en América, y como el Dante, el Lucero, el Shakespeare o el Cervantes de los americanos, sino aquel que refleje en sí las condiciones múltiples y confusas de esta época, condensadas, desprosadas, ameduladas, informadas por sumo genio artístico".

José Martí.

"Quien escribe con sangre, y escribe sentencias, no ha de ser leído, sino aprendido de memoria".

Friedrich Nietzsche

\section{Introducción}

Hacia la década de 1870 la escritura martiana irrumpe en el ámbito de la literatura hispanoamericana mostrando una originalidad y una madurez inusuales para un escritor tan joven. La buena escritura es obra del tiempo. Es el resultado de una experiencia de vida y un trabajo artístico intenso, de un diamante que se ha pulido y depurando -como diría Antonio Machado- "golpe a golpe" y "verso a verso". Sin embargo, hay algo en el decir de Martí de sus primeros escritos que comienza a llamar la atención de sus contemporáneos, por esa prosa depurada y de un estilo sentencioso que ya aparece en $E l$ presidio político en Cuba (1871) de sus 18 años. Aunque esa escritura se enriquecería mucho más hacia principios de la siguiente década, lo que escribe en ésta no deja de sorprender por ser expresión de un signo de cierta rareza y magnetismo. Este texto enseña ya una frontera difusa entre prosa y verso que será sello de toda su creación artística. Hay en él otro elemento importante a destacar y es la densidad de las ideas que trata, al tiempo 
que cuestiona conceptos y principios de larga vida en el seno de la sociedad y la cultura. Es decir, desde sus inicios el organismo-escritura de Martí surge con un instrumental crítico que es, por naturaleza, consustancial a su pensar. En otras palabras, su pensamiento artístico no está interesado en recrear, sino en indagar y cuestionar la realidad que recibe como herencia. Esta peculiaridad crítica de su logos enseña ya desde la raíz que su constitución tiene como fundamento la búsqueda de una verdad escamoteada por el poder, la verdad del hombre todo. Por lo que su escritura es -desde que se abre a la vida-expresión de un carácter y un temperamento éticos que teñirán cada gesto y cada palabra suya. Estas peculiaridades de su creación se harán evidentes para sus lectores cordiales, sobre todo los poetas y los críticos de América y Europa. Según Pedro Henríquez Ureña su estilo llega "a su plenitud cuando frisaba los treinta, y a partir de entonces ninguna línea insignificante salió de su pluma, ya fuese un trozo de suelto periodístico o en una carta particular"l. Es decir Martí fue fiel al principio de que "la palabra es una conquista abominable cuando no se pone al servicio del honor y del amor", o parafraseando a Nietzsche, escribió con sangre y escribió sentencias para ser aprendido de memoria.

Ahora bien, debemos dejar claro, desde el inicio, que nuestro trabajo no persigue historiar el concepto del modernismo, ni las diferentes fases que conforman la modernidad, ni entrar en el debate de si es el iniciador del modernismo o figura cimera en él pues todo eso ha sido hecho con éxito por varios estudiosos de esta etapa. Estos aspectos se refieren en mi investigación de manera tangencial.con el propósito de ofrecer cierto marco referencial para el lector menos informado en la trayectoria martiana. Sin embargo esos factores -en nuestro criterio- tienen cada vez menor importancia en el 
contexto de los nuevos alumbramientos de su escritura. Nuestra disertación parte de definir, en primer lugar, que en Martí, más que una literatura, hay una escritura. De ahí que afirmemos que Martí -contrario a Darío- es un escritor sin literatura. En segundo lugar que esa escritura evoluciona más allá del discurso artístico y del discurso político, hacia una escritura que es ética por esencia y por naturaleza y que, siendo la matriz de su creación, absorbe y subsume el resto de su escritura. Para decirlo metafóricamente, su escritura ética es la fuente mayor en la que confluyen todas las demás corrientes discursivas de su pluma y en ella quedan fundidas. En tercer lugar demostrar que dicha escritura se da como contra-discurso de los metarrelatos de la modernidad a la que desborda, tanto epistémica como ontológicamente. En cuarto lugar que, como consecuencia de constituir su escritura como institución crítica de la modernidad, desbordando su episteme crea un nuevo paradigma que es esencialmente ético y como tal reverbera de manera inusitada en las expresiones teórico-filosóficas y culturales contemporáneas. Ese paradigma tiene su más extensa expresión en su viaje invertido, contrario al viaje del progresismo teleológico moderno, pues es un viaje hacia la tradición, al encuentro de su alteridad expresada en las voces sepultadas por el colonialismo. Es el viaje del arcaico profundo que hay en Martí desde una perspectiva arqueológica que busca romper la línea del historicismo lineal de occidente al reinsertar en el texto moderno la página que Europa había arrancado del libro de la historia: la de las civilizaciones autóctonas de América. Con esta hazaña epistémica y ontológica, que es ir hacia el pasado que la modernidad cierra su escritura ha dado el gran salto mortal para constituirse en una de las instituciones más desafiantes y revolucionarias de todo el pensamiento occidental. Esa decisión ético-filosófica y mito-poética desemboca en su 
humanismo ético, última estación de su peregrinaje intelectual. Este pensar su época al margen del discurso moderno y desafiando su episteme, además de crear e insertar su propio original pensamiento ético desde la periferia es el fundamento último del nuevo paradigma que inaugura en el contexto de la modernidad. Esa escritura ética, insobornable y audaz anuncia un orbe nuevo que es el orbe de la ética, la nueva etapa que la humanidad aguarda como ascenso a un nivel de integración y síntesis del espíritu y la materia -como una vez estuvieron-, la reconstitución de esa esfera en la que ambas mitades sean iluminadas con la misma intensidad y amor. El hecho de que su escritura penetre cada vez con mayor fuerza en el debate teórico del presente -como se verá en nuestra disertación - es una señal de que supo tocar la raíz y el alma de los problemas más álgidos de la existencia humana.

Mi disertación deconstruye $\mathrm{y}$ analiza las cuatro corrientes discursivas fundamentales de su escritura -la artística, la política, la autóctona y la ética. Un estudio de tal naturaleza no había sido emprendido antes tal y como lo desarrollo aquí. Ha sido suficientemente estudiado su discurso literario, vinculado al modernismo, con cierta porción de la crítica argumentando cómo Martí lo desborda. Ha sido estudiado su discurso político -con sus dos grandes vertientes: el discurso anticolonial y el discurso antiimperialista. Ha sido estudiado su discurso de la tradición y cómo en él desacredita las seudo-teorías del euro-centrismo. Y, finalmente, algunos -especialmente Cintio Vitier- se han acercado a su discurso ético. Sin embargo una arqueología que incluyera estos cuatro discursos y que propusiera como tesis fundamental que todos ellos desembocan en lo que defino como el paradigma de su escritura ética es lo que, desde mi punto de vista, es novedoso en mi disertación. Esta escritura ética es su gran aporte a la 
escritura moderna, pero desbordándola en todas las direcciones posibles. Intentamos un recorrido por su escritura para demostrar cómo va evolucionando y cómo en cada giro va cancelando los fundamentos onto-epistémicos de su época, que es todavía la nuestra. Lo que distingue a su escritura del resto de la de sus contemporáneos es que es crítica y ética por naturaleza, aunque esto al final $-\mathrm{y}$ después de saber lo que la teoría contemporánea propone sobre la lectura y la escritura- resulte ser una redundancia. El humanismo ético que proponemos como resultante de su escritura ética es -como veremos- opuesto al humanismo universalista y antropocéntrico occidental.

Uno de los primeros estudios en plantear el tema del carácter transgresivo de la escritura martiana es La dialéctica de la modernidad en José Martí donde Ángel Rama propone la relectura de sus textos a fin de revelar interpretaciones más hondas y acertadas de todo lo que palpita en la polivalencia de su signo. Comienza por citar a Federico de Onís quien en fecha tan temprana como 1934 ha dicho que la modernidad de Martí "apuntaba más lejos que la de los modernistas". Rama escribe este ensayo treinta y siete años después, o sea, en 1971 y en él, no sólo reafirma aquél criterio, sino que, además, añade sus propias observaciones y concluye que: "en Martí alentaba un cancelador de la modernidad como época de la historia humana" (131; énfasis mío). Esta afirmación es sumamente importante en tanto que -junto a las de los Vitier y Lezama- es la más atrevida y acertada hasta ese momento. El crítico plantea que ciertamente Martí había dado vida y había animado el surgimiento de esta nueva literatura que rompía definitivamente y por primera vez con la autoridad literaria peninsular, "pero a la vez proporcionó los argumentos negadores necesarios para su cancelación y superación dialéctica $(132)^{2}$. Para Ángel Rama se hace evidente que en la relectura de los textos 
martianos se detecta el nacimiento de una nueva literatura, al tiempo que su cancelación y superación y se anuncia una nueva sociedad ${ }^{3}$. Lo que realmente sucede con la escritura martiana es que cuando irrumpe en el ámbito de las letras hispanas no había el instrumental teórico capaz de detectar que el signo martiano superaba con creces el canon moderno y por eso su escritura fue situada dentro de los marcos de esa época. Es cierto que era nueva, es cierto que era la primera vez que la literatura hispanoamericana creaba un movimiento artístico adelantándose y superando los moldes peninsulares. Pero el error consistió en no comprender desde el inicio que lo Martí escribía -con sangre y con sentencias- superaba el marco de la literatura.

Cintio Vitier observa que Martí representa la "absoluta y militante antítesis de esa "estética nihilista" y de ese "mito vacío" al que se refiere Octavio paz en "El caracol y la sirena" de Cuadrivio (1965). Asimismo Fina García Marruz en "Los versos de Martí"4 sostiene que él ha sido señalado como "precursor del modernismo $[\ldots]$ iniciador y principal figura y su antítesis misma [...] Lo curioso no es que se hayan podido sostener tesis tan contradictorias sino que, de alguna manera, las tres resulten ciertas, a la vez que insuficientes" $(248)^{5}$. Por su parte Iván A. Schulman en Las entrañas del vacio plantea que "Martí anticipa a poetas como Pablo Neruda y César Vallejo" (89), al tiempo que reniega "de la ética de su época y de los moldes tradicionales estéticos sometiéndolos a una perspectiva crítica de la que no se excluye el mismo autor" (93). ${ }^{6}$ Los adelantos martianos de la vanguardia han sido igualmente señalados por la propia García Marruz en el ensayado antes citado y por Vitier en el prólogo a Martí, Dario y el modernismo, resultado de la colaboración del propio Schulman y Manuel Pedro González. Cintio Vitier se refiere a "la calidad pre-vallejiana de algunos textos de Martí, como los que 
proclaman su transido respeto por "la arruga, el callo, la joroba, la hosca / y flaca palidez de los que sufren", anunciadores de la audaz ternura humana del peruano..." (17). ${ }^{7}$ Finalmente en El proyecto inconcluso: la vigencia del modernismo (2002) Iván A. Schulman sostiene la tesis de que Martí "vislumbra la necesidad de un proyecto moderno alternativo, el de una contramodernidad regida por la virtud y el amor. De acuerdo con esto $[\ldots]$ elabora una narración contracultural que modifica los componentes del discurso liberal". ${ }^{8}$ Pero, a mi modo de ver, la reflexión más atrevida -sin dejar de mostrar cierta picardía criolla- es García Marruz en "Los versos de Martí":

Si la valoración de Darío -como hacen sospechar las intuiciones críticas de Juan Larrea- crece a la par que la de Martí, tendremos que el modernismo será un movimiento tan infeliz que no tendrá nombre -ya que Onís ha traspasado el suyo a toda una época-, ni precursores, porque los precursores son en realidad sus iniciadores, ni iniciadores, porque los iniciadores resultan ser sus contradictores, pudiendo darse el caso de que quede como un momento de imaginación de la crítica literaria. (249)

En la medida en que la crítica más exigente va teniendo acceso a la totalidad de la obra martiana gracias a las sucesivas publicaciones que de ella se van produciendo en los inicios del siglo $\mathrm{XX}$, comienza el proceso de revisión de la verdadera naturaleza de su escritura y de su alcance, en tanto se hace evidente que su palabra estaba envestida de una vitalidad que resistía los moldes estrechos de escuelas, movimientos, e incluso épocas. Por tal motivo Martí va, muy al principio, de ser un precursor del modernismo, a ser una figura central de éste, para luego convertirse en un escritor que apuntaba más lejos que los modernistas, hasta llegar a ser un cancelador de la modernidad según el criterio de Rama. El primero en cuestionar rotundamente la pertenencia de Martí al modernismo es Juan Marinello en José Martí: escritor americano de $1958^{9}$, aunque es justo señalar que 
Lezama, desde fines de la década del cuarenta revela con mucho acierto el alcance y la trascendencia de la palabra martiana, a partir de los estudios sobre la imagen en su sistema poético. ${ }^{10}$ Marinello entra en contacto con la obra martiana con la primera generación antiimperialista en la etapa seudo republicana, la que se agrupa en torno al Grupo Minorista. Su descubrimiento de Martí y de su contra-discurso colonial y antiimperialista ejerce gran influencia en las ideas revolucionarias de este grupo que, en última instancia, los convierte en protagonistas del derrocamiento de la dictadura de Gerardo Machado en 1933. Con esta generación comenzaba a cumplirse el vaticinio del propio Martí en cuanto al crecimiento futuro de su palabra, corroborado por Lezama quien, entre otras hermosísimas palabras decía en "Secularizad de José Martí" (1953) que como "testigo de su pueblo y de sus palabras, será siempre un cercado impedimento a la intrascendencia y la banalidad"ll. Sólo las dictaduras políticas que ha sufrido su pueblo, al confiscar y atenazar el pensamiento filosófico y cultural cubano, han abortado esta premonición lezamiana.

También los poetas, por la cualidad órfica de su mirada, pudieron desde muy temprano detectar la espesura de su signo, al tiempo que manifestaban deslumbramiento ante su palabra. Darío dice, entre otras cosas que "cada frase suya, si no es de hierro es de oro, o huele a rosas, o es llamarada [...] su pensamiento es un relámpago y su palabra un tímpano o una lámina de plata o un estampido" (71). ${ }^{12}$ Miguel de Unamuno, que su estilo epistolar recuerda el de Santa Teresa y que: "Ni está siempre escrito en prosa, sino en esa expresión informe, protoplasmática, que precedió a la prosa y al verso. Sus palabras parecen creaciones, actos"13. El filósofo y poeta español parece interpretar al propio Martí cuando dice que él quiere que se le considere primero como poeta en actos, antes 
de ser reconocido como poeta en versos, lo cual delata su sentido ético de la vida y su empeño de mejoramiento humano constante. Estas valoraciones apuntan a la naturaleza de una escritura que, por su espesura, se doblaba sobre sí misma al punto de parecer “actos", algo que no sólo corroboran las palabras de Unamuno, sino también las de Carl Jung, Roland Barthes, Julia Kristeva y otros teóricos quienes hablan de esta fusión del cuerpo y la letra, la carne y la palabra haciéndose una, como se cumple en Martí de manera especial. Esta atipicidad y latencia de su signo es lo que ha motivado la relectura de sus textos, practicando un examen más riguroso, procurando llegar a la raíz de su signo -como él pedía- utilizando el instrumental de la teoría y la crítica contemporáneas para ayudar en tal hermenéutica. Esa es la tarea que emprendo en mi disertación a partir de los trabajos de Theodore Adorno, M. Horkheimer, Roland Barthes, Jacques Derrida, Michel Foucault, Ludwig Wittgenstein, Emmanuel Levinas y Edward Said. Sin embargo, utilizo también las ideas de otros pensadores que desde fines del siglo XIX y toda la primera mitad del XX hacen aportes sustanciales en el ámbito de la epistemología y la ontología ya que sincronizan de modo peculiar con el pensamiento martiano. Me refiero a figuras como Friedrich Nietzsche, Carl Jung, Martin Hiedegger, Mircea Eliade, Joseph Campbell y otros. Digamos de paso, que este aspecto de la extrañeza y del carácter vivo de su escritura es el elemento más problematizador a la hora de clasificarla, a la vez que su mayor resistencia a los meta-relatos modernos.

De manera general, tanto los críticos, como los escritores han expresado esta perplejidad que dejamos expresada ante esta escritura. A todos se les antoja dinámica, actuante, expresión verbal similar a la de los salmos, antigua, clásica, barroca, romántica, moderna, vanguardista y algo más. Todo eso está representado en su escritura de ahí que 
ella demande esta especie de arqueología que aquí comenzamos, pero que ha de continuar, añadiéndole una genealogía si realmente queremos acceder a los corredores más profundos de esta escritura doble que es como una casa de espejos. Y es así porque ella vive todas las posibilidades expresivas de una palabra liberada de ismos, de dogmatismos, de filosofias, de sistemas; porque al apoderarse de la metáfora rompe su vínculo con la linealidad, con la causalidad, volviendo con ella a la naturaleza todo lo que ha sido desnaturaliza. Por todo lo anterior y porque piensa desde el ser del lenguaje -con la metáfora como primera hermenéutica- sus herramientas críticas también difieren de las de sus contemporáneos. Sólo a través de la poesía podía lograr la reunificación del mundo físico y del mundo espiritual que se había roto en el umbral del Iluminismo. De manera que más que un escritor es un arqueólogo y un etnólogo que desentierra y reexamina -sin pasiones miopes- los tesoros del alma de la civilización humana a fin de desmentir las falacias y las fabricaciones del universalismo occidental. Julio Ramos apunta que "en Martí opera una voluntad arqueológica -un discurso ineludible del arcnéque parecería ser motor de la escritura, en tanto dispositivo de orden y continuidad" (375), y cita este pensamiento martiano:

Interrogan esos buscadores con largas miradas los secretos de las piedras. Un vapor espiritual y luminoso emerge de los monumentos agrietados y negruzcos. Parece que las miradas ansiosas del observador ponen vida en las ruinas que observa. El estudiador las acaricia, como si fueran cosa suya, y muy amada, y las mueve con esmero, como si no quisiera lastimarlas. Y al fin la piedra cede, movida a la piedad de su amador, y le habla. (XIV, 762)

Este arqueólogo que hay en Martí no desentierra el pasado como testigo distante de la experiencia reconstructiva. Lo hace desde el amor: acaricia las piedras como si 
fuera cosa suya, como si lo que yace ahí inerte fuera parte de su ser, hablara su propia lengua. Hay una identificación y una empatía del lector-etnógrafo con el texto que desentierra. Y por eso se abren y le revelan sus secretos. Habrá que esperar hasta bien avanzado el siglo XX para que la antropología comience a producir una aproximación a las ruinas, no desde la extrañeza, sino en diálogo con el otro, en una polifonía de voces, para usar un término bajtiano. Pero esa es la aproximación dialógica es la que hace ya el poeta cubano a finales del siglo XIX. Esta vocación arqueológica de su pensamiento y de su escritura se enfrenta con justa indignación a esas teorías ciegas salidas de las mentes recalentadas de los "pensadores de lámparas" porque ha visto con su mirada órfica que el hombre es el mismo en todas partes, que de virtudes y defectos, de pequeñeces y grandezas son capaces todas las razas por igual y por eso considera que es un pecador contra la humanidad quienquiera que azuce odios raciales.

Uno de los conceptos manejados por la teoría contemporáneas es el de considerar la lectura y la escritura como instituciones de la crítica en el ámbito de la ética, de la cual se hace eco Frederic Jameson en su libro The Political Unconscious (1981) donde afirma que el modo predominante de la crítica de nuestro tiempo es la ética. Si esto es así tendremos que decir que Martí se adelanta y establece con su escritura, desde el siglo XIX, una institución crítica doble pues desde el mismo principio es una escritura que revela su naturaleza ética. Quizás ello explique la consistencia y durabilidad de sus criterios, a la vez que demuestre por qué su palabra desarticula los presupuestos del discurso moderno. Digamos ahora de paso que esta idea es corroborada con las teorías de Levinas, Derrida, Foucault, Wittgenstein, Blanchot, Deleuze y otros y está en la base de la escritura y el humanismo ético martianos. La crítica martiana se dirige a cuestionar los 
fundamentos epistémicos del estado moderno en su ejercicio de control absoluto del poder y del saber puesto que eso constituye el mayor impedimento a la realización plena del ser humano en tanto que se confisca su libertad y sus fuerzas físicas y espirituales y es enajenado del producto de su sacrificio personal. Este proceso de lenta deshumanización, desdibujado y edulcorado con falsas promesas de riqueza material y de sueños futuros (insertos en un mesianismo progresista) se constituye en el blanco de su denuncia porque es capaz de ver el peligro que acarrea esta visión para las aspiraciones de un mundo más justo y armónico para la humanidad. Así su escritura viene a ser portadora de un saber que está más a tono con los reclamos del presente que con los de su época puesto que incluye las voces periféricas y al hacerlo produce una de las primeras instituciones discursivas heterogéneas de la modernidad. A través de su escritura se reinsertan en el discurso político y estético modernos, de forma autorizada, las culturas marginadas por los colonialismos. En El proyecto inconcluso: la vigencia del modernismo, Iván A. Schulman, comentando esta idea-leitmotiv de su escritura ética, escribe: "En la composición de la nación, Martí, a diferencia de otros pensadores y estadistas de la modernidad americana, reconoció y aplaudió el principio de la hibridación cultural -la de los pueblos originales y singulares, como él decía" (36).

\section{Consideraciones en torno a su estilo}

Mi aproximación crítica a la obra martiana no se centra en el análisis del poeta del cronista, del crítico, ni siquiera en la dimensión de su discurso político que considero más bien resultado de una necesidad, más que una voluntad. Mi aproximación a Martí parte de 
su escritura ética, sin dudas la más entrañablemente humana y de mayor energía revolucionaria de toda su creación. Porque Martí no es un político, ni un sociólogo, ni un filósofo, ni un esteta, aunque en cada uno de esas dimensiones discursivas haya que consultarlo, porque en todas ellas es innovador y tiene algo luminoso que decir. Pero lo más atractivo de Martí es lo que convierte su ser en un arquetipo, perfectamente cincelado por él mismo como su mejor obra de arte. La dimensión humana de Martí, o más exactamente, su modo de ser humano, expresado en el sacrificio, el sufrimiento y la entrega absoluta por la causa común es lo que lo distancia de los meta-relatos modernos. Pocos creadores de su tiempo alcanzaron a configurar una cosmovisión del mundo tan abarcadora y universal como la suya. Quien sepa leer en el subtexto de su extensa obra podrá ver que ante todo fue un poeta que alcanzó a descifrar -siendo muy joven- las contradicciones aparentes de la vida y del mundo y supo liberarse de modo radical de la carga perniciosa y deshumanizante de la educación de su tradición. Es decir, supo deseducarse a tiempo - concepto que veremos más adelante cuando analicemos con Foucault la estética de la existencia- para comprender que en él estaba redivivo el hombre natural, telúrico, el que no había convertido en taller su morada porque era portador de un saber eficaz que entendía, ente otras cosas, que es absurdo destruir la casa común del hombre, desencantar el mundo y expulsar de él sus deidades para ofrecer a cambio promesas de un futuro de falsos ídolos y sueños vacuos.

No es de extrañar, pues, que una obra que cala tan hondo en las esencias humanas y en el entramado psíquico-social del hombre moderno haya sido objeto, por más de cincuenta años, de una exégesis que, con muy honrosas excepciones, no pudo y no supo más que tocar la superficie de su desafiante signo. Quizás sea lícito aceptar que hay 
rasgos de la estética modernista en alguna porción de su obra, pero en su escritura ética, que comienza hacia 1880 ya comienza a desembarazarse de los modos típicos de la estética modernista. Su obra, sobre todo, a partir de 1882 es abiertamente crítica de las dos modernidades y lo que critica de ambas no son elementos accidentales, sino sus fundamentos ideológicos. Es cierto que podemos hallar ciertos rasgos impresionistas o expresionistas en su obra, pero ni estos son exclusivos de la modernidad, ni los textos suyos donde aparecen son la tónica predominante. En ellos aparecen otros que recrean el barroco o el romanticismo o una prosa completamente ajena a la estética modernista. De modo que incluso en su primera etapa donde aparecen estos rasgos de la estética moderna, ya aparecen toros que no tienen nada que ver con esta estética, es decir hay una heterogeneidad o hibridez estilística en esa etapa que pudiera llegar hasta 1882. Después de esta fecha será dueño de una escritura con un estilo muy martiano y esa escritura se dará como contra-discurso de la modernidad.

En nuestro criterio personal los rasgos estilísticos de escuelas o épocas en que ha sido dividida la literatura no son suficientes para encasillar la obra de un escritor, si ese escritor, en el fondo, es además un pensador de rango universal que está dinamitando constantemente los presupuestos artísticos y estéticos de tales formaciones. Creo que es hora de tomar en cuenta el propio pensamiento de Martí, quien se pronuncia claramente contra todo encasillamiento del espíritu humano. En tal sentido vale la pena referir unas palabras de Cintio Vitier en la introducción que escribe a la correspondencia ente Martí y su entrañable amigo mexicano.

Fortalecer y agrandar vías es la faena del que escribe", declara a Manuel Mercado en carta donde lo que se siente resonar, como suele sucederle con entera naturalidad, es la prosa espiritual del Siglo de Oro, no Mallarmé o 
Huysmans, sino Santa Teresa o San Juan de la Cruz, lo que en buena parte explica el enigmático desconocimiento de Martí por parte de los que son, hasta nuestros días, consecuencia de los primeros, no de los segundos. Y así en dicha carta leemos efusiones y finezas, de firme y sana raíz espiritual, que a los oídos de la versión francesa o anglosajona de la modernidad literaria deben sonar a prescindible anacronismo. ${ }^{14}$

Su modo de percibir y asimilar la realidad parte de su sentido de la expansión del espíritu humano, del penetrar nuevas certidumbres, de traspasar con su palabra toda limitación, toda atadura, toda reducción. No le interesó pertenecer -como sí su admirador Darío- a ninguna escuela, o movimiento o época, como tampoco asociarse a ningún sistema filosófico porque le parecía cosa de rebajarse al reduccionismo que él criticaba. Incluso se refirió a la nueva literatura hispanoamericana que había proclamado su independencia de las metrópolis europeas como a una generación robusta que comenzaba a dar sus primeros pasos en la creación de un arte auténtico. Rara vez utilizó el término modernismo para referirse a eso que Rubén Darío consideraba haber iniciado, ni nunca se sintió parte de ese grupo que imitaba las técnicas y los modos de la escuela francesa, porque eso no era de su interés, como tampoco la institución literaria porque no era el destino de su viaje. Su mirada estaba situada en tareas más acuciantes y álgidas de la vida de la sociedad de su y su escritura destinada a poner sus manos amorosas y justas en las entrañas del hombre que le fue contemporáneo a fin de contribuir, con el esclarecimiento de la verdad, al alivio de sus dolores y penas. Después de 1882, habiendo decidido que su destino será la lucha contra toda forma de explotación y de colonialismo, su escritura se radicaliza más aún. No sólo desenmascaró con ella las falacias discursivas de su época, sino que elaboró su propia episteme fronteriza para atacar al aparato hegemónico del poder, contaminándolo de su telos eto-poético. Su ejercicio del criterio no vacila en 
arremeter contra la literatura europea, sobre todo contra los maestros franceses, quines se entretenían en la forma mientras la modernidad burguesa fraguaba sus estatutos de hegemonía y control.

Si aceptamos la idea de que un escritor pertenece a una generación o grupo o época porque encontramos cierta técnica en su arte que remeda la en uso por los artistas de su momento, entonces donde colocamos el barroco de Martí, o su romanticismo, o su clasicismo que no estaba en los modernistas. Cualquier crítico podría, sin pecar de impreciso, calificar a Martí de barroco -como efectivamente lo han hecho- porque lo es en mucho sentido o calificarlo de romántico puesto que con esa estética también guarda afinidades. Y es que estas tres modalidades representan actitudes existenciales, modos de ser en los que los artistas se han cuestionado críticamente su realidad y con eso él encuentra afinidad. De modo que Martí es barroco por la densidad de su estilo, por ciertos giros idiomáticos y períodos sintácticos que detectan un acercamiento con esa expresión artística del siglo XVII. Tal percepción es razonable si se analizan sus trabajos a Calderón donde se aprecia la recreación de la escritura barroca, lo mismo que un análisis estilístico puede mostrar que en la acumulación y la complejidad de sus giros sintácticos está presente la estética barroca. ¿Es Martí por eso un escritor barroco? Pudiera serlo. Pero hay un hondo pesimismo en la conciencia del hombre del siglo XVII, consecuencia de la crisis que la sociedad vive en todos los órdenes de la vida, que no está en Martí. Su identificación con el barroco tiene esencialmente que ver con las preocupaciones sociales que embragaba a los escritores artistas de la época, con su interrogación sobre el sentido de la existencia humana y con su intento de recuperar con la poesía -como bien entendía Pascal- la naturaleza perdida. 
Algunos, igualmente, han identificado a Martí con el Romanticismo, o con el postromanticismo. Ciertamente hay rasgos románticos en el ser-escritura martiano: el interés en lo popular, el espíritu de absoluta libertad y trascendencia que anima a los poetas, (sobre todo los alemanes con quienes se identifica más que con los españoles), la vuelta a la tradición y a la naturaleza. ¿Es por eso Martí un escritor romántico? Pudiera serlo. Pero asimismo su espíritu nada tiene que ver con el individualismo, con la exacerbación del yo que caracteriza esa estética. El yo martiano es un yo coral, fraternal. La idea cardinal de la estética martiana es que la poesía es obra de todos, y de que el genio va pasando de individual a colectivo y eso no está en el horizonte de la estética romántica. Lo mismo podríamos decir de lo clásico antiguo. Hay en la oratoria martiana algo de Cicerón y en sus sentencias anima el espíritu de Heráclito. Es evidente que él siente afinidad con la poesía griega, tanto la lírica como la épica y por la oratoria romana. En sus páginas abundan las alusiones a la mitología griega y a la tradición bíblica. El título de su primer libro de poemas -ese por el cual comenzaron a vincularlo con el modernismo- lleva incluso un título que remeda el nombre de un personaje bíblico. ¿Es por eso Martí un clásico antiguo? Pudiera serlo. Si embargo en él hay una distancia de las concepciones aristocráticas del mundo helenístico, del militarismo espartano, del imperialismo romano, el dualismo platónico y del racionalismo que entra en la filosofía con las figuras de Sócrates y Aristóteles. En su pensamiento anima con mayor fuerza el espíritu del paganismo -que según Levinas es el arraigo, en contraposición a la razón que es desarraigo-, ese mundo que mantenía en armonía y equilibrio la esfera. Como ya explicamos Martí también adelanta la escritura de las vanguardias. Ello es fácilmente demostrable y cito ejemplos de ello más adelante. ¿Es por eso Martí un escritor 
vanguardista? Creo que eso escandalizaría a los críticos ortodoxos. Sin embargo la visión optimista martiana y su vida para la ética supera la visión nihilista de la vida que caracteriza la vanguardia, ese sentido de angustia que la posee al no poder escapar el solipsismo propio de su tradición y no saber conciliar la realidad con las contradicciones aparentes en que han sumido la vida las ideologías políticas, religiosas o económicas desde la Ilustración.

Lo anterior explica su modo revolucionario de pensar y su modo ecléctico de ser, dos características que lo impulsan a rebelarse contra las limitaciones de toda normativa, sean géneros literarios, categorías ideo-estéticas o filosóficas. Ese es el motivo que lo lleva a escoger el periodismo para realizar su obra, al darse cuenta que era el medio ideal para llegar a un mayor público con la celeridad que los tiempos demandaban y con libertad. Después de haber leído en el libro de los tiempos, de las diversas culturas humanas y sus civilizaciones; después de haber indagado en los más profundos secretos del alma humana ve que el hombre es uno y el mismo en todas partes. La cultura enciclopédica que adquiere determina su disentimiento con los estatutos ontológicos y epistemológicos que el poder y la razón de su tradición instauraron en el tejido social de la historia occidental desde Grecia. Basta echar una ojeada al vuelo a los temas que tocó con su pluma para constatar que nada humano le fue extraño, y que su periplo intelectual se dilata en un inmenso paisaje que es a la vez esencia y resumen de todo lo que le antecede y le sucede. En realidad podemos afirmar para mayor justicia que Martí es un filosofo sin filosofia, un pensador sin escuela definida, sin ontología, un poeta sin escuela que usa la poesía para penetrar las leyes físicas y espirituales del mundo que lo habita y que él expande con esa psicología prodigiosa por esa "capacidad -de la poesía- para 
ensanchar los límites del psiquismo humano" ${ }^{15}$ y con su temperamento amoroso que tiñe todo su gesto y todas sus huellas. En resumen podemos decir que su escritura ética es su filosofia, o mejor aún, su metafísica, que es -como Levinas sabiamente ha demostradoanterior a la filosofía.

Ahora bien si comprendemos que en Martí en vez de una literatura -que es epocal y normativa-, hay una escritura ecléctica que trasciende por su esencia ética, entonces será más fácil abandonar de una vez por todas el intento de colocar a Martí dentro del modernismo. Si esto no fuera suficiente y fuéramos a considerar que Martí más que un escritor, es un pensador que tuvo la gracia de ser poeta, entonces aceptaríamos que no le hacemos ningún favor si lo limitamos a un movimiento, una época o una concepción estética, porque los pensadores de talla universal no se les ubica en márgenes tan estrechos que ellos desbordan en todas las medidas posibles. Martí nos ha dejado la tarea de descifrar el caudal de sabiduría que dejó en su palabra y en esa dirección vamos, aunque el trecho por andar es aún inmenso. Pero hoy es más que evidente que cuando pensamos en Martí debemos verlo en ese "arte de las distancias como llamó a su poética" y en una claridad que nada tiene que ver con ideologías, ni filosofías, ni religiones y, mucho menos, escuelas literarias. Si hay una lección que nos quiso legar como es que el hombre es el mismo más allá de las categorías de tiempo y espacio, de construcciones racionales, cualesquiera éstas sean y está más allá del conocimiento de las épocas que muchas veces lo que hacen es deshumanizarlo y fragmentarlo para poderlo despojar de su inteligencia natural y, a la vez, vaciarlo de su dignidad. Su vida entera fue una batalla por restituir esa dignidad a la raza humana que amaba, más allá de cualquier medida lógica o racional. Un saber de esa naturaleza no cabe en clasificaciones de ninguna índole. Si hay 
algo que Martí inaugura es un modo de pensar fuera de la filosofía de la razón que puede constituir -con un estudio serio y profundo- el modo que represente el pensar auténtico latinoamericano. De todas las ideologías de su época habló con reservas. El culto a la personalidad y el mesianismo lo aterraban tanto como la mentalidad colonizada de los hombres de su "América mestiza". La audacia epistémica que refleja el contra-discurso martiano de la modernidad burguesa está en situar la poesía al nivel de la ciencia y por encima de la industria. Es decir, iguala su epistemología con el discurso más prestigiado por el poder del estado moderno -la ciencia- y dice que éste, cuando termine su ciclo, volverá a la poesía a la que pone por encima de la teleología del desarrollo progresista. Al hablar de la ciencia dice que cuando su ciclo haya concluido y sepa cuanto hay que saber, no sabrá más de lo que sabe el espíritu hoy. Lo que realmente le debemos agradecer a los pensadores que son capaces de echar abajo las vallas de los sistemas y las estructuras que encarcelan el espíritu humano es, precisamente, que sus proposiciones nieguen los límites y las fronteras que establece el poder y adelanten, con su modo revolucionario de pensar, épocas nuevas. Esa es la gran virtud de una escritura ética; el constituirse en el último bastión de defensa de la justicia humana.

\section{Rasgos constitutivos de su escritura.}

La primera impresión que recibe un lector que penetra en la escritura martiana es la de estar en presencia de una palabra cuyo horizonte no es aprehensible en su totalidad, siente como que algo se le escapa, que se desliza hacia un lugar no visible. Se tiene la sensación de que su signo se expande, se espesa y desciende a una corriente subterránea donde están las ideas latentes que, según Foucault se revelan y esconden a la vez. 
Mientras más avanzamos en su lectura, su palabra se va haciendo más problemática, como si se llenara literalmente de voces que hablaran distinta lengua, a ratos clásica, a ratos barroca, a ratos romántica, a ratos moderna y a ratos postmoderna. Sus jeroglíficos -que hay que seguir con cuidado para no perderse, como le ocurría a Gutiérrez Nájeravan hacia los bajos fondos, a esas profundidades donde se conectan con la raíz, con el sentido límite. Es tan importante para él llegar a la raíz que se convierte en un explorador subterráneo de oficio: "Hombre es quien estudia las raíces de las cosas, lo demás es rebaño" (II, 377) ${ }^{16}$ y "Radical no es más que eso; el que va a las raíces. No se llame radical quien no vea las cosas en su fondo. Ni hombre a quien no ayude a la seguridad y dicha de los demás hombres" (II, 380). Los caracteres que aquí se resumen son los siguientes: Uno, su palabra va siempre a la raíz, a ese espacio que Foucault llama los “arriere-pensées', los fondos, trasfondos y 'bajos fondos" ${ }^{17}$. Dos, su palabra no es dada sino desde y para la justicia y la verdad. Es decir, no es una escritura comprometida ni con las modas, ni con las normas. En su radicalidad comenzará a interrogar al lenguaje y hablará desde el ser del lenguaje, o sea, desde una perspectiva arqueológica y metafórica. ¿YY cómo aprehender ese ser del lenguaje, se pregunta Foucault? Es esto lo que hacen los poetas" 18 . Como intérprete desciende y se convierte "el buen excavador de los bajos fondos"19. Por eso considero que Darío representa una literatura, mientras que Martí representa una escritura, es decir, es un autor sin literatura, como apuntamos antes. $\mathrm{Al}$ situar su logos más allá y más acá de los límites histórico-sociales del mundo moderno, elige un ethos en que se.aparta de la literatura y crea un signo en el trasfondo del mito y de la metáfora que es a un tiempo modelador y reflejo su ser ético. Ese ser ético que produce una escritura ética no puede establecer otro compromiso que no sea con el bien y 
la verdad porque lo que busca es la transferencia hacia una alteridad incondicional en un acto sagrado de solidaridad humana, de apertura a la heterogeneidad que despliega ante los ojos del poeta el arcoiris del hombre.

Para fundamentar mejor los rasgos de su escritura utilizaremos algunos de los conceptos de Michel Foucault y Roland Barthes pues ellos sintetiza una buena parte de lo que la teoría contemporánea ha podido develar sobre la complejidad del lenguaje con relación al signo, la palabra, el estilo, la escritura. Estas ideas proporcionan herramientas epistémicas que nos ayudan a alumbrar mejor el carácter polivalente del signo martiano, las zonas menos visibles y exploradas. Hacia finales del siglo XIX con el advenimiento del pensamiento de Nietzsche, Freud y Marx la episteme clásica sufre un duro golpe y se abre un espacio en el que el lenguaje comienza a ocupar un lugar privilegiado. En otras palabras, comienza a rivalizar con el antropocentrismo, algo que estaba ya en el poeta cubano, como veremos. En ese lugar privilegiado

el lenguaje se encuentra consigo mismo -un lenguaje autoreferencial, autoalusivo, verdadero 'lenguaje-objeto' que se presenta como presencia pura, ensimismada en el acto fundacional de una escritura. Es, en efecto, el concepto de escritura el que gobierna esa vasta reconstrucción aparentemente arqueológica $-\mathrm{y}$ que esconde en el fondo una de esas filosofias de la historia a las que Althusser denomina de futuro anterior ${ }^{20}$.

Esta peculiaridad del lenguaje develado como arqueología, consciente de la eficacia de sus herramientas para escarbar, hacer cortes, penetrar los sistemas estratificados es uno de los rasgos distintivos de la escritura martiana. De ahí que titulemos este capítulo precisamente "Para una arqueología de la escritura martiana". A lo largo de nuestra disertación hay varios momentos en que tocamos la peculiaridad del lenguaje en Martí, 
refiriéndonos a su comportamiento, la manera en que él habla con el lenguaje y desde el lenguaje, en que encarna en la escritura. Y es de esperar que así sea con un pensador que está tocando la raíz, llegando al magma del mundo real donde se tropieza con el lenguaje desnudo, descolonizado, limpio ya de las impurezas de los sistemas. En tal sentido el ser martiano supo registrar muy temprano que se avecinaba un cambio del pensar desde el lenguaje y que éste volvía de las cosas, es decir, tomaba distancia de las cosas. Según Foucault esto es:

Un proceso nuevo, inédito, en el que la dualidad de palabras y cosas, o de lenguaje y referente queda abolida, instaurándose un lenguaje que no representa al ser, o que ya no transcribe su interioridad, sino que él mismo es el ser: un lenguaje al fin pleno que no representa o representa nada más que a sí mismo; pura presencia de sí mismo, autoreferido, autónomo. Tal es el lenguaje de una escritura que sucedería a una literatura al fin abolida. (17)

Esta literatura abolida sería el resultado de una instauración de la escritura ética como paradigma del ser y del acontecer de la humanidad, una escritura que hiciera estallar el discurso político para devolver al hombre su dimensión real desde y para la verdad. Sería la escritura registrando la trascendencia del hombre en el instante de la eternidad en ese futuro anterior que menciona Foucault a partir de Altusser y que también menciona Cintio Vitier cuando en "Martí futuro" analiza el estilo martiano, que tendremos tiempo de valorar más adelante. A propósito de lo que acabamos de referir -y como constancia de la diferencia literatura/escritura que establecemos, Vitier escribe lo siguiente:

No fueron las palabras para Martí ni fines en sí mismas ni meros medios. $\mathrm{Ni}$ las ve como el arte-purista u orfebre sin alma, ni tampoco como signos huecos, vacíos de realidad, meros vehículos de una idea y a su solo servicio. No es la escisión académica idea-cosa, palabra-cosa sino, como 
bien viera Darío, el milagro de su identidad poética, de la criatura viva: $E t$ Verbum erat Deus. $(207)^{21}$

Y añade que si quiere presentar esta esencia de la palabra martiana es porque Martí tiene un "tono" que es inconfundible y que en su palabra más que ideas lo que hay es pensamiento viviente, y un "pathos cordial que da siempre tono y color a su palabra" (208). Estas ideas de Vitier sobre el lenguaje y las palabras coinciden plenamente con las citadas de Foucault. Por su parte Barthes plantea que hacia 1850 “el escritor dejó de ser testigo universal para transformarse en una conciencia infeliz" (12). ${ }^{22}$ A partir de ese momento debió elegir su escritura, o en el pasado, o contra éste. Desde Flaubert la Literatura "se ha transformado en una problemática del lenguaje" (13). Hasta el clasicismo el signo no tenía espesor, era más bien decorativo, transparente, pero hacia "fines del siglo XVIII comenzó a enturbiarse, la forma literaria desarrolla un poder segundo [...] fascina, desarraiga, encanta, tiene peso" (13). La Literatura será portadora desde ese momento de un "lenguaje consistente, profundo, lleno de secretos, dado a la vez como sueño y como amenaza" (13). Esa ruptura de la unidad clásica que produce la doble constitución de la Literatura moderna, como forma y como objeto es lo que el escritor tendrá que enfrentar. "Desde hace cien años, toda escritura es un ejercicio de domesticación o de repulsión frente a esa Forma-Objeto que el escritor encuentra fatalmente en su camino, que necesita mirar, afrontar, asumir, y que nunca puede destruir sin destruirse a sí mismo" (13-14). Unos, como Chateaubriand se dieron a la "euforia del lenguaje, especie de narcisismo donde la escritura se separa apenas de su función instrumental y sólo se mira a sí misma" (14). Otros como Flaubert desarrollan la literatura como objeto, en la fórmula valor-trabajo, es decir, el producto debía ser una 
joya. En el caso de Mallarmé encaminó su esfuerzo "sobre la aniquilación del lenguaje cuyo cadáver, en alguna medida, es la Literatura" (14). Estos procesos encuentran en su reverso las expresiones ideológicas y estéticas que inaugura la Ilustración al jerarquizar conceptos disolventes de valores esenciales de la representación artística -el concepto del tiempo y de la belleza, por ejemplo- que son sustituidos por valores de cambio, asociados con la mercantilización de la vida moderna.

La lengua que el escritor recibe en herencia es un objeto delimitado, cercado por rituales de verdad "fuera del cual, solamente comienza a depositarse la densidad de un verbo solitario" (17). Salir de esa zona de confort y familiaridad que la lengua ofrece con el paisaje de toda la literatura y toda la historia como telón de fondo, es una osadía, una especie de heroicidad, o un salto al vacío pues la elección de un signo diferente significa perderse en una lejanía que quizás el cuerpo social no alcance a descifrar. Es, lo que sugiere Gastón Baquero nos sucede a los cubanos con Martí, que se nos fue a vivir demasiado lejos. El estilo constituye el vehículo que puede perforar esa zona límite de la lengua pues en él se inscriben "imágenes, elocución, léxico" como expresiones corporales que vienen "del pasado del escritor y poco a poco se transforman en los automatismos de su arte" (18). En el estilo de un escritor aflora "un lenguaje autárquico que se hunde en la mitología personal y secreta del autor, en esa hipofísica de la palabra [...] donde se instalan de una vez por todas, los grandes temas verbales de su existencia" (18). Es por eso que el estilo martiano es un organismo poderoso, inconfundible y magnético que tanto asombro a escritores como Darío, Unamuno, Gutiérrez Nájera, Mistral, Lezama, Juan Ramón Jiménez, -para citar sólo unos pocos ejemplos- quienes se sintieron tocados por esa lengua de lava. Es decir, Martí desarrolla un estilo tan original 
en su escritura que una vez que el lector entra en ella siente una atracción, un palpitar que a la vez que seduce y embriaga, exige concentración para no extraviarse en sus extensos períodos o en la altura a las que se remontan sus ideas.

En esta definición Barthes describe las conexiones que un escritor pude establecer con esas zonas del subconsciente de donde mana el verbo espeso que se transfigura en imágenes que, en el caso de Martí, el sentía brotar desde lo hondo de su ser como magma que él solamente copiaba: "Tajos son estos de mis propias entrañas, mis guerreros. Ninguno me ha salido recalentado, artificioso, recompuesto, de la mente; sino como las lágrimas salen de los ojos y la sangre sale a borbotones de la herida" ${ }^{23}$. Para Barthes el estilo "es como la dimensión vertical del pensamiento. Sus referencias se hallan en el nivel de una biología o de un pasado, no de una Historia: es la "cosa" del escritor, su esplendor y su prisión, su soledad" (19). Yo añadiría que es su casa, su morada por excelencia y no depende de la Literatura. "Es la parte privada del ritual, se eleva a partir de las profundidades míticas del escritor..." (19). En esta última frase de Barthes está la clave de lo que decimos sobre la mito-poética martiana. El estilo es una necesidad que se conecta con regiones de los profundos substratos del ser, donde está ese límite que la palabra no puede cruzar sin deshacerse, porque tiene "una estructura horizontal" y en ella "todo está ofrecido, destinado a un inmediato desgaste..." (19). Sin embargo "el estilo es una dimensión vertical, se hunde en el recuerdo cerrado de la persona [...] el estilo no es sino metáfora" (20). La escritura martiana viene a ser una ejemplificación muy apropiada de los conceptos de Barthes y brinda un singular acercamiento a una de sus grandes metáforas: de la raíz al ala. Es la verticalidad que va desde los trasfondos hasta la rama del árbol -imagen sagrada en él- o "la estrella que ilumina y mata", imagen 
trascendente. Esta verticalidad se da muy particularmente, -diría con especial fuerza- en su poemario Flores del destierro, libro en el cual la mayoría de las imágenes siguen esa trayectoria. Coincido con el crítico francés en que el estilo es metáfora y que esa metáfora es todo lo que no es visible del ser, o todo lo que se desliza fuera de la teleología racional, fuera del conocer. De modo que el estilo se ofrece como una sorpresa y es portador de un misterio que la poiesis sabe aprehender y testificar. El lenguaje no puede descifrar todo el manantial que yace en el estilo; por eso debe transformarse en metáfora, debe espesarse, desligarse de la doxa. Sólo así alcanza a alumbrar las zonas profundas del estilo.

Hay una frase de Martí que sintetiza todo lo que Barthes ha querido explicar con relación al estilo. Dice Martí con su acostumbrado poder de síntesis metafórico: "El estilo es el hombre". De esta manera el estilo viene a ser "una suerte de operación supraliteraria, que arrastra al hombre hasta el umbral del poder y la magia. Por en su origen biológico el estilo se sitúa fuera del arte, es decir, fuera del pacto que liga al escritor con la sociedad" (20). Esta expresión del ser en un estilo, ligado a una lengua que hereda "le impone al escritor como un Frescor por encima de la Historia" (21). La horizontalidad de la lengua y la verticalidad del estilo señalan para el escritor "una Naturaleza, ya que no elige ni el uno ni el otro. La lengua funciona como una negatividad, el límite inicial de lo posible, el estilo una Necesidad que anuda el humor del escritor con su lenguaje" (21). En la lengua tiene la familiaridad de la historia, en el estilo su pasado. Pero -concluye Barthes- "toda forma es también valor; por lo que, entre la lengua y el estilo, hay espacio para otra realidad formal: la escritura" (21).

Sin embargo, cuando el escritor elige un tono, un ethos se individualiza más allá del lenguaje y del estilo, asume una responsabilidad con la cual quiebra las leyes de la 
normativa para instaurar una escritura portadora de "un signo total, elección de un comportamiento humano, afirmación de cierto bien [...] Lengua y estilo son fuerzas ciegas; la escritura es un acto de solidaridad histórica" (22). Yo diría más, diría que la escritura es un acto de responsabilidad y de solidaridad humana y una forma de poetización de la fraternidad. Eso es lo que hace Martí cuando se para frente a la literatura de su época y ve las veleidades, el juego de máscaras, el coqueteo con el poder, la angustia existencial de los escritores y artistas expresada en el lamento y la evasión y comprende que su elección irá más allá de las fuerzas ciegas de la lengua y el estilo. Elige entonces su escritura, que será ética por su temperamento y carácter y que moldeará toda su creación. "Colocada en el centro de la problemática literaria, que sólo comienza en ella, la escritura es por lo tanto esencialmente la moral de la forma, la elección del área social en el seno de la cual el escritor decide situar la Naturaleza de su lenguaje" (23). Esto explica por qué Martí elige la ética para situar la naturaleza de su lenguaje y por qué, a su vez, su lenguaje está saturado de naturaleza pues para él también ésta es ética. Es decir, a partir del momento en que un escritor decide inaugurar una escritura en el horizonte de su lengua establece un compromiso social y humano, establece una eticidad, y desde entonces, su escritura será el reflejo de su acontecer, lo mismo que su acontecer prefigurará su escritura.

El compromiso que entraña la elección de una escritura, en tanto enfrenta al escritor con su sociedad, establece cierta tragicidad ya que su lengua no se ofrece como un instrumento eficaz y hecho que le permita establecer su verdad. El escritor deberá modelar en su fragua ese lenguaje con los mejores materiales de su mundo personal a modo de una herramienta resistente y precisa. Pero la libertad que tiene para hacerlo no 
es la misma en toda época. "Al escritor no le está dado elegir la escritura en una especie de arsenal intemporal de formas literarias" (24). Deberá luchar con la historia y la tradición y conjurar, de la mejor manera que pueda, esos remanentes que éstos dejan en el lenguaje, esa memoria que permanece en las palabras como huella del pasado aunque su presente le haya asignado nuevos significados. De manera que la escritura deberá establecer su verdad a partir de una libertad mediatizada por los escombros, las ruinas del signo. La precariedad de éste vuelve la escritura hacia el símbolo, hacia esas zonas secretas del lenguaje donde palpitan las esencias, en una especie de casa de espejos, o la casa de la metáfora. Aquí la palabra establece su esfera, se constituye un prestigio, una resistencia a los metarrelatos y sus excesos. El espacio que abre la escritura ética se constituye en una esfera de aleatoriedad donde el binomio poder / saber entra en crisis, donde se desenmascara su ineficacia y puede ser pulverizado por la crítica. Sólo la escritura ética pudo deshacer la unidad discursiva que la burguesía de la época monárquica y la post-revolucionaria elaboraron con su vocación universalista y sus ansias hegemónicas.

Ahora bien, siendo Martí un ser reconstruido con los materiales de sus propias entrañas y "reconquistado para sí", es decir, liberado de toda la carga perniciosa que la sociedad ha vertido en él con sus sistemas coloniales, construye su lenguaje para la verdad y la libertad de donde emerge fulgurante su escritura ética. El ejercicio del criterio es ejercido por él desde la raíz, desde el fondo oscuro de la naturaleza del ser, dentro de la naturaleza del mundo y con las herramientas de su poética. Desde la luminosidad de la metáfora, que es el lenguaje privilegiado de la ética, Martí transgrede literalmente las fronteras del espacio y del tiempo. De este modo va evolucionando -por su ley del 
incesante movimiento- desde una literatura que al principio es reflejo de los modos y las modas de su lengua que ya se habían calcificado, a la asimilación de las técnicas de las escuelas europeas, hasta comenzar, hacia 1875 a conformar su estilo que se asoma ya en El presidio político en Cuba de sus 17 años. De regreso a América y a partir de 1880 da inicio a una nueva etapa en su creación. Entra en contacto, primero, con el pensamiento de Emerson y la poesía de Whitman y comprende que ese modo de filosofar desde la naturaleza del primero y ese poetizar apotégmico y telúrico del segundo se avienen con la índole de su carácter y su temperamento. De modo que los lee con el rigor que merecen y lo que absorbe del trascendentalismo norteamericano se mezcla con los sedimentos que ya hay depositados en su fragua. Igualmente comienza en esta etapa su arqueología de las tradiciones aborígenes americanas que subyacen en el trasfondo de las nuevas repúblicas del sur y del vertiginoso acontecer de la sociedad estadounidense que vive un acelerado proceso de transformaciones en todos los órdenes de la vida. Desde 1880 hasta 1895 reside, por decirlo de alguna forma, en el torbellino de la modernidad, en el centro de la ciudad arquetípica del mundo moderno, Nueva York, desde donde continúa absorbiendo todo el acontecer de la vieja Europa y muy cerca geográficamente a la vida tradicional y autóctona de sus queridas "patrias azules" a las que visita y donde absorbe la dimensión mito-poética del hombre natural. Por otro lado continúa en su estudio y asimilación del saber de las culturas orientales por las cuales siente especial afinidad, sobre todo de su filosofía. Así funde en su ideario tres universos lejanos, tres tipos distintos de seres humanos, tres cosmovisiones del mundo y de la vida, tres tradiciones culturales. De esta síntesis -en la base de la cual está el substrato de su cubanía junto al legado filosófico y cultural del Oriente y del Occidente- nace su cosmovisión y su escritura ética como un 
diamante que se va puliendo al ritmo intenso en que transcurre su vida y con un estilo y en ethos poético inconfundible.

\section{Instancias contra-discursivas y paradigmáticas de su escritura ética}

La primera instancia en el ejercicio pleno de su escritura ética lo constituye su contra-discurso de la modernidad estética. Se muestra implacable en su crítica de las veleidades, el diletantismo y el dandismo de las instituciones literarias de la modernidad. Comienza con las escuelas europeas a las cuales critica por su excesiva preocupación formal y sus malabarismos lingüísticos que él sabe tienen un límite y conducen, inevitablemente, a un callejón sin salida. Las consecuencias de esta crisis las analizo con más detalle en el capítulo dedicado a la modernidad estética. Baste decir ahora que Martí supo ver que el cuidado excesivo de la forma en detrimento del fondo acarrearían, a la postre, un agotamiento y un límite puesto que si el arte es reflejo de la realidad, o la recreación de una segunda naturaleza o un examen de los problemas vitales del ser en el mundo, entonces las preocupaciones humanas, espirituales y éticas deben estar en el centro del acto creativo. Parte del criterio de que toda revolución en la forma debe ser acompañada de una revolución en las esencias, de lo contrario se convierte en un arte de lentejuelas. El artista, más que un orfebre, debe ser un sacerdote o un profeta, el anunciador de la buena nueva, el testigo de lo que se aproxima, del momento de la eternidad del instante sublime de la verdad, o como lo llamaba Joyce, "de la epifanía".

Como en toda regla, aquí también hay sus excepciones y a los artistas que asumen la verticalidad y el compromiso con la verdad los elogia con fervor pues era pródigo, más 
que en la crítica, en el elogio. La literatura latinoamericana tampoco escapa su crítica, sobre todo el encartonamiento estilístico de los "catedráticos momias" como él suele llamarles, así como la copia excesiva por parte de los jóvenes escritores de las escuelas europeas. Martí era enemigo visceral del mimetismo en literatura y de la contaminación del idioma con excesivos términos extranjeros. En este caso insta a los modernistas de América a mirar las bellezas de la naturaleza americana y las páginas brillantes de su historia, a la solidez y belleza de sus tradiciones. Esta crítica incluye también la entidad pues el mal de la copia, del calco, de la seducción por todo lo extranjero lo ve como uno de los grandes males que el colonialismo ha dejado en los pueblos del continente. La conciencia que hay en él de que la tarea de descolonizar el pensamiento era tan importante como descolonizar el espacio geopolítico es de vital importancia en su estrategia cultural. La mayoría de sus documentos programáticos van encaminados a crear una conciencia en el continente de amor a lo propio, de admiración por lo autóctono, de la belleza de las tradiciones del "hombre natural" de América, a quien coloca por encima del "criollo exótico". Hay toda una estrategia discursiva digna de estudiar en detalle -nuestro vino, nuestro Homero, nuestra Grecia- acerca de cada una de las ideas arquetipicas que introduce en el discurso americanista destinadas a extirpar ese sentimiento de rechazo por lo autóctono y la admiración excesiva de lo foráneo.

La originalidad de su contra-discurso de la modernidad estética está en que él marcha a contracorriente de ésta. La estética moderna se funda en un relativismo histórico cuya presencia se ejerce como crítica de la tradición. Para ellos el arte del pasado está fijo en normas y modelos que hay que superar, o mejor, que hay que enterrar. Los clásicos no son ya los hombros donde se sube el artista moderno para imitar a sus 
modelos. Ahora el artista es el creador de su propio pasado, modificable, adaptable y privado. Es decir, la modernidad estética introduce un cambio sustancial en el ideal de belleza como valor eterno que había perdurado desde la antigüedad y lo sustituye por uno temporal, que cambia constantemente y que da origen a la nociva idea de la belleza instantánea. Martí nunca rompe con la tradición, no comete ese fratricidio cultural. Para un escritor cuya cosmovisión tiene raíces tan hondas en el pasado -y que sabe que vive un período de crisis- romper con la tradición es un lento suicidio, es desconectar las raíces y el tronco del árbol y dejar sólo las ramas. Es afirmar que la humanidad hasta ese momento no ha logrado producir ninguna aleación durable, válida, permanente y que hoy somos más sabios y creadores que ayer. O creer que el arte del presente ha salido de una lámpara maravillosa que alguien frotó en París y se hizo la luz. Martí rechaza tal mentalidad porque sabe que es el producto de lo que llama en "Nuestra América" la "falsa erudición" y las "contradicciones aparentes". Cuando contempla el "ejército de enmascarados en que se convertido la tierra", no puede aceptar que el presente, más alejado de la naturaleza que en ninguna etapa anterior de la historia -a la que primero convierte en taller y más tarde en basurero de desechos tóxicos- que se haya sustituido el sentimiento por la razón y convertido la obra de arte en objeto de lujo -desechable por demás- pueda ser mejor que el pasado de la tradición. Y ese viaje que emprende contrario a la modernidad estética, moviéndose hacia el pasado con su escritura arqueológica es el primer instante del paradigma de su escritura ética. Ahora bien este viaje del poeta cubano al pasado no tiene las connotaciones ideológicas de la Ilustración, no es el viaje al Dorado o al encuentro del buen salvaje de Rousseau. Si algo no hay en Martí es el escape clásico del artista moderno que no es capaz de entender las 
complejidades del presente o le es imposible discernir los ídolos muertos y las vallas caídas. Por el contrario, es un hombre de su tiempo e incluso está por encima de su tiempo. Es un intelectual que ha hecho un retrato, doloroso, pero lleno de amor y de poesía sobre la agonía del hombre moderno en su ensayo arquetípico El prólogo al poema del Niágara. En ello radica una de las originalidades de su viaje arqueológico. Lo que busca en el pasado son los instantes en que la humanidad ha sabido curar sus propias llagas más allá del cielo o el infierno, más bien en la sabia de la naturaleza.

De manera que esta primera instancia se nos revela como paradigma doblemente: primero porque viaja contrario a los escritores modernos que van disparados al futuro a embriagarse con los automatismos y "los cachivaches relucientes" del progreso, mientras que él va al pasado de la tradición aborigen del "hombre natural" a despertar sus voces mágicas, y embriagarse con sus cantos litúrgicos y segundo porque la savia donde se nutre su escritura está en la naturaleza y es ella misma naturaleza. Su tiempo predilecto no está en la historia, no está en la ciencia y su deformada idea de infalibilidad, está en el mito, en la metáfora, en el símbolo y éstos trascienden el tiempo histórico. "Hay que tener la audacia de ver ese 'equilibrio del mundo' en correspondencia con la 'justicia de la naturaleza' [y] el valor intelectual de comprender que para Martí historia y naturaleza [...] tenían que ser llevados a un ajuste, a una comunión, y que este era el fin último de su poesía. ${ }^{24}$ Sin embargo hay aún otra instancia en que su escritura va en sentido contrario al de la modernidad estética y es en la sublimación que ésta hace de la creación individual, del genio individual. Para Martí la creación artística es obra colectiva por lo cual dirá que la poesía es de todos y que tan autores son de ella quienes la escriben como quienes la disfrutan. Estamos frente a dos de las audacias epistémicas martianas. Una, que la poesía 
está en la naturaleza, dos que la poesía es obra de todos. Es decir a la apología de la individualidad creadora del artista moderno, a la actitud del pavo real que se vanagloria de sus páginas inmortales, ese yo arrellanado en su torre de marfil, opone la voz del nosotros, de la creación colectiva, la poesía coral del espíritu humano en el seno de la naturaleza.

Tales desbordes de la escritura martiana de la episteme de la modernidad estética, desbordándola en cualquier dirección, hace un tanto problemática la idea de considerar una modernidad dentro de la modernidad -como sugiere Habermas -donde anclar su escritura subversiva. Porque si valoramos que la crítica martiana a la modernidad es de la misma índole que la de Nietzsche, es decir, como una época de crisis, tal y como demuestra en el Prólogo al poema del Niágara, en El poeta Walt Whitman, y en "Nuestra América", documentos paradigmáticos de su pluma, entonces una modernidad alternativa significaría para él aceptar ciertos postulados estéticos de la modernidad con los cuales no comulga. Para él la modernidad es una etapa de la historia que hay que superar y por eso propone un "orbe nuevo", un mundo para la ética que no tiene espacio para una época que se niega a sí misma. Pero sobre todo Martí demuestra que la suya es una subjetividad que disiente de la del individualismo burgués que establece el enriquecimiento material como brújula y como meta de la existencia, que se complace en la fama, la gloria y el aplauso de los púlpitos. Martí, por el contrario huye de tales posturas. Por ejemplo en su poema "Académica" dice que quiere sacar al verso de los salones y llevarlo a las frondas, a los valles, a que cabalgue en la desmesura. En otro poema dice "Contra el verso retórico y ornado, el verso natural", y en Versos sencillos "Con los pobres de la tierra / quiero yo mi suerte echar / El arrollo de la sierra / Me complace más que el mar" (III, 238). 
O sea su lugar es con el verso natural y el hombre natural, sencillo, humilde, el que se satisface en la comunión, en la hermandad, en el amor incondicional al prójimo, en sentarse a la mesa de los humildes y eso nada tiene que ver con la pompa y el glamour de la ciudad, de la que quiere escaparse todo el tiempo, de la "urbe antiática" que lo consume y desequilibra. Y por si fuera poco, nada tiene que ver con el empresario triunfador que le parece un hombre carente de dignidad. Otra estrofa de Versos sencillos dice: "Denle al vano el oro tierno/ Que arde y brilla en el crisol: / A mí denme el bosque eterno / Cuando rompe en él el sol". ${ }^{25}$ El tipo martiano es la encarnación sublimada de la sustancia ética, la otra cara del utilitarista pragmático. Gabriela Mistral, quien tan bien lo leyó dice, como resumen de estas ideas: "Se hablará siempre de él como de un caso moral, -léase ético-y su caso literario lo pondremos como una consecuencia". ${ }^{26}$

La segunda instancia la constituye la modernidad burguesa. Ésta es una de las más intensas y consumidoras de todas las tareas que ocuparon su breve e intensa vida. $\mathrm{Su}$ escritura ética se para aquí frente al "monstruo frío" de Nietzsche, pero con la peculiaridad de estar en el vientre de la ballena, es decir, -para usar sus propias palabrasen "las entrañas del monstruo". Desde esas entrañas emprende una de las labores arqueológicas y deconstructivas más eficaces que escritor hispanoamericano alguno haya emprendido para explicar todas las capas del gran edificio de la modernidad burguesa construido en Norteamérica. Con su pluma y a través una decena de diarios de todo el continente desata una labor de cronista en la cual mezcla todo el arsenal de conocimientos de que disponía en los campos de la psicología, la sociología, la jurisprudencia, la historiografía, la arqueología, la filosofía, la ciencia y la política, la cultura y el arte y con su asombrosa capacidad de observación y de síntesis, deja un 
conjunto de textos que aún hoy asombran por el grado de penetración que alcanzan y por la vitalidad y actualidad que conservan.

No hay asunto de la vida del país que no haya quedado reflejado en estas crónicas norteamericanas, siempre desde la perspectiva del hombre marginal, o desde la mirada del pensador fronterizo de que habla Walter D. Mignolo en su ensayo "Colonialidad global, capitalismo y hegemonía epistémica". ${ }^{27}$ En dicho ensayo Mignolo escriben: "Esto es, la exterioridad como el afuera construido desde el adentro [...] El pensamiento desde la exterioridad es pensamiento fronterizo y abre las posibilidades a la 'diversidad', o a la diversidad como proyecto universal, epistémico, ético, político, económico" (79). En este pensamiento queda resumido el contra-discurso martiano de la modernidad burguesa en sus diversas vertientes: como discurso anticolonial, como discurso antiimperialista, como proyecto de alteridad, es decir como heterogeneidad discursiva donde se constituye su proyecto ético-poético. En esta exterioridad construida desde dentro, pero que apunta hacia una episteme fronteriza, que piensa el exterior de la modernidad desde su interior, radica el paradigma de su escritura ética en esta segunda instancia. En esta escritura aparece la sociedad con sus diferentes clases muy bien diferenciadas. Por un lado los ricos ahitos y mofletudos" en sus palacios de oro y por el otro los pobres y enclenques hijos de los trabajadores sumergidos en el albañal; los partidos políticos que se compran los botos y se venden al mejor postor, los políticos que van por la calle cubriéndose el rostro para que no se les vean las llagas de la corrupción; las grandes figuras políticas o culturales que dan nombre al país; el sufrimiento de los negros esclavizados y vejados por el color de su piel; los indígenas desplazados de sus territorios y confinados en corrales donde se marchitan de vergüenza; las celebraciones populares; los logros industriales; las 
proezas arquitectónicas; el crecimiento desmedido de los monopolios que terminan exacerbando las ambiciones imperiales del país; los contubernios y tratados onerosos que se elucubran de espaldas al pueblo para satisfacción de los poderosos. Es un cuadro que, salvando las distancias, podría compararse a "La comedia humana" de Balzac. Ahora bien, la cronística martiana por ser una arqueología no se detiene en el acontecimiento, en la anécdota, que más bien es un pretexto. En un plano "Martí narra en forma alegórica una visualización personal del espacio nacional norteamericano, pero, en otro, más profundo y velado, inserta el subtexto de una narración aleccionadora y ética, destinada a los lectores hispanoamericanos". ${ }^{28}$ Es tan absolutamente original y revolucionario en esta labor cronística que lleva a Fina García Marruz a escribir: "Podemos decir, sin temor a exagerar, que cada una de sus crónicas es un universo con leyes propias, cuya clave podría ser la penetración amorosa". ${ }^{29}$

En el contexto de su cronística -que se da precisamente de la forma más viable y operativa que la época podía ofrecer a un escritor interesado en la sociedad, la prensaMartí inserta su narrativa anticolonial y antiimperialista. No es mi propósito extenderme demasiado ahora en estas dos expresiones contra-discursivas de su escritura ética puesto que hacemos referencia a éstos en nuestro capítulo de su contra-discurso de la modernidad burguesa. Pero la visión que Martí tiene de esta modernidad en las postrimerías del siglo XIX es la misma que después aparecerá en la escritura de los más importantes filósofos de inicios del siglo XX, comenzando por Nietzsche quien -al igual que el poeta cubano- ve el progreso como un fracaso pues esto se da a costa del empobrecimiento de la riqueza de la propia vida y porque impone una semejanza que oblitera las formas ricas y diversas de los procesos vitales. La homogenización de la vida 
que el progreso propone deja dos opciones al ser humano: o perder el alma en los engranajes de la maquinaria tecnológica o la auto-inmolación contra la maquinaria del poder, la actitud heroica. Esta es la que adopta Martí desde muy temprano en su vida al decidir que todas sus energías y fuerzas y su talento como escritor serán puestos al servicio de organizar y protagonizar la guerra por él llamada necesaria con la cual poner fin al colonialismo en su patria, pues era la única vía que la metrópoli, en su obcecación de no acceder a la independencia de los cubanos, había dejado para conseguirla.

Foucault tiene un pensamiento con el que retrata a Martí de cuerpo entero. Segú entiende el ser humano debe dejar abierta la posibilidad de ser otro, de "actuar contra su tiempo y, de esa manera, sobre su tiempo y, espero a favor de un tiempo por venir" (3). ${ }^{30}$ Martí actuó contra su tiempo para transformarlo al desacreditar todas las falacias construidas por el discurso euro-céntrico, al darle el tiro de gracia, con su acción revolucionaria, al colonialismo español en América, al describir y pronosticar en su discurso antiimperialista el fenómeno que se fraguaba en el seno del estado monopolista norteamericano y ofrecer a los pueblos latinoamericanos un programa de lucha, una estrategia de contención y de defensa contra el gigante del norte que aguardaba el momento oportuno para entrar en Hispanoamérica a controlar sus economías y mercados. En su carta póstuma a Manuel Mercado escribe: “...ya estoy todos los días en peligro de dar mi vida por mi país, y por mi deber [...] de impedir a tiempo con la independencia de Cuba que se extiendan por la Antillas los Estados Unidos y caigan, con esa fuerza más, sobre nuestras tierras de América". ${ }^{31}$ Trece años antes de ésta le había comunicado su preocupación por la política norteamericana hacia México: "Y en todas las cartas iban filiales iras mías por la avaricia sórdida, artera, temible con que este pueblo mira a 
México: ¡cuántas veces, por no parecer intruso o que quería ganar fama fácil, he dejado la pluma ardiente que me vibraba como lanza de pelea en la mano!". ${ }^{32}$ Queda el testimonio de "Nuestra América", en cuyas páginas aún palpita el ideario de la América nueva, unida, esplendorosa que el soñó. Queda su resistencia a todas las formas directas o disfrazadas de ejercer la violencia territorial y la homogenización cultural -lo que hoy llamamos globalización- por parte de las metrópolis, no sólo porque lo entiende su deber sagrado como creador, sino por su visión holística de la vida y de un mundo que debe conservar, para su propia sobre-vivencia su diversidad, su heterogeneidad, su riqueza de pueblos, lenguas y culturas y porque: "sin esa resistencia al discurso totalizador, esclavizante, no sería posible restaurar prácticas que puedan rescatar a la humanidad de su actual ignominia". ${ }^{33}$

El peor síntoma que Martí ve aflorar como consecuencia de esta fiebre de enriquecimiento en la que el hombre emplea todo el tiempo de su existencia es el empobrecimiento de su mundo espiritual y de su cultura. Bertrand Russell en La conquista de la felicidad habla acerca de la pérdida del interés en el conocimiento de la buena literatura que siendo "universal entre la gente educada hace cincuenta años, está ahora confinada a unos cuantos profesores" (54). En la medida que avanza la modernidad, crece la incultura, sobre todo en los países industrializados donde no creen en la necesidad del ocio pues éste no fomenta el capital y crece al par el sentido pragmático y utilitario de la vida. Esto mismo había observado ya Martí en Estados Unidos y lo plantea en "El poeta Walt Whitman" con particular énfasis, pues es algo que ve deteriorarse con alarmantes consecuencias. El poeta cubano considera que para la sociedad es necesario "la literatura que inculque en el espíritu espantadizo de los hombres 
una convicción tan arraigada de la justicia y belleza definitivas que las penurias y fealdades de la existencia no las descorazonen ni acibaren" (135). Russell cree que esta manera de pensar es herencia del puritanismo inglés que ve la vida como una competencia y por tanto desarrolla más la voluntad que la inteligencia. "Los moralistas puritanos han insistido siempre en la importancia de la voluntad en los tiempos modernos" (55). Este énfasis desarrolló una raza que adoptó "la filosofía de la competencia por ser la más adecuada a su carácter. Sea como fuere, el prodigioso éxito de estos modernos dinosaurios, que como sus prototipos prehistóricos, prefieren el poder a la inteligencia, está dando lugar a que todos los imiten" (55). Luego vaticina que esto se seguirá prolongando por los próximos cien años, pero que el consuelo para quienes no siguen esta moda está en el hecho de que los dinosaurios terminaron extinguiéndose. Recordemos a Martí cuando habla de "Wendell Phillips" quien "creía eficaz y natural la tiranía de la virtud. -Y de estos impulsos movido, solía hablar en hueco ante un pueblo deshabituado a lo absoluto, y que, si se empequeñece en lo futuro, sea cualquiera su grandor visible, será por su amor y práctica a lo concreto" Según Martí este hombre amante febril de la justicia sufría "de ver la vida nacional puesta en el logro de la fortuna" y que todo era "chirriar de ruecas, polvo de comercio y ruido de pesos". Para Phillips dice Martí- "!Franklin os ha corrompido con su economía sórdida del 'pobre Ricardo"! ¡O levantáis el alma, o vendréis tarde o temprano a tierra" (XIII, 68). Hay en este texto una clara crítica al pragmatismo y cierto vaticinio de Martí, similar al de Russell en la cita anterior. El pragmatismo y el utilitarismo tan criticado ácidamente por nuestro poeta han sido la tónica y la brújula de la sociedad norteamericana por los últimos ciento cincuenta años. El paisaje espiritual de la sociedad muestra hoy todas sus grietas y 
erosiones. No me refiero, por supuesto, a la espiritualidad aquí concebida como la creencia en un dios con el que se consuelan las masas en las misas de domingo. Me refiero a la educación para la vida, para la humanidad del ser de la que hablaba Martí, a la estética de la existencia de la que él fue un paradigma. A la vida que no esté delimitada al consumo de bienes materiales y a la evasión de la realidad durante los días de ocio que convierten al ser humano en un objeto más, indiferente, manipulado, agónico.

La tercera instancia o nivel de esta pirámide que es su escritura ética la conforma su discurso de la autoctonía, uno de los fragmentos más hermosos y poéticos de su escritura y el más cercano a su carácter y temperamentos éticos. Es, además, uno de los más hermosos legados de su pluma a la cultura universal puesto que con él, por primera vez, de forma sistemática y esencial un escritor americano reinserta la voz aborigen en el discurso monológico occidental. En esta especie de contra-conquista -para usar una idea lezamiana- Martí le devuelve el papel protagónico a la naturaleza y al hombre natural. Los adjetivos más hermosos que pude encontrar en su arsenal poético son para la naturaleza americana -que De Pauw y sus acólitos habían degradado- y para el hombre aborigen. Entre Europa y Norteamérica Martí erige, con toda la verticalidad y elocuencia de que era capaz, esta página maravillosa que los colonialismos - en América, en Asia en África-, por soberbia, codicia e ignorancia, habían arrancado del libro de la historia. La noción de progreso surgida durante la Ilustración al amparo del evolucionismo, del positivismo, del pragmatismo y de otras seudo-teorías científicas acunadas en Europa, tiene su origen más remoto en la idea cristiana de la naturaleza corrupta que podía ser manipulada a fin de proporcionarle beneficios al hombre. Esta idea da pie a uno de los relatos más nocivos de la historia que ha pervivido por dos milenios. Como en una 
naturaleza corrupta no debían morar los dioses, el Dios cristiano es separado de la naturaleza y del mundo. Su mensaje a los hombres es: ustedes han sido creados a mi imagen y semejanza y son superiores a los animales y a la naturaleza de la que se pueden servir. Este principio cristiano -que según Joseph Campbell ${ }^{34}$ es una consecuencia de una mala interpretación de las metáforas y los símbolos míticos de la antigüedad- es el principio de la idea de la naturaleza como taller, idea que ha producido catastróficas consecuencias ecológicas para el planeta algo de lo que ya comienza tibiamente a hacerse eco la entidad política.

Pero Martí en el siglo XIX interpreta correctamente las metáforas y los símbolos mitológicos de los antiguos y nos advierte que los dioses y la verdadera justicia están en la naturaleza, templo donde el hombre puede recuperar el equilibrio y la armonía que la sociedad moderna le arrebata. Este es un giro completamente antimoderno de Martí pues reconecta el pasado remoto de las sociedades tradicionales con el presente progresista teleológico, el saber antiguo, con el conocimiento del presente. Así desborda el discurso universalista y monoteísta de la tradición cristiana dominante. Esta concepción fonológica del cristianismo igualmente corrompió el sentido de la eternidad y la trascendencia al otorgarle valores situados más allá de la realidad humana. De forma que Martí disiente de esta teleología historicista porque para él Dios está en la naturaleza, y en ella está la magia y la poesía. El mundo del hombre -para Martí- comienza y termina en la naturaleza. Es el alfa y el omega de la vida. Iris Zavala en "Lyric Poetry and the Constitution of the Self" expresa que "la inserción de la naturaleza que Martí sugiere debe ser soberana y no permitir que el sujeto se subordine (como naturaleza colonizada) a las condiciones del trabajo forzado, sino liberar ambos subjetividad y naturaleza de los 
límites impuestos por la mirada/espacio colonial". ${ }^{35}$ En tal sentido -y esto explica por qué no concibo la idea de una modernidad alternativa para Martí- Zavala deja claro que en lo fundamental y esencial que el poeta cubano establece una ruptura radical con el concepto problemático de civilización occidental, sobre todo con la idea aquí subrayada del hombre como esclavo de nuevo tipo atado a una cadena de producción, en lo fundamental, innecesaria. Al reinsertar la historia de las culturas aborígenes en el discurso euro-céntrico, quiebra la linealidad de éste porque estas culturas no habían roto su nexo con la naturaleza, ni la habían desencantado, ni habían aniquilado a sus dioses ancestrales, ni habían convertido el tiempo en mercancía. Mucho menos habían elaborado una idea de progreso en el futuro como teleología porque esa idea descabellada, desprovista de todo sentido de realidad no entraba en una mentalidad en la cual el thelos estaba en el mito, en la palabra del escriba, en la voz del chamán, interprete a su vez de las voces de las piedras, de los ríos, de las cumbres. De modo que Martí es verdaderamente el primer pensador de la tradición occidental en pensar la modernidad desde la tradición, desde la perspectiva del hombre natural, al punto de incluir en su pensar elementos de la cosmovisión de las culturas aborígenes de América. Eso, desde cualquier punto de vista que se mire es una de las audacias epistémicas más singulares de un pensador americano y un adelanto considerable -otro en este caso- de las más recientes teorías del pensamiento postcolonial.

Martí al reconstituir en su escritura la grandeza y la belleza de la naturaleza americanas, devuelve su espacio descolonizado, libre de la mirada torcida del discurso racional, le devuelve su misterio y su encantamiento. Esta frase debe entenderse en el sentido en que lo analizan Adorno y Horkheimer en Dialéctica de la Ilustración, ese libro 
extraordinario y extraño, según dice Juan José Sánchez en su "Introducción" a la edición española de 1994. Ya en su libro Crítica de la razón instrumental (1967) Horkheimer había planteado que: "La enfermedad de la razón radica en su propio origen, en el afán del hombre de dominar la naturaleza. "Su objetivo fue -continúa el prologuista- 'liberar a los hombres del miedo y constituirlos en señores' [...] y su programa: 'el desencantamiento del mundo' para someterlo bajo su dominio" (12). La Ilustración le entrega a la ciencia el papel de desencantar la naturaleza porque no concibe, ni la diferencia, ni lo desconocido, sino que "opera según el principio de identidad [...] Y ello marca el curso de la desmitologización de la Ilustración, que termina reduciendo todo a la 'pura inmanencia' [...] la 'mimesis' es desplazada por el dominio..." (12). Pero Martí no es signatario de este proyecto racional. Primero porque para él cree que el alma "está por encima de toda la ciencia" y porque cuando ésta termine su ciclo y sepa cuanto hay que saber no sabrá más que "lo que sabe hoy el espíritu".

El escritor cubano crea una doble escritura en su discurso de la autoctonía. Es, yo diría, una página al cuadrado. Por un lado desmiente las falacias del progreso, del universalismo y el euro-centrismo occidentales -con su indigno racismo que él ataca y deshace con justicia-, del historicismo lineal que él rompe para volver a la esfera fraternal de la comunidad, la de los hombres que echan abajo los latines y los libros de la falsa justicia y beben su vino de plátano, los que vencen al criollo exótico. Por otro, entona los cantos sagrados de los Mayas-Quichés, de los Incas, de los aztecas. Desempolva sus mitos poéticos, sus tesoros arquitectónicos, sus libros simbólicos. Se transfunde en su psicología, les devuelve la voz, el gesto, el espacio, el tiempo cosmogónico. La audacia está en que esta alteridad en la que Martí se transustancia es 
una voz sepultada, es decir, voces de una civilización decapitada. De modo que esta heroicidad arqueológica martiana de desenterrar y darle vida nueva a ese mundo autóctono que fue la flor del continente antes de la llegada de los colonizadores es expresión de un alto grado de dignidad y de humanismo ético puesto que lo que restaura, y devuelve con amor a la historia y a la cultura son los sin voz que él trae del silencio, de la oscuridad del colonialismo. Es decir, ese desplazamiento hacia una alteridad inerte, de rostro fijo, de mirada congelada en el filo del acero suicida extranjero, es un gesto de una belleza ética tal, que sólo podría calificarse como una supra-ética. Según Levinas esto es el acto ético supremo pues cuando el hombre sale de sí y se abre a la alteridad en un gesto de absoluta hospitalidad sabiendo que de su gesto humano, fraterno no se puede esperar nada a cambio, sino que es la humanidad del otro lo que impone la ley, ese gesto es la verdadera trascendencia. Sin embargo el heroísmo de Martí está en que, incluso este rostro del otro hacia el que él se desplaza y en quien encarna con su escritura no es ni siquiera ya un ser humano. Es memoria, recuerdo, texto. De modo que él reinserta la fecundidad en la muerte. Este gesto es similar al de otro eticista americano, el poeta peruano César Vallejo quien en su poema "Masa", poema paradigma del humanismo -y que por esas coincidencias del inconsciente de la raza tiene su antecedente en uno de Marti $^{36}$ - recrea de cierta forma esta acción martiana de hacer justicia con los antepasados de Vallejo.
Al fin de la batalla, Y muerto el combatiente, vino hacia él un hombre Y le dijo: "No mueras, te amo tánto!"
Pero el cadáver ¡ay! Siguió muriendo.

Se le acercaron dos y repitiéronle:

"No nos dejes! ¡Valor! ¡Vuelve a la vida!” 
Pero el cadáver ¡ay! Siguió muriendo.

Acudieron a él veinte, cien, mil, quinientos mil,

Clamando: "Tánto amor, y no poder nada contra la muerte!"

Le rodearon millones de individuos,

Con un ruego común: "Quédate, hermano!"

Pero el cadáver ¡ay! Siguió muriendo.

Entonces todos los hombres de la tierra

Le rodearon; les vio el cadáver triste, emocionado;

Incorporóse lentamente,

Abrazó al primer hombre: echóse a andar... ${ }^{37}$

Esta heroicidad ética del combatiente vallejiano y del poeta martiano de restaurar la vida desde la muerte a través del amor, la bondad, la fraternidad humanas alumbra muchas de las ideas sobre la ética que desarrollo en el capítulo V, a propósito del pensamiento de Levinas y Derrida. En este caso la acción poética de Martí y el poema de Vallejo sirven de fundamentación, desde la poética, de los postulados éticos-filosóficos de ambos. Martí. Tanto Vallejo como Martí desarrollan en estos poemas la idea de la trascendencia a través del amor, no del Uno o a través del Uno, sino del todos unánime. Sólo el ruego colectivo, sólo como consecuencia del calor, la ternura y el amor de todos los hombres puede trascenderse la muerte y alcanzarse la verdadera eternidad del instante que es el siempre y el todavía, que es el signo y a la vez la huella. Nada explica mejor toda la filosofía levinasiana y la ética contemporánea en general, que estos poemas. En consecuencia la trascendencia de Martí no responde a ninguna ontología, sino a esta metafísica poética que según Campbell es el origen de las manifestaciones artísticas del espíritu humano. Es decir, la poesía es el lenguaje que intenta atravesar el velo de eso que no se puede expresar, de ese más allá del mundo en el mundo que es el espacio de lo 
inefable, ininteligible, el dominio del Dios humano sin cielo ni infierno y que habita dentro del ser y en la naturaleza.

La cuarta instancia de su escritura ética es el paradigma ético de su ser que trasfigura en el logos. Martí actúa en la ética, desde la ética y para la ética; es su modo de estar en el mundo, fuera del conocimiento, dentro de sufrimiento, del sacrificio y del deber. Si tomamos en cuenta lo que nos dice Wittgenstein de que la ética no es, ni puede ser una ciencia y marca los límites del lenguaje, entonces la ética queda como la verdadera y única experiencia de trascendencia pues en ella se trasciende todo discurso para entrar en la poesía del mundo, del universo, para dar un paso hacia lo extraordinario del asombro. Si para Martí -lo mismo que para Heidegger- la poesía es la fundación de la verdad, esto nos lleva a concluir que para el cubano lo poético es la esencia de lo ético. Si él actúa la ética para fundar la verdad, en esta identificación entre acción y creación el cuerpo y la escritura se hermanan, se hace carne con el signo metafórico y ese signo instaura la polifonía, la heterogeneidad. Ese signo instaurado quiebra la línea y trasciende el orden lógico del discurso para encarnar en el orden simbólico, espacio de absoluta libertad, de anarquía donde la plurivalencia -según Kristeva- "forma una cadena combinatoria que se asemeja a la retórica del sueño",38

\section{Sentido hipertélico del lenguaje en Martí}

La poesía es para Martí su sistema de descubrir e integrar el mundo, de iluminar y ordenar el caos. De ahí que el equilibrio y la síntesis sean dos de los procedimientos dilectos que utiliza para acceder a la verdad desde cualquier fragmento de realidad en que 
opere su visión órfica, están en la base de su hermenéutica. Él entiende-como igualmente su compatriota Lezama Lima- que la metáfora es la negación del tiempo, que en sus ondulaciones se quiebra la línea del sentido historicista. En la distancia, en la lejanía que ya la escritura martiana instaura podemos ver que toda su obra es un magnífico poema sobre el sentido de la existencia humana y que lo que se propuso, como testigo de su tiempo y su palabra fue alumbrar con la irreversibilidad y el sentido de eternidad que palpita en la metáfora los hondos subterráneos del ser con los jeroglíficos de su instrumento lingüístico. No encontró, ni en la filosofía, ni en la historia, ni en la política, ni en la economía, ni en la religión, ni en la ciencia una forma de explicar el mundo y al ser humano con la hondura y belleza que la poesía podía hacerlo. Lo que en este gesto de irregularidad, de corte epistémico se verifica, es la certeza de la reconexión que el espíritu de Martí hace con un pasado remoto, un pasado que se pierde en la sombra de su lejanía, en ese tiempo y ese mundo anterior al imperio de la razón que él redescubre cuando penetra en el texto de la América del "hombre natural" que en él reencarna.

Entonces se da cuenta, "mirando" los libros sagrados de América, de que esa forma que tienen los aborígenes de llamar a la Vía Láctea "el camino de las almas", es similar a lo que cuenta Lezama, sobre la muerte de los reyes egipcios. Los cortesanos cuenta Lezama- no atendían "a los gestos evidentes, la descomposición de la carne [...] Decían, para explicar su partida: El faraón se ha hundido en la línea del horizonte (38). ${ }^{39}$ Se percata de que éstos son pueblos que viven en la metáfora, que viven en la. De modo que aquí Martí ve una conexión supra-temporal. En otras palabras, ve, a través de su arqueología y su intuición, que ese lenguaje no causal, que no registra la finitud del tiempo, saturado de esencias míticas, es el verdadero lenguaje del hombre que fatalmente 
ha sido colonizado y que él descolonizará en la medida de lo posible. Sólo esto bastaría para definirlo como un pensador original y a contracorriente de las metanarrativas de su época porque sólo aquí hay dos negaciones martianas, muy caras al pensar moderno: el tiempo y la historia. Y cuando digo dos negaciones éstas deben ser entendidas, no en el sentido de descartarlas por completo en su cosmovisión, sino en el sentido de oposición al concepto raquítico que la racionalidad occidental vierte en ellos, especialmente a partir de la Ilustración. En otras palabras, lo digo en el sentido de que su pensar desborda estas categorías gnoseológicas estratificadas y despojadas del thelos de lo arcano, de lo místico o para usar un término de Levinas, el "sentido del encantamiento del mundo" que en él sigue vivo por la índole de su visión órfica y su ente mítico. Para Lezama-que lo estudia con el espejo de paciencia de su corazón de lámpara- hay en la escritura de Martí una calidad y un ethos de una sustantividad misteriosa y fecundante.

El autor de Paradiso define la hipertelia como el acto de engendrar en la palabra lo que va más allá de la finalidad, es decir, ese límite en que se rompe cualquier causalidad y la imagen puede engendrar el sucedido. Para él la palabra de Martí tiene esa cualidad en grado sumo. Culmina este pensamiento aludiendo a ciertas antiguas teogonías en las que "cuando un dios copula, no con una diosa, sino con su representación humana, con su hieródula, comienza a llover. Detrás del simbolismo de esta unión "entre un dios y una semilla humana, para nosotros permanece indescifrable, pero esa lenta caída de la lluvia, simbólica de la cascadura de la semilla por el humus, quiere penetrar en la situación simbólica"40 y adivinar lo que se esconde detrás del velo. Pero se sugiere que el símbolo es un acto de bondad. La unión del hombre y la divinidad abre un horizonte de posibilidades, de semillas y de frutos, engendra una vivencia oblicua en que la figura del 
hombre se desdibuja como una metáfora. En el espacio de lo indiferenciado que es a la vez polifónico, en que convergen lo uno y lo diverso se instaura la voz poética de Martí que viene a prefigurar una conducta que se engendra siempre en un horizonte de lluvias, de posibilidades, en un sentido hipertélico que recuerda -de acuerdo a Lezama- las palabras de San Mateo cuando dice: "Siego donde no sembré y recojo donde no esparci"41 donde se rompe toda posible causalidad. Por eso dice que Martí es un hombre "traído para agrandar, para vivir la hipérbole de la extensión de un dominio, sabe que lo que él logre dilatar será ya sustancia que habrá que llevar hasta allí, hasta el ondulante límite de su imaginación". ${ }^{42}$

La elección de su sistema poético como hermenéutica predilecta en medio de la apoteosis racional que le tocó vivir, cuando la ciencia ha sido investida con el aura de la infalibilidad como discurso privilegiado de la modernidad y la poesía ha perdido el prestigio de que ha gozado como instrumento de la verdad, es uno de los actos más revolucionarios y audaces de su palabra. La ciencia -como se sabe- está volviendo de su embriaguez infalible a juntarse de nuevo con las expresiones del espíritu y dentro de la física cuántica ha surgido un nuevo paradigma que clama por la reunificación entre materia y espíritu que se rompe con Newton en el siglo XVII. De todas sus audacias epistémicas -que no son pocas- ésta de elegir la poesía como método del saber, de búsqueda de las verdades últimas que desvelan al hombre es quizás la mayor de todas. Porque a fin de cuentas el lenguaje de la ética es la poesía. No hay en el pensamiento del hombre y en la realidad del mundo ningún lenguaje que exprese la pluralidad, la heterogeneidad y la diversidad de todo lo que existe y nos es dado penetrar que la metáfora -altérica por naturaleza- y ésta es el corazón de la poesía. 
' Pedro Henríquez Ureña: Las corrientes literarias en América Latina. (México: Fondo de Cultura Económica, 3ra. Reimpresión, 1969), 167.

${ }^{2}$ Ensayo presentado por Ángel Rama como ponencia en el Seminario Martí celebrado en la Universidad de Puerto Rico (Recinto de Río Piedras) en Febrero de 1971.

3 Para un análisis más detallado de estas ideas ver acápite "Interrogación de la modernidad" en $L a$ dialéctica de la modernidad en José Martí y además en José Martí en el eje de la modernización poética: Whitman, Lautréamont, Rimbaud.

${ }^{4}$ En Temas martianos, 248.

5 Para una más extensa valoración de este aspecto véase el ensayo citado "Los versos de Martí" en Temas martianos, 248-252.

${ }^{6}$ Iván A. Schulman. Las entrañas del vacio. En "El escritor y las disyunciones de la modernidad", Schulman analiza el aspecto concerniente a la marginación del escritor en el mercado capitalista moderno y como Martí, a partir de su visión peculiar de la literatura, y su sentido crítico del arte somete al contexto económico social en que vive a una severa crítica de la que no se excluye él mismo como en su poema "Musa traviesa", 93.

${ }^{7}$ Es curioso que en el prólogo señalado Cintio Vitier, además de exponer los paralelos entre la poesía de Vallejo y Martí, sobre todo un poema inconcluso de Martí en uno de sus cuadernos de apuntes y el célebre "Masa" de Vallejo.

${ }^{8}$ Para un examen más extenso de esta tesis de la "modernidad alternativa", véase el apartado 6 "José Martí y las estrategias del discurso (contra) moderno" en El proyecto inconcluso: La vigencia del modernismo, 109-123.

9 Este libro es fundamental en la exégesis martiana. Viene a constituir un magnífico estudio del modernismo y de la obra de Martí hasta considerar que el poeta cubano no tuvo nada significativo que ver con el modernismo, es decir habla ya de su anti-modernismo.

${ }^{10}$ Cintio Vitier ha recogido en su libro Marti en Lezama, todas las revelaciones que el autor de Paradiso va haciendo sobre el héroe cubano a lo largo de tres décadas, comenzando en 1948 con su ensayo "Las imágenes posibles" en el cual comienza a prefigurar su gnoseología poética.

${ }^{11}$ Vitier, 22.

${ }^{12}$ Manuel Pedro González. "Evolución de la estimativa martiana" en Martí, Dario y el modernismo en colaboración con lvan A. Schulman y prólogo de Cintio Vitier.

${ }^{13}$ Del artículo "Forma y pensamiento en José Martí" de Roberto Fernández Retamar, incluido en las actas del coloquio internacional celebrado en Alicante en marzo de 1995 José Martí: Historia y literatura ante el fin del siglo XLX: Pág. 34. Publicado por la Universidad de Alicante en su colección América Latina, 33134.1 .

${ }^{14}$ José Martí. Correspondencia a Manuel Mercado. (La Habana: Centro de Estudios Martianos, 2001), 32

${ }^{15}$ Diana Paris. Julia Kristeva y la gramática de la subjetividad. (Madrid: Campo de ideas, 2003), 27 
${ }^{16}$ Utilizaremos a lo largo de toda la disertación, excepto para la poesía la edición de las Obras Completas de Martí publicadas en 28 tomos por la Editorial de Ciencias Sociales, La Habana, 1975 en su versión digital. Señalaremos en el texto solamente el número del tomo y la página del texto.

${ }^{17}$ Michel Foucault. Nietzsche, Freud, Marx. (Barcelona: Editorial Anagrama, 1965), 9

${ }^{18}$ Carlos J. Rojas Osorio. Foucault y el pensamiento contemporáneo.( San Juan: Editorial de la Universidad de Puerto Rico, 1995), 94.

${ }^{19}$ Michel Foucault, 30.

${ }^{20}$ Foucault, 16.

${ }^{21}$ Cintio Vitier y Fina García Marruz. Temas martianos.( La Habana: Instituto Cubano del Libro, 1969).

${ }^{22}$ Roland Barthes. El grado cero de la escritura: seguido de Nuevos ensayos críticos. (Buenos Aires: Siglo XXI Editores, 2003).

${ }^{23}$ José Martí. Poesía completa. Edición crítica, 2a ed. (La Habana: Editorial Letras Cubanas, 1993), 57.

${ }^{24}$ Cintio Vitier. "Los Versos sencillos" en Temas martianos, 170.

${ }^{25}$ José Martí, 238.

${ }^{26}$ Ezequiel Martínez Estrada. Martí revolucionario. (La Habana: Casa de Las Américas, 1973).

${ }^{27}$ Walter D. Mignolo. "Colonialidad global, capitalismo y hegemonía epistémica" en Culturas imperiales. (Buenos aires: Beatiz Vitrebo Editora, 2005), 57-87.

${ }^{28}$ Iván A. Schulman. El proyecto inconcluso: la vigencia del modernismo.(México: Siglo XXI Editores), 112.

${ }^{29}$ Fina García Marruz: “El escritor” en Temas martianos, 209.

${ }^{30}$ Piazze, Juan. "Foucault: poderes-saberes, disciplinamientos y sexualidades. Algunas reflexiones sobre la muerte suscitadas por la ética del cuidado de sí" Revista Observaciones Filosóficas no. 2 (2006): 2-7. http//observacionesfilosoficas/net

31 José Marti. Correspondencia a Manuel Mercado. (La Habana: Centro de Estudios Martianos, 2001), 273.

32 José Martí, 28.

${ }^{33}$ Juan Piazze, 5.

${ }^{34}$ Uno de los más renombrados especialistas de la mitología del siglo $\mathrm{XX}$, autor de más de veinte libros entre los cuales se destacan: El viaje del héroe, El héroe de mil caras, Las máscaras de Dios, entre otros.

${ }^{35}$ Iris Zavala. Coloniamism and Culture. (Bloomington and Indianápolis: Indiana University Press, 1992), 53-54.

${ }^{36}$ En el prólogo al libreo de Ivan A. Schulman y Manuel Pedro Gonzáles Martí, Darío y el modernismo Cintio Vitier se refiere a este borrador para un posible poema de Martí que nunca llegó a terminar y que aparece en uno de sus cuadernos de apuntes. 
"¡Después de esto - volver a la vida diaria!"

y se saltó de un balazo el cráneo.

Comenzaron entonces a clamar todos los que necesitan del hombre.

Pasó la humanidad, y lo maldijo.

¡Oh poeta! ¡Ahora, quién echará aceite en la lámpara!

¡Oh sufridor! ¡quién abonará por el olvido de los torpes

$\mathrm{y}$ de los indiferentes!

En la vida, es necesario que unos se consuman en beneficio de los otros.

¡Oyó; se levantó dolorosamente: compuso los huesos rotos

de su cráneo, y siguió andando!

${ }^{37}$ César Vallejo. Poesía completa. Poesía completa. Ed. Crítica y studio Raúl Hernández Novás. (La Habana: Arte y Literatura, 1988), 378.

${ }^{38}$ Diana Paris, 38.

${ }^{39}$ Centro de Investigaciones Literarias de la Casa de las Américas. Interrogando a Lezama. Barcelona: Editorial anagrama, 1971.

${ }^{40}$ José Lezama Lima. Confluencias: selección de ensayos. (La Habana: Letras Cubanas, 1988), 350.

${ }^{41}$ Lezama, 51.

${ }^{42}$ Lezama, 208 


\section{Capítulo II}

\section{Contra-discurso de la modernidad estética.}

"¿Quién es el ignorante que mantiene que la poesía no es indispensable a los pueblos? Hay gentes de tan corta vista mental, que creen que toda la fruta se acaba en la cáscara. La poesía [...] es más necesaria a los pueblos que la industria misma, pues ésta les proporciona el modo de subsistir, mientras que aquélla les da el deseo y la fuerza de la vida"

José Martí "El poeta Walt Whitman"

\section{La escritura martiana y la modernidad estética.}

Los conceptos de moderno y modernidad hunden sus raíces hasta la temprana Edad Media. En Modernidad inconclusa Habermas plantea que la palabra "moderno empezó a usarse a fines del siglo $\mathrm{V}$ para deslindar el presente que se había convertido oficialmente en cristiano, del pasado romano-pagano" (1). El cambio que constituye la institucionalización de nuevas creencias y actitudes y la imposición de una dirección unidimensional en el horizonte espiritual humano, opuesto a la diversidad del mundo pagano, introduce una visión antagónica de la vida que desde ese momento mirará al pasado con cierto recelo y cierta distancia que se irá incrementando en la medida en que la nueva tradición cristiana se afianza. Ya hacia el siglo XII los términos modernitas y moderni eran -según Calinescul- frecuentemente usados y había surgido un grupo de poetas con una visión estética conflictiva; por un lado los que defendían la poesía de la antigüedad y por otro los que ya se denominaban moderni. Este enfrentamiento -que en 
opinión de Habermas ocurre en Europa cada vez que surge la conciencia de una nueva época, opuesta a los modelos antiguos- se agudiza hacia el Renacimiento, etapa que crea sus propios conceptos críticos destinados a desautorizar a los maestros de la antigüedad. Este proceso se consolida definitivamente con las ideas de la Ilustración francesa. "Los Ensayos de Montaigne (1580), los Avances del aprendizaje y Órgano Nuevo (1605) de Francis Bacon y el Discurso del método (1634) de Descartes son algunos de los más importantes hitos en la historia de la consagración de la modernidad",2, son algunos de los más importantes hitos en la consagración de la modernidad. Estos autores dan un tiro de gracia a la que hasta entonces había sido la fuente de los modelos: la antigüedad clásica.

Con la entronización de la razón, del discurso científico y de la doctrina del progreso se crean las bases filosóficas para la solidificación del rumbo hacia el futuro que tomará a la sociedad moderna. De tal modo, liberada de toda jerarquía, puede perfilar su propio destino sin tener que venerar ningún modelo. Comienza entonces el proceso de entronización de la individualidad y la novedad como marcas operativas del nuevo orden social. Se abran las puertas a la crítica del pasado con la manifiesta intención de desacreditar la maestría de los clásicos. El artista moderno -comenta Calinescu- está mejor dotado que el clásico pues posee instrumentos más precisos e infalibles para alcanzar la "perfección artística". Así Charles Perrault poder escribir una Eneida mejor que la de Virgilio y Homero, el más antiguo de los poetas griegos "es el más frecuentemente atacado por sus errores e inexactitudes científicas". Cómo puede Homero decir que Ulises "es reconocido por su perro al que no ha visto por veinte años, cuando Plinio ha dicho claramente que un perro no pude vivir por más de quince". ${ }^{3}$ Tales discusiones, -que no han de ser tomadas a la ligera en el contexto del siglo XVII francés- 
muestran cómo la ciencia y la razón comenzaban a penetrar los ámbitos de la creación artística y cómo la autoridad de la tradición había sufrido una considerable erosión en lo que al saber y al gusto se refiere.

El terreno está preparado para que se produzcan los cambios conceptuales que indican el paso del plano de la trascendencia al plano de la inmanencia. Ya desde los románticos se viene desechando la idea de belleza como un concepto eterno, y comienza a adoptarse una basada en la experiencia histórica. Es la primera manifestación de rebelión del artista moderno contra la normatividad. En su Modernidad inconclusa Habermas cita a Adorno cuando afirma que "los signos de la destrucción son el sello de autenticidad de la modernidad; aquello mediante lo cual se niega desesperadamente la armonía de lo permanentemente igual; la explosión es una de sus constantes" (4). El otro cambio sustancial ocurre con el concepto del tiempo al que se le introduce poco a poco un valor mercantil hasta convertirlo en uno de los valores de cambio esenciales de la modernidad: es un tiempo controlado y medido cada vez con más precisión. Adquiere un valor utilitario y, en consecuencia, va penetrando silenciosamente las reposadas parcelas de la creación artística -las que menciona Martí en El poema del Niágara- donde establece dominio comercial. Esta circunstancia es el resultado de la interacción que se produce en el marco de dos concepciones de modernidad en oposición. Por un lado cobra fuerza una modernidad determinada por la eficiencia científica a la que se le añade una doctrina de progreso material, un sentido pragmático y utilitario del tiempo, una relatividad y un causalismo históricos. Por otro, se desarrolla una modernidad opuesta al materialismo y al racionalismo burgués, a la banalidad de la vida que esta clase porta con ella, a la vulgaridad y el deterioro del gusto y -más severo aún- a la marginalización del 
artista. Desde principios del XIX este antagonismo se ha mantenido como una batalla de irreconciliables contrarios.

De manera que la cultura moderna sacraliza la individualidad, relativiza el concepto de belleza, apuesta al gesto iconoclasta, al experimento formal, al exotismo, a la apoteosis de la novedad, a lo inverosímil. Al adoptar estas premisas la modernidad estética sienta las bases para el surgimiento de un concepto de arte sin propósito que desemboca en el precepto de 'el arte por el arte'. "El concepto central de Gautier en su prefacio a Mademoiselle de Maupin (1835) es típicamente negativo, una definición de belleza en términos de total inutilidad". Es la primera vez que los nexos con la tradición del pasado se rompen completamente y el artista, dueño absoluto de su ideal de novedad, sin modelos a imitar, elabora su propia estética. Esta libertad que se expresa en la capacidad de innovación constante, conduce al artista a desarrollar una individualidad portadora de un sentido de superioridad, de infalibilidad, de genialidad que lo aparta de la realidad. Su acto creativo se convierte en una aventura perpetua en la que sólo lo acompaña su imaginación. Sin embargo, esa postura extraña tiene sus riesgos puesto que la imaginación es un producto de la psiquis humana, un universo complejo, lleno de contradicciones y, además, en su mayor parte desconocido para el hombre. De modo que en esta carrera de larga distancia que el artista emprende a solas con los fantasmas de su inflamada conciencia se expresa cierta tragicidad. Este arte convertido en culto, que más de las veces se encierra en su torre de marfil necesita de un contexto que retroalimente esa imaginación. En otras palabras, el artista no pude disociarse de la realidad sin correr el peligro de aniquilarse a sí mismo. Esta negatividad, expresada en el aislamiento, ya sea en el sentido del elitismo o en el de la soledad y la necesidad de aprehender una realidad 
contradictoria conduce inexorablemente al callejón sin salida del nihilismo de las vanguardias.

La conciencia crítica que Martí despliega frente a los fundamentales presupuestos de la estética moderna produce una escritura que, al desplegar su tejido en el ámbito de la ética, desborda los conceptos epistémicos que dan fundamento a este período histórico. Ni siquiera al inicio de su carrera se deja seducir por estos nuevos cambios de la modernidad estética europea que auguran una absoluta libertad para el creador. En principio su sentido de la originalidad artística no está en la ruptura o la negación del pasado. Esta idea le es extraña porque va contra su criterio del equilibrio y la armonía de todos los elementos que componen la realidad. El sabe que el conocimiento del mundo que el hombre posee no es algo nuevo, no es producto de la Ilustración, sino que se hunde en un pasado muy lejano. De manera que la constante ruptura que inaugura la modernidad, no entra en la concepción estética martiana. De igual forma disiente del relativismo histórico que inaugura este período y que constituye a todas luces una crítica de la tradición, lo mismo que de su ideal de belleza pues para él la belleza es una experiencia humana situada más allá del capricho individual de cada artista o de los preceptos estéticos de una escuela o una época. El concepto de belleza en Martí está indisolublemente vinculado a la naturaleza del mundo y del ser y en él entran expresiones como la bondad, la justicia, el amor, la armonía y el equilibrio. D esta manera es una experiencia para compartir con el otro, de abrirse a la experiencia radiante de la alteridad. En tal sentido tiene un carácter trascendente. La belleza no puede ser para él una parcela de la realidad desconectada de la energía que atraviesa la materia y el espíritu, sino que se da en la fusión de ambas realidades. Al disentir de estos nuevos preceptos artísticos se 
convertirse en el primer escritor de habla hispana en hacer una crítica radical de la estética modernista.

Martí es, en esencia, un pensador asistemático que opera en la interpretación de la realidad, con los procedimientos, la experiencia y la sabiduría de civilizaciones de distintas épocas históricas -incluidas las civilizaciones precolombinas- pero sobre todo con el instrumental de su hermenéutica poética. De las diversas tradiciones hace una síntesis y lo refunde todo en su fragua criolla. Lo que resulta es un eclecticismo portador, más que de un sistema de conocimientos, de un tratado de sabiduría. La multiplicidad de discursos que conforman su escritura, tocan casi todos los aspectos de la realidad de forma original y le otorgan, a la vez, una energía revolucionaria que nace del paradigma de su escritura ética, que es a un tiempo acto y palabra. Esta particularidad hace posible la poeticidad de su discurso pues "su mirada no es analítica, sino vidente, sintetizadora; su inteligencia no es causalista, sino poética". ${ }^{5}$ En su escritura poética se nota la presencia actuante del ritmo, de la música y de la metáfora en su aprehensión de la realidad. Este actuar de la ética en el horizonte de la poesía hace que estos universos se fundan: ética y estética, belleza y bondad, acción y contemplación, ser y realidad. A estas dimensiones añade el amor como forma de conocimiento -como veremos más adelante- pues niega la idea moderna de que el conocimiento sea sólo accesible por la vía unilateral del pensamiento racional. Para Martí el amor es quien ve y lo bello es una forma de la verdad. Así supera la falsa antítesis del arte y la vida, -común a casi todos los modernistas-, como igualmente supera la del espiritu y la ciencia. De la síntesis que hace resulta una estética de la existencia, sorprendentemente muy similar a la que elabora Foucault quien cree que el individuo debe desarrollar una vida para la ética, como 
plenitud de lo posible. El filósofo francés "ve con entusiasmo que los estoicos hayan desarrollado una ética independiente de lo religioso y lo jurídico, basada más bien en una opción personal. Esta hermenéutica del ser (que no es más que una liberación del gobierno de las estructuras del poder/saber del estado moderno), estaba ya en el Prólogo poema del Niágara de 1882 y es uno de los adelantos más asombrosos de Martí a la teoría contemporánea.

\section{Desbordes modernistas de su escritura}

Contrario a los modernistas y a contracorriente de la modernidad, Martí abre el pasado y se sumerge en él como arqueólogo y como etnógrafo a desenterrar, no las ciudades sumergidas por el tiempo, sino las culturas decapitadas por el colonialismo europeo, los signos rotos y calcinados de las civilizaciones de su América mestiza, para insertarlos en el discurso euro-céntrico racional y universalista de Occidente. El pasado no es para él sólo la antigüedad clásica (que tan bien conoce y admira), o la historia de las civilizaciones, siguiendo el logo-centrismo occidental. Para él el pasado también lo constituyen las civilizaciones silenciadas, condenadas al olvido, pero que fueron en su momento florecientes y prósperas sociedades. Martí les devuelve su tiempo y su espacio para que vuelvan a hablar sus lenguas antiguas, entonen sus cantos sagrados a las piedras y los bosques, reabran sus calendarios y sus libros mágicos abiertos a la poesía del universo. Porque no se puede autodenominar civilizada ninguna sociedad que deje en el olvido o silencie una parte de ella. Para Martí ninguna civilización es exclusiva o superior a las demás y con este pensar suyo está rectificando conceptos cardinales que el 
historicismo teleológico occidental había distorsionado en sus afanes coloniales. En su cosmovisión del mundo -formada ya cuando comienza su exploración logo-arqueológica del pasado- el concepto de lo diverso, de lo múltiple, de lo heterogéneo es un principio esencial. Por eso se opone al individualismo que despliega el artista en la modernidad. Para él el -como más tarde demostrará Jung- el ser humano lleva grabado en los arquetipos del inconsciente los sentimientos de solidaridad, hermandad, colectividad. De modo que la exacerbación del individualismo que la modernidad preconiza y estatuye es en su óptica una desviación de las experiencias naturales del hombre, es una disminución de su humanidad. Esa apreciación aparece analizada con una hondura y una belleza poética admirables en El poema del Niágara donde el hace su diagnóstico de la crisis de la modernidad. Martí explica en este documento hipertélico que lo necesario para el hombre es desarrollar en un proceso de individuación, que es emprender el viaje interior hacia la conquista de su propia humanidad, y no el desarrollo del individualismo que es el viaje hacia el exterior en que la humanidad del hombre se entrega al gobierno de la razón que lo convierte en víctima de ideologías ajenas a su esencia humana.

El subjetivismo que despliega el Renacimiento y que alcanza su apoteosis con la Ilustración instaura en el pensamiento occidental una tensión entre antigüedad y modernidad de la que emerge una visión homocéntrica de la vida. Su reflejo más visible es la actividad secular cada vez más acentuada en el individuo dentro de la sociedad. No es la primera vez que se da en la historia -como tendremos tiempo de analizar-pues está asociada a una tradición que se remonta a los primeros siglos de la era cristiana, pero a partir del desmoronamiento de la Edad Media, cobra caracteres singulares. La jerarquía de valores y el principio de autoridad cede al impulso arrollador del individualismo que 
había sido contenido por varios siglos dentro de cauces espirituales rígidos, dogmáticos, que al cabo resultan asfixiantes para las expresiones del libre albedrío. En esta etapa la estructura político-social dominante se agrieta y los hombres empiezan a rivalizar con la divinidad en el control de su destino y a situarse en el centro del universo. Es decir, el trono de Dios es desplazado por el trono del hombre que desde entonces será la medida de todas las cosas. Asistimos así al nacimiento de la episteme antropocéntrica que con la Ilustración alcanza el dominio del pensamiento moderno. Pero este centro, hacia principios del siglo XIX, comienza a manifestar su desequilibrio, en la medida en que se destapan y afloran los abismos existenciales, que al comienzo de la liberación de las cadenas teológicas, no eran visibles. En este nuevo renacer, confiado en el poder de la razón y la ciencia, el hombre otorga poderes ilimitados a su propio desenvolvimiento como especie, rivalizando, no sólo con la divinidad ancestral, con la tradición -que considera ahora obsoleta-, sino además y lo más peligroso, con el propio mundo que lo acuna y sustenta. De ahí que su aventura de expansión, conquista y colonización no encuentre límites en el espacio que se despliega ante su visión. Este giro del pensamiento, esta nueva herida racional, viene como una imposición y no como resultado de un proceso evolutivo natural. Nietzsche nos confirma -según Calinescu- que las palabras fueron siempre inventadas por las clases superiores y no indican un significado, sino que más bien imponen una interpretación.

Durante los últimos ciento cincuenta años aproximadamente, los términos "moderno", "modernidad", y más recientemente "modernismo"... han sido usados en contextos artísticos y culturales para trasmitir un sentido agudo de relativismo histórico. Este relativismo es, en sí mismo, una forma de crítica de la tradición. Desde el punto de vista de la modernidad, el artista, gústele o no, es separado de las normativas del pasado con sus criterios fijos, y la tradición ya no tiene ninguna legítima autoridad para 
ofrecerle modelos a imitar o direcciones a seguir. Con lo que tenemos que lidiar aquí es con un profundo cambio cultural que va de una estética de la permanencia que privilegiaba el tiempo, basada en la creencia de un trascendental y permanente ideal de belleza, a una estética de la transitoriedad e inmanencia, cuyos valores centrales son el cambio y la novedad. ${ }^{6}$

Es Baudelaire el primero en oponer la visión estética de la tradición y la modernidad. Para él ésta "es lo transitorio, lo fugitivo, lo contingente, la mitad del arte, en el que la otra mitad es lo eterno, lo inmutable..." (4-5). Con el paso del tiempo la autocomplacencia de la estética de la transitoriedad, de la impermanencia, de lo fugitivo como algo novedoso, termina imponiendo su violencia sobre lo tradicional que se presenta al artista como un modelo superado. Esta explosión de la subjetividad estableciendo su nueva jerarquía será el caldo de cultivo para la posterior rebeldía de las vanguardias. En lo adelante no hay Dios que reverenciar, ni padre que obedecer. Lo eterno se disuelve en lo cotidiano que es lo que dicta la ley y el destino. El tiempo comienza a cobrar valor bajo la batuta del utilitarismo burgués. A éste se opone un tiempo identificado con el ser, creado por el artista para su disfrute. Es un tiempo individualizado que rivaliza con el del mercado. Su rebeldía e inconformidad arrancan de esta usurpación de su tiempo y de su espacio, de la disolución de su antiguo prestigio, como veedor y guía espiritual de la sociedad. El nuevo estado no está interesado en prestigiar el trabajo de un individuo cuyo pensar es portador de una autoridad y un valor que vienen desde la antigüedad y que por tanto rivaliza con los intereses de la nueva clase en el poder. "La sociedad moderna no puede perdonar a la poesía su naturaleza: le parece sacrílega...El poeta tiende a participar en lo absoluto, como el místico; y tiende a expresarlo, como la liturgia y la fiesta religiosa". ${ }^{7}$ Octavio Paz se hace eco del tema de la 
voz poética como ente liberado de las estructuras del poder pues su comunicación es el resultado de una comunión con las esencias del ser y del mundo y por tanto no requiere la aprobación de autoridad alguna. El poeta mexicano afirma que esta pretensión mística:

...lo convierte en un ser peligroso, pues su actividad no beneficia a la sociedad; verdadero parásito, en lugar de atraer para ella las fuerzas desconocidas que la religión organiza y reparte, las dispersa en una empresa estéril y antisocial. En la comunión, el poeta descubre la fuerza secreta del mundo, esa fuerza que la religión intenta canalizar y utilizar, a través de la burocracia eclesiástica. Y el poeta no sólo la descubre y se hunde en ella: la muestra en toda su aterradora y violenta desnudez al resto de los hombres...

Para él la poesía es un testimonio del éxtasis, del amor dichoso, y por esa vía establece igualmente contacto con el estado nirvana de los orientales. No es casual que Martí afirme ser unas veces místico y otras estoico, describiendo una parte de su ser en lo general no conciliables o comunes en un mismo hombre. Desde la más remota antigüedad la palabra poética ha sido la voz del iniciado, el que junta el acá y el allá, o el que, como Martí, es capaz de penetrar las junturas del universo y por tanto pronunciar una inmortal poesía. Un pensamiento de Novalis citado por Fina García Marruz en su ensayo "Martí escritor" ilustra la idea anterior: "un poeta que fuera a la vez un héroe... sería un enviado de Dios". ${ }^{9}$ En Martí se dan esas dos dimensiones, él es un ejemplar del poeta-héroe de que habla Novalis. Octavio Paz completa la idea de la siguiente manera: "El poeta era mago y sacerdote y su palabra era divina. Esa unidad se rompió [...] en el momento en que la división del trabajo creó una clerecía y nacieron las primeras teocracias"10, aunque esa escisión entre la poesía y la sociedad nunca fue total. Pero dice Paz -muy a tono con lo que explica también Calinescu- que el "gran divorcio comienza en el siglo XVIII y 
coincide con el derrumbe de las creencias que fueron el sustento de nuestra civilización. Nada ha sustituido al cristianismo y desde hace dos siglos vivimos en una especie de interregno espiritual". " Veamos que dice Martí en El poema del Niágara:

Nadie tiene hoy la fe segura. Los mismos que lo creen, se engañan. Los mismos que escriben fe se muerden, acosados de hermosas fieras interiores, los puños con que escriben... Todos son soldados del ejército en marcha...En todos está hirviendo la sangre nueva. Aunque se despedacen las entrañas, en su rincón más callado están, airadas y hambrientas, la Intranquilidad, la Inseguridad, la Vaga Esperanza, la Visión Secreta. (VII, 225)

La batalla mantenida por estas dos irreconciliables modernidades ha conducido a la cultura anti-burguesa a un punto de agotamiento de sus posibilidades expresivas. Hacia 1950 un filósofo de la historia como Arnold Toynbee acuña el concepto de postmodernismo para referirse al arte que sigue a las vanguardias A partir de ellas el nihilismo propio de los modernistas y vanguardistas se tornará en la ironía, el sarcasmo y el coqueteo del gesto intrascendente que desemboca en el Kitsch. En criterio de Bell este agotamiento de la cultura postmoderna es el resultado directo de la banalización generada por una estética autocomplaciente que esquiva el compromiso social, escudada en la experimentación y la máscara. En su libro Las contradicciones culturales del capitalismo, plantea que se ha producido "una separación radical de la cultura y la estructura social, y es tal separación lo que históricamente prepara el camino para revoluciones sociales más directas". Luego concluye que la nueva revolución va por dos caminos. "Primero, la autonomía de la cultura, conquistada en el arte, comienza ahora a trasmitirse al escenario de la vida... Segundo, el estilo de vida practicado por un pequeño cenáculo... es ahora copiado por la mayoría". ${ }^{12}$ No obstante, de acuerdo a Calinescu, si 
miramos el plano social más en profundidad, veremos que las manifestaciones culturales de hoy tales como el "hedonismo pop, el culto a la gratificación instantánea, la moral del entretenimiento y la confusión general entre la realización personal y la simple autogratificación" tienen su origen en el capitalismo como sistema, cuyas contradicciones no se originan en el plano de la cultura o el arte, sino en su propia filosofía y arquitectura. Más adelante añade que "nacido de la ética laboral protestante, solamente se pudo desarrollar estimulando el consumo, la movilidad social, y la búsqueda de un estatus, es decir, negando su propia trascendencia moral". ${ }^{13}$ La escritura martiana hunde sus raíces en una profundidad que desborda esa actitud aciaga de la vida porque el destino humano para Martí estaba por encima de las construcciones discursivas de una tradición signada por relatos apocalípticos. Al romper con su herencia cultural -como lo hace en tantas diferentes instancias- tiene la posibilidad de recopilar en otras un saber más vinculado a las esencias del ser y menos vulnerable al drama existencial en que el universalismo occidental sumió al hombre de esta civilización. En contraste con esta intención de universalidad y permanencia del poeta revolucionario está:

la negación modernista de la estética de la trascendencia, del ideal de la permanencia -negación que inspira ciertas tendencias vanguardistas extremas, tales como las representadas por las "esculturas" mecánicas autodestructivas de Tinguely- tiene su verdadero paralelo grotesco en la inherente obsolescencia de tantos objetos kitsch y en la noción general de "arte de deshecho" propuesto por ciertos teóricos del movimiento pop. ${ }^{14}$

Las constantes rupturas con los nexos de origen, así como los malabarismos epistemológicos con que juega, produce la crisis que experimenta el arte moderno, con la consecuente fragmentación del individuo quien estará, desde entonces, en la búsqueda 
constante de un centro o de un horizonte de posibilidades donde reinsertar su existencia. No en vano el poeta de mirada órfica entiende que las corrientes subterráneas del ser donde yace la verdadera sabiduría, -representadas a lo largo de la historia en las ideas paganas, eraclíteas, esotéricas, budistas, místicas o alquímicas- hay que mantenerlas vivas porque constituyen el nexo indestructible con la raíz y porque si se apagan esas luces, corre peligro de apagarse la vida. Toda luz que haya brillado en el pasado alumbrando la libertad, la dignidad, la bondad, la diversidad y el amor de y entre los seres humanos hay que mantenerlas encendidas. No se puede fundar un arte perdurable sobre una constante negación. El telos de la poesía no pude ser ni pragmático, ni utilitario, ni progresista, sino metafórico, simbólico y mitológico.

Si el presente se vacía del pasado, igualmente se vacía de sí mismo. Si la belleza se divorcia de la naturaleza, se divorcia del hombre y en consecuencia se vuelve mecánica, como esas esculturas de desechos que proliferan en los espacios urbanos, como testimonio de las ruinas del progreso. La cultura de la transitoriedad, del disfrute instantáneo libera al hombre temporalmente -como las drogas y los sucedáneos- de las miserias cotidianas, pero una vez deshecho el objeto/hechizo, deja de nuevo vacío y huérfano al sujeto. En este cuadro de angustia existencial, de desequilibrio e inarmonía, resultado de una anarquía subjetiva sin horizonte visible, está el origen de las patologías que padece el ser moderno y que se expresan en la esquizofrenia, la psicosis, el individualismo corrosivo, la evasión y el consumismo galopante que sufre el individuo de la sociedad industrializada. El paisaje psicológico del hombre moderno muestra una angustia, una depresión y una psicosis no igualada en ninguna otra etapa anterior de la humanidad. Despojado de su tiempo esencial, de su divinidad interior, de su patria 
natural, de su sentido de fraternidad y hermandad, en fin, de su humanidad, queda el ser degradado, mecánico, automático.

\section{Belleza y bondad como esencias del arte.}

Martí difiere del concepto de belleza que inaugura la modernidad. A partir del siglo XVIII -como vimos- el concepto clásico de belleza comienza a perder poco a poco su sentido de impermanencia. "Es durante el siglo XVIII que la idea de belleza comienza a perder su aspecto trascendente hasta convertirse en una pura categoría histórica". ${ }^{15} \mathrm{Ya}$ los románticos habían desechado el criterio de belleza como modelo universal eterno, sustituyéndolo con la idea de que debía ser el resultado de la experiencia histórica del individuo en la sociedad. El poeta cubano disiente de este sentido histórico de la belleza porque ve el ideal de belleza vinculado a la fuente primaria de todos los arquetipos, a la madre naturaleza: “¡El poema está en la naturaleza, madre de senos próvidos, esposa que jamás desama, oráculo que siempre responde, poeta de mil lenguas, maga que hace entender lo que no dice, consoladora que fortifica y embalsama!" (VII, 231). El poema está fuera de la máquina racional, del automatismo, de las ideologías degradantes y los sistemas arenosos. Esta idea martiana es absolutamente extraña al ideal moderno que ha cortado su cordón umbilical con la fuente y se aleja cada vez más de la matriz. Sólo el presente -que cobra conciencia del prolongado extravío espiritual de la humanidad- y, además, manifiesta cierto agotamiento del juego de máscaras y el vértigo experimental da muestras de preocupación por los paradigmas perdidos e intenta una reconexión con los modelos de la tradición. Si el poema está en la naturaleza entonces, claramente, la belleza 
no es privativa de ninguna época artística o categoría estética. No es temporal, ni está fuera del hombre. De ahí que en su escritura se detecte lo mismo un estilo clásico, que barroco, que romántico, que moderno o incluso que postmoderno. No discrimina en el uso de los lenguajes, como tampoco condesciende a los rígidos parámetros de los géneros, las escuelas y las épocas. Él los mezcla y hace con ellos un híbrido de acuerdo a las exigencias que demanda el discurso que elige porque "cada inspiración trae su lenguaje".

Si se analiza el ideario poético martiano en su totalidad se verá que en su actitud de revolucionar y reconectar la realidad con la raíz se afinca su idea de la armonía y el equilibrio del mundo, su visión de que lo uno está en todo y que todo tiende hacia la sintesis, de donde se alimenta su cosmovisión ética de la vida. Martí desecha los absolutismos, los relativismos, los centrismos. No es un hombre de escuelas, ni de academias, ni de sistemas políticos o filosóficos. En otras palabras, su eclecticismo cuestiona toda ciencia y todo arte que se erija como verdad hegemónica porque esa idea contiene en sí misma la del extremismo y el absolutismo que son, por definición, ejes del desequilibrio. De este modo los fundamentales conceptos que conforma la modernidad estética al enfrentarse con el corpus de la escritura ética martiana se deshacen, se derrumban como castillo de naipes. Ni comulga con la idea del arte por el arte, ni se refugia detrás de las formas, ni en las ideas apocalípticas, ni acepta la decadencia como sucedáneo o como placer hedónico, ni erige o adora ídolos, ni se encierra en ninguna torre de marfil. Ni siquiera acepta el esnobismo el dandismo y el exhibicionismo de los salones literarios de su época porque no van ni con su temperamento ni con el concepto de honestidad, honradez y responsabilidad que constituyen su actitud vital. La creación 
literaria no era para él motivo de exhibición, ni necesidad de púlpito, sino un servicio amoroso brindado al mejoramiento humano.

Baudelaire, uno de los más admirados poetas modernos franceses y a la vez importante teórico de su estética, dice en "El salón de 1846" que "hay tantos tipos de belleza como modos habituales de perseguir la felicidad" $" 16$, haciéndose eco de la idea de Stendall de que la belleza se define como una promesa de felicidad, con lo cual me parece que Stendall confunde el perfeccionamiento humano con el goce instantáneo. Nada más alejado del ideal de belleza y de goce que tenía Martí. La modernidad erige su idea de la felicidad por un lado en los sucedáneos y por otro en la saturación de las necesidades materiales del individuo. En ambos casos el sentido último es la evasión de la vida cotidiana que se hace una carga cada vez más pesada para el hombre moderno. El ser martiano, como se puede constatar en cualquiera de los componentes discursivos de su escritura, está intrínsecamente ligado a la realidad que está más allá y más acá de la vida material de la sociedad. Su idea de la felicidad y de la belleza está vinculada a la entrega al prójimo, al padecer en aras de aliviar sus agonías cotidianas. Martí entiende con meridiana claridad que si el ser humano no se realiza en la alteridad, o sea no abandona el solipsismo y el egocentrismo racional y se entrega en el deber y el sacrificio a la dimensión del éxtasis del sufrimiento por el otro, jamás alcanza esa mal llamada felicidad de la ideología moderna. Por eso la misión que define para su vida es la de romper tantas cadenas como sea posible en el ansia afiebrada de devolverles a los hombres su verdadera condición humana expropiada y denigrada por las jerarquías del poder. Su misión parte del sacrificio personal: "el hombre debe abrir los brazos y apretarlo todo contra su corazón... todo debe fundirlo en su corazón, como en un 
horno..." (V, 136). Esta idea de la felicidad como sacrificio es la absoluta antítesis de la promulgada por los escritores modernos del goce instantáneo. Su escritura se da como fármaco, no como sucedáneo, ni como pieza de orfebrería. No niega con su escritura el ser, sino que lo afirma. En Martí hay un adelanto de las ideas de Heidegger para quien el tiempo y la existencia humana están inextricablemente relacionados y nuestro ser es un proceso continuo de convertirnos, de existir en una constante proyección hacia el futuro. La obra martiana es una proyección en el crecimiento hacia su "orbe nuevo". Ahora esta proyección martiana no es portadora del ideal de futuro progresista de la modernidad, sino uno que se alimenta del pasado, y en tal sentido podríamos decir que es un futuro anterior. Esta cualidad martiana de anticipación del porvenir ha sido desarrollada con maestría por Cintio Vitier en su ensayo "Martí futuro". El autor señala que entre los grandes servicios que brindó a la humanidad estaba el de su palabra que "tiene el esplendor de una fábula y la categoría de una revelación ontológica”. Pero lo importante para el crítico cubano es que logremos atravesar "el hechizo estrictamente literario de su obra", para así poder:

penetrar en las mansiones interiores de uno de los espíritus más puros y poderosos que han actuado en la historia. Y como el espíritu no puede dejar de actuar, llegaremos a ese centro de su persona que, partiendo de ellos, supera los límites cronológicos de su existencia y se proyecta como heraldo, arquetipo y profecía, igual que los hombres magnos que el concibió en sus grandes retratos, no sólo hasta nosotros, sino hasta donde nuestros ojos actualmente no pueden ver. ${ }^{17}$

A lo largo de todo el ensayo encontramos frases que corroboran el sentido de futuro al que avanza su escritura. Según Vitier el hombre del que Martí habla "es un hombre nuevo, futuro, ecuménico, armonioso por el equilibrio de los contrarios, afincado 
en la tierra y en el hambre de eternidad" (122). La ley del equilibrio es para él ley matriz sin la cual no se pude alcanzar - a través del sacrificio- la síntesis que haga posible inaugurar un mundo de justicia plena, "pues la injusticia, como ya lo vieron los primeros pensadores griegos, no es más que una usurpación del ser" (123). Así, el mundo de síntesis de los sistemas filosóficos, económicos, religiosos que preconiza supera el materialismo y el espiritualismo de su época para encarnar en un estadio superior donde se integran y reconcilian todas las facultades y fuerzas del hombre. De modo que Martí no comulga con la idea historicista de la belleza modernista, ni de su complemento de felicidad objetualizada y, por tanto, degradada en sus esencias. La belleza en él viene acompañada de la virtud, del bien y la bondad: “...el que conoce lo bello, y la moral que viene de él, no puede vivir luego sin moral y belleza" (XII, 414). De ahí que crea en las "sabrosas penas de la virtud" que añade a su idea estética la dimensión del amor. Por eso cree con San Juan de la Cruz que si nos amamos los unos a los otros, Dios está en nosotros. Como nos confirma Fina García Marruz el arte para él no tiene que ver con el artificio, sino con el sufrimiento: "Padecí con amor" es la frase que resume las dimensiones que junta en su trayectoria vital: la palabra y la acción ligadas en el sufrimiento, en el deber, en el ser. Su sentido de futuridad se sintetiza aquí: "Mi verso crecerá: bajo la hierba / Yo también creceré: ¡Cobarde y ciego / Quien del mundo magnífico murmura!". ${ }^{18}$ Estos versos expresan su fe y optimismo en la vida y en la posibilidad inalienable de perfeccionamiento humano.

En el Epílogo a Faces de la modernidad Calinescu concluye que la modernidad es expresión "de autoconciencia y voluntad, y su insaciable deseo de novedad a cualquier costo, puede producir dolorosas dudas y hasta auto-desprecio. La modernidad...se opone 
no sólo al pasado, la tradición, sino también a ella misma" (264). Martí como veremos se opone a lo rancio, lo desvalorizado, pero no se opone al pasado, y menos a la tradición. Incluso en su hermenéutica poética plantea que el verso no debe salir recalentado de la mente, sino como el manantial de las entrañas de la tierra y que la revolución de las letras no debe estar en las formas sino en las esencias. Calinescu plantea que el "polemicismo, la devastadora ironía...son los rasgos más destacados de la modernidad, especialmente cuando asume el rostro furioso de la vanguardia. En sentido general, la cultura moderna constituye lo que he llamado antes una "cultura de crisis" (265). Ya apuntábamos antes cómo el juego de máscaras que ha venido desplegando la modernidad -con la de la ironía como estandarte- alcanza un punto de agotamiento, de vaciedad cuya consecuencia lógica son las más burdas expresiones de la cultura del kitsch. La tradición escatológica de la cristiandad junto a su versión secular del tiempo lineal del progreso origina en el Renacimiento el ideal de la nueva modernidad "como un intento de añadir nuevos valores al hombre insertado en el presente...El cambio, la novedad, lo impredecible, la aventura, la excepcionalidad son algunos de los valores auto-concientes asociados con la idea de la modernidad artística" (265). Esa crisis de valores es anticipada por Martí en su Prólogo al poema del Niágara. Desde dentro del torbellino finisecular es capaz de tomar distancia y pronosticar la descomposición de los valores esenciales la sociedad y diagnosticar la cura para estos males.

Ahora bien esta crisis de valores que señala Martí y que analiza Calinescu continúa hasta hoy sin que se hayan logrado cambios sustanciales, pues el juego de máscaras y la evasión irónica de la estética moderna y invención postmoderna autodestruyen la institución crítica que debe enfrentar, desde la ética, su contraparte 
burguesa, permanente impedimento a ese cambio de valores. Por el contrario la modernidad burguesa ha ido adquiriendo mayor hegemonía desde sus días inaugurales ya que también ha convertido los disfraces en método efectivo. Martí, después de practicar su excavación arqueológica en el cuerpo de la sociedad moderna nos advierte que los cambios han sido hasta ahora de apariencia y deben comenzar a ser de esencias. Esta crisis de valores conduce irreversiblemente a la cultura de la decadencia que tanto erizaba a Nietzsche puesto que su forma de manifestarse es el disfraz. Para el filósofo alemán, "la estrategia de la decadencia es típicamente la del embustero que engaña imitando la verdad y haciendo parecer sus mentiras más creíbles que la propia verdad". Y añade que a causa de "su maestría en el arte de la seducción, es capaz de convertir la debilidad en fortaleza; el agotamiento en éxito; la cobardía en coraje. La decadencia es peligrosa porque siempre se enmascara de lo opuesto" (180). ${ }^{19}$ En consecuencia esta burda mascarada ha corrompido el gusto y, con ello, el sentido de apreciación de la belleza. Sin embargo se vende como gusto superior, y manipula la realidad para que su corrupción sea aceptada como ley y expresión de progreso. El espíritu de la decadencia para el filósofo alemán es tan corrosivamente engañoso en su modo de desdibujar su verdadera entraña que "falsifica la perspectiva normal y hace ver sus propias consecuencias como sus causas" (183). Tenga Nietzsche razón o no en todas y cada una de sus apreciaciones en torno a la decadencia y crisis de la cultura moderna de occidente -aunque el tiempo ha venido a corroborar estos criterios- lo cierto es que Martí llega a similares conclusiones $\sin$ que exista evidencia alguna de contacto entre ambos. Igualmente los principales críticos y teóricos del $\mathrm{XX}$ han llegado, por vías diferentes, a las mismas conclusiones. Pero la evidencia de esa decadencia no es ni siquiera una 
cuestión de debate o especulación artística o filosófica. Quienes vivimos insertados en la modernidad somos asaltados constantemente por tales expresiones en todas las formas imaginables; en el arte y la literatura, en el cine, la televisión, la radio, la arquitectura, el diseño industrial, los objetos, los gestos, las palabras, los discursos, etc. Las expresiones de la decadencia estética son un testamento vivo, convivimos con ellas. Asistimos escandalosamente -y a pesar de las advertencias de Martí, Nietzsche, Benjamín, Adorno, Horkheimer, Gadamer y otros- en la post-modernidad a la apoteosis del mal gusto y a una masificación de la parodia y el Kitsch "y Kitsch es verdaderamente la parodia total, parodia de la tradición y parodia de la ruptura del modernismo con la tradición y finalmente parodia de la parodia del modernismo sobre sí mismo" (265).

¿Al final qué nos queda?, podría preguntarse el lector moderno. La conclusión lógica que se deriva del vano intento de disfrazar la realidad con falsos dioses, falsos profetas, falsos ídolos es la confrontación del ego racionalista con sus propios fantasmas. Lo quiera reconocer o no, la modernidad estética se mete en un callejón sin salida en su juego de máscaras delirante y llega al final a un estado de absoluto agotamiento. Ni el cambio de nombre, ni el cambio de signo, ni el disfraz le han permitido escapar a su propia red de evasiones. La definición de Baudelaire -concluye Calinescu- de que la modernidad es la habilidad de deleitar sensual y estéticamente en el instante fugaz del presente es matemáticamente exacta. Pero en la realidad "el presente es un instante de cero duración. Como expresión de la autoconciencia artística, la modernidad no puede evadir el drama metafísico del goce espontáneo de pura transitoriedad que termina en una súbita confrontación con la nada" (268). El pensamiento estético martiano -como hemos dicho- se opone a estos criterios pues ni la máscara, ni la parodia, ni el goce fugaz, ni el 
ni el disfraz, ni la seducción, ni la ironía, ni la sensualidad desnaturalizada entraban en el horizonte ontológico o epistemológico de su escritura ética.

\section{La literatura como servicio. Deber y verdad}

Martí no es -tal y como anunciamos al inicio- un literato en el sentido clásico del término, o en el mismo sentido en que lo entiende la institución moderna del arte, es decir, no es un hombre de letras. Esto queda definido por él en carta a Bartolomé Mitre ${ }^{20}$, en la que se disculpa por la demora en contestar su correspondencia: "No lo achaque, por Dios, a informalidades de gentes letradas, que en esto no fui nunca, ni quiero ser, gente de letras" (IX, 17; énfasis mío). La multiplicidad de discursos que conforman su escritura y la índole simbólico-metafórica y arqueológica de su pensamiento le otorga a su palabra un espesor que desborda los marcos epistemológicos de la institución literaria moderna. Para confirmar lo anterior sirvan de ejemplo las siguientes palabras de Manuel Gutiérrez Nájera, iniciador de la prosa modernista hispanoamericana ${ }^{21}$ quien dice que:

Martí, cuyas ideas no podemos seguir a veces, porque sus ideas tienen las alas recias, fuerte el pulmón y suben mucho; Martí, en cuyo estilo mágico nos solemos perder de cuando en cuando, como Reynaldo en el jardín de Arminda, o como el viajante intrépido en una selva virgen; Martí para escribir La edad de oro, ha dejado de ser río y se ha hecho lago, terso, transparente, límpido. Lo diré en una frase: se ha hecho niño...un niño que sabe lo que saben los sabios, pero que habla como los niños. No es Hércules hilando a los pies de Onfalia: es Hércules jugando con la reina Mab. (72)

Al poeta mexicano el estilo martiano se le hace demasiado tupido, pero a la vez tiene una claridad y una sencillez sorprendentes, cualidades que suelen ser excluyentes en 
una escritura, pero que en él coexisten de modo singular. Sin embargo, al notar estas dos formas de tan disímiles de la realizarse la palabra en Martí, nos da otra de las características distintivas de su escritura: su capacidad de transfundirse en discursos de índole muy diferente. Gutiérrez Nájera compara la prosa barroca de Martí en sus ensayos o crónicas, cuyos períodos suelen, a veces, extenderse más allá de una página con esta otra prosa llana, sencilla, transparente, sosegada de La edad de oro. "Lo suyo es el mayor de los equilibrios posibles entre la pasión y la forma. Espontaneidad y exquisitez; raro equilibrio" $(246)^{22}$. Martí más que representar la realidad -modo predominante de la episteme de su época- busca problematizarla e interrogar los signos, llegar al corpus subyacente en las profundidades de las cosas, donde yace el verdadero sentido. Esta manera de interrogar la realidad será la tónica que caracterizará la crítica contemporánea, después de los aportes de Nietzsche, Freud, Marx y Jung. En otras palabras, su lenguaje es auto-referencial y no busca recrear al sujeto, sino ejercer sobre él una influencia de transformación, entrar en la médula de su existencia o en la palpitación constante de su ser esencial. De ahí que el ser del lenguaje martiano se vuelva sobre sí mismo y encarne en la acción de su propio sujeto, como ser vivo. En ese interpretar simbólico de su palabra subyace la imagen indeterminada de la posibilidad, es decir, la presencia palpitante del azar y el cierre de la lógica cartesiana.

La propia inestabilidad de la institución racional y la inoperancia de ciertos proyectos de la modernización, abren para Martí -que desconfiaba de la infalibilidad de los metarrelatos- un horizonte soñado de posibilidades donde operar el verdadero sentido de literatura que estaba en el substrato de su escritura. La recia arquitectura de su médula arcaica, cerrada a la precariedad de los sistemas de su época incierta, lo llevan a no 
alquilar su saber, ni coquetear con lo extemporáneo pues su mirada órfica y su escritura ética encuentran motivos de mayor nobleza que sobrepasan la fatalidad exterior, motivos que escarban en los zócalos más profundos del alma. De modo que él transgrede las fronteras de la institución literaria con la autonomía de su lenguaje, no sólo porque desconfía de las teleologías, sino porque además desautoriza el discurso progresista mecánico. Le interesa más interrogar al misterio, a lo incondicionado, en desenterrar las voces silenciadas, las lenguas olvidadas, los textos incinerados por la razón. En tal sentido resulta interesante la valoración que Ramos hace sobre la resistencia que su escritura ofrece a los "flujos de la modernización" y como se muda a los "exteriores" de la institución discursiva moderna, lo que llamo los intersticios del sistema o los desbordes de su logos hacia la periferia.

Su economía será, por momentos, un modo de otorgar valor a materiales palabras, posiciones, experiencias- devaluados por las economías utilitarias de la racionalización. Si para los letrados iluministas la escritura era una especie de máquina que pretendía transformar el "caos" de la "bárbara" naturaleza en valor, en sentido subordinado a los dispositivos de la ley, para Martí la literatura se define como crítica de esa zona dominante del proyecto modernizador. La literatura desliza su mirada hacia la turbulencia, hacia la irregularidad, en contra de las "redenciones [...] teóricas y formales" privilegiadas por el sueño modernizador: "Una tempestad es más bella que una locomotora". Allí donde se detiene el curso de la máquina iluminista, cobra cuerpo la nueva autoridad literaria. En contra del "bisturí del disector" - del positivismo oficial de la épocaMartí propone la prioridad de un saber basado en "la ciencia que en mí ha puesto la mirada primera de los niños". Se trata, en fin de una mirada originaria. $(10-11)^{23}$

Es la mirada que vuelve a encontrarse con el origen y por tanto quiebra el horizonte cerrado de la racionalidad. Es interesante notar que Martí no ve en la naturaleza ese "caos" de la "Ilustración", ni tampoco el taller donde ensayar sus Franquesteins. Él 
coloca el poema en la naturaleza, que es la belleza eterna del principio, la que contiene en sí misma el equilibrio, la proporción y la armonía. A esta belleza le añade la bondad, pues para él eso es lo que ésta produce en el interior del sujeto. Así entra en el ser el elemento del bien, no por la vía del dogma cristiano, sino por la vía de la naturaleza. De modo que con estas ideas desacredita ese concepto moderno historicista de belleza. A la vez pone la idea de bien, o sea bondad, por encima de la idea de felicidad que Baudelaire asocia con la belleza. Finalmente agrega la idea de lo justo, al margen de la institución jurídica del estado moderno. En síntesis: belleza, bondad y justicia son manifestaciones de los "exteriores" de su escritura situadas en las antípodas de la modernidad. Con ellos se remonta a un remotísimo pasado cuando estas manifestaciones estaban unificadas en el mito y el símbolo, cuando la poesía instauraba la verdad en el mundo. A la locomotora que es el símbolo más alabado del progreso en su época -y a la vez el más agresivoopone la belleza natural de una tempestad. Esta idea se encuentra igualmente en su crónica sobre "El terremoto de Charlestone" donde crea imágenes con evidente sentido de oponer a la maquinaria tecnológica, la fuerza de la naturaleza. Una locomotora viene alegremente silbando y es lanzada por el terremoto a un estanque como si fuera cualquier rama de árbol, como si la naturaleza, angustiada de tanta barbarie mecánica, se sacudiera de encima el progreso.

La literatura para Martí fue un deber, un servicio que brindaba a sus semejantes, un acto de amor y de "fe" y una búsqueda constante de la verdad y de las "esencias" del ser. De ahí su convencimiento de que "no merece escribir para los hombres quien no sabe amarlos", a despecho de sus maldades, sus fealdades y sus miserias. La palabra -en consecuencia- debe ser un vehículo para el mejoramiento humano, para elevar al hombre 
por encima de sus miserias, que son las miserias de todos. Esta es otra marcha a contracorriente de la modernidad. No cree que la literatura debe ser sólo reflejo del acontecer, sino que además debe penetrar las contradicciones aparentes para unificar lo dispar y abrir nuevas fuentes de equilibrio y bondad. Por eso protesta contra esos intelectuales que sólo ven las manchas y se regodean en lo feo, sucio y mísero de la vida, sin ver que "Todo es hermoso y constante / Todo es música y razón / Y todo como el diamante / antes que luz, es carbón". ${ }^{24}$ Esos poetas lacrimógenos deben alzarse de sus quejas a ver el concierto majestuoso de la vida del universo: "el hombre debe abrir los brazos y apretarlo todo contra su corazón... todo debe fundirlo en su corazón, como en un horno..." $(\mathrm{V}, 136)$ porque en su fragua es el corazón primero y la razón después. Martí entiende que la literatura es más importante que la historia y que la poesía puede escrutar el misterio mejor que la lógica y la ciencia. En su cuaderno de apuntes número 18 deja escrito lo siguiente: "Emerson se anticipó a Darwin. La poesía vio antes: se anticipó en verso. And striving to be a man, the Worm / Mounts through all the spires of form (XXI, 191). Así ve el proceso de evolución en las imágenes emersonianas. Para él la primera ley es el amor, Ia única que entiende la dimensión del sacrificio. Su mensaje es claro: hay que abrir bien los ojos y entender que las bruscas transformaciones socio-políticas y económicas no deben dar pie al coqueteo impuro de las plumas con las veleidades del poder y la riqueza. En Odio el mar dice: "Lo que me duele no es vivir: me duele / Vivir sin hacer bien. Mis penas amo, / Mis penas, mis escudos de nobleza. / No a la próvida vida haré culpable / De mi propio infortunio, ni el ajeno / Goce envenenaré con mis dolores. / Buena es la tierra, la existencia es santa" (104). Y en carta a su madre dirá: “...crea que jamás saldrá de mí corazón obra sin piedad y sin limpieza... No son inútiles la 
verdad y la ternura..." (XX, 475). Su intención es -como apuntamos- desacreditar los discursos-fragmentos que instituyen verdades a medias que distorsionan la realidad, afectando así la visión integradora del ser. En su ensayo sobre Whitman se pregunta:

¿Quién es el ignorante que mantiene que la poesía no es indispensable a los pueblos? Hay gentes de tan corta vista mental, que creen que toda la fruta se acaba en la cáscara. La poesía, que congrega o disgrega, que fortifica o angustia, que apuntala o derriba almas, que da o quita a los hombres la fe y el aliento, es más necesaria a los pueblos que la industria misma, pues ésta le proporciona el modo de subsistir, mientras que aquella les da el deseo y la fuerza de la vida. ¿A dónde irá un pueblo de hombres que hayan perdido el hábito de pensar con fe en la significación y alcance de sus actos? (XIII, 135)

No sólo cuestiona el saber de su época, sino además inserta en la institución literaria criterios que persiguen la unificación de los discursos, la síntesis del saber. Literatura e historia, libertad política, prosperidad económica y libertad espiritual son ejes de la misma esfera, desencajados por una tradición que ha ido minando, en su trayecto lineal, sus propios puentes y por lo tanto sepultando fragmentos de historia vitales a la reconstrucción de la esfera primordial. Hay un antecedente en Emerson -nos recuerda José Ballón- ${ }^{25}$ cuando en 1837 viendo el efecto que la economía de mercado trae a la sociedad, y especialmente al poeta, nos dice: "Anda por el mundo la noción que el intelectual debiera ser un recluso, un valetudinario, -incapaz para los trabajos manuales o para el trabajo público...Los así llamados "hombres prácticos" se mofan de los especulativos, como si por especular y ver, no pudieran hacer nada más" (17). Cincuenta años después Martí retoma la idea, a propósito de su semblanza de Whitman, en quien admira al "hombre natural" de la tierra del norte. A quienes han difundido esa noción de la poca validez del trabajo intelectual Martí llama ignorantes, pues entiende que el 
alimento espiritual que produce el poeta es tan vital o más para la salud y equilibrio de los hombres que el de la misma industria. Hombres vacíos, presas fáciles de la manipulación ideológica y política, pastos de la corrupción, del robo, de la violencia, del fraude, de la mentira. A esos hombres quiere salvar Martí de tal descomposición "porque de tal modo están acostumbrados los hombres a la servidumbre, que cuando han dejado de ser esclavos de la reyecía, comienzan ahora, con más indecoroso humillamiento, a ser esclavos de la Libertad" (VII, 237).

Al sentido práctico, al empirismo clásico de la ciencia moderna, al pragmatismo exacerbado por el progresismo industrial, opone el sentido holístico de equilibrio, de equidad, de síntesis del saber. "Menguada cosa es lo relativo que no despierta el pensamiento de lo absoluto. Todo ha de hacerse de manera que lleve la mente a lo general, a lo grande. La filosofía no es más que el secreto de la relación de las varias formas de la existencia" (VII, 231). El espíritu y la materia forman una unidad, como muy bien sabían los antiguos. Cuando se quiebra esa unidad sufre el hombre, la comunidad, la sociedad, la humanidad toda. Se vuelve la tierra "una vasta morada de enmascarados" y de "caballos embridados" que siguen a reyes, a Mecías o a tiranos de cualquier calaña. Concluyo este fragmento con un pensamiento suyo que precisa el carácter y el valor de la literatura en los tiempos modernos:

La literatura que anuncie y propague el concierto final y dichoso de las contradicciones aparentes; la literatura que, como espontáneo consejo y enseñanza de la Naturaleza, promulgue la identidad en una paz superior a los dogmas y pasiones rivales que en el estado elemental de los pueblos los dividen y ensangrientan; la literatura que inculque en el espíritu espantadizo de los hombres una convicción tan arraigada de la justicia y belleza definitivas que las penurias y fealdades de la existencia no las descorazonen y acibaren, no sólo revelará un estado social más cercano a 
la perfección que todos los conocidos, sino que hermanando felizmente la razón y la gracia, proveerá a la Humanidad, ansiosa de maravilla y de poesía, con la religión que confusamente aguarda desde que conoció la oquedad e insuficiencia de sus antiguos credos. (XIII, 135. Énfasis mío)

Este fragmento pertenece a los ígneos o hipertélicos por la condensación de las ideas y las implicaciones que estas contienen. Son fragmentos textuales que se multiplican, se enseñan y se esconden, como dice Foucault, o que dicen lo que dicen y lo que no como sugiere Derrida y por el modo en que desbordan la episteme moderna, es válido citarlos. Tratar de explicar todas las conexiones contenidas en los conceptos aquí expuestos tomaría un espacio que rebasa las posibilidades de esta disertación. De modo que referimos lo más sobresaliente. Ya vimos que para él la literatura era superior a la historia, ahora nos dice que produce una paz que es superior a los dogmas y las bajas pasiones - conectadas con el anhelo desmedido de riqueza material que produce la violencia - y finalmente la literatura que hermana la razón con la gracia, -que es el espíritu-, traerá a la humanidad la verdadera y absoluta religión -la ética - que el hombre ansiosamente aguarda y habrá en ella más hermosura y amor que en los vacíos y limitados credos que han acompañado a la humanidad por más de veinte siglos. Más abajo hará, en el párrafo que continúa, la pregunta ya citada antes: ¿Quién es el ignorante que mantiene que la poesía no es indispensable a los pueblos? Y se contesta diciendo que es más necesaria que la industria. Con lo cual termina por descabezar el único Dios que queda vivo en este recorrido, el Dios augusto de la modernidad burguesa, el Dios "Progreso". Hay en estas palabras igualmente una crítica a la especialización de la institución educacional moderna, realidad que sigue tan vigente hoy como cuando él la describió. Así podemos concluir que ni dioses tutelares, ni credos apocalípticos, ni 
estéticas de "aguamiel, ni progresismo teleológico dan para Martí la clave de la existencia. La respuesta a las preguntas de la filosofía, la sociología, la psicología, la antropología, y las ciencias exactas están, para él, en la poesía.

\section{5- Optimismo martiano versus nihilismo modernista.}

Uno de los tópicos que mejor define la estética modernista es el nihilismo y es razonable que así sea si nos atenemos a la lógica cartesiana. Ninguna etapa histórica que se funde en la constante ruptura y la negación del pasado pude encontrar un horizonte ontológico de equilibrio y armonía. Sobre la negación encarnada en la violencia no se puede fundar amor. La ausencia de este sentimiento matriz que de acuerdo a nuestro poeta es lo que lo envuelve todo, tiene que, necesariamente, crear angustia y desolación. La poesía modernista y vanguardista expresan una subjetividad descentrada que no escapa a este sentimiento agónico. El artista, el poeta, acosado por fuerzas ciclópeas que no es capaz de comprender y menos combatir y que lo lanzan al mercado de las fuerzas productivas a convertir la metáfora en mercancía, pierde el rumbo y no ve más que niebla en el horizonte de lo que antes fuera, su cielo despejado. Pasa, de ser un elegido de la tribu, a ser un miembro más del ejército de enmascarados en marcha. Es decir, lo despoja de su prestigio, lo desautoriza y peor, mercantiliza su palabra, lo cual conduce, inexorablemente, a un estado de aturdimiento, de nublazón de la inteligencia y, en última instancia, al sentimiento de opresión y angustia que desemboca en el nihilismo.

En la expresión máxima del nihilismo la modernidad está como Tristan Tzara sabía decir acerca de Dada, contra el pasado, el presente y el futuro. Tal urgencia destructiva ha hecho a muchos escritores de la modernidad 
definirla en términos negativos. Es verdad que la polémica, la ironía devastadora, la autoironía son en muchos casos los más reconocidos rasgos de la modernidad, especialmente cuando asume la cara incómoda de la vanguardia. En sentido general la cultura modernista constituye lo que he llamado una cultura de crisis. $^{26}$

Esta condición existencial se agudiza en la medida en que las fuerzas hegemónicas del poder relegan a la institución artística de su milenaria función de participación en el decir y el decidir el curso de la vida en la sociedad, en la medida en que la palabra poética es despojada de su saber profético, que ahora es otorgado al discurso científico. Para los escritores hispanoamericanos este sentimiento es doble: lo es por razones históricas y lo es por razones estéticas. Los poetas del continente son herederos de una hibridación cultural en la cual uno de los elementos ha sido descabezado por la conquista y la colonización europea. Sin embargo, al sacudirse los cuatro siglos de colonialismo que sobre ellos pesaba, aflora un optimismo por la vida nueva, libre, que promete un futuro luminoso. Este optimismo dura poco. Al montarse en el carro de la modernidad, -cuyas bases ideológicas tienen la misma raíz que había producido el colonialismo- surge de nuevo el sentimiento de pérdida y fragmentación. Con la irrupción de la nueva sociedad llega también la cultura importada que ya está contaminada del sentimiento de decadencia y pesimismo que Nietszche había previsto. Pero esta segunda oleada europea, que ya incluye la Europa del norte, trae una doble dosis del sentimiento angustioso que expresa el nihilismo; a través de su modernidad industrial y a través de su modernidad estética. Unos versos de Darío en Cantos de vida y esperanza (1906) dan testimonio del estado del espíritu en nuestra literatura: "Ser y no saber nada, y ser sin rumbo cierto / y el temor de haber sido y un futuro terror... iY no 
saber a dónde vamos, / ni de dónde venimos...! Estos versos confirman el cuadro de incertidumbre que vive la intelectualidad en los países hispanos, a tono -según Iván Schulman- con "las fuerzas directrices de una sociedad que iba pasando de modo vertiginoso por las etapas de la modernización económica y social" (49). Más adelante en Las entrañas del vacio puntualiza:

Con el desencanto frente al caos vendrá la alienación del artista. El positivismo, filosofía materialista y a la vez idealista, desde mediados del siglo XIX intensifica el proceso, al someterlo todo -sociedad, familia, religión- al escrutinio de los esquemas ideológicos de Compte o Spencer cuyas preocupaciones van dirigidas al análisis de las características de las etapas históricas de la colectividad. En un ambiente socio-político cuyo énfasis es el desarrollo del sector económico de la sociedad, y para la cual los valores culturales y la función del artista constituyen una preocupación menor, sino nula, el artista siente un desplazamiento que se intensifica con los años, deparándole el papel de un marginado inútil, o de una figura decorativa. (50)

Martí, sin embargo, al haber penetrado los profundos subterráneos del ser y haber creado con sus propias manos una subjetivad resistente a los sistemas e ideologías con una cosmovisión con la que deconstruye el aparato hegemónico moderno, no pude ser víctima de ese sentimiento angustioso porque está liberado de los fantasmas de esos meta-discursos. Su mirada se sitúa más allá del límite que coloca "el monstruo frío" y lo que ve es un horizonte de esperanza. Por eso sale de la literatura de su época lacrimosa y pesimista porque esa institución había sido despojada de la fuerza de su instrumental crítico, de su ideal ético y él necesitaba una plataforma menos vulnerable a estos virus del progreso, una cima donde poder dispersar a los cuatro vientos su palabra fundada en la verdad, inmune al soborno y a las veleidades. Martí comprendió muy temprano en su vida que para poder enfrentar la institución del poder de su época, sin compromisos, en 
"el ejercicio del criterio", debía poder tensar su palabra con materiales éticos resistentes a las máscaras, la evasión, la angustia existencial, el alquiler intelectual. "Para realizarse, en un sentido cultural, sin falsificar la identidad hay que entender, $y$ traspasar las máscaras falsas, y enfrentarse con la historia". ${ }^{27}$ Martí se enfrenta -y de qué manera- con la historia, la cuestiona, la desautoriza, la reescribe. No permite que ésta le imponga su fatum de ángel caído obligado a dar vueltas a la noria con las alas maniatadas en el estiércol como refiere en uno de sus poemas de Flores del destierro. Ni siquiera acepta la misión de Sísifo. Su palabra sobrevuela el discurso de los tenores huecos porque su conexión y su comunión han sido hechas con fuerzas superiores más dignas de la condición humana. Ni siquiera a los 16 años con el pie uncido a un vil grillete, (que lo marca para toda su vida), picando piedras en las inmundas canteras de San Lázaro, deja que entren en él las visiones apocalípticas de su tradición. Estamos frente a un espíritu que ha roto las cadenas del causalismo y la ontología racional y se ha situado más allá del universo newtoniano y cartesiano.

En Martí las expresiones poéticas que son de existencia lo son a la vez de resistencia. Es decir, lo problemático existencial pasa a través del prisma de su visión revolucionaria por lo que su escritura mantiene una posición optimista, contraria al gesto pesimista de los modernistas. En vez de pesimismo, que es descenso, en él hay altruismo, que es ascenso. "De mi, no pongo más que mi amor a la expansión- y mi horror al encarcelamiento- del espíritu humano" dirá en carta a Mitre comentándole sobre sus crónicas sobre la vida norteamericana. No pierde la fe en el mejoramiento humano y esa fe trasciende la fe ciega en el utilitarismo de la sociedad de consumo. Su pensamiento responde más a los arquetipos que a los sistemas con lo cual puede escapar a las 
expresiones de angustia existencial características del modernismo: "...cuando se tienen los ojos fijos en lo alto, ni zarzas ni guijarros distraen al viajador en su camino: los ideales enérgicos y las consagraciones fervientes no se merman en un ánimo sincero por las contrariedades de la vida" (VII, 268).

En su inaugural Ismaelillo dice al hijo: "Tengo fe en el mejoramiento humano, en la vida futura, en la utilidad de la virtud y en ti”. Estas palabras dicen de la visión trascendente de su autor. Quien las escribe es un desterrado, un poeta sin patria, a punto de perder para siempre la única semilla de sus entrañas, su propio hijo, que tiene que sobrevivir en ese "mundo de cartón y gacetilla" con trabajos intelectualmente muy inferiores a su talento, en medio de la orgía mercantil que lo corrompe todo, rodeado de envidia, maldad, traición, en un clima hostil que flagela sus viejas heridas, de un torbellino en el vivir extraño a su ser esencial, lejos de su familia, de sus amigos, de sus palmas. Tal cuadro, que podría muy bien producir la más terrible angustia en cualquier ser humano, en él produce visiones de un futuro de esperanza, amor y bondad y abren las sendas del sacrificio, que son en él escalones hacia la redención y el éxtasis. Aunque espantado de todo lo que ve a su alrededor se refugia en la sangre nueva, en la semilla que germina y ve más allá de su horizonte una claridad que le habla de concordia y hermosura. Ese fruto suyo es el futuro. Ha convivido con los hombres en diferentes latitudes y paisajes y ha sido testigo de sus vilezas y fealdades, pero no es un hombre que tropieza con la primera valla y desfallece. Él ve por debajo de la piel del hombre y de las ciudades y sabe leer en la gramática profunda de la condición humana. Por eso su mirada penetra los intersticios de las vallas, mira por entre las junturas y lo que ve es un mundo reconstruido en una nueva fragua, con "nuevos altares" Su fe en el mejoramiento humano 
es inquebrantable. Su convicción de que el cultivo de la virtud es esencial al florecimiento de la grandeza es absoluta.

Pero este año de 1882 es importante en el arranque de su definitiva cosmovisión. Ha concluido ya su periplo por el mundo y comienza la producción de sus textos fundamentales, el primero de los cuales es este hermoso librillo de poemas, cuya revolución es de ideas, no de formas. Los poemas del libro vienen en modos clásicos. Es sumamente significativo como el libro que revoluciona la poesía española en el centro mismo de la oleada de modernidad que condena todo lo clásico, está escrito con estrofas clásicas. Esto dice mucho de la naturaleza de la personalidad martiana. Su problema es ir a la raíz porque allí está el hombre. Y como ha hecho de su misión fundamental abrir nuevos horizontes al ser humano y sacarlo del mal gobierno que ahoga y sofoca todas sus fuerzas vitales, no se detiene en las ramas. No escribe una poesía de apariencia que exprese el vacío existencial transitorio de su época, sino una poesía telúrica comprometida con "los pobres de la tierra" que toca fondo en los problemas vitales del ser. Entiende que es indispensable "reconocer lo inescrutable del misterio, y obrar bien, puesto que eso produce positivo gozo, y deja al hombre como purificado y crecido" (XXIII, 317). Es decir hay límites al conocimiento del hombre -como había poetizado Sor Juana en Primero sueño en el XVII- hay una parcela de misterio a la que el ser no pude acceder que está en la raíz de la idea de Dios. Lo importante es poder hacer, con la parcela otorgada un jardín y plantar rosas, pero también actos de buena voluntad porque eso es lo que nos aproximará a lo que está del otro lado del muro.

En los poemas del libro hay una lucha de las impurezas contra la pureza. El hijo le proporciona las fuerzas para seguir su marcha ascendente y para enfrentarse con los 
"tábanos fieros" y en su camino hacia la luz le nacen alas. Cuan diferente es toda la simbología del Ismaelillo, tan desbordante de fe, de esperanza, de optimismo en el futuro, y de imágenes de raíz ética, si se compara con esa otra poesía lacrimógena, falsa, inútil, “con que los orífices del verso parisiense entretuvieron estos años...el vacío ideal de su época transitoria. En el mundo, si se le lleva con dignidad, hay aún poesía para mucho; todo es el valor moral con que se encare y dome la injusticia aparente de la vida". ${ }^{28}$ Este pensamiento martiano contiene las ideas claves con las que disiente de las actitudes complacientes y escapistas de la modernidad. El fragmento concluye diciendo que: "mientras haya un bien que hacer, un derecho que defender, un libro sano... una mujer buena, un buen amigo, tendrá vigor el corazón sensible para amar y loar lo bello...de la vida, odiosa a veces por la brutal maldad con que suelen afearla la venganza y la codicia" $(V, 221)$. A esa estética de los malabarismos lingüísticos de los orífices del verso, opone su contramodernidad ética porque sabe domar las injusticias aparentes de la vida.

Versos libres ${ }^{29}$ cuyos poemas comienzan a fraguarse alrededor de este mismo año y que constituyen una poetización de las crónicas norteamericanas, es un libro transido de dolor, de frustración intensa, pero a la vez de optimismo, de esperanza, de posibilidades futuras. No se regodea en las desventuras personales, sino que después de los duros golpes, se reconstituye, junta sus pedazos y vuelve a la batalla cotidiana. Hay constantes referencias en él a la caída, la muerte y la resurrección. Porque ha entendido esos estados del alma y la dimensión del sufrimiento, entiende que el dolor ha de ser "pudoroso". En Pollice Verso, a la imagen de "ojos viscosos" opone la imagen de la "paloma blanca". Es decir, al vil, al que se arrastra y dobla la cerviz para que lo enyunten y opriman, opone la imagen del libre y noble gesto del que sube con sus alas. Y aclara que el mundo tiene sus 
lacras, pero eso no justifica el mezclarse en ellas porque bien se puede pasar "sereno entre los viles." Convierte su dolor en himno. Si bien ha sido víctima del presidio, del odio, de "la costra tenaz del coloniaje", no actúa como víctima. Él ve y como veedor entiende que la vida no es "Copa de mago que el capricho torna / En hiel para los míseros, y en férvido / Tokay para el feliz: la vida es grave" (62). Sabe que la resignación es el primer paso a la tumba y que los pueblos resignados no pueden ser libres. Por eso dice: "¡Alza, oh pueblo, el escudo, porque es grave / Cosa esta vida..." (63). Y no habla sólo a sus hermanos, habla al hombre todo, a toda la raza. Juzga vil al que esquiva sus deberes y va a morir "de su aroma ociosa el pecho atravesado" (referencia a los falsos rimadores, esclavos de modas ajenas) porque entiende que "Mientras más trabas rompe el hombre, más cerca está de la divinidad germinadora [...] del Gran Semi sembrador de la América Nueva" (Vitier, XII). El optimismo martiano se expresa cuando, a pesar del sufrimiento y la angustia que lo cercan dice: "Alegremente / El peso eché del infortunio al hombro" (71) y sigue porque es un hombre ardido de amor al prójimo a quien entrega su palabra encendida. El poema además refiere la idea, recurrente en Martí, del dolor, pero a ella se refiere como "las sabrosas / Penas de la virtud..." porque nunca da "al olvido / Las armas del amor" (72) y si el sacrificio y el dolor van de la mano del amor entonces puede entenderse porque son virtuosas esas horas de pena.

En "Estrofa nueva" dice que cada cual es autor de sí mismo y aunque las "vallas rotas" nos flagelen al paso hay que cantar: "Aunque las hidras nuestro pecho roan" la vida y el universo siguen siendo hermosos. Vuelve, de este modo, a su optimismo heroico, demostrando ser un hombre cuya visión se eleva por sobre las vallas del materialismo inútil. Observa la muchedumbre colosal y ve entre la fealdad y la miseria la 
hermosura: "Los niños, versos vivos, los heroicos / Y pálidos ancianos... los hombres victoriosos" (92). Después uno de los versos más hermosos y audaces de todo el poemario: "...el mundo / De minotauro yendo a mariposa" (93) de esencias vanguardistas. Hay que ir de lo proteico a lo acabado y hermoso; de la raíz al ala. Su verso ve el laboreo del mundo, el callo, la joroba, el rostro tiznado de la mujer, el niño tierno que pregona sobre la nieve noticias que lo ignoran y el obrero en la fragua convirtiendo su sudor en míseras monedas. Ve que el hombre es esclavo del hombre en un laberinto oscuro que no acaba, pero también ve que el hombre se levanta con la aurora y sigue andando y se cuestiona el mundo y el poeta tiene fe en que el hombre se mejora, en que crece, en que "salen de los escombros / Volando las mariposas" (179).

En su incesante trajinar ha recorrido al hombre, lo ha conocido y puede distinguir al honrado del villano. De esa distinción se alimenta su optimismo y se fortalece su fe. En "Banquete de tiranos" aparecen estas dos clases de hombres: "Hay una raza vil de hombres... / de sí propio inflados... / de garra y diente" que son los que semejan fieras salvajes que se reparten a dentelladas las riquezas y esclavizan a los hombres honrados y se pierden el concierto universal porque su codicia los ha dejado ciegos y sordos. A estos brutos "civilizados" se oponen los hombres humildes que dan todo de sí: "Y hay otros, como la flor, que al viento exhalan / En el amor del hombre su perfume" (107). A estos recomienda el poeta no mezclarse en las pompas y los festines de los falsos y ruines como el Pedro de "frutillas secas" el alma llena. Le dice a los buenos que si pueden hacerse en paz, que se hagan en paz, porque las armas del juicio son superiores, ideas que constituyen ejemplos de la visión de esperanza del poeta humanista, el poeta héroe, el poeta revolucionario. Ninguno de los modernistas en lengua española alcanzó a delinear 
tal cosmovisión y a ejercer una crítica tan radical de la institución literaria que los sustentaba. Si lo comparamos con quien se autoproclamó iniciador y padre del modernismo, sin dudas su figura más representativa, podríamos ver con claridad por qué Martí no tuvo nada serio que ver con el modernismo. En carta a Paul Groussac aparecida en La Nación de Buenos Aires, periódico que publicaba las crónicas de Martí que tanto deslumbraron e influyeron a Darío, el poeta nicaragüense declara:

Mi ilusión tiene una magnificencia salomónica. Amo la hermosura, el poder, la gracia, el dinero, el lujo, los besos y la música. No soy más que un hombre de arte. No sirvo para otra cosa. Creo en Dios, me atrae el misterio; me abisman el ensueño y la muerte; he leído muchos filósofos y no sé una palabra de filosofía. Tengo, sí, un epicureismo a mí manera: gocen todo lo posible el alma y el cuerpo sobre la tierra, y hágase lo posible por seguir gozando en la otra vida. Lo que quiere decir que lo veo todo en rosa.

Nadie mejor que él hubiera hecho tan precisa descripción del divorcio entre el arte y la vida, un autorretrato tan esclarecedor de sus desvelos y preocupaciones fundamentales. Le seducen el lujo, el dinero, el poder y a ellos va a través del arte. Está seguro de sus posibilidades y de sus limitaciones. Confiesa no servir para otra cosa que para la creación poética. Por eso allí se detiene, imita a sus maestros franceses y de cuando en vez se repugna con la maldad y la injusticia de este mundo y lanza un grito de protesta, pero luego vuelve a su mundo soñado, a su mundo de cisnes y rosas. "La fuga de Darío es consecuencia y mandato de su criterio estético que se aviene a maravilla con su naturaleza (o arranca de ella), mucho más lisonjera que rebelde" ${ }^{30}$ Es cierto que hay momentos en él de preocupación por el destino de Hispanoamérica, mas su temperamento es escapista. Le interesa el hallazgo formal, la belleza de los parajes 
exóticos, lo inefable, lo intangible y complacer a las muchedumbres con sus rimas. En sus palabras liminares de Prosas profanas se pregunta: ¿Hay en mi sangre alguna gota de sangre de África, o de indio chorotega o nagrandano?" Y él mismo se responde: "Pudiera ser, a desprecio de mis manos de marqués; mas he aquí que veréis en mis versos princesas, reyes, cosas imperiales, visiones de paises lejanos e imposibles. ¡Qué queréis! Yo detesto la vida y el tiempo en que me tocó nacer". ${ }^{31}$ Dice que lleva dentro a Verlaine y su esposa es de su tierra, pero su amante de París. Martí, en contraste, siendo descendiente de español, dice llevar en sus venas sangre indígena. Las palabras de Darío sintetizan con excelencia la estética modernista que según él le tocó iniciar en América. Sería acertado decir -quizás- que Darío representa el paradigma del poeta modernista. En esta frase última se resume el sentido de angustia y de pesimismo presente en los textos de tal estética. La crítica literaria se ha encargado de conservarle un sitio de honor entre los grandes hombres de letras de nuestra lengua. Si embargo sus propias palabras son la mejor expresión para establecer las diferencias estéticas y filosóficas que separan a ambos y que explican porqué Martí es cada vez más un poeta contemporáneo.

Martí, a diferencia de Darío, nunca se consideró un hombre de arte o de letras, ni frecuentó los salones literarios. "Versos: Yo no, -yo sujetaré mi palabra en el destierro, y me dejaré devorar por ella, sin que me seduzca el deseo del brillo, ni me intimide el morir oscuro, ni me arrastre la tentación de dejarla ver, antes de defender ni propagar con ella" (XXI, 390). Utilizó su talento como creador para ponerlo al servicio de causas más urgentes y necesarias en su época convulsa como la libertad de Cuba y Puerto Rico, para impedir a toda costa la aventura imperialista del coloso del norte en tierras de América, para educar como hombres de su tiempo a sus hermanos de raza. Esta actitud vital parte 
de su concepto de la utilidad de la virtud y de su comprensión de la vida y de la historia. Hay tanto elemento superfluo y tanto canto fatuo a la utilidad de la vida material moderna a su alrededor, que decide emplear sus fuerzas en el fomento de las virtudes que hermanan, que levantan al hombre de la servidumbre y lo preparan a sacudirse las cadenas de la opresión, que cultivan la razón y el sentimiento para ser útiles en sus patrias libres. La diferencia fundamental entre ambos es que Martí elige para su expresión la escritura ética, y ese discurso sobrepasa el causalismo histórico. Por eso aunque ve la maldad, ve las componendas del poder, ve lo ruin de los tiempos, su optimismo y fe las pone en el perfeccionamiento humano y el ascenso hacia una nueva era para el hombre. Si Darío se lamenta y detesta el tiempo que le tocó vivir y se considera creador único de un movimiento, y se encierra en su torre de sueños inefables, Martí, en cambio, enfrenta su tiempo con la fuerza noble de su escritura, puesto que para él la literatura no es un fin, sino un medio; porque "el arte es una forma del respeto", es una comunión con el prójimo, es un deber humano, es un servicio entrañable por todos los que sufren: “...yo respeto / La arruga, el callo, la joroba, la hosca / Y flaca palidez de los que sufren". ${ }^{32}$, texto que es un adelanto de la vanguardia poética. Luego seguirá enumerando a los diferentes seres que respeta en la que llama "la casa sin sol", que no es más que la urbe moderna, donde devora "sus ansias de belleza" en empleos inútiles. ¿Quiénes son los venerados por Martí aquí? Los trabajadores, los de abajo. ¡Qué diferente este mundo de los bajos fondos al de princesas y cisnes de mundos distantes. Por ese respeto que siente hacia el otro -ese adelanto martiano al concepto de la otredad-, es lo que lo lleva a decir en "Envilece, Devora" que "piensa / en abrazar, como en un haz, los pobres / y a donde el aire es puro, y el sol claro / y el corazón no es vil, volar con ellos" (224). O sea, quiere 
sacarlos de las geometrías opresivas de la ciudad donde marchitan y llevarlos a la naturaleza, templo de justicia verdadera.

Martí ve que las vueltas están oscurecidas con el polvo del combate que comenzó hace un siglo, y que "el trasegar de los combatientes deja sin rosas los rosales", pero ve también que "en la fábrica universal no hay cosa pequeña que no tenga en sí todos los gérmenes de las cosas grandes". Cuando al hombre se le apagan las estrellas del cielo las enciende en el alma. De ahí, según él, esos poetas "pálidos y gemebundos" y "esa nueva poesía atormentada y dolorosa...desmayada y ridícula cuando la ensaya en sus cuerdas un sentidor flojo, dotado, como el pavón del plumaje brillante, del don del canto" (VII, 224). Más allá de las ruindades de los tiempos que vive cree en "la absoluta bondad de los hombres" y en un porvenir con nuevos altares y nuevos quicios:

...cuando hay tres siglos que hacer rodar por tierra, que entorpecen aún nuestro andar con sus raíces, y una nación pujante y envidiable que alzar, a ser sustento y pasmo de los hombres: ¿será alimento bastante a un pueblo fuerte, digno de su alta cuna y magníficos destinos, la admiración servil a extraños rimadores, la aplicación cómoda y perniciosa de indagaciones de otros mundos, el canto lánguido de los comunes dolorcillos, el cuento hueco en que se fingen pasiones perturbadoras y malsanas, la contemplación peligrosa y exclusiva de las nimias torturas personales, la obra brillante y pasajera de la imaginación estéril y engañosa? (VII, 209)

La mayoría de las limitaciones que según él padece la literatura hispanoamericana están resumidas aquí: la permanencia de valores y actitudes rancias y anquilosadas de la herencia colonial; la ausencia en la representación de los valores autóctonos; la admiración servil de modelos foráneos, sobre todo franceses; el escapismo, el esnobismo, el exotismo y el nihilismo, todo lo cual produce obras apagadas, estériles, aún en los más 
dotados de imaginación y talento. Para él resultaba sumamente necesario que los creadores hispanoamericanos puedan superar ese visión fragmentada de la realidad que entregaba el arte europeo y descubrir en la heterogeneidad y la polifonía de voces de la realidad americana la verdadera sustancia múltiple y amorosa de la belleza, partiendo de la raíz para después alcanzar el ala. Los artistas de América podían contribuir dignamente a crear esa libertad espiritual tan necesaria para el surgimiento de una literatura auténtica.

\section{La fragmentación espiritual. Prólogo al poema del Niágara.}

Con el Prólogo al poema del Niágara llegamos a la estación de la modernidad. El hombre aborda su máquina del tiempo, entre el humo y el estruendo de las locomotoras este nuevo caballo de hierro (y ya veremos más adelante como el tren cambia literalmente la noción del tiempo) y Martí lo increpa así: ¡Pasajero, detente! De todas las posibles palabras del idioma -orador, cronista, obrero, hermano-, el poeta escoge la de pasajero. El interlocutor martiano es un viajero en un incesante ir y venir, en un peregrinar sin destino cierto, atontado por el vaivén de la ola humana que rompe en las orillas del continente y se desparrama por doquier, engullendo paisajes, en busca de su utopía. El poeta le pide que se detenga para que escuche su palabra, en medio de la selva mecánica. Es una manera inusual, pero precisa de comenzar este documento, que será mucho más que la celebración de los versos del poeta venezolano Juan Antonio Pérez Bonalde, a quien menciona a ratos, sobre todo para celebrar el motivo de su canto, el Niágara. Lo que admira Martí no es tanto la excelencia de la poesía, sino el que la inspiración haya sido la naturaleza. No podría calificarse mejor al hombre a quien habla Martí. El hombre 
moderno es un pasajero en el sentido más extenso de la palabra: lo es porque está en constante movimiento huyendo de la miseria, en busca de mejor fortuna, de dioses más tolerantes, de un sitio seguro donde poder juntar sus huesos y reposar para la próxima jornada; y lo es, igualmente, porque todo a su alrededor se mueve, cambia, se transforma. El paisaje también está en constante movimiento. Lo que en el crepúsculo era bosque y misa de pájaros, al alba es avenida, torres de concreto, raíles interminables. El ruido de las máquinas y la fiebre del oro lo devora todo: los árboles sagrados, los animales sagrados, los hombres naturales con sus deidades seculares.

La crítica ha considerado este documento como el manifiesto de la iniciación modernista, por la novedad de la prosa y el vasto análisis que en él hace de la crisis espiritual de la sociedad de su tiempo. Pero es, a todas luces, mucho más que eso. Fina García Marruz cree que es "un texto profético, una meditación sobre el sentido de la vida" y se pregunta si no es, a su vez, en realidad, un texto sobre la resurrección. Creo que es a la vez un laberinto y un aleph. Su límite está siempre más allá de la huella que traza. Su signo esconde entre líneas otro (s) texto (s). Es un texto sobre la naturaleza, de la naturaleza, en la naturaleza. El poeta mira a su alrededor y ve que todo es galope, ritmo acelerado, neurosis colectiva. "Apenas se tiene tiempo para vivir. El cráneo es circo, y los pensamientos son caballos azotados. "La neurosis de París" dicen los diarios de Francia. ¡Por qué no han venido a ver esta otra neurosis” (X, 364). Este paisaje humano desencajado, febril, impermanente, en contraste con el ritmo de la naturaleza es el verdadero motivo de reflexión del poeta cubano. Las almas con quienes viaja van en desconcierto, empujadas en todas direcciones por fuerzas desconocidas, con la fe marchita, con un cielo roto y un horizonte sin rumbo visible. Entiende entonces que es 
necesario una profunda meditación ontológica y epistemológica de la existencia humana. Por supuesto no es una reflexión súbita. Éste poema que prologa le ofrece la excusa que necesitaba para expresar la cosmovisión que viene madurando desde su peregrinaje por Europa y las dos Américas y que hacia 1882 cristaliza. El texto traza un arco que va desde la antigüedad clásica hasta la modernidad y en él reflexiona sobre casi todos los temas concernientes a la vida de la sociedad, en lo económico, en lo político, en lo religioso, en lo estético, pero sobre todo en lo concerniente a las preocupaciones latentes de la existencia humana. El texto muestra, como una de sus finas cualidades, su elan poético, esa prosa poemática martiana tan admirada por sus contemporáneos. Para él la época de tránsito en que viaja, consumida en un afán desmedido de riqueza material no puede conducir al hombre a fin noble alguno. En tal sentido el análisis que aquí produce, además de ser -como digo en otro lugar- una de sus epifanías, es también un texto paradigmático en tanto aquí condensa los conceptos capitales de su cosmovisión.

"Ni líricos, ni épicos pueden ser hoy con naturalidad y sosiego los poetas: ni cabe más lírica que la que saca cada uno de sí propio" (225). La gran confusión viene de ver la inseguridad de la existencia por los cambios constantes que la sociedad industrial con su euforia de "progreso" introduce en la vida cotidiana, la pérdida de la fe y el incesante vaivén de la institución artística.

Partido así el espíritu en amores contradictorios e intranquilos; alarmado a cada instante el concepto literario por un evangelio nuevo; desprestigiadas y desnudas todas las ideas que antes se reverenciaban; desconocidas aún las imágenes futuras, no parece posible, en este desconcierto de la mente, en esta revuelta vida sin vía fija, carácter definido, ni término seguro, en este miedo acerbo de las pobrezas de la casa...producir [...] aquellas dilatadas historias en verso [...] en el reposo de la celda, en los ocios amenos del pretendiente en corte, o en el ancho sillón de cordobán [...] en 
la beatífica calma que ponía en el espíritu la certidumbre de que el buen indio amasaba el pan, y el buen rey daba la ley, y la madre Iglesia abrigo y sepultura. (225-26)

El estado general de desconcierto espiritual conduce a la poesía fuera de la celda, de la corte, del palacio y la lanza a los caminos donde el poeta encuentra que puede andar sin tropiezos porque es el tiempo de "las vallas rotas". Por este análisis llega Martí a un concepto nuevo para la creación artística, radicalmente opuesto al del modernismo, y es el concepto de que la poesía es de todos, una de las ideas paradigmáticas del documento. Más que ser la obra individual del creador encerrado en su torre de marfil, para el poeta cubano es obra colectiva. "Asístese como a una descentralización de la inteligencia. Ha entrado a ser lo bello dominio de todos. [...] El hombre pierde en beneficio de los hombres" (228). Fina García Marruz en su ensayo "Los versos de Martí" ve que entre él y Darío hay una fundamental diferencia en cuanto a la aproximación al hecho artístico. "Darío subraya su participación personal, habla de "el movimiento de libertad que me tocó iniciar", en tanto que Martí insiste en que el genio "va pasando de individual a colectivo"; uno habla de una escuela nueva, el otro de un tiempo nuevo" (251). Pero lo que llama la atención es que ya desde 1880 Martí maneja estos criterios tan contrarios a los conceptos elitistas de los escritores modernos que ven su obra la expresión del genio individual. "Pero la poesía es a la vez obra del bardo y del pueblo que la inspira". Y va más lejos aún al decir que la "poesía es durable cuando es obra de todos. Tan autores son de ella los que la comprenden como los que la hacen" (27-28). ${ }^{33}$ La visión martiana sobre la creación artística tiene un sentido coral, de participación de la inteligencia colectiva. Este concepto nace de su vocación de servicio, de entender que la palabra debe fraguarse 
en su noble aspiración de mejoramiento humano, y eso, nos recuerda García Marruz es "la antítesis misma del modernismo" (249). Esta concepción martiana de la creación poética más allá del individualismo burgués, echa por tierra el tópico de la fama y del genio individual. Ésta, además de ser consecuente con la unidad que predica, en actos y palabras, es esencial a su ideal ético de la confraternidad. El uno habla la voz de todos, y todos vuelven a ser creadores como una vez lo fueron. El hombre recuperado para la poesía, deja de ser mercader o consumidor para encarnar como hacedor.

'Las contradicciones aparentes' es otro concepto importante que maneja Martí en el texto y que no ha sido debidamente estudiado, en todas sus implicaciones por la crítica. Quizás sea esta la razón por la que algunos estudiosos de su obra vean contradicciones en su escritura, o en algunas de las vertientes discursivas de ésta. Pero digo en alguna parte, haciéndome eco de estas afirmaciones, que la martiana es una escritura que tiende constantemente hacia la unidad y la síntesis porque es ley esencial de su pensar. "Como para mayor ejercicio de la razón, aparece en la naturaleza contradictorio todo lo que es lógico" (224). A esta idea vuelve con insistencia en varios lugares, hasta culminar en su clásica frase de "Nuestra América": "No hay contradicción entre la civilización y la barbarie, sino entre la falsa erudición y la naturaleza". Falsa erudición llama a ese conjunto de conocimientos nocivos importados desde Europa, entre los cuales están el racismo, el positivismo, el utilitarismo y el "progresismo teleológico". Propone una "literatura que anuncie y propague el concierto final y dichoso de las contradicciones aparentes..." ${ }^{34}$ En el fondo de este concepto yace la idea de que la literatura puede integrar, para beneficio espiritual del hombre, tanto discurso racional fragmentado, que humilla y avienta las almas sin quicio fijo en el torbellino finisecular, pues ninguno de 
esos fragmentos por sí mismos da la clave del horizonte humano. Es decir, las contradicciones aparentes - propagadas a través de una multitud de discursos falaces que han fragmentado el espíritu humano con tantos dogmas infelices-, pueden alcanzar una síntesis que revele la verdad última del ser y la realidad en la poesía. Es un concepto profundamente revolucionario al que le aguarda larga vida y que sólo hoy comienza a asomar los primeros rasgos de su rostro radiante.

Al comprender que el mundo en el que actúa es uno en tránsito, en que "los ferrocarriles echan abajo la selva; los diarios la selva humana", en que las ideas "nacen a caballo, montadas en relámpago, con alas" un porvenir en la balanza de "una portentosa poesía" era lo único que podía aguardar a la humanidad. Y desde la poesía, con su instrumental analógico, busca el equilibrio y la conciliación entre todas las fuerzas del hombre y la naturaleza, entre lo aparente y lo real, entre la ciencia y el espíritu. "Todo va a la unidad, todo a la síntesis, las esencias van a su ser...un tronco es asiento de infinitas ramas: un sol se vierte en innúmeros rayos: de lo uno sale en todo lo múltiple, y lo múltiple se refunde y se multiplica en todo en lo uno" (XXI, 52). Este pensamiento que es reverberación de otros, sobre todo de sus ensayos "Emerson" y "El poeta Walt Whitman", es central en su cosmovisión y -según Ramos- le permite a Martí sobrepasar las contradicciones de la modernidad y reinsertar la experiencia holistica. Para él hay leyes en la mente lo mismo que en el mundo físico y hay que entender las primeras si no se quiere ver contrarios, donde hay armónicos. Él supera la antítesis entre el arte y la vida -cosa que no pudieron hacer los poetas modernistas, ni los vanguardistas-; supera el historicismo teleológico, y la mayor de todas las antítesis de la modernidad, prohijada al amparo del cartesianismo, la antítesis entre el espíritu y la ciencia. Esta idea de síntesis 
entre los dos mundos que había dividido la ciencia desde el siglo XVII es otra instancia del paradigma de su escritura y lo es tanto y en grado tan admirable que en esa dirección vuelve a encaminarse el pensamiento contemporáneo a partir de los hallazgos de la física cuántica que abre igualmente un nuevo paradigma, cuyas primeras repercusiones en el mundo del arte comienzan a sentirse en los fundamentos iniciales de una estética cuántica que absorbe muchos de los conceptos del mundo de la ciencia.

Hasta Newton la alquimia, la filosofía y la física conviven bajo un mismo arco. Pero en el siglo XVII la revolución científica, sobre todo de la física, tan importante para el racionalismo del siglo posterior, destrona al espíritu en la formulación de nuevas teorías y deifica a la materia. Newton crea un modelo en el que el universo pasa a ser un sistema mecánico, como un gran reloj. Nace la física mecánica clásica. Esta escisión entre espíritu y materia conduce a la fractura de un principio de unidad y armonía que había guiado a la humanidad desde la más remota antigüedad. Esta ruptura descentra la búsqueda del principio fundamental de la existencia. La susodicha revolución científicotécnica, en su avance unidireccional, aleja cada vez más al hombre de las expresiones espirituales, creando un cuadro de profunda inarmonía que desemboca en una crisis de valores cuya manifestación más evidente es la esquizofrenia colectiva, la psicosis general y el desequilibrio emocional creciente en la sociedad industrializada. Esta crisis ontológica surgida por el cada vez mayor alejamiento entre materia y espíritu y hombre y naturaleza, es el motivo fundamental de su reflexión ontológica en el Prólogo al poema del Niágara. Pero la misma reflexión la encontramos enriquecida en esos otros dos ensayos mencionados que también contienen una serie de conceptos paradigmáticos. Emerson es una de las personalidades norteamericanas más admiradas por Martí y en el 
mismo año 1882, a la muerte de éste le dedica uno de sus más hermosos ensayos, semillero de ideas poéticas claves para entender la real dimensión de su visión órfica. En él se pregunta:

\begin{abstract}
¿Y las ciencias? Las ciencias confirman lo que el espíritu posee: la analogía de todas las fuerzas de la naturaleza; la semejanza de todos los seres vivos; la igualdad de todos los elementos del Universo; [...] El espíritu, sumergido en lo abstracto, ve el conjunto; la ciencia insecteando por lo concreto, no ve más que el detalle. Que el Universo haya sido formado por procedimientos lentos, metódicos y análogos, ni anuncia el fin de la naturaleza, ni contradice la existencia de los hechos espirituales. Cuando el ciclo de las ciencias esté completo, y sepan cuanto hay que saber, no sabrán más que lo que sabe hoy el espíritu, y sabrán lo que el sabe. (XIII, 25; énfasis mío)
\end{abstract}

Estas afirmaciones, sobre todo la última, están siendo confirmadas por el nuevo paradigma científico, que como apuntamos inaugura la física y la estética cuánticas. ${ }^{35}$ Este pensamiento es uno de los más revolucionarios de Martí por diversas razones. Primero porque anuncia algo que no comenzará a ser preocupación de los científicos hasta la tercera década del siglo XX. Wolfang Pauly, profesor de física teórica y discípulo de Einstein inspirado por la alquimia, (que hasta Newton se ocupaba del mundo de la psiquis, de los sueños y su relación con la materia, es decir, de la conciliación de los opuestos), trata de establecer una síntesis entre espíritu y materia, entre la física cuántica y la psicología analítica. Para fundamentar sus ideas publica junto a Carl Jung un libro bajo el título Sincronía en el que tratan de religar el mundo del inconsciente con el de la ciencia. Sólo hacia finales del siglo veinte han vuelto a ser retomadas las ideas de Pauly y Jung y los científicos contemporáneos han comenzado a cuestionar la primacía del discurso científico sobre el resto de los sistemas de conocimiento o de aprehensión de la 
realidad. La aleatoriedad o el comportamiento azaroso e impredecible de la materia en el mundo de las subdivisiones cuánticas han hecho a los científicos preguntarse acerca de la infalibilidad del discurso científico y la imposibilidad del dominio absoluto sobre el mundo material. El divorcio entre la ciencia y el espíritu en los albores mismos de la modernidad llevan a la sociedad industrializada, no sólo a despojar al hombre de su alma, (dejándolo en una dolorosa orfandad espiritual), sino a la dilapidación de inconmensurables recursos humanos, económicos, culturales y naturales que han desangrado y aún desangran al planeta en guerras fraticidas que desafían la más sofisticada lógica de la propia racionalidad moderna occidental. Eso es lo que prevé Martí basado en su creencia de la conexión entre todos los elementos de la realidad, su convencimiento de que lo uno está en todo y viceversa. Y lo explica con una exquisita sencillez a través de la misma palabra universo que contiene lo uno (uni) y lo diverso (verso) sintetizado en una sola palabra. Por eso dice que la ciencia va insecteando en lo concreto, va arrastrándose y, en consecuencia, no puede ver el conjunto, sino sólo la parte. El mismo Martí nos dice en una de las Escenas norteamericanas que su método "ha sido poner los ojos limpios de prejuicios en todos los campos, y el oído a los diversos vientos y luego de bien henchido el juicio de pareceres distintos...dejarlos hervir" (IX, 17), para luego de decantado lo aparente, darnos la esencia, la raíz.

A partir del siglo XVII la ciencia comienza su paradigma reduccionista que lo lleva a fragmentar la realidad del universo en pequeños trozos para ser analizados en el laboratorio. De esta manera la visión holística que ha caracterizado el proceso de búsqueda de la verdad por siglos en el que participaba el ser con toda su alma, su intuición y sus sueños, queda excluido. La objetivización del universo, como entidad 
completamente separada de la mente humana, cierra las puertas a la subjetividad en la búsqueda de la verdad. A partir de la segunda mitad del siglo veinte, con Einstein y su Teoría de la Relatividad y la mecánica cuántica, comienza a emerger un nuevo paradigma científico - no generalizado aún, pero que gana terreno- que vuelve sobre sus pasos a la idea de unión de las dos esferas de la realidad: la física y lo psíquica. De este modo la ciencia vuelve a encontrarse con la mística para restituir la esfera. Este paradigma desecha la vieja teoría teológica cristiana de la caída y la redención que denigraba la naturaleza pues lo importante era la fe como pasaporte para un mundo mejor. Al amparo de esta teoría la sociedad occidental podía dilapidar todos los recursos del mundo de abajo, sin respeto por el reino animal o vegetal, considerados inferiores al hombre por esa fe. Como este mundo no es el verdadero, ha sido llevado al extremo de la destrucción, ya que hay uno próximo para las almas puras después de la muerte. Por eso es tan importante este pensamiento de Martí, en cuanto que adelanta, o reinserta en el XIX criterios que habían sido desechados completamente en la aventura del saber. Y esto lo hace en medio de la apoteosis reduccionista que incluso lleva esos métodos, con el positivismo, a la esfera de la sociedad. El impacto de esas ideas europeas todavía hoy se sufre. Martí habla de la igualdad de todas las criaturas de la naturaleza y pone al espíritu por encima de la ciencia al sentenciar que ya el espíritu sabe lo que la ciencia, cuando complete su ciclo y vuelva a morderse la cola, igualmente comprenderá: que el hombre y el universo corresponden a la misma esfera y por tanto la materia y el espíritu no pueden divorciarse sin producir los desquiciamientos, ruindades y cataclismos que ha producido desde que se divorciaron. A esta conclusión llega el poeta cubano, no a través de la ciencia, sino de la poesía. Para concluir digo que el nuevo paradigma científico del 
presente que procura reunificar el mundo objetivo y el subjetivo, con la inclusión de los elementos de lo ético y lo estético, que ya sabía la mística, estaba de igual modo en Martí debido a sus inquietas y eclécticas lecturas. Lo que muchos de los pensadores e intelectuales en su época veían como asuntos separados, distantes y disímiles, a veces irreconciliables, no eran otra cosa que las contradicciones aparentes a las que él alude en varios de sus documentos programáticos. Recurriendo a la síntesis -método de su pensararriba a su cosmovisión del mundo en la que logra establecer la unidad y superar el dualismo platónico que ha caracterizado el pensamiento occidental desde la antigüedad.

\section{La poesía como hermenéutica. Contra el discurso antropocéntrico.}

Martí no sólo introduce el concepto de la necesidad del equilibrio entre la esfera de lo material y lo espiritual, y coloca la poesía en un nivel superior al de la industria- la gran novedad de la época-, sino que introduce igualmente el concepto de que la poesía es la verdadera religión, la verdadera divinidad. La salvación del alma no está en llenarla de falsas pasiones, huecas ideologías, sistemas ineficaces, o "libros de dudas que le alzan muralla”. Se pregunta: "¿Quiénes son esos alcaldes de la mente, que tienen en prisión de dobles rejas al alma...?" La salvación del alma humana está en reconectarse, (una vez libre de todo lo infecundo y vil impuesto por jerarquías indignas), con su divinidad interior y con la naturaleza. En su ensayo de Emerson dice: "Y el hombre no se halla completo, ni se revela a sí mismo, ni ve lo invisible, sino en su íntima relación con la naturaleza" (XIII, 25). Es decir, como hemos visto antes la justicia y el poema están en la naturaleza. Ahora nos dice que lo invisible también está en la naturaleza, "maga que hace 
comprender lo que no dice”. O sea, la belleza, la equidad y lo inefable están en la naturaleza y sólo se rebelan al hombre natural, o al hombre moderno reconquistado para la libertad, que es la religión verdadera. A propósito de Whitman y, refiriéndose a Hojas de hierba, dice: "Sólo los libros sagrados de la antigüedad ofrecen una doctrina comparable, por su profético lenguaje y robusta poesía, a la que en grandiosos y sacerdotales apotegmas emite, a manera de bocanadas de luz, este poeta viejo, cuyo libro pasmoso está prohibido" (XIII, 131). La verdad siempre ha causado terror en las almas empequeñecidas en las viles mecánicas del poder. Pero el "justo" que sabe ver detrás de los engranajes y las pedrerías viene a dar la mano a los pusilánimes, a los cobardes, a los extraviados por el canto de las sirenas porque sabe que "mientras más cadenas rompe el hombre, más cerca está de la divinidad germinadora" y porque "lo excesivo no será, pero lo justo será".

El poeta cubano, "veedor en el fiel de la balanza" avanza por entre los escombros humeantes de su época convulsa y confusa, para traer a sus compañeros de viaje, enceguecidos por el desplazamiento vertiginoso del tren de la modernidad, las nuevas luces, los nuevos credos. Trabaja en silencio deshaciendo las cadenas, las consignas y las modas. Ha visto que "las escuelas filosóficas, religiosas o literarias, encogullan a los hombres, como al lacayo la librea; los hombres se dejan marcar, como los caballos y los toros, y van por el mundo ostentando su hierro"... Pero el poeta "está satisfecho" porque "baila, canta y ríe" de saber que su verso "no tiene cátedra, ni púlpito, ni escuela" (XIII, 131-32). Tarea titánica es esta de enfrentar al hombre con sus antiguos dogmas, sus rancias academias y sus falsos ídolos. Martí aboga por el gesto fraternal y conciliador de la poesía que congrega, apuntala y edifica las almas, esa que abre, después de la hercúlea 
tarea en busca del pan, la comunión y la concordia, la paz y el sosiego del alma regocijada en la música de las palabras. Después de apagadas las explosiones del combate, cuando el ser vuelve del caos exterior a hablar la lengua de paz que yace en la poesía de su ser. "Ganado tengo el pan, hágase el verso".

Así llegamos a la última estación de la modernidad estética donde el poeta desenvaina esa espada y produce la herida más profunda al cuerpo, ya no sólo del modernismo, sino de toda la modernidad hasta donde alcanza nuestra vista. Habrá que esperar a la segunda mitad del siglo XX, con los teóricos del lenguaje, y con la figura de Foucault para que se declare la muerte del hombre y se sitúe al lenguaje en el centro de la epistemología moderna. Pero Martí ya había pasado por aquí y declaraba que el lenguaje del universo era superior al del hombre, frase que no debe entenderse al pie de la letra, sino como sentencia simbólica pues ninguna categoría de la cosmovisión martiana es copia de las categorías filosóficas de la tradición del pensar occidental. Es decir, en el centro mismo de la episteme antropocéntrica moderna, con las vallas del positivismo, del utilitarismo, del pragmatismo y el individualismo desplegadas a los cuatro vientos, Martí -el adelantado- se aparece con su ontología, o más precisamente, con su metafísica éticopoética y produce esta extraordinaria y hermosísima sentencia en su poema "Dos patrias" de Flores del destierro: "el universo / habla mejor que el hombre". Con ella echa por tierra, literalmente de un plumazo, tres siglos de racionalismo antropocéntrico y enciende una de las luces más brillantes hasta hoy encendidas en el firmamento del espíritu humano, al ir más allá del límite que ha situado la filosofía contemporánea: el lenguaje.

Octavio Paz, quien no estudió en profundidad la obra martiana, quizás por ignorar cuanto había desbordado el modernismo y la modernidad, algo que le reprochaba Vitier 
se detuvo, sin embargo en este libro y pudo descubrir este poema de Martí que lo impresionó y que analizó con acierto. Es de lo poco que dejó escrito sobre el poeta cubano, quien fuera uno de los más acuciosos exegetas de la modernidad hispanoamericana, pues como a tantos otros intelectuales del continente, la mina martiana le había estado -por muchas razones que aquí no vienen al caso- vedada. En Los hijos del limo, libro que dedica al análisis de la lírica contemporánea, el Premio Nóbel mexicano hace este muy pertinente análisis del poema "Dos patrias".

Si el principio contiene el fin, un poema de uno de los iniciadores del modernismo, José Martí, condensa a todo ese movimiento y anuncia también a la poesía contemporánea... Poema-monólogo que elude la canción, fluir entrecortado, continua interpretación de verso y prosa. Todos los grandes temas románticos aparecen en estos cuantos versos: las dos patrias y las dos mujeres, la noche como una sola mujer y un solo abismo. La muerte, el erotismo, la pasión revolucionaria, la poesía: todo está en la noche, la gran madre. Madre de tierra, pero también sexo y palabra común. El poeta no alza la voz: habla consigo mismo al hablar con la noche y la revolución. Ni self-pity ni elocuencia: "ya es hora / de empezar a morir. La noche es buena / para decir adiós". La ironía se transfigura en aceptación de la muerte. Y en el centro del poema, como un corazón que fuese el corazón de toda la poesía de su época, una frase a caballo entre dos versos, suspendida en una pausa para acentuar mejor su gravedad - una frase que ningún otro poeta de nuestra lengua podía haber escrito antes (ni Gracilazo ni San Juan de la Cruz ni Góngora ni Lope de Vega) porque todos ellos estaban poseídos por el fantasma del Dios cristiano y porque tenían enfrente a una naturaleza caída -una frase en la que está condensado todo lo que yo he querido decir sobre la analogía: el universo / habla mejor que el hombre. (139-41)

El poeta mexicano detecta en estos versos la culminación del proceso analógico martiano que había alcanzado su cumbre en Versos sencillos (1891). "Dos patrias" es uno de los últimos poemas que escribe Martí y por tanto nos ofrece en él, no sólo la maestría de un creador que ha alcanzado ya el absoluto dominio de su instrumento, sino además la 
depuración última de su sustancia alquímica. Aquí ya ha hecho su oro, su jade, su tela infinita. El poema está despojado de todo elemento retórico y fluye como agua de manantial, con entera naturalidad porque trae toda la sustancia de su fértil cosecha: trae a la vez la semilla y el fruto. Este verso culmina un período extenso de maduración de su cosmovisión analógica en la que ha ido fortaleciendo su convicción de que hay fuerzas superiores al hombre que hablan un lenguaje que el hombre no entiende, pero que en su arrogancia y soberbia -y peor- su sordera, descentra o destruye. La explosión logocéntrica de la modernidad en su esquizofrenia discursiva, junto a su materialismo galopante, alejó al ser humano más aún de su diálogo primigenio con la naturaleza, con las fuerzas cósmicas, con el Universo. Por eso Martí dice que "la luz estorba y la palabra humana". Hay que hacer silencio para que resurjan las voces antiguas, las del Nilo, las del Ganges, las de Copán, silenciadas por los discursos teleológicos de la modernidad y por los dioses apocalípticos de su tradición. Transfiere la palabra al magnífico Universo y pide silencio a las filosofías, las ciencias, las religiones, las políticas, los poderes terrenales.

Algunos podrían pensar que estos versos de Martí no producen un desbordamiento de tal magnitud de la episteme moderna, como afirmo y que podría tratarse, no de una cosmovisión y una certeza, o de una maravillosa intuición poética, sino de una idea aislada o surgida al azar. Para ello habría que cotejar estos versos con otros suyos del mismo poemario o incluso remontarnos a sus primeros apuntes de juventud a fin de encontrar un hilo conductor de esta idea cardinal. La primera referencia de su concepción aparece tan temprano como 1874 en su segundo cuaderno de apuntes: "La ciencia trascendental, existe; pero no existe en el orden intelectual humano" (53). Es 
decir, él entiende a los veintiún años que las leyes que han desvelado a la humanidad y a los filósofos con sus elucubraciones por más de veinte siglos, no pueden entenderse racionalmente. $\mathrm{Y}$ en el mismo cuaderno, unas páginas adelante dice algo que hubiera disgustado mucho a Descartes: "El universo es el principio de los conocimientos humanos" (56). No es el hombre el creador del conocimiento, ni su Dios tutelar el alfa y omega de todo lo que existe, sino la fábrica maravillosa del universo. Ya aquí Martí, por asombroso que parezca, ha desbancado dos de los discursos centrales, no ya de la modernidad, sino de toda la civilización occidental: el cristianismo y el racionalismo antropocéntrico. Después, en otro poema de Flores del destierro dirá: "el hombre pasa / Y queda el Universo" en la lid fecunda de "la marcha mística del cielo" (237). Él ya ve "los hilos, la juntura / La flor del Universo" y por eso puede anunciar, pronta a nacer "una inmortal poesía" (243). Es una curiosa coincidencia que en el ámbito de la física cuántica se maneje el término hilo o cuerda para referirse a las últimas teorías sobre el elegante universo. Concluyo el capítulo con una carta que escribiera Martí a su adorada María Mantilla poco antes de entrar por última vez en la naturaleza cubana, camino de la guerra por la independencia de su patria. Aún en medio de estas circunstancias extremas, encuentra tiempo y sosiego para compartirle sus vivencias y sus enseñanzas, pero donde insiste en la idea unidad y la diversidad del universo:

Leo pocos versos, porque casi todos son artificiales o exagerados, y dicen en lengua forzada falsos sentimientos, o sentimientos sin fuerza ni honradez, mal copiados de los que sintieron de verdad. Donde yo encuentro poesía mayor es en los libros de ciencia, en la vida del mundo, en el orden del mundo, en el fondo del mar, en la verdad y música del árbol, y su fuerza y amores, en lo alto del cielo, con sus familias de estrellas, -y en la unidad del universo, que encierra tantas cosas diferentes, y es todo uno, y reposa en la luz de la noche del trabajo productivo del día. 
Es hermoso asomarse a un colgadizo y ver vivir al mundo: verlo nacer, crecer, cambiar, mejorar, y aprender en esa majestad continua el gusto de la verdad, y el desdén de la riqueza y la soberbia a que se sacrifica. (XX, 219 , énfasis mío)

Este es otro "fragmento ígneo o hipertélico" en el que no sólo hace la crítica a la endeble, falsa y artificiosa poesía de su época que ya aludimos, sino además asciende otro tanto y nos lleva a la poesía que no está ya en la ciudad, ni en los dolores de los "pálidos bardos jeremíacos". Saca aquí la poesía del orden y la cifra y la lleva más allá, hasta el complejo tejido de la red de leyes invisibles que entreteje la vida del universo, que la ciencia intenta descubrir con sus espejos de aumento. Pero más asombroso aún, mezcla esa poesía del mundo y del universo con la naturaleza al hablarnos de la verdad, la música y el amor que hay en el árbol. En una sociedad que echa abajo las selvas para que penetre por ellas el ferrocarril, como falo humeante, violatorio de los montes vírgenes, sagrados de los aborígenes; para un progreso que descuaja de la faz de la tierra civilizaciones milenarias que desconoce de forma bárbara, estas aseveraciones martianas, además de estar muy a tono con las más recientes teorías de la ciencia, constituyen, quizás el avance más radical, no sólo de la teoría estética de su tiempo, sino de todo el pensamiento de la modernidad. Aquí hay una personificación del mundo: verlo nacer, crecer, cambiar y aprender. O más precisamente un reencantamiento del mundo, como si Martí le estuviera devolviendo la magia y el misterio -conceptos importantes para la ética levinasiana- que la máquina y la técnica le han arrebatado y, peor, civilizado. Y como si fuera poco, ver cómo el mundo se sacrifica ante la avaricia y la soberbia de los hombres. Aquí está de nuevo tan vivo como lo estuvo cuando todo en él contenía el espíritu del gran universo, cuando todo era divino. Si esto no tiene resonancias en lo más álgido del 
presente, en el debate actual sobre la dilapidación y deterioro de los ecosistemas del planeta, a que lo ha llevado la embriaguez del progreso material, sostenido por la avaricia de quienes detentan el poder, nada en absoluto lo tiene.

Las teorías de la estética cuántica -que no hemos podido desarrollar aquí- se hacen eco de éstas y de muchas otras de las sorprendentes y reveladoras intuiciones martianas. Para Martí el mundo se cura y se mejora a sí mismo sin la intervención de la mano del hombre porque conoce su verdad que es ajena al derroche y la riqueza material, es decir la idea de la humildad, de la justa pobreza que antes analizamos en Nietzsche, Lezama y Martí. La estética cuántica confirma la intuición poética como una forma de acceder al conocimiento y más al saber. "Coincidentemente es otro poeta, Francisco Thompson quien expresa: 'No se puede arrancar una flor sin perturbar a las estrellas". La estética cuántica confirma además como uno de sus principios epistémicos la "no separación pues no hay leyes autónomas, sino que todas están entrelazadas e interactúan a todos los niveles de la realidad. Igualmente esta nueva expresión del arte confirma el principio de la ubicuidad ya que la física ha demostrado que las partículas pueden estar en muchos lugares al unísono como si tuvieran conciencia de fenómenos que ocurren a gran distancia y anticipan respuestas. Pensemos, por ejemplo en esta estrofa de Martí: "Yo vengo de todas partes / Y hacia todas partes voy / Arte soy entre las artes / Y en los montes, monte soy" de Versos sencillos, poemario en que Martí ha logrado una síntesis admirable de todos los elementos de su cosmovisión y donde la naturaleza y el universo obtienen un singular protagonismo. 
${ }^{1}$ Matei Calinescu. Faces of Modernity. (United States: Indiana University Press, 1977). La traducción es mía. Este libro constituye uno de los estudios más importantes cerca de las diferentes facetas que adopta la modernidad en sus diferentes etapas.

${ }^{2}$ Calinescu, 23.

${ }^{3}$ Calinescu, 29.

${ }^{4}$ Calinescu, 49 .

${ }^{5}$ Cintio Vitier y Fina García Marruz: Temas martianos. Departamento Colección Cubana, Biblioteca Nacional José Martí, La Habana, 1969. Martí ha dicho: "Los que ven mucho de súbito parecen enfermos cuando cuentan lo que ven". YCintio ha escrito: "De hecho el tiempo, como nos señala Hedwig ConradMartius, fluye de la fuente del futuro hacia el abismo de lo que llamamos pasado, siendo nuestra conciencia la marca, la aguja, el gnomom que le da en cada instante la condición de presente; pero son poquísimos los hombres que tienen la capacidad de asumir intencionalmente ese proceso y saturar todo su ser de una calidad intrínseca de futuro, trastornando la marcha habitual del causalismo, el evolucionismo y la dialéctica (estructuras de la voluntad lógica), para identificarse con el espiritu mismo del tiempo" (133)

${ }^{6}$ Calinescu, Faces of Modernity pp. 3

${ }^{7}$ Octavio Paz: Las peras del olmo. (Madrid: Seix Barral, 1990), 100. En "Poesía de soledad y poesía de comunión". Este ensayo fue presentado por el autor en un ciclo de conferencias convocado por la editorial Séneca para conmemorar el cuarto centenario del natalicio de Sor Juana Inés de la Cruz.

${ }^{8} \mathrm{Paz}, 100$.

${ }^{9}$ Fina García Marruz. Temas martianos. 214.

${ }^{10}$ Octavio Paz. Las peras del olmo. 101-102.

"Paz, 101-102.

${ }^{12}$ Daniel Bell. Las contradicciones culturales del capitalismo. New York: Basic Books, 1976. Bell enfoca su análisis en el resultado que se aprecia en el nivel de banalización a que ha llegado la cultura de masas y no en la raíz del problema, o la causa que origina tal resultado, que no es otro que las propias irreconciliables contradicciones de las estructuras dominantes del sistema como tal. 53-54.

${ }^{13}$ Calinescu, 7.

${ }^{14}$ Calinescu, 8 .

${ }^{15}$ Calinescu, 36 .

${ }^{16}$ Calinescu, 46 .

${ }^{17}$ Cintio Vitier. Temas martianos, 121.

18 José Martí. Flores del destierro. Uso para las citas de Flores del destierro la edición de la Poesía completa. Ed. de Carlos Javier Morales, (Madrid: Alianza Editorial, 1995), 214. 
${ }^{19}$ Las ideas de Nietzsche aparecen citadas por Calinescu en su sección The idea of Decadence. 151-211.

${ }^{20}$ Esta carta es de 19 de diciembre de 1882 y en ella Martí se disculpa con Bartolomé Mitre por no haber respondido la carta de éste en el correo anterior y no haber comenzado su colaboración para el periódico. "Pero después de dos años de no ver a mi mujer e hijo, me han venido en estos mismos días, en medio de este crudísimo diciembre, a alegrar mi casita recién hecha, que es toda de Ud. Y primero las ansias de aguardarlos, y los miedos de que no viniesen, y luego las faenas del establecimiento y las enfermedades de aclimatación, -me han quitado el sosiego de espíritu y claridad de mente necesarios para escribir con honradez y serenidad cosas que han de leer gentes sensatas". (IX, 17) Bartolomé Mitre y Vedia es el director del diario La Nación de Buenos Aires, uno de los periódicos más importantes del continente hacia la segunda mitad del XIX y en el cual Martí sostuvo una larga y fructífera colaboración. Allí publicó muchas de sus crónicas y por ellas entró Darío en contacto con la escritura de quien consideró su maestro.

${ }^{21}$ Iván A. Schulman "Estimativa de la prosa modernista" en Martí, Dario y el modernismo, 72. Estas palabras corresponden a un artículo de 1889 escrito por Gutiérrez Nájera a propósito de La edad de oro.

${ }^{22}$ En "Los versos de Martí", Fina García Marruz explora la dualidad sentido/forma en Martí. De igual modo toca en "La prosa poemática de Martí el elemento de la diversidad discursiva del cubano.

${ }^{23}$ Julio Ramos. Desencuentros de la modernidad en América Latina: Literatura y política en el siglo XIX. (México: Fondeo de Cultura Económica, 1989).

${ }^{24}$ José Martí. Poesía completa. Edición Crítica (La Habana: Letras Cubanas, 1993), 236.

${ }^{25}$ José Ballón. Autonomía cultural americana: Emerson y Martí. Pliegos, Madrid, 1986. El autor hace un mesurado análisis de las convergencias entre el pensamiento martiano y el emersoniano. En general del análisis de Ballón se desprende la idea de que la cosmovisión martiana da un giro al encuentro con Emerson. Mas, en realidad, cuando Martí entra en él ya viene con los fundamentos de su cosmovisión. Lo que si es cierto es que el descubrimiento de la obra del pensador norteamericano, reafirmó y enriqueció esa cosmovisión pues en ella entraban también esencias del pensamiento místico de la tradición oriental que ya Martí había explorado.

${ }^{26}$ Calinescu, Faces of Modernity, 265.

${ }^{27}$ Ivan A. Schulman. Las entrañas del vacio: ensayos sobre la modernidad hispanoamericana. (México: Cuadernos Americanos, 1984), 54-55.

${ }^{28}$ A la muerte del poeta cubano Julián del Casal en 1893, Martí le hace un breve homenaje en las páginas del periódico "Patria": "Murió de su cuerpo endeble o del pesar de vivir, con la fantasía elegante y enamorada, en un pueblo servil y deforme"

${ }^{29}$ Todas las citas de sus Versos libres y de Ismaelillo están tomadas de su Poesía completa, Edición crítica, preparada por el Centro de Estudios Martianos. Editorial Letras cubanas, 2001

${ }^{30}$ En José Martí: escritor americano Marinello dedica un apartado al análisis de las actitudes y tendencias del modernismo.

${ }^{31}$ Rubén Darío, Antología poética (Madrid: Biblioteca Edad, 1998), 28.

32 José Martí. Flores del destierro, 242

${ }^{33}$ Del artículo "Poetas españoles contemporáneos" en Obras Completas, (XV, 24). Este trabajo de 1880 es uno de los primeros de Martí en la prensa norteamericana después que fija su residencia en Nueva York. 
Aparecen aquí ya algunos adelantos de las ideas estéticas, que luego profundizaría en el "Prólogo". Se publicó por primera vez en The Sun. Nueva York el 26 de noviembre de 1880.

${ }^{34}$ José Martí. "El poeta Walt Whitman”, 135.

${ }^{35}$ Para una más extensa aproximación a las ideas que explora hoy la estética cuántica y que confirman de manera asombrosa muchas de las intuiciones poética martianas véase el libro The World of Quantum Cultura, ed. by Manuel J. Caro and John W. Murphy (Connecticut: Praeger, 2002), 1-70. 


\section{Capítulo III}

\section{Contra-discurso de la modernidad burguesa.}

\section{La escritura martiana y su discurso anti-hegemónico.}

La cara oscura de la modernidad, según se desprende del análisis de Walter Mignolo en su ensayo "Colonialidad global, capitalismo y hegemonía epistémica"1 es la colonialidad. La escritura ética martiana, en tanto es, en esencia, una escritura anticolonial se da como resistencia y subversión de los meta-discursos de la modemidad burguesa. La contra-narrativa martiana en su vasta formación se erige con el propósito de desacreditar el discurso euro-céntrico universalista, así como su historicismo teleológico y su ideal de progreso tecnológico. Estas construcciones que surgen del estado emergente de la Ilustración del siglo XVIII europeo, tienen sus raíces en el Renacimiento. Este estado burgués que emerge de la Ilustraeión -aunque revolucionario en sus inicios- se va transformando en el proceso de interacción de fuerzas entre los dos mundos que se oponen hasta convertirse en un poder hegemónico absoluto. El viejo régimen que es descabezado por la ola revolucionaria renacentista no se cruza de brazos a contemplar como pierde su poder y sus privilegios, sino que al amparo de la iglesia católica -antigua aliada y quien había perdido igualmente su antigua jerarquía- emprende una contrarreforma y con las fuerzas de la superstición vuelven a imponer el terror de las hogueras. Así el siglo XVII europeo vuelve de nuevo a recrear el paisaje político-social y cultural de la Edad Media. Este enfrentamiento produce una guerra civil -con matices religiosos y sociales- que devasta el viejo continente. Como resultado de estos acontecinientos desplegados en todas las esferas de la vida y que abarcan un período de 
más de tres siglos el nuevo orden que surge trae en sus entrañas todos los signos del absolutismo y de la crisis. Desde sus inicios la modernidad es el resultado de una titánica lucha entre el plano de la inmanencia que había abierto el Renacimiento, -cuyo fundamento es el desarrollo de una subjetividad revolucionaria, libre de toda opresión- y el de la trascendencia que la burguesía retoma del Medioevo, aunque reformula y reconstituye a partir de un nuevo ideal de humanismo definido en términos abstractos. El nuevo estado tiene el firme propósito de reapropiarse del poder entonces en manos de las multitudes. Es una contrarrevolución política, social, cultural y filosófica que persigue eliminar los ideales democráticos surgidos de la certeza renacentista de que el hombre es un ser destinado a la libertad y al desarrollo sin trabas, ni jerarquías de su singularidad y su deseo. De la oposición de estos dos planos emergen dos visiones antagónicas de la vida que vendrán a representar las dos modernidades conocidas: la burguesa y la estética. La primera -que es la que nos interesa ahora- como no puede volver a los estatutos del viejo régimen, ni puede reconstruir el pasado, se da a elaborar nuevas ideologías con las cuales ejercer su autoridad, "y para ello despliega -como mencionamos- un nuevo poder trascendente ejercido sobre la ansiedad y el temor que alienta entre las masas".2 Esa táctica se ha mantenido por los últimos dos siglos en su afán de conjurar cualquier intento de parte de las multitudes de reconquistar el plano de la inmanencia.

Estas dos modernidades -como nos dice Walter D. Mignolo- aparecen en el relato de la Guerra de Treinta Años que libran Inglaterra, Francia y Alemania y que desangra al continente hasta que se firma una paz que es más el resultado del desgaste y la miseria infringida sobre estos pueblos que el deseo de aceptar una "paz humillante" 
condicionada al orden imperial. A partir de este análisis, tanto los autores de Empire, como Mignolo y los más recientes investigadores en el ámbito de la colonialidad comienza a establecer una conexión entre la modernidad y el Imperio Romano, algo que Martí ya había hecho en el silgo XIX al referirse a Estados Unidos como la "Roma de América". Pero Mignolo, va un poco más lejos que Hardt y Negri porque según entiende la reconstrucción del universalismo europeo debe incluir "otro posible relato de la modernidad que ellos dejan fuera en Empire y que "involucra a España, Portugal, los circuitos del Atlántico, el oro y la plata de las Américas, la esclavitud masiva y los Africanos en América además del casi exterminio masivo de los indígenas. ${ }^{3}$ Para Mignolo este fragmento de la modernidad no tiene que ver con la batalla entre la inmanencia y la trascendencia que se resuelve - o mejor sería decir disuelve- en la guerra que el corazón de Europa libra por espacio de treinta años y que establece en su espacio interior - con la complicidad de la ideología cristiana- el poder hegemónico que genera la crisis permanente de la conciencia moderna, algo que Nietzsche subraya con denodado énfasis hacia fines del siglo XIX, y que igualmente en el contradiscurso moderno de la escritura martiana, sobre todo en su idea de que la institución política de la democracia norteamericana padece las mismas lacras de los absolutismos europeos que la nueva etapa afirmaba haber enterrado. Este otro fragmento del que nos habla Mignolo tiene más que ver con "la expansión de la cristiandad, la consolidación del mercantilismo y la articulación religiosa y legal de la colonialidad del poder". ${ }^{4}$ Esta es la modernidad periférica que genera un contra-discurso dirigido a desacreditar el euro-centrismo. En ella Martí establece su espacio contra-narrativo que despliega en dos expresiones discursivas fundamentales: su discurso anticolonial y su discurso antiimperialista. 
Ahora consideremos algunos elementos adicionales que conforman el fenómeno de la modernidad antes de entrar en el contra-discurso martiano. Una época histórica, como sabemos, elabora un tejido discursivo destinado a conformar una plataforma donde poder insertar las doctrinas y las estrategias que constituyen su episteme. La primera estrategia en la concepción de la modernidad hegemónica europea -según Hardt y Negries una conquista de René Descartes.

Aunque Descartes pretendía perseguir un nuevo proyecto humanístico de conocimiento, lo que realmente hace es reestablecer el orden trascendente. Cuando representa a la razón como único medio de mediación entre Dios y el mundo, efectivamente reafirmó el dualismo como el rasgo definidor de la experiencia y el pensamiento. ${ }^{5}$

El espacio que el humanismo renacentista había abierto con el plano de la inmanencia, Descartes lo vuelve a cerrar al reinsertar en la subjetividad el orden trascendente. Así se sitúa como uno de los primeros ideólogos de la burguesía en el principio de la Ilustración. Esta relación entre la intelectualidad y la institucionalidad sienta las bases para la constitución de las estructuras del poder de la nueva clase, y a través de "la formalización de la política, la instrumentalización de la ciencia y la técnica con fines de lucro, la pacificación de los antagonismos sociales". ${ }^{6}$ De esta relación nace la doctrina para el progreso alimentada de una parte con la idea de la infalibilidad de la ciencia y su estandarte positivista y de la otra por la ética puritana del trabajo con su ideología del trabajo como realización de los sueños e ideales de futuro. De este consorcio igualmente emanan los conceptos del euro-centrismo y del universalismo de la cultura occidental así como del historicismo teleológico. De acuerdo con Hardt y Negri hay tres operaciones que se concretan en esta etapa de formación de la nueva episteme: "la exclusión de la 
experiencia en los fenómenos, la reducción del conocimiento a la meditación intelectual y la neutralización de la acción ética en el esquematismo de la razón". ' Estas operaciones asestan un duro golpe a la tradición del pensamiento no racional, a todo ese pensar que el hombre a través de la historia ha expresado en la experiencia, los sueños, los símbolos, la poesía, la alquimia, el amor.

El pensar filosófico contribuye a la solidificación de los criterios progresistas y cientificistas al intentar encontrar una explicación sistemática a la nueva realidad emergente en el período de la Ilustración. Kant, por ejemplo, pone en el centro de su filosofia un sujeto, pero formulado ya con las limitaciones del dualismo cartesiano y con "un indistinto apetito de la voluntad" ${ }^{8} \mathrm{El}$ ideal kantiano se reconoce fundamentalmente en su ansia de trascendencia, desposeyendo a la inmediatez de su valor y su decir en el conjunto hombre-vida. Tiene que venir Schopenhauer para producir la mejor lectura de Kant al reconocer en su filosofía el instrumento que deshace los remanentes de la revolución humanista. Por esta misma razón "reacciona con mayor violencia contra Hegel, a quien llama un 'intelectual Calibán' [pues] encuentra intolerable que Hegel trasforme la pálida función constitutiva de su crítica trascendental en una sólida figura ontológica con tal violencia". ${ }^{9}$ Para los autores de Empire está claro que la filosofía de Hegel revela la intención verdadera detrás de la contrarrevolución ideológica que se da en el seno de la modernidad burguesa y que intenta por todos los medios conjurar las expresiones inmanentes de la revolución cultural renacentista. Del pensamiento hegeliano se desprende que "la liberación de la humanidad moderna puede ser sólo una función de su dominación, que la meta de inmanencia de la multitud es transformada dentro del necesario y trascendente poder del estado". ${ }^{10}$ Si es cierto que Hegel "restaura el horizonte 
de la inmanencia [ésta] es realmente una inmanencia ciega en la cual las potencialidad de la multitud es negada y subsumida en la alegoría del poder divino [...] el poder de la potencialidad está bloqueado, controlado, homogeneizado por la finalidad" ¿Cómo no iba a estar Schopenhauer justamente indignado ante las posturas conciliadoras y la ceguera filosófica de este binomio de pensadores alemanes que se alejaban del hombre para cobijarse en una trascendencia mediatizada a la sombra del poder político? ¿No está acaso aquí el germen de la idea de globalización que aterra hoy a la humanidad en todas sus posibles manifestaciones? Sin embargo hay otra idea que el filósofo alemán añade en la constitución de éste fenómeno y es una nueva concepción del tiempo expresada en su dialéctica teleológica. Esto viene a poner fin al proceso de formación de la base ideológica de la modernidad burguesa. "La modernidad estaba completa, y no había posibilidad de trasvasarla". ${ }^{12}$ Desde entonces el antagonismo de las dos modernidades no ha cesado y su convivencia se expresa en un perpetuo acto de violencia.

El estado moderno se constituye así en el seno de la modernidad burguesa como una entidad en cuyo seno convergen la política y la metafísica. "La política reside en el centro de la metafísica porque la metafísica moderna Europea surgió como respuesta a las exigencias de las singularidades liberadas y la constitución revolucionaria de la multitud". ${ }^{13}$ El estado moderno es la respuesta de la modernidad burguesa a la necesidad de control de las multitudes que deben seguir produciendo -tanto en el seno de Europa como en las colonias- para aumentar las arcas de las élites dominantes y prevenir cualquier forma de organización que pueda retar ese nuevo orden. Las expresiones revolucionarias de la inmanencia quedan subsumidas -según Hardt y Negri- en un aparato político trascendente. Para Hobbes este "Dios en la tierra" asume su trono y se 
solidifica a partir de la idea de soberanía, una construcción que involucra a las multitudes en un proyecto único de defensa de los intereses comunes. Este proyecto, que se da en forma de contrato indirecto está por encima de cualquier necesidad social y, por tanto, la libertad individual se disuelve en los intereses del poder soberano que ejerce su ley. Este poder trascendente, sin embargo, se expresa como representación del cuerpo social, algo que los humanistas con razón consideran una paradoja. "Esta teoría de la soberanía presenta la primera solución a la crisis de la modernidad". ${ }^{14}$ En esta evolución ideológica la modernidad burguesa concibe que la voluntad individual debe ser alienada en favor de la soberanía del estado. De este modo se equipara la soberanía del estado moderno al de la monarquía absoluta.

En esta breve aproximación a la constitución de la modernidad burguesa podemos notar como se forma una cadena de pensamiento en la que participan los filósofos de la Ilustración como los de las primeras republicas a lo que luego se suman las teorías del valor del capitalismo. La conclusión a la que llegan Hardt y Negri es que: "La soberanía europea moderna es la soberanía del capital, una forma de dominio que predetermina la relación entre la individualidad y la universalidad como función del desarrollo del capital". ${ }^{15}$ En esencia, como se desprende de este análisis las formas de expresión de la autoridad y las figuras de gobernabilidad poco han cambiado a lo largo de toda la historia de Occidente desde que aparecen las primeras formas de colonialidad en el seno de la civitas. Las modificaciones han sido de forma, de representación, de organización, pero en el fondo la figura del poder ejercido en forma absoluta, desdibujado, edulcorado, enmascarado, sutilizado es la misma. Está en la raíz del universalismo occidental. Por eso Martí plantea que hasta ahora las revoluciones han sido de formas, pero es necesario que 
comiencen a ser de esencias. Así comienza precisamente a ejercer su contra-discurso ya que es capaz de detectar por encima o por debajo de estas estructuras y de estas figuras de pensamiento sus inconsistencias, sus manipulaciones, sus no declaradas intenciones de alienación de la individualidad que para él resultan ataques directos a las expresiones de la humanidad del hombre. Consciente de estas falacias y fabricaciones del poder declara que la primera tarea del hombre en los tiempos revueltos y brutales de la modernidad, es "reconquistarse para la libertad", constituirse a sí mismo -cosa que más tarde también sugiere Foucautl- más allá del violento engranaje del estado moderno, en la periferia del "monstruo frío".

La oposición martiana a los principios ontológicos y epistemológicos de la modernidad burguesa se da, - como apuntamos- fundamental, aunque no exclusivamente, a través de dos de las más importantes vertientes discursivas de su escritura ética: su discurso anticolonial y su discurso antiimperialista. Ambos fragmentos han sido abordados en extensión por la crítica cubana así como por los estudiosos de su obra fuera de la isla, sin que ello signifique, en ningún modo, que su reservorio de alumbramiento esté agotado. Sin embargo la referencia a ambos discursos en estas páginas sirve sólo el propósito de argumentar cómo ambos se erigen en fundamentos del paradigma de su escritura ética y como ésta desborda - con ellos- la modernidad burguesa. Para 1880, cuando viene a residir a Estados Unidos el capitalismo norteamericano ha alcanzado su etapa monopolista y la hidra corporativa ha extendido sus tentáculos por todo el cuerpo de la institución política. Esta alianza económico-política fraguada a espaldas del cuerpo social, enmascarada en el espectáculo público del sufragio, junto a las promesas de prosperidad y progreso, a la par que traiciona los principios democráticos y el espíritu de 
la constitución, va conformando un poder omnímodo, que destruye poco a poco los remantes de la real participación de las masas en la gestión política del estado.

Martí ve con gran consternación cómo la acumulación desproporcionada de capital en unas pocas manos produce el aumento de las necesidades esenciales de la población y la miseria comienza a asomar su rostro deformado en aquellos quienes producen la riqueza de que se les despoja. Al poeta cubano le perturban las maniobras y componendas que ve fraguarse entre las instituciones del poder en las que se reproducen en el seno de la nueva democracia los mismos vicios de los viejos sistemas y ve que "en vez de robustecerse la democracia y salvarse del odio y la miseria de las monarquías, se corrompe y aminora la democracia". ${ }^{16}$ Esta es la primera conexión importante que el pensamiento político martiano realiza sobre el capitalismo norteamericano. Constituye, a la vez, la primera crítica fundamental al sistema democrático estadounidense que por su novedad y juventud goza de gran prestigio y admiración en todo el Occidente y se considera como lo más acabado del sistema político moderno. Pero Martí, que escarba en las capas del sistema con su "legítima ciencia social" ve que "el carácter norteamericano ha descendido desde la independencia y es hoy menos humano y viril". 17 Para esta fecha (1894) escribe que la república se ha tornado "autoritaria y codiciosa". Volveremos más adelante sobre este texto, pero queda claro ahora que el escritor cubano, aunque es capaz de ver los logros del sistema político del norte, ve también los elementos negativos que dan principio a la erosión de la democracia, y ya que no es víctima del orgasmo histórico de Sarmiento, pude señalarlas de forma clara y digna.

Según Michel Foucault "el poder ejerce su propia eficacia: crea ámbitos de saber, rituales de verdad, campos de realidad; sobre todo "normaliza" -establece normas...". 18 
No elimina las ilegalidades, sino que más bien las administra. Estas ideas explican la eficacia en la operatividad del poder del estado moderno, capaz de asimilar los cambios sociales y a la vez seguir produciendo "ámbitos de poder" y "rituales de verdad" cada día más sofisticados. En esa operatividad descansa el concepto de hegemonía elaborado por Gramsci en las primeras décadas del XX. Dicho concepto ha cobrado relevancia dentro del campo teórico actual por su capacidad de asimilar en él las diversas tendencias ideológicas en pugna que interactúan en el ámbito político. La diferencia esencial en el ejercicio del poder del estado moderno con sus similares antecesores radica en la manufactura del consenso que permite el dominio de las fuerzas vivas de la sociedad con un mínimo uso de las fuerzas represivas en su ejercicio de control absoluto. En Age of Betrayal: The Triumph of Money in America, 1865-190019 Jack Beatty analiza cómo el sistema de partidos le proporcionó a las élites industriales en Norteamérica la cobertura necesaria para establecer sus monopolios sin tener que producir un ataque frontal a la democracia:

El sistema de partidos -la estructura y los términos de la competencia política- aisló la industrialización de la democracia a través de una política de distracción, basada en la manipulación de verdaderos odios y fingidos resultados. 'Los partidos tal como existen hoy son escandalosos impostores y fraudes organizados', un antiguo teniente populista gobernador de Kansas afirmó en 1898 [...] 'Son, o confiables maquinarias de la plutocracia y las corporaciones, o herramientas de los hipócritas y arlequines, y son tan responsables, a través de las decepciones que han practicado y la corrupción que han defendido, por la servidumbre de las masas a los usurpadores plutócratas...' Distracción, decepción, corrupción -el editor omitió solamente fuerza". ${ }^{20}$

Por su parte Martí, quien detecta cómo los monopolios extienden en afiebrada metástasis sus tentáculos sobre todas las esferas de la vida nacional, incluida la política, para él una 
de las maniobras más peligrosas, comienza la producción de sus crónicas. A través de ellas -con la eficacia de su pluma-bisturí- opera profundas heridas en el cuerpo del país y expone los tumores cancerígenos que han venido deformando las estructuras originales de la democracia representativa norteamericana. Estas crónicas constituyen hoy, además de uno de los más agudos testimonios del proceso político norteamericano en su etapa de expansión y crecimiento, una de las más vastas y certeras contranarrativas modernas. La crítica ética, que es el modo operativo de su escritura, va a la raíz de los problemas:

La libertad política, que cría sin duda y asegura la dignidad del hombre, no trajo a su establecimiento, ni crió aquí en su desarrollo, un sistema económico que garantizase a lo menos una forma de distribución equitativa de la riqueza; en que sin llegar a nivelaciones ilusorias e injustas, pudiese el trabajador vivir con decoro y sosiego, educar en honor a su familia, y ahorrar para su ancianidad como el legítimo interés de labor de toda su existencia, una suma bastante para librarlo del hambre, o de ese triste trabajo de los viejos que de veras es una ignominia para cuantos no hemos imaginado aún el modo de evitarlo: ¡los viejos son sagrados! (EMS, 112; énfasis mío)

Como consecuencia de esta disparidad -más evidente y hostil en las ciudades en las que crece la miseria y la injusticia a ritmos acelerados- el capital busca una vía de escape y se lanza a la conquista de las tierras vírgenes del Oeste, a los desiertos del centro, a echar abajo las selvas vírgenes para que pase la maquinaria moderna del ferrocarril. En esa aventura de nueva conquista "todo tuvo que ser gigantesco, en acuerdo con los fines pasmosos de esta nueva epopeya, escrita por las locomotoras triunfantes en las entrañas de los cerros [...] escrita con las balas de los rifles sobre la testuz de los búfalos y el pecho de los indios". 21 Martí describe el nacimiento del monopolio, la expansión territorial sobre el Oeste, con la consecuente masacre ecológica del hombre 
blanco (cuyos efectos comienzan a ser visibles hoy) y el genocidio -al que volveremos en el capítulo siguiente- cometido con la población aborigen, considerados de raza y condición "inferior". Estas prácticas levantan más tensiones de las que había ya como consecuencia del incremento de las desigualdades entre la clase trabajadora y las élites económicas. De modo que para éstas últimas es claro que la economía industrial que quieren desarrollar necesita "sub-humanos: (gente) sin alma, despersonalizados [...] que puedan convertirse en miembros, o aún mejor, en pequeñas piezas de un complejo mecanismo", según señala Beatty, quien a la vez cita al sociólogo alemán Werner Sombar, quien escribe que el único problema es que "en América los sub-humanos eran ciudadanos libres". ${ }^{22}$ Por eso una de las más efectivas maniobras de los políticos y sus "politicianos" cuando querían lograr sus onerosas estrategias económicas, consistía en suprimir el voto de gran parte de la población y con ello conseguían tornarlos a su verdadera condición sub-humana.

Si embargo, un sistema de visibles desigualdades, incapaz de percibir -cegados por el poder y la riqueza- el creciente descontento de las masas a causa del crecimiento de las miserias e injusticias, debe estar listo a enfrentar constantes explosiones sociales que demandan una más justa participación de la riqueza que genera. De esta circunstancia va emergiendo la necesidad de manufacturar el consenso necesario entre las fuerzas productivas que garantice la continuidad del sistema sin que se produzcan cambios radicales. Para ello la élite va fomentando poco a poco su "cultura hegemónica", concepto extraído de los trabajos teóricos del filósofo italiano Antonio Gramsci. La hegemonía, de acuerdo al filósofo italiano "es el consenso espontáneo dado por las grandes masas de la población a la dirección general impuesta en la vida social por el 
grupo fundamental dominante". ${ }^{23}$ Tal consenso es el resultado del prestigio histórico alcanzado por el grupo que controla los medios de producción. Jack Beatty cita un ensayo del americanista Jackson Lears quien refiere la sutileza con que el poder hegemónico ejerce su dominio:

Gramsci se da cuenta de que cada lengua contiene los elementos de una concepción del mundo. El vocabulario disponible ayuda a establecer los marcos del discurso permisible, desalienta la clarificación de alternativas sociales, y hace difícil a los desposeídos localizar la fuente de su incomodidad y mucho menos remediarla. En los Estados Unidos, afirman los historiadores, el vocabulario del estado corporativo y su 'concepción del mundo' alcanza autoridad cultural solamente después de 1900. La 'gran ola de unificación' de 1895-1904 creó mega-corporaciones en industrias desde el hierro hasta el tabaco... ${ }^{24}$

De acuerdo a este historiador Estados Unidos alcanza su cultura hegemónica después de 1900 cuando se han consolidado las grandes corporaciones y se lanza una campaña intensa para convencer a Norteamérica que el gigantismo es bueno, aunque eso afecte al pequeño y mediano comerciante. Esas mismas estrategias fueron esgrimidas cuando Estados Unidos se preparaba a la aventura expansionista más allá de sus fronteras, después de dominar todo el oeste y haber arrancado a México, en una guerra sucia, la mitad de su territorio. Martí, que ve venir el proceso, lanza su no menos intensa campaña de información hacia América Latina con el objetivo de contribuir a frenar al gigante de las siete leguas que se viene encima de su querida "América mestiza" para lo cual hace pública sus preocupaciones, refiriéndose a esta gente que cree que el derecho de conquista es su destino manifiesto. Octavio Paz se refiere al fenómeno de la invasión de una civilización por otra y deja este comentario, que por su pertinencia trascribo completo: 
No es la primera vez que una civilización impone sus ideas e instituciones a los otros pueblos, pero sí es la primera que, en lugar de proponer un principio atemporal, se postula como ideal universal al tiempo y sus cambios. Para el musulmán o el cristiano la inferioridad del extraño consistía en no compartir su fe; para el griego, el chino o el tolteca, en ser un bárbaro, un chichimeca; desde el siglo XVIII el africano o el asiático es inferior por no ser moderno. Su extrañeza -su inferioridad- le viene de su "atraso". Sería inútil preguntarse: ¿Atraso con relación a qué y a quién? Occidente se ha identificado con el tiempo y no hay otra modernidad que la de Occidente. Apenas si quedan bárbaros, infieles, gentiles, inmundos; mejor dicho, los nuevos paganos y perros se encuentran por millones, pero se llaman (nos llamamos) subdesarrollados... ${ }^{25}$

En este pensamiento, el poeta mexicano sincroniza con el poeta cubano en cuanto al concepto de civilización que Martí desarrolla en "Nuestra América" y en "Distribución de diplomas en un colegio norteamericano". En la continuación de su reflexión, Octavio Paz describe la identificación que Occidente ha hecho entre los términos modernidad y civilización, perpetuando así la mentalidad colonizada al punto de que en los países hispanos muchos hablan de subdesarrollo cultural. ¿No es acaso esta falacia la que Martí ataca por todos los ángulos posibles con un preciso y dinámico torrente discursivo antihegemónico cuyo paradigma es "Nuestra América" porque ve claro lo peligroso y nefasto de tales fabricaciones para el futuro del continente. Como Martí, el Premio Nobel mexicano dice que "no hay una sola y única civilización" y "que en ninguna cultura el desarrollo es lineal: la historia ignora la línea recta". ${ }^{26}$ Luego dice que "Shakespeare no es más 'desarrollado' que Dante ni Cervantes es un 'subdesarrollado' frente a Hemingway". ${ }^{27}$ Finalmente, después de cuestionar el desarrollo lineal de la ciencia y del progreso, cuestiona igualmente el de la técnica, algo tan cacareado por la institución moderna, con lo cual vuelve a converger con lo que ya había dicho Martí en el XIX. Paz 
desmiente la universalidad de la aplicación de ésta en su propio país: "la irreflexiva adopción de la técnica norteamericana en México ha producido un sinnúmero de desdichas y monstruosidades éticas y estéticas. Con el pretexto de acabar con nuestro subdesarrollo... hemos sido testigos de una progresiva degradación de nuestro estilo de vida y de nuestra cultura". ${ }^{28}$

Retamar abunda en la mentalidad que caracteriza al colonizador cuyo objetivo es degradar a toda costa a ese otro de quien no conoce nada: ni su lengua, ni sus creencias, ni su ciencia, ni su técnica, ni su progreso, ni su civilidad.

Que los caribes hayan sido tal como los pintó Colón (y tras él una inacabable caterva de secuaces), es tan probable como que hubieran existido los hombres de un ojo y otros con hocico de perro, o los hombres con cola, o las amazonas, que también menciona en sus páginas, donde la mitología grecolatina, el bestiario medieval, marco Polo y la novela de caballería hacen lo suyo. Se trata de la característica versión degradada que ofrece el colonizador del hombre al que coloniza. ${ }^{29}$

De esa profunda convicción parte la estrategia discursiva de Martí a través de todos los medios que tenía a su alcance. Su labor deconstructiva, de los meta-relatos coloniales es una de las más intensas tareas que se impuso en toda su vida: su contradiscurso de la superioridad racial o cultural, su cuestionamiento del discurso racional, del cientificismo y del progresismo; de la ineficacia de los dogmas políticos y religiosos arrastrados por Occidente por más de veinte siglos e impuestos, consecuentemente, en sus colonias por la fuerza, son algunas de las direcciones en que cobra forma su escritura ética. Esta intensidad discursiva, encaminada a descabezar las seudo-teorías europeas, constituye la formación de su discurso anticolonial y su discurso americanista. La doble mirada martiana detectaba en estas pretensiones universalistas un erizado horizonte de 
violencia, injusticia y destrucción de la armonía y el equilibrio de la sociedad, principios esenciales de su cosmovisión ecuménica.

Los escritores metropolitanos de la vieja Europa contribuyen a alimentar la visión exclusivista y la mentalidad colonial alrededor del mundo. La batalla del imperialismo según advierte Edward Said- es sobre quien posee y usa la tierra. Y agrega que:

estos asuntos eran reflejados, debatidos y aún, por un tiempo, decididos en la narrativa. Como un crítico ha sugerido, las naciones son ellas mismas narraciones. El poder de narrar o impedir que otras narraciones se formen o emerjan es muy importante para la cultura y el imperialismo y constituye una de las conexiones claves entre ellas". ${ }^{30}$

También Foucault en $E l$ orden del discurso somete a un riguroso análisis estos conceptos y añade, a la idea de la colonización del espacio, la del control del conocimiento y de los discursos, práctica que puede detectarse en el ejercicio del poder ya desde los tiempos de Roma, sobre todo a partir de la imposición en todos sus territorios, de la religión cristiana. Pero en la época moderna el poder desarrolla otras estrategias, no detectables fácilmente por las masas, que operan a manera de control y censura de las ideas que pueden circular libremente en el espacio social. Según Foucault el poder hegemónico impone ciertas reglas en el uso de los discursos y cierta restricción a sus usuarios: "nadie entrará en el orden del discurso si no satisface ciertas exigencias o si no está, de entrada cualificado para hacerlo. Para ser más preciso: no todas las partes del discurso son igualmente accesibles e inteligibles; algunas están claramente protegidas". 31 En cambio otras, que no ofrecen peligro de desordenar o interrumpir el discurso oficial permanecen más accesibles o se ofrecen con mayor libertad. La protección del saber mantiene de esta manera una continuidad en la etapa del libre fluir de la información, 
como suele denominarse la modernidad. Lo único que cambian son los rituales: "el ritual define la calificación que deben poseer los individuos que hablan [...] define los gestos, los comportamientos, las circunstancias, y todo el conjunto de signos que deben acompañar al discurso". ${ }^{32}$ Fuera de esos rituales se impone una disciplina, una restricción, una línea sutil que marca el límite del uso discursivo. "Los discursos religiosos, judiciales, terapéuticos, y en cierta parte también políticos, so son apenas disociables de esa puesta en escena de un ritual que determina para los sujetos que hablan tanto las propiedades singulares como los papeles convencionales". ${ }^{33}$

A estas ideas podemos añadir la referida en The Darker Side of Renaissance por Walter Mignolo relacionada con la estrategia recomendada a la corona por su gramático Antonio de Nebrija de que la imposición de la lengua en los territorios conquistados era de vital importancia para la empresa de la conquista. De modo que esto corrobora las ideas de Said y de Foucault acerca del poder que las narrativas ejercen y como los imperios controlan los rituales discursivos para impedir que se formen narrativas alternas, así como la importancia que la lengua ha ejercido en las empresas de conquista y colonización. Martí, consciente de este dilema, va con toda la fuerza de su pluma a desbancar las ideas de la inferioridad de las culturas aborígenes, los hábitos colonizados del pensar latinoamericano y el sometimiento a valores importados por el colonizador, algo a lo que también Franz Fanon dedica varias páginas de su discurso anticolonial. La permanencia de este legado ideológico limitador lleva a Martí a desarrollar una narrativa de contra-conquista que le permita ir sustituyendo cada uno de los conceptos occidentales en los ámbitos de la literatura, la política, la religión, la cultura y la sociedad, remanentes del euro-centrismo y el universalista que Europa exportó y fijó en los espacios coloniales. 
Las literaturas europeas conforman uno de los campos de investigación más importantes en la obra teórica de Edward Said. En el proceso de investigación para la escritura de Culture and Imperialism se sorprendió al comprobar el reducido número de escritores que enfrentaron la noción de "razas inferiores" manejadas oficialmente para las respectivas empresas coloniales en Algeria e India. Para demostrar la complicidad de la intelectualidad europea en tales empresas, cita como ejemplos los casos de Dikens y Conrad, quienes a través de sus protagonistas, se hacen eco de la ideología racial y la mentalidad colonial. "Mucho de la retórica del Nuevo orden mundial promulgado por el gobierno norteamericano desde el fin de la Guerra fría $[. .$.$] con su ideología$ triunfalista...puede haber estado dibujado en Holroyd, personaje de Nostromo: somos número uno, estamos destinados a dirigir". ${ }^{34}$ Para Said, Conrad es uno de los precursores del punto de vista imperial sobre el "Tercer mundo". Esa mirada adopta la estrategia de desacreditar los movimientos de resistencia que para ellos están integrados siempre por gente corrupta e incapaz:

La novela de Conrad engloba la misma arrogancia paternalista del imperialismo que ridiculiza en personajes como Gould y Holroyd. Parece decir: 'Nosotros los occidentales decidiremos quien es buen nativo y quien no...Nosotros los creamos, les enseñamos a hablar y a pensar y cuando se rebelan confirman nuestro criterio de que son niños tontos...' Esto es en efecto lo que los norteamericanos han sentido sobre sus vecinos del sur: que su independencia debe ser deseada mientras sea la que nosotros aprobamos. Cualquier otra cosa es inaceptable y, peor, impensable. ${ }^{35}$

Esta es la razón por la cual Martí, en más de una ocasión, debe enfrentar las diatribas publicadas por la prensa norteamericana acerca de los cubanos, como lo hace igualmente para defender a los indios norteamericanos y al resto de los pueblos 
colonizados de América, Asia y África. Desde la primera mitad del siglo XIX Estados Unidos ha anhelado la posesión de la isla de Cuba. Lo proclama abiertamente en los medios de prensa. Veamos las similitudes entre lo que Said detecta en la novelística inglesa con la actitud de la prensa norteamericana. The Evening Post de Nueva York reproduce el 20 de marzo de 1889 un artículo aparecido en The Manufacturer de Filadelfia donde se acusa a los cubanos de afeminados, enemigos del trabajo, incapaces, corruptos y otras debilidades que los hacen inferiores al sajón del norte. Martí responde al diario neoyorquino con "Vindicación de Cuba", donde resalta los aportes de los cubanos a la nación norteamericana:

No es éste el momento de discutir el asunto de la anexión de Cuba. Es probable que ningún cubano que tenga en algo su decoro desee ver su país unido a otro donde los que guían la opinión comparten respecto a él las preocupaciones sólo excusables a la política fanfarrona o la desordenada ignorancia. Ningún cubano honrado se humillará hasta verse recibido como un apestado moral, por el mero valor de su tierra, en un pueblo que niega su capacidad, insulta su virtud y desprecia su carácter. (I, 236)

Con una meridiana claridad desmiente las opiniones peregrinas de este articulista ignorante que, embriagado del poder y la prosperidad económica de su nación ve a los demás inferiores. Se complace en explicar el aporte que los científicos, comerciantes, empresarios e ingenieros, maestros, abogados, médicos, artistas, periodistas, oradores y poetas cubanos han hecho, con "su inteligencia viva" a la nación más próspera del hemisferio. Reconoce que los cubanos admiran a los Estados Unidos "pero desconfían de los elementos funestos que, como gusanos en la sangre, han comenzado en esta República portentosa su obra de destrucción" Luego añade que sus compatriotas "no pueden creer honradamente que el individualismo excesivo, la adoración de la riqueza, y 
el júbilo prolongado de una victoria terrible, estén preparando a Estados Unidos para ser la nación típica de la libertad". Cuba no es ese "pueblo de vagabundos míseros o pigmeos inmorales que a The Manufacturer le place describir; ni el país de inútiles verbosos, incapaces de acción, enemigos del trabajo recio que...suelen pintar viajeros soberbios" Concluye su defensa con una idea que repetirá luego, referida a la lucha titánica del pueblo de Cuba por su libertad: "Merecemos en la hora de nuestro infortunio, el respeto de los que no nos ayudaron cuando quisimos sacudir el yugo colonial" (I, 236-37). Encara al yanqui sedicioso y critica a su gobierno que, más que socorrer a su vecino cuando ha estado en peligro, lo deja desangrar para obtener la deseada fruta madura a punto de caer, como hace finalmente cuando interviene en la guerra entre Cuba y España en 1898. Para un hombre de la estatura ética de Martí debe haber sido sumamente doloroso saber, por un lado, de las intenciones imperiales norteamericanas de apoderarse de Cuba y, por otro, como España, aún sabiéndose derrotada, prefería, en vez de otorgar la independencia a los cubanos, entregar la isla a Norteamérica. La constatación de estas dos posiciones de ilegitimidad y traición debe haber sido uno de los tragos más amargos para una vida entregada por entero en heroico sacrificio al logro de la libertad de su patria. En tal sentido advierte sobre los elementos que laceran la libertad y prosperidad de la patria de Lincoln: el excesivo individualismo, el materialismo y la soberbia. Martí tiene la certeza de que las políticas imperiales resultan catastróficas, tanto para quienes las ejercen como para quienes las sufren. En su concepción ética el ejercicio de la fuerza para oprimir a otros es una ignominia y una aberración, consecuencia del gigantismo, algo que no por azar ha entrado muy recientemente en el discurso político norteamericano. El mismo criterio está en Said cuando dice que la política imperial 
interrumpió el proceso de desarrollo político y cultural de las naciones donde intervino, pero finalmente fueron derrotados. Sin embargo, a pesar de las experiencias negativas del pasado "recientes actitudes en Washington y en la mayoría de los estrategas políticos e intelectuales de Occidente muestran muy poco avance con relación a la visión del novelista inglés". ${ }^{36}$ Para Conrad, señala Said, hay una futilidad en su filantropía imperial puesto que el modelo de democracia que intenta imponer es imperfecto e ineficaz en el criterio de muchos paises, o como señala Martí, porque después de la práctica muestra demasiadas inconsistencias. "Al menos Conrad tuvo el coraje de ver que tales esquemas no son nunca exitosos porque atrapan a los estrategas en más ilusiones de omnipotencia y auto-éxito (como en Vietnam), y porque por su propia naturaleza falsifican la evidencia". 37

\section{Su contra-discurso euro-céntrico y universalista}

La modernidad en América Latina es impuesta desde los centros de poder de Occidente. A esta modernidad - para él que conoce sus entrañases porque ha vivido dentro del monstruo- opone la originalidad americana del ser natural, del hombre autóctono, expuesto como criterio central de su ensayo "Nuestra América" El ser ético martiano no puede aceptar una modernidad que cometió un genocidio en América y robó una de las páginas más hermosas del libro de la historia. El mismo principio de universalidad que la modernidad europea proclama es, para Martí, muy sospechoso y contradictorio, como mismo lo es su concepto de civilización. Este concepto para él es inclusivo, no exclusivo; implica la aceptación de la diversidad, de la hibridez, de la 
heterogeneidad y no lo contrario; es un principio dialógico que no se funda, ni en la violencia, ni en el exterminio de los diferente. Es, en pocas palabras, un principio holístico, ecuménico donde se abra la hospitalidad y el clamor por la humanidad del otro hombre, como veremos más adelante. Martí no piensa como un europeo, ni como un norteamericano (el gran problema de Sarmiento y de tantos otros "pensadores canijos", como él los denomina), sino como un auténtico americano y sus fundamentales preceptos tienen como base esa visión del mundo que incorpora la otredad de su "América mestiza" y la justicia incondicional de la naturaleza que Europa ha civilizado, maniatado y encerrado en las urbes antiáticas. América conserva aún, a la llegada de los conquistadores su naturaleza virgen y sus habitantes han convivido con ella sin desencantarla, manteniendo su espíritu sagrado y, más importante, desarrollando una economía sostenible porque a la madre no se le deben arrancar todos los frutos, o todas las semillas para que pueda seguir procreando y continúe la cadena de la vida. Por eso uno de los principales ejes desde donde gira la escritura martiana es el del hombre natural, en armonía y equilibrio con la tierra que lo sostiene de la cual no es dueño, sino servidor y a quien agradece ceremonialmente lo que ella entrega en la feliz convivencia de todo lo que existe. En ese intercambio amoroso radica la libertad real.

Estos conceptos o esta visión martiana del hombre natural nada tienen que ver con la visión iluminista del buen salvaje. En Martí hay una comprensión muy clara de las contradicciones aparentes que otros encuentran irreconciliables. Quienes en América quieren favorecer formas e instituciones venidas de culturas ajenas a ella, no entienden que las formas eficaces y duraderas de gobernar salen de las circunstancias y el conocimiento que las culturas autóctonas tengan de sus tradiciones porque éstas son la 
verdadera historia de cada pueblo en específico. De ahí que en vez de historia, debería hablarse de tradiciones. La imitación servil de formas y modos extranjeros, (aunque vengan avalados por la auto-propaganda de superioridad de estas culturas que se han hecho tales por la explotación de pueblos menos afortunados) es una forma de bajar la cabeza para aceptar el yugo colonial. Para Martí la cuestión está en cómo ir educando a la América mestiza en el criterio de que las ideas, como las plantas, necesitan clima apropiado para que fructifiquen y en el hábito de amar lo propio. Desde la cátedra de su escritura, abierta en las páginas de los diarios del continente, desata una apasionada actividad educativa con el fin de echar por tierra todos los falsos ídolos del eurocentrismo y barrer del continente la mentalidad colonizada de parte de la intelectualidad latinoamericana y de sus élites políticas. "La universidad europea ha de ceder a la universidad americana. La historia de América, de los incas acá, ha de enseñarse al dedillo, aunque no se enseñe la de los arcontes de Grecia. Nuestra Grecia es preferible a la Grecia que no es nuestra" (18). Para deshacer el hábito colonizado de pensar, el hombre natural de América debe conocer su propia historia y entender que su grandeza autóctona y sus tradiciones son tan ricas como la de las metrópolis. Tiene perfecta conciencia de que esa batalla ha de ser una de las arduas y prolongadas para conseguir construir repúblicas libres, prósperas y sólidas. Los colonialismos y sus ideologías de dominio -como el ha comprobado en carne propia- calan tan hondo en el consciente colectivo de los pueblos que arrancarse esos hábitos de pensar es más difícil que vencerlos militarmente. Si el instrumento intelectual con que se piensa y escribe en las colonias es parte de la herencia colonial impuesta por el conquistador como estrategia de dominio, más difícil se torna dicha estrategia. Pero su fórmula es la justa y equilibrada: 
"Injértese en nuestras repúblicas el mundo; pero el tronco ha de ser el de nuestras repúblicas" (18).

Ahora bien, aunque Martí comprende que cuatro siglos de colonialismo no se pueden extirpar de un plumazo y que en las masas resulta más difícil ejercer esta profilaxis mental, le produce cierta indignación aceptar el colonialismo mental de la intelectualidad del continente. Este servilismo mental en intelectuales, que supone liberados de tales vicios y en posición ventajosa para contribuir a la eliminación en el marco social de dichas limitaciones, lo descorazona y angustia. Pero no por eso se sienta a esperar que por conjuro mágico la intelectualidad del continente se sacuda de encima la pereza mental y el amor desmedido por lo extranjero en desdén de lo propio. Sabe que con ellos también hay que batallar. Entre estos intelectuales que llamaba de "corta vista mental" los que juzgan la fruta por la cáscara y no van a las raíces de los problemas está Domingo Faustino Sarmiento, quien ataca a Martí por las críticas que éste viene haciendo del proceso democrático norteamericano a través de sus crónicas para la prensa del continente. $\mathrm{Al}$ argentino la sociedad norteamericana le parece perfecta, aunque no haya (como Martí) vivido en el país del Norte y estudiado con mirada ahondadora y sin ciegas pasiones sus instituciones y su proceso político. Disgustado entonces con lo que Martí escribe, lanza estas diatribas

Una cosa falta a Don José Martí para ser un publicista [...] Fáltale regenerarse, educarse [...] Quisiera que Martí nos diera menos Martí, menos español de raza y menos americano del sur, por un poco más del yankee, el nuevo tipo del hombre moderno. Hace gracia oír a un francés del Courier des Etats Unis reír de la beocia y de la incapacidad política de los yankees, cuyas instituciones Gladstone proclama como la obra suprema de la especie humana. Pero criticar con aires magisteriales aquello que ve allí un latinoamericano, un español, con los retacitos de 
juicio político que le han permitido los libros de otras naciones [...] es hacer gravísimo mal al lector, a quien lleva por un campo de perdición. ${ }^{38}$ (Énfasis mío)

Hay cierta contradicción entre la primera frase de este fragmento y otra que ha dicho en la que coloca al cubano entre los grandes escritores en lengua española. Pero lo que más asombra es ver como un intelectual tan reputado como Sarmiento se expresa con esta falta de delicadeza, de tacto y de elemental respeto de un escritor que era admirado, no sólo por él, sino por la intelectualidad de ambas orillas del Atlántico. Martí tiene que "regenerarse y educarse" para poder ser un buen periodista. Para esta fecha el estilo y la fuerza de su prosa han sido reconocidas por los editores norteamericanos y el propio Darío que quedado hechizado con esta forma de escribir nunca antes vista en lengua española. De manera que la única forma de entender estas palabras insultantes de Sarmiento es como resultado de la ceguera que caracterizan a la soberbia y la arrogancia. Martí es Para él un semi-indio, semi-español y como tal no tiene la capacidad intelectual suficiente para hacer un análisis equilibrado de lo que observa desde dentro del proceso en la sociedad norteamericana. Es obvio que entre las opiniones de Sarmiento y las de Martí media la distancia que hay entre Nueva York y Buenos Aires y entre un pensador universal y uno provinciano. Sarmiento parece santificar la peregrina opinión de que lo nuevo que se desarrolla en Estados Unidos es inmune a la crítica porque todo lo que nace allí es perfecto. No pude darse el lujo de escuchar que alguien critique lo que él ama con un amor platónico pues ni siquiera conoce lo que tanto admira y defiende. Por eso Martí no entiende, ni las diatribas de Sarmiento, ni la actitud que las respaldan pues nadie puede conocer un fenómeno tan complejo como es cualquier sociedad, mucho menos la 
norteamericana "por un saltito de placer como dice Martí. El poeta cubano después de haber residido en Estados Unidos por varios años, observando detenidamente todos sus procesos, ha entendido que no hay un solo Estados Unidos, pero eso no lo pude comprender el viajero de tránsito. Por eso las críticas martianas afectan -según Retamar- el "inacabable orgasmo histórico" de Sarmiento, empañan su objeto de adoración en la lejanía. La delicadeza y la persona ética que hay en Martí nunca responden a estas ofensas directamente. La referencia a la actitud de Sarmiento y a los que piensan como él están en sus ensayos y crónicas donde argumenta sobre la verdad que ha detectado su mirada órfica en el plano socio-político de la sociedad donde reside. Martí no devuelve al autor del Facundo sus improperios a pesar de que las opiniones del argentino eran diametralmente opuestas a su programa de liberación de los remanentes del colonialismo español en la mentalidad latinoamericana como la más efectiva preparación para la resistencia ideológica del nuevo colonialismo que veía venirse encima de sus queridas "patrias azules" por parte de ese mismo país que el idolatraba y en el que nunca pudo detectar sus intenciones imperiales.

¿Cómo habrá podido sentirse Martí ante estas opiniones, claras expresiones de una personalidad que favorecía las divisiones, las exclusiones, la fragmentación, el uso de la fuerza para explotar a unos en favor de otros, el genocidio de las razas autóctonas (que también alentó y practicó en su país para copiar a su modelo adorado), pero sobre todo el racismo que caracterizó su pensamiento y su acción? Como sabemos el pensamiento ético martiano era diametralmente opuesto a esta ideología colonial de Sarmiento. Pero, además el ejercicio del criterio era para Martí la esencia misma de la salud de la democracia. Sólo prospera realmente una sociedad en la cual sus intelectuales y artistas - 
y el pueblo en general- ejercen la crítica de todo aquello que puede disminuir, empañar o desequilibrar el desarrollo armónico de todas las esferas de la sociedad. Para Martí no hay ningún derecho a excluir, ni censurar, ni silenciar esas voces porque no convenga a quienes detentan el poder, puesto que el poder jamás, por sí mismo, podrá entender todas las dimensiones y ofrecer las adecuadas soluciones de los problemas que el complejo organismo de una sociedad produce, sin la ayuda que la critica sana proporciona. Si Sarmiento, por un mágico conjuro, pudiera pasear hoy por el seno de las democracias del continente, desde la bahía de Hudson, hasta Tierra del fuego, vería, con asombro, cuan pertinentes y oportunas eran las críticas martianas. Quienes alimentan la percepción -por ignorancia o por cobardía- de que silenciar las opiniones críticas de los ciudadanos produce algún bienestar, están condenados a repetir la historia, con los mismos errores, los mismos excesos y los mismos cataclismos. Sólo los pueblos -como nos recuerda Ortega y Gasset- que sostienen, avivan y estimulan la crítica de sus instituciones sociales y gubernamentales, como una práctica cotidiana, han alcanzado la real madurez y siguen siendo fieles al espíritu democrático original.

Contrario a Sarmiento, Martí aboga por la unión, la inclusión y el equilibrio de todas las fuerzas sociales y espirituales en el anhelo de construir una sociedad más justa. En "Nuestra América", con una sola frase pone fin a la prolongada disputa sostenida por intelectuales del continente, (entre los cuales Sarmiento es protagonista), sobre la civilización y la barbarie. Es una frase que condensa los dos polos del debate y los sintetiza y equilibra, llegando la raíz: "No hay contradicción entre la civilización y la barbarie, sino entre la falsa erudición y la naturaleza". (17) Para tener una idea más clara de la distancia que media entre la posición de ambos y en qué perspectiva se sitúan, 
examinemos algunos de sus pensamientos. Sarmiento parte de la premisa de que América es un continente salvaje, bárbaro y que sus habitantes pertenecen a una raza inferior, incapaz de producir progreso alguno. Por eso piensa que hay que exterminar a los indios en la Argentina, blanquear la sociedad, eliminar al gaucho. Roberto Fernández Retamar examina extensamente estas diferencias y en Calibán cita a Sarmiento, quien en Conflicto y armonia de las razas en América dice:

puede ser muy injusto exterminar salvajes, sofocar civilizaciones nacientes, conquistar pueblos que están en posesión de nuestro terreno privilegiado; pero gracias a esta injusticia, la América, en lugar de permanecer abandonada a los salvajes, incapaces de progreso, está ocupada hoy por la raza caucásica, la más perfecta, la más inteligente, la más bella y la más progresiva de las que pueblan la tierra; merced a estas injusticias, la Oceanía se llena de pueblos civilizados, el Asia empieza a moverse bajo el impulso europeo, el África ve renacer en sus costas los tiempos de Cartago y los días gloriosos del Egipto. Así pues la población del mundo está sujeta a revoluciones que reconocen leyes inmutables; las razas fuertes exterminan a las débiles, los pueblos civilizados suplantan en la posesión de la tierra a los salvajes. ${ }^{39}$

Para un lector contemporáneo, inmerso en el discurso de la hibridez y de los estudios culturales, de la antropología y la ética contemporáneas estas ideas pueden resultar repulsivas y hasta incomprensibles, sobre todo viniendo de la mente de uno de los intelectuales de mayor prestigio del siglo XIX americano, quien incluso llega a ocupar la presidencia de su país. Son, en principio, la negación absoluta del programa de "Nuestra América" que desarrolla Martí pensando en todas las razas, todos los pueblos, con todas sus expresiones culturales auténticas de sus tradiciones. Estas ideas de Sarmiento son portadoras de todas las limitaciones y contradicciones que el veneno racial seudo-científico europeo ha importado a Hispanoamérica y que tan hondo ha calado en la mentalidad del continente. En un mismo párrafo Sarmiento habla de justicia y de 
exterminio (genocidio sería hoy un término más apropiado), y dice que el colonialismo europeo resultó de gran beneficio a los pueblos que decapitó y subyugó por la fuerza. ¿Cómo puede haber justicia en el exterminio de otros pueblos por considerarlos inferiores, que a todas luces un crimen injustificable e irracional? ¿Cómo, en su sano juicio, puede alguien justificar la brutalidad y la barbarie que implica el subyugar a pueblos por la fuerza? África sigue siendo hoy el continente más saqueado, esclavizado y alienado del planeta como consecuencia del colonialismo, eso que precisamente Sarmiento aplaude y Asia comienza a florecer verdaderamente sólo cuando puedo sacudirse de encima los colonialismos que la han atado y frenado en su natural florecimiento. América Latina sigue padeciendo los mismos males y lacras que Martí criticaba en el siglo XIX y sus repúblicas han reproducido en ellas todas las falacias de los sistemas desarrollistas exportados desde los centros metropolitanos de Occidente. Defender el colonialismo resulta de una ceguera histórica tal, que mientras más se estudian y esclarecen los elementos discordes y las circunstancias espurias que los produjeron, más se acrecienta su incontestable negatividad. Pero estas ideas de Sarmiento y los proyectos que implementó para europeizar y blanquear su sociedad nos ayudan a poner en una mejor perspectiva cuan avanzado y revolucionario era el pensamiento martiano para su época, pues yendo al pasado indígena estaba abriendo el futuro, mientras Sarmiento destruyendo el pasado indígena lo estaba oscureciendo.

En su estudio de la sociedad norteamericana Martí detecta dos dimensiones en ella. Ve que hay la próspera de castas privilegiadas de la sociedad blanca que tanto deslumbra a sus hermanos de raza, pero ve que hay otra donde impera la disparidad, la injusticia y la miseria. Él es el primer escritor hispanoamericano en hacer esta distinción. 
Es de supina ignorancia y de ligereza infantil y punible hablar de los Estados Unidos [...] como de una nación total e igual, de libertad unánime y de conquistas definitivas; semejantes Estados Unidos son una ilusión o una superchería". ${ }^{40}$ Observador perspicaz de la realidad que vive detecta la presencia de dos mundos que se desconocen y escinden con una fuerza cada vez mayor en el plano económico, político, social y cultural aunque comparten el mismo espacio nacional. La clase privilegiada elige ignorar que hay grupos y clases en el país que no han sido incorporados al carro del progreso y la justicia social y distan mucho de "las ciudades del Este, arrellanadas, privilegiadas, encastadas, sensuales, injustas". 41 Esta realidad contradice los principios democráticos plasmados en sus documentos fundacionales. Detecta en el interior de la sociedad norteamericana "el carácter crudo, desigual y decadente de Estados Unidos, y la existencia, en ellos continua, de todas las violencias, discordias, inmoralidades y desórdenes de que se culpa a los pueblos hispanoamericanos" (XXVIII, 294). A diferencia del argentino, mira por encima de los sistemas porque no lo ciegan las candilejas. En consecuencia no aplaude lo que ve aplaudir a su vecino, si antes no ha comprobado su efectividad y bienestar. Esta batalla martiana contra los falsos ídolos, minando el discurso universalista europeo va conformando el ideario que cobrará cuerpo en "Nuestra América". El ensayo es, como se ve, el resultado de un largo proceso de análisis que abarca más de una década. Por eso hay en él una gran condensación de ideas paradigmáticas, escritas a manera de la síntesis poética similar a la empleada en el Prólogo al poema del Niágara. De ahí que el ensayo, frase por frase e idea por idea, sigue siendo la más auténtica y penetrante arqueología de las esencias su "América mestiza" y el programa de gobierno más real y efectivo para las repúblicas americanas de la misma manera es uno de sus documentos que con mayor 
fuerza desborda los presupuestos ideológicos de la modernidad burguesa. El siguiente pensamiento resume gran parte de lo que hemos venido diciendo:

Cree el soberbio que la tierra fue hecha para servirle de pedestal, porque tiene la pluma fácil o la palabra de colores, y acusa de incapaz e irremediable a su república nativa [...] La incapacidad no está en el país naciente, que pide formas que se le acomoden y grandeza útil, sino en los que quieren regir pueblos originales, de composición singular y violenta, con leyes heredades de cuatro siglos de práctica libre en Estados Unidos, de diecinueve siglos de monarquía en Francia. Con un decreto de Hamilton no se le para la pechada al potro del llanero. Con una frase de Sieyés no se desestanca la sangre cuajada de la sangre india [...] El gobierno ha de nacer del país. El espíritu del gobierno ha de ser del país. La forma del gobierno a de avenirse a la constitución propia del país. El gobierno no es más que el equilibrio de los elementos naturales del país. (VI, 16-17)

El racismo exportado por Occidente a América Latina fue el caldo de cultivo que propició las actitudes de sumisión y entreguismo de las élites políticas, económicas y culturales del continente y abrió las puertas al progresismo teleológico en la embajada del positivismo. De la misma manera fomentaron el calco de modelos que, por un lado, ignoraban, y más, desdeñaban los valores autóctonos de la "América mestiza" y, por otro, terminaron por importar un capitalismo subdesarrollado al convertirse las naciones del sur en destino del excedente del capital monopolista del mundo industrializado, al tiempo que proveedores de materia prima y mano de obra barata para sus industrias. Ya vimos antes -en palabras de Octavio Paz-cual fue el resultado que produjo en Hispanoamérica la importación de esos modelos de desarrollo que no se avenían a la índole de la realidad latinoamericana. De ahí que Martí advirtiera tan temprano que a América le había llegado la hora de declarar su segunda independencia. Quien quiera ver el resultado de las prácticas de esas seudo-teorías coloniales, sólo tiene que mirar el paisaje político y 
económico de América Latina hoy, más de un siglo después. La posición martiana, si extraña en aquella época; si expresión de un temperamento y un carácter que se movía a contracorriente, termina al cabo por imponerse frente a la moda positivista y está hoy más viva que nunca, mientras que aquella ideología, según opina Vitier, ha pasado a ser una pieza arqueológica de la cultura latinoamericana, aunque algunos insensatos intenten revivirla en el presente al amparo de ideologías trasnochadas. El cuestionamiento martiano de la civilización europea se da ya desde los años finales de la década del 70 . Hacia 1877, después de entrar en conflicto con los modos dictatoriales el despotismo ilustrado de Rufino Barrios, expresa en "Los códigos nuevos":

Interrumpida por la conquista la obra natural y majestuosa de la civilización americana, se creo con el advenimiento de los europeos un pueblo extraño, no español, porque la savia nueva rechaza el cuerpo viejo; no indígena, porque se ha sufrido la injerencia de una civilización devastadora, dos palabras, que siendo un antagonismo, constituyen un proceso; se creó un pueblo mestizo en la forma, que con la reconquista de su libertad, desenvuelve y restaura su alma propia. (VII, 98)

Dos conceptos claves se exponen en el fragmento anterior. El primero es que hay una civilización americana que fue interrumpida en su autóctono devenir y el segundo -que a su vez contiene dos ramificaciones- el de injerencia de la civilización europea de forma devastadora, y aclara - por las dudas- que las ideas de civilización y devastadora se contraponen. Este pensamiento tan temprano de Martí es el germen magnífico de su concepto capital sobre la civilización y la barbarie que cobrará forma definitiva en 1891 en "Nuestra América". Pero aquí queda claro ya que no es la civilización contra la barbarie, sino una civilización, la europea devastadora, contra otra civilización, la majestuosa americana. A la vez inserta el criterio de que si una civilización se impone por 
la fuerza y la violencia sobre otra, y la decapita, entonces, ese concepto de civilización, es cuestionable. Siete años después en su trabajo "Una distribución de diplomas en un colegio de los Estados Unidos, elabora más esas ideas. Lo interesante es que las trae a colación a propósito de la exposición que un estudiante hace de la presencia indecorosa de los ingleses en Egipto. Éste lee un estudio donde se defiende el derecho de los egipcios a gobernar su propia tierra. El fragmento deconstruye de manera contundente algunos de los conceptos capitales de las fabricaciones discursivas del euro-centrismo y el universalismo europeo. Martí señala que:

el pretexto de que unos ambiciosos que saben latín tienen derecho natural de robar su tierra a unos africanos que hablan árabe; el pretexto de que la civilización, que es el nombre vulgar con que corre el estado actual del hombre europeo, tiene derecho natural de apoderarse de la tierra ajena perteneciente a la barbarie, que es el nombre que los que desean la tierra dan al estado actual de todo hombre que no es de Europa o de la América europea. (VIII, 442)

Lo primero que hace es referirse al instrumento lingüístico como productor de discursos hegemónicos -idea bien avanzada para su época- y señala el latín para ese conglomerado de "civilización" que no ha sido otra que la lengua del Imperio, el que impuso una tradición política, económica, cultural, jurídica y religiosa a todo el Occidente, con lo cual sugiere que de allá a acá muy poco ha cambiado, confirmando el vínculo que ve entre el Imperio Romano y los colonialismos europeos y la Roma de América como indicamos antes. De manera que estamos aquí frente a un concepto histórico interesante. En su contra-discurso desbanca la falacia del derecho natural, ,.......... alimentado por la doctrina cristiana que a punta de lanza impuso en el Nuevo Mundo su credo nefando. Luego, como pocos antes de él, considera que es vulgar ese auto- 
calificativo que Europa se atribuye, pues cómo ha de ser civil apropiarse del derecho ajeno por medios violentos. En la sutileza de la frase subyace la idea de que la invasión, conquista y colonización de territorios ajenos por medios violentos puede ser un ejercicio de fuerza bruta -que es en sí una aberración- pero nada tiene de civilizado. Por eso concluye que le parece vulgar ese auto-calificativo del hombre europeo, por no decir bárbaro y contrario al dogma que ellos mismos practican. Critica así la racionalidad con que éstos avanzan sus ambiciones sobre naciones de lengua y cultura diferentes a las suyas. Cuando usa la frase "el estado actual", aplicada tanto al hombre europeo, como al no europeo, en vez de usar el de civilización, está insertando el factor histórico como elemento primordial en la valoración de los niveles de desarrollo de cada cual sin que ello implique la superioridad del uno sobre el otro.

La historia para Martí no es la saga de los acontecimientos de los vencedores, ni un libro despojado de alma y de naturaleza. No comienza ni con la Ilustración, ni con el Renacimiento, ni con las Cruzadas, ni siquiera con el Imperio latino. La historia $\multimap$ el devenir de las sociedades, fenómeno que no es privativo de ninguna civilización- es un extenso arco que va desde la más remota antigüedad moldeando el espíritu de la humanidad y cubre lenta y dolorosamente todos los estadios del hombre. La modernidad, como nos recuerda Octavio Paz- ha pretendido hacer ver que en ella todo pasa más velozmente y suceden más cosas y que la historia comienza y termina en ella. Por eso se complace en aniquilar una y otra vez el pasado con lo cual asume una actitud suicida pues el presente es una fugacidad constante hacia el pasado, el instante de cero duración. "La modernidad se opone incansablemente, no sólo al pasado (lo antiguo, lo tradicional), sino también a sí misma". ${ }^{42}$ La mirada martiana sigue ese arco de continuidad que abarca 
más de cuatro milenios sin dejar que el pasado sea expulsado de su presente porque ha aprendido que esa es la única certeza. Por eso para él tal hermenéutica es simplista, reduccioncita y apocalíptica.

\section{Minando el historicismo lineal y el progresismo teleológico.}

Hay cierta ontología arcaica en el pensamiento del héroe cubano que se resiste con toda verticalidad a esa línea sin fin de la modernidad que sitúa la justicia y la libertad del hombre en un paraíso que siempre está más allá de la línea visible del horizonte humano. Para empezar Martí sabe que el paraíso es un símbolo que el cristianismo racionalizó y materializó, degradándolo de su idea original en las escrituras y creencias más antiguas. El paraíso está en ese país que llevamos dentro de que nos ha hablado antes y que constituye el verdadero viaje de resurrección, revelación e iluminación que el hombre mismo, con las herramientas de su propio ser, sin ningún dogma o promesa de salvación debe recorrer, hacia su cielo interior. Su oposición al historicismo progresista occidental se fundamenta en su estudio íntegro de los factores que conforman el proceso histórico-cultural de esa civilización. Él sabe qué factores y elementos han venido a conformar el supuesto universalismo que se atribuye. En su contra-discurso alienta, no sólo un universalismo de índole muy diferente -más dialéctico, más inclusivo, más armónico, más ecuménico- sino que, además, se resiste a aceptar que el destino de los países de América y, por extensión, de la humanidad toda, dimanen de una civilización que ha producido la barbarie del colonialismo. Piensa no sólo con Europa y Norteamérica, y en contra de ellas, sino piensa también como un hombre natural, 
superior, en su concepto, al hombre occidental. En tal sentido piensa desde la periferia, al margen de los meta-discursos de su época Hace su propia síntesis con la cual ha tornado la rígida linealidad exclusivista moderna en el círculo aleatorio y fraterno de la ecumene. Es decir ha creado -como ya referimos- el primer discurso híbrido del continente. Ahora bien Martí no es ciego ni al progreso material, ni a las libertades que garantiza el desarrollo de la individualidad y el ejercicio del albedrío de las nuevas bautizadas democracias. Pero desconfía de ciertas doctrinas que se han santificado en el altar de la ciencia en la que encuentra muchos agujeros por donde penetran la injusticia, la desigualdad y las miserias humanas.

La doctrina del progreso, la confianza en las posibilidades beneficiosas de la ciencia y la tecnología, la preocupación por el tiempo ( un tiempo mensurable, un tiempo que puede ser comprado y vendido y que por tanto tiene, como cualquier otra mercancía, un valor equivalente en dinero), el culto de la razón, y la idea de la libertad definida dentro del marco de un humanismo abstracto, pero además, la orientación hacia el pragmatismo y el culto a la acción y al éxito -todas han sido asociadas en grados diferentes con la batalla por lo moderno y fueron mantenidas vivas y promovidas como valores esenciales en la civilización triunfante establecida por la clase media. ${ }^{43}$

Martí se opone a la historia que hace una minoría en detrimento de una mayoría, simplemente porque eso es contrario a la índole de la democracia y como tal se convierte en una falacia. El derecho a decidir el destino de la humanidad le corresponde a toda la humanidad y no a una parte de ella. Al confiscar la historia para su uso exclusivo, el estado moderno crea su propio paraíso, es decir, su propia utopía, su propia cárcel. En cuanto al historicismo teleológico hegeliano hay que decir que Martí tiene una visión diferente en el sentido de que para él esa linealidad histórica causalista, con metas 
preestablecidas en el futuro, distorsiona y oblitera nociones que están al margen de esa estrecha concepción. En este sentido Martí aboga por un cambio de dirección que permita a la sociedad alcanzar un nivel de armonía y desarrollo en el conocimiento del ser similar al que poseían las sociedades primitivas en que el ciclo de la vida se ajustaba al ciclo de la naturaleza, en que la vida espiritual y la material conformaban una unidad sagrada.

Otra de las construcciones discursivas que Martí desarticula en su escritura ética es el progreso de Occidente. Primero que todo, su criterio de progreso no es teleológico y segundo incluye valores que rebasan la estrechez conceptual del progreso sólo en la esfera material. Después de seis años de vivir en Estados Unidos y de analizar los elementos sociales y los factores políticos en el país más avanzado del mundo moderno, comprende que ni la libertad política, ni el progreso social han cuajado en forma y esencia como se propaga y difunde. Para él la falta de visión en la planificación y ejecución de los proyectos modernizadores de las ciudades ha producido resultados contraproducentes. Cuando ve el modo impar en que se distribuye la riqueza, la política de una producción incontrolada que excede las necesidades reales de consumo, el control de las tierras en manos de compañías que no las trabajan, ni las entregan a los colonos, la sobre-valorización de los terrenos en las ciudades, y las rentas onerosas que los obreros deben pagar por "estrechas e inmundas habitaciones", comprende que ese progreso es una falacia. Cuando ve que la tierra y la industria en manos de corporaciones que se enriquecen a costa de la explotación del obrero que ha sido despojado de derechos, cuyas condiciones de labor son deplorables, entiende que ese progreso, ni es real, ni es beneficioso, ni es justo, ni es equitativo, ni es progreso. Por otro lado ataca esa concepción del tiempo que la modernidad inaugura como el valor supremo de la vida, 
como el oro de la modernidad porque, en esencia, esa visión del tiempo es portadora, de una parte, de desequilibrio y deshumanización para el hombre, y de otra, de un proceso de degradación de la naturaleza. De modo que decide, con su escritura volver al ritmo de la naturaleza lo que la modernidad ha puesto en el ritmo acelerado de la "urbe antiática", de la civitas. En "El terremoto de Charleston" hay una frase un tanto misteriosa sobre el tiempo en la que establece la dicotomía tiempo histórico / tiempo natural. Dice: "nadie sabía la hora: todos los relojes se habían parado, en el primer estremecimiento" (249). Es decir, cuando la naturalezá nivela todo lo que el progreso ha desnivelado, cuando castas y clases, esclavitud y explotación desaparecen en la tragedia, el tiempo histórico cesa y se abre el tiempo del ser que no necesita relojes mecánicos. Describe las escenas en que las locomotoras -signos dilectos del progreso de la época- son desencajadas de sus raíles y lanzadas a los pantanos como juguetes que una "poderosa maga" manipulara a su antojo. La más sofisticada mecánica del progreso resulta anulada por la fuerza de la naturaleza en un abrir y cerrar de ojos. $\mathrm{Y}$ es el ojo del cronista el que quiere que miremos las lecciones de superioridad de la naturaleza frente a la técnica. En el sub-texto deja entrever la idea de que la civilización que ha querido civilizar a la naturaleza, llevándola con mucha frecuencia por los torcidos caminos de su razón fragmentada, termina por sufrir los embates de ésta cuando quiere sacudirse las torceduras y mecánicas que esa mano "civilizada" ha inscrito en su sagrado pergamino. Por otro lado, a causa de la sacudida de la naturaleza, "los negros y sus antiguos señores han dormido bajo la misma lona, y comido del mismo pan de lástima, frente a las ruinas de sus casas"44 porque ella nunca hubiera creado esas diferencias. Las sutilezas de este trabajo, o su discurso del deseo pueden entenderse mejor si se tiene en cuenta su cosmovisión y el papel que la naturaleza 
juega en ella. Para el cronista la naturaleza es "templo", en oposición a la "profanación del comercio de la ciudad". Es madre que extiende sus brazos y abraza a todos por igual, es hogar fecundo y armonioso, de carácter moral, "vuelve al hombre a la razón y la fe, y es la juventud perpetua". Y también "Inspira, cura consuela, fortalece y prepara para la virtud al hombre". ${ }^{45}$ Según él todos hemos sido besados por esa "maga". Por último también nos dice que la naturaleza desdeña la riqueza y la soberbia por las cuales se sacrifica, pensamiento, que a su vez, tiene numerosas implicaciones, sobre todo, en el presente debate acerca de la crisis ecológica de la ecumene. Todo ello nos ayuda a poner en contexto sus impresiones en "El terremoto de Charleston" con mayor objetividad.

Ya antes he referido al analizar su contra-discurso de la modernidad estética algunos elementos relacionados con su visión de la naturaleza. No sería ocioso aquí apuntar que para Martí la naturaleza constituye el eje que sostiene su cosmovisión del mundo. Pero la naturaleza en él es más que una naturaleza, es una sobrenaturalaza. Para decirlo quizás de un modo más claro, la naturaleza de Martí en cualquiera de sus contextos es la naturaleza del hombre dentro de la naturaleza física de la madre tierra, es decir es una naturaleza dentro de la naturaleza que engendra esa sobrenaturalaza que refiero. He dicho igualmente $-\mathrm{y}$ vale la pena repetirlo ahora- que la escritura martiana está saturada de naturaleza, siendo prácticamente imposible encontrar una página suya donde no haya una referencia a la naturaleza o donde no intente naturalizar todo lo que haya sido, en una forma $\mathrm{u}$ otra desnaturalizado. Eso es visible en sus crónicas norteamericanas en las que cuando habla incluso de los adelantos mecánicos o de las grandes obras de ingeniería que la modernidad despliega en todos los escenarios publicitarios, cada elemento mecánico encuentra su contrapartida natural. Es como si a 
través de su escritura volviera a poner la naturaleza de donde ha sido desplazada. Un cable de hierro es una rama, un bote semeja una tortuga, la muchedumbre es ola, los trabajadores se despedazan como alas de mariposa, etc. Es decir, reordena el caos moderno a través de la naturaleza:

José Martí va a recurrir a la naturaleza para darle un vuelco a todo el sistema de representación. Si para los románticos, costumbristas, relistas, positivistas o hasta los periodistas liberales que eran sus contemporáneos, la razón y la inteligencia eran los instrumentos para domesticar a la barbarie natural, si la industria se imponía sobre lo escondido homogeneizando y ordenando, para Martí la Naturaleza haría volver a su cauce una realidad que él -por el contrario- sentía desordenada, heterogénea, en crisis. Sus mejores crónicas [...] tienen en la Naturaleza el patrón que permite derribar los moldes impuestos por la civilización y hallar por fin alguna armonía... ${ }^{46}$

Para la modernidad la naturaleza es un taller donde ensaya sus elucubraciones mecánicas y científicas. Turgueniev lo encarna bien en Basarov, personaje de Padres e hijos, novela que pinta la Rusia de la segunda mitad del XIX. El personaje representa la nueva fuerza intelectual, que afirma la nueva ciencia y los valores no sentimentales: es vulgar, despiadado, impío y brusco. Se burla de todo y "cuando el padre interpreta a Schubert... se ríe de él estrepitosamente. Basarov propone las ideas de la ciencia materialista alemana: la naturaleza para él no es un templo, es un taller [...] su energía intelectual anárquica, a menudo, sugiere caos". ${ }^{47}$ Para el poeta cubano la naturaleza es la fuente, el seno, el amor, la belleza, la armonía, la divinidad y el misterio. Es templo y no taller. No puede haber dos posiciones más contrarias que la del discurso progresista teleológico moderno y la escritura ética martiana. Tanto en su poesía, como en su prosa la Naturaleza -que el escribe con mayúscula- es el principio y el fin del hombre, su alfa y 
su omega. Por eso afirmamos que Martí es la más absoluta negación de ese Self-made man, individualista, pragmático, arrogante, soberbio y represor de los sentimientos, el huérfano perpetuo de la modernidad burguesa.

\section{La escritura martiana y pensamiento científico moderno.}

La afirmación de algunos críticos en cuanto a la filiación ideológica de Martí con relación al positivismo o el krausismo es una posición, desde mi punto de vista, reduccionista. Para él el positivismo era una "doctrina timorata" y "Krause no es todo verdad...sólo lenguaje simplificador" (XXI, 98), con lo cual confirma lo que hemos afirmado antes en relación con su independencia como pensador. La filiación de un escritor a una escuela o sistema filosófico implica una pensamiento sustentado en los presupuestos de tal filosofia. La visión del mundo martiana, ni es positivista, ni es krausista, ni es evolucionista, ni idealista, ni existencialista aunque haya bebido de todas esas fuentes, como bebió también del trascendentalismo norteamericano, y del materialismo alemán, y del barroco español y de la mística oriental y de la filosofía clásica antigua y moderna y de las mitologías americanas, y del platonismo, del cristianismo, del estoicismo, y del hinduismo. Es cierto que estudió con fervor muchas de las corrientes de pensamiento de su época y de épocas anteriores. Pero intentar reducir su obra a una escuela, sistema o corriente de pensamiento (como han pretendido hacer algunos estudiosos de su obra, tanto en Cuba como fuera de ella) es, no sólo pretencioso, sino inexacto. Es, a todas luces, una expresión del desconocimiento de la totalidad de su escritura y de los conceptos cardinales que conforman su cosmovisión. Es del criterio de 
que el modo más efectivo de librarse de los sistemas filosóficos es "nutrirse de todos y ver cómo en todos palpita un mismo espíritu, sujeto a semejantes accidentes, cualesquiera que sean las formas de que la imaginación humana...haya revestido esa fe en lo inmenso y esa ansia de salir de sí...que generan todas las escuelas filosóficas" (XV, 361). Si hay algo que realmente distingue a Martí como pensador es su asistematicidad, su resistencia a todo intento de encarcelamiento del espíritu humano. En su escritura deja numerosos testimonios de tal actitud. Disiente -para fortuna nuestra- de todos los absolutismos y de todas las totalizaciones discursivas. Esa es la verdadera naturaleza de su escritura: su marginalidad discursiva o -si se prefiere- su irreductibilidad epistemológica. "Adoro la sencillez, pero no la que proviene de limitar mis ideas a este o aquel círculo o escuela, sino la de decir lo que veo, siento o medito...En el esfuerzo por obtener este estilo, que unos dicen he logrado, me aparté sin duda mucho de lo corriente" (XXII, 101-02). Su escritura se hace, a veces, permeable a la filosofía, a la ciencia, a la lingüística, a la psicología, a la sociología, a la arqueología. Todos esos discursos le son familiares y los puede recrear, pero nunca sistematiza ninguno de ellos porque su pensar está en constante giro y su órbita desborda la gestualidad discursiva de estas disciplinas, pues no tolera los lenguajes disciplinarios, ni las narrativas confinadas que pueden frenar su capacidad aleatoria-analógica o su compromiso con la verdad. Los griegos llamaban Frónesis al saber ético, práctico por encima del saber teórico (Sofía). Y ya sabemos que el saber martiano es ético. De ahí que su escritura tienda más a la arqueología que a la filosofía; por eso está llena de esencias, saturada de naturaleza, en vez de axiomas y doctrinas, aunque éstas no falten cuando es necesario. Cuando un pensador se sabe auténtico, original, creador de un estilo único, no necesita afiliarse a ninguna doctrina o sistema de 
pensamiento, sino que toma de todas las fuentes del saber que le son accesibles y luego las funde en su propia fragua y lo que obtiene es su propio, inconfundible y original pensamiento. Eso es lo que hace Martí y de esa certidumbre dimana la pertinencia y la permanencia de su decir.

Por supuesto, este fenómeno siempre entraña desconcierto para la crítica, sobre todo la ortodoxa. ¿Cómo valorar con acierto una escritura que resiste el canon? ¿Dónde poner esa prosa que se disgrega hacia todos los confines del saber humano? ¿Cómo aceptar expresiones vanguardistas en una poesía de verso clásico? ¿Cómo lidiar con las formaciones de un logos que a trozos de vuelve irracional, o mejor, contraria a la razón cartesiana, o desbordándola? Ese es, y Martí lo sabía, su mejor aporte al pensamiento occidental y en ello radica la actualidad y vitalidad de su escritura. Hablando de Emerson nos dice que el genio no acepta reglas, sino que las crea y en su cuaderno 6 que "la ley es para los que carecen de sabiduría (XXI, 186). Ahora por el hecho de que profesara una honda admiración por el pensador norteamericano debemos decir que era sólo trascendentalista; porque leyó a Kant y Schopenhauer, decir que era idealista, porque leyó a Hegel y Marx que era materialista o marxista; porque leyó a Compte, Darwin, Spencer que era positivista o evolucionista o determinista o algo por el estilo. O ¿qué decir con relación a Nietzsche, a quien no leyó, pero con quien coincide en varias ideas importantes? A todas estas corrientes de pensamiento se asomó, de todas bebió, de ellas habló, o escribió, pero a ninguna entregó por entero sus armas del juicio porque era demasiado independiente en el pensar y en el actuar, porque era un espíritu demasiado. revolucionario y ecléctico como para aceptar las verdades mediáticas y las estructuras racionales y rígidas del pensamiento moderno. De ahí que se pueda afirmar sin pecar de 
chovinismo que en él se da uno de los pensadores más originales y libres de la época moderna. Este pensamiento, que es antecedente del Prólogo al poema del Niágara lo evidencia: "Yo nací de mí mismo, y de mí mismo brotó a mis ojos, que lo calentaban como soles, el árbol del mundo" (XXI, 167). Es decir, él se auto-engendró, se parió a sí mismo y por tanto su vínculo no es con los sistemas que caducan, sino con las esencias, con la maravilla de lo intocado, con lo inefable de la poesía que puede traspasar el velo y ver el otro lado del misterio, las junturas por donde se entreteje la flor del universo en el silencio magnífico de la fábrica cósmica. En Ese sol del mundo moral Vitier afirma:

el rechazo del principio de autoridad, que en Caballero, Varela y Luz tendía [...] a separar lo filosófico de lo teológico, a modernizar el pensamiento y a fomentar el espíritu crítico-creador, en Martí se profundiza hasta llegar a las raíces mismas de la libertad y autoctonía espiritual del hombre. Luz había interpretado la "duda metódica" cartesiana en el sentido de que "cada hombre levante de nuevo el edificio de su ciencia". Pero Martí no habla sólo ni principalmente de la ciencia filosófica en cuanto explicación del mundo, sino de una concepción original y militante de la vida humana; por eso dice: "Toca a cada hombre reconstruir la vida humana: a poco que mire en sí la reconstruye. (83)

Es, de todo punto obvio, que la cosmovisión martiana resulta de una hibridez profunda y de un anti-academicismo absoluto. Ni el positivismo, ni el krausismo, ni el pragmatismo, ni el utilitarismo, ni el progresismo, ni el cristianismo, ni ningún ismo fueron las corrientes de pensamiento que Martí adoptó en la elaboración de su escritura, porque todas ellas le resultaban incompletas para pintar el cuadro humano que estaba en su visión órfica. Todas eran portadoras de una visión fragmentada de la realidad. En resumen lo que hay en su escritura es una fascinante aleatoriedad gracias a su disentir con el causalismo, el dualismo y con el telos de la racionalidad. Debido a su oposición a las 
corrientes ideológicas europeas coloca su escritura ética más allá del cogito racional cartesiano, en el espacio liminal de su arcaico profundo. Su verdadero telos será la poesía.

Ha habido, asimismo, críticos que han pretendido asociarlo con el positivismo y sus tendencias afines. A propósito de Darwin y su Evolución de las especies comenta que "es ésa la ley, ya famosa, de la selección natural, que inspira a los teorizantes cegables y noveles, que tienen los ojos ligeros y sólo ven la faz de las cosas, y no lo hondo" (XV, 72). Luego al comparar los seres vivos dice que hay que dar "por de contado que existe semejanza de inteligencia entre el hombre y el resto de los animales" (373), algo tan contrario al pensamiento de su época y tradición en que la ciencia, erigida en juez supremo del saber humano, había colocado al hombre en un pedestal privilegiado con respecto a los demás seres vivos con lo cual firmaba el certificado de defunción de muchas especies que hoy sólo aparecen, como memoria, en los libros. Esta selección natural que -según Martí- complacía tanto a los pensadores alemanes, quienes las daban por segura, está en la raíz de la dilapidación de los recursos naturales del planeta al extremo de alcanzar ese punto de no retorno que hoy forma parte del debate político y científico internacional. Pero nuestro poeta se alarma."de pensar que cosas tan bellas como los afectos, y tan soberbias como los pensamientos, nazcan, a modo de flor de la carne, o evaporación del hueso, del cuerpo acabable. El espíritu se aíra y se aterra de imaginar que serán vanos sus bárbaros dolores" (373). Como se ve el pensamiento es soberbio y el espíritu imaginativo, idea recurrente en su escritura. Más adelante se pregunta si ¿es que es loca la ciencia del alma, que cierra los ojos a las leyes del cuerpo que la mueve" o es que lo es "la ciencia de los cuerpos que niega las leyes del alma 
radiante?" (373) para luego contestarse él mismo con la idea suya de que la vida es doble y se unifica en el uno-diverso de que habla en "Emerson". Hacia el final de este artículo inserta otros elementos disonantes y claramente dirigidos a desestabilizar y minar lo que ve de falso en el discurso científico y habla de "esa arrogancia presuntuosa" y "ese culpable fantaseo de los científicos apasionados que les mueven a callar los hechos de la Naturaleza que contradicen sus doctrinas, y exagerar las que les favorecen" (375).

Otra de las ideas que en mi criterio desacreditan la filiación positivista martiana aparece en su artículo Darwin y el Talmud, publicado en La América de Nueva York en 1884. Allí Martí comienza diciendo que un perspicaz lector de textos antiguos -que a todas luces es él mismo -ha constatado que los hebreos eran fervientes observadores de la naturaleza y que en las observaciones de éstos se nota la "presencia de ideas semejantes a las que ahora pasan por novísimas y nacidas de Darwin". Dicho "lector" también observa que en la época antigua los hombres no creían que los animales fueron seres sin inteligencia -como se creyó después-, sino que el nivel de inteligencia era diferente. El lector describe las observaciones precisas que aparecen en el libro antiguo sobre la conducta de los animales, ofreciendo deducciones de las mismas. Y concluye:

Pasa el positivismo como cosa nueva, sin ser más que la repetición de una época filosófica conocida en la historia de todos los pueblos; porque esa que hemos trascrito del Talmud no es más que la timorata doctrina positivista, que con el sano deseo de alejar a los hombres de construcciones mentales ociosas, está haciendo el daño de detener a la humanidad en medio de su camino. (XV, 403)

Tres conclusiones importantes se derivan de este análisis: la primera; que no hay tal novedad como la que se le atribuye a Darwin y a todo lo que se añade luego de 
Spencer, Heine y Compte - a quienes descalifica también-; la segunda, que ha existido en la historia de todos los pueblos desde la antigüedad y por lo tanto no es una invención de la "inteligencia" europea y la tercera que no es una doctrina infalible y él no le concede esa primacía y prestigio con que viene avalada al llamarla "timorata". Hacia el final plantea que es necesario "poner tierra primero antes de adelantar un paso en ciencia; pero no se puede hacer calzada al cielo. El viaje humano consiste en llegar al país que llevamos descrito en nuestro interior, y que una voz constante nos promete" (XV, 403). Es decir, Martí advierte que la ciencia no puede avanzar dando palos de ciego, sin analizar antes qué consecuencias se derivarán de sus elucubraciones y de los inventos que saldrán de éstas. Insertar en la realidad preceptos o doctrinas o la inútil materialización de éstos desvía al hombre de su natural cauce de acción y oblitera sus sentidos. Y esa saturación de los sentidos con una incontenible avalancha discursiva, sumado al crecimiento desproporcionado del mundo material surgido del discurso científico, son los ingredientes constitutivos de la creciente neurosis que él observa en la sociedad de su tiempo que ha ido en aumento por los últimos ciento cincuenta años ${ }^{48}$. Pero lo realmente singular de este fragmento son dos afirmaciones que bastan cada una para un ensayo por separado. Primero, que "no se puede hacer calzada al cielo". ¿No es acaso esto lo que precisamente ha venido haciendo la civilización occidental desde Roma al imponer un principio de autoridad y una entidad de poder omnímodo sobre las masas impidiendo el ejercicio del albedrío humano y la plena constitución de la vida del hombre? No creo que haya mejor frase para sintetizar ese camino recto trazado por el racionalismo occidental que esa de trazar calzada al cielo. En ella hay una legítima y firme crítica al discurso científico -aliado incondicional del poder - de la modernidad burguesa. Solamente esta 
afirmación bastaría para convencernos de que Martí desaprueba la forma inútil y ciega en que la ciencia moderna ha ido avanzando desligada de las necesidades esenciales del ser humano o "deteniendo a la humanidad en medio de su camino". Si consideramos los estudios de los últimos cincuenta años sobre la doctrina del progreso y cómo el estado moderno ha sido un creador de necesidades inútiles para el hombre, comprenderemos la profundidad de esas palabras. Segundo, "El viaje humano consiste en llegar al país que llevamos descrito en nuestro interior”. ¿Qué significa en esencia esta sentencia? Para empezar, que el viaje de la modernidad hacia el futuro progresista racional, hacia el exceso, la desmesura y el gigantismo no es el camino del hombre, que una vez que ha entendido la futilidad, la oquedad y la náusea nihilista de tal viaje, se da cuenta que va en la dirección equivocada. ¿No es esta la mejor explicación a la frase que comienza ese texto tan comentado por nosotros del Prólogo al poema del Niágara cuando dice: "Pasajero, detente" que contiene precisamente su doctrina de la "reconquista del ser", de que desarrollo con la teoría de la ética contemporánea. Martí pide al pasajero que se detenga porque ese deambular incesante con el aturdimiento del ruido mecánico y la embriaguez de la riqueza material no es el viaje. El verdadero viaje es hacia el interior del ser humano. Allí está su cielo y su oro y descubrirlo es la verdadera revelación, la verdadera epifanía del ser, su real trascendencia. Estas ideas tienen su raíz en la mitología antigua que los teólogos -según Foucault y también Campbell- por su incapacidad para la filología, o el arte de leer bien los símbolos, interpretaron mal o falsearon. Entre esas falsificaciones están precisamente las ideas del cielo y el infierno, como también la del oro que buscaban los alquímicos, todo lo cual estaba dentro del ser, pero ellos lo materializaron y racionalizaron y al hacerlo degradaron esos mitos. Con esto quiebra una 
vez más el historicismo teleológico y el progresismo lineal, a la vez que desacredita el programa científico de la modernidad burguesa. Si unimos este viaje hacia el país de nuestro interior, al que emprende en hacia el mundo aborigen de su América mestiza en su empresa de contra-conquista, pregunto: ¿Habrá todavía alguna duda de que Martí estaba muy en la periferia de la modernidad y que su mundo ético estaba en una lejanía casi invisible de detectar para ese poder hegemónico autodestructivo del mundo moderno burgués.

Concluyo el apartado con una cita de que nos ilustra mejor sus criterios sobre las reputadas teorías de su época. "Unos son segundones, y meras criaturas, de empacho de libros, y si se les quita de acá el Spencer y de allá el Robot, y por aquí el Gibbons y por allí el Tucídides, se quedan como el maniquí, sin piernas ni brazos" (IV, 380-81). Estas afirmaciones corroboran una vez más lo que he afirmado sobre la independencia filosófica martiana y la soberanía de su pensamiento. Martí ve ciencia y leyes en el espíritu y fantasía e imaginación en la ciencia, como sucedía hasta el Renacimiento. Por eso en la parte más entrañable de su pensar queda la poesía como fluir del manantial de ese país que él lleva dentro y donde ha arribado, como bellamente expresa el gran poeta castellano "ligero de equipaje", "casi desnudo, como los hijos de la mar". En ese sentido Martí está en la avanzada de las teorías sobre la ética que en el presente -sobre todo con Wittgestein, Levinas y Derrida- sustenta sus principios en un sujeto sintiente, más que en un sujeto pensante, un sujeto que va más allá del egos y del cogito de la racionalidad occidental moderna, un sujeto que ha lanzado el equipaje del conocimiento y de las construcciones universalistas del mundo moderno en el mar de sus propias contradicciones y ha vuelto los ojos al pasado con la intención de reconstruir la fuente 
primaria donde convergía el ser y la naturaleza, lo uno y lo diverso, donde la humanidad del otro hombre dictaba la ley, esa alteridad incondicional y sagrada que nace de la ética.

\section{Contra el materialismo, el pragmatismo y el individualismo burgués}

A Martí, no le ciegan, como se ha podido constatar, ni el progreso, ni la maravilla técnica porque entiende que aquello que parece más acabado y perfecto en la democracia donde vive, resulta, después de la prueba, padecer muchos de los mismos defectos de sus predecesores europeos. Porque ha vivido en las entrañas de la sociedad norteamericana como obrero mezclado con las multitudes arrastradas en la brega cotidiana por la subsistencia; porque ha visto a los niños vender periódicos con los pies en la nieve y el lujo desproporcionado de los palacios burgueses al lado de los mugrientos lodazales donde se hacinan las multitudes de los desposeídos, entiende que ese modelo no es el que conviene a su América mestiza:

Se pudren las ciudades; se agrupan sus habitantes en castas endurecidas; se oponen con la continuación del tiempo masas de intereses al desenvolvimiento tranquilo y luminoso del hombre; en la morada misma de la libertad se amontonan de un lado los palacios de balcones de oro [...] y ruedan de otro en el albañal, como las sanguijuelas en su greda pegajosa, los hijos enclenques y deformes de los trabajadores [...] Esta contradicción inicua engendra odios que ondean bajo nuestras plantas como la fuerza misteriosa de los terremotos, vientos que caen sobre las ciudades como una colosal ave famélica... ${ }^{49}$

Esta última imagen recuerda el "inmenso hombre pálido" del Prólogo al poema del Niágara, como también el Ángelus Novus del cuadro de Klee que Benjamín utiliza para explicar el "progreso en su Tesis IX. Ambas analogías representan ese fragmento 
problemático de la realidad norteamericana que al poeta se le antoja divergente con las ideas democráticas y el estandarte de la libertad que se iza en todas partes. Hay dos mundos irreconciliables en pugna donde debería haber no más que uno en orden equitativo y justo. Esa colosal ave famélica -junto al inmenso hombre pálido- no son otra cosa que la representación simbólica que Martí hace de la corporación, entidad omnímoda que engendra la miseria y desigualdad que ve crecer a su alrededor en contraste con la acumulación desorbitada de la riqueza en unas pocas manos. Ha visto el proceso político actuando en las elecciones y ha comprendido que el soborno y el fraude han penetrado muy profundamente dentro de las estructuras del gobierno. En la Babel del Norte muere y resucita todos los días y así lo consigna en sus Versos libres de 1882: “ ¡Roto vuelvo en pedazos encendidos! / Me recojo del suelo: alzo y amaso / Los restos de mi mismo; ávido y triste / Como un restaurador un Cristo roto" ${ }^{40}$. Estos son años seminales en la profundización y proyección de su visión integradora, enriquecida con la experiencia que recauda en sus breves, pero fructíferas estancias en países de América, sobre todo México, Guatemala y Venezuela. Aquí igualmente concluye el peregrinaje martiano que ha abarcado Europa, América Latina y Estados Unidos. Ha pasado por los centros políticos y culturales más importantes de su época, al tiempo que ha explorado el mundo colonial. A estas alturas ya tiene una visión completa de su época y ha hecho una síntesis que le permite colocarse por encima de la dialéctica de la Ilustración.

En 1886, da una conclusión importante de sus observaciones al considerar que el país "por el culto desmedido a la riqueza, ha caído, sin ninguna de las trabas de la tradición, en la desigualdad, injusticia y violencia de los países monárquicos" (XI, 335, énfasis mío). Esta conclusión es importante en el sentido de que él detecta que esta 
carencia -resultado del genocidio del hombre blanco sobre los aborígenes del norte, donde residía la tradición- es el germen de una sociedad de hombres vacíos cuyo destino esencial es enriquecerse materialmente a toda costa, aunque tal enriquecimiento implique la deshumanización. El materialismo y el mercantilismo extienden sus tentáculos en el nuevo espacio democrático y entregan así, al pragmatismo, la supremacía ideológica. La conciencia social norteamericana será impregnada de esta filosofía que vendrá como anillo al dedo a las élites corporativas, quienes verán en ella el ideal perfecto para la creación del mito del "sueño americano". Martí entiende que si la señorita "trabaja quince horas para ganar quince centavos" y el obrero no ha conseguido trabajo en medio del invierno porque pertenece a un sindicato, y el juez los sentencia cuando se revelan y la policía los aporrea y asesina "¡América es, pues, lo mismo que Europa! "No comprenden que ellos son mera rueda del engranaje social, y hay que cambiar, para que ellas cambien, todo el engranaje" (XI, 338). Después de ver las componendas políticas, el-mercadeo de los votos, el fraude en las urnas, el cabildeo de los poderosos por mantener y aumentar sus riquezas, la hipocresía de los funcionarios públicos que muestran una cara en la tribuna y otra detrás de bambalinas y "se les ve por las calles despavoridos, cubriéndose las cabezas con los mantos, para que no se les descubra lo vil del rostro" (EMS, 66), arriba a esas conclusiones.

Este panorama lo lleva a cuestionarse uno de los elementos más vitoreados del sistema político norteamericano: la libertad política. Se pregunta, entonces: ¿Será la libertad inútil? ¿No hay virtud de paz, fuerza de amor, adelanto del hombre en la libertad? ¿Produce la libertad los mismos resultados que el despotismo? ¿Un siglo entero de ejercicio pleno de la razón no labra siquiera alguna mejora en los métodos de 
progreso? (75). Porque si la libertad política (que es según expresan los ideólogos burgueses) la expresión más soberana del albedrío humano, y ésta no asegura "la dignidad del hombre", ni una "distribución equitativa de la riqueza", y si el obrero no puede garantizar para él y su familia la subsistencia con decoro y una vejez sin la angustia del desamparo, sino de paz y reposo, entonces algún mecanismo esencial de la democracia está podrido. No obstante expresa su optimismo por el triunfo de la justicia, la equidad y el bienestar moral y espiritual de la democracia. Muchas de las ideas contenidas en este trabajo pudieran cotejarse con las publicadas en cualquiera de los principales diarios de la nación sin que se notara, excepto por el estilo, y cambiando los nombres, marcadas diferencias. Pero lo que reproduzco a continuación es más pertinente aún puesto que, no sólo explica las actitudes entreguistas de algunos políticos e intelectuales hispanoamericanos, sino porque toca uno de los componentes ancilares del discurso de la "civilización occidental", el tan llevado y traído tópico del progreso y la superioridad material. Este análisis de la incapacidad del progreso material para solucionar los problemas vitales del ser humano, es particularmente significativo, si tenemos en cuenta la fecha en que él lo escribe, cuando aún la élite financiera no había descubierto la fórmula de convertir al "ciudadano" de la democracia en "consumidor". Si los versos que analizamos del poema "Dos patrias" constituyen el más incontestable desborde martiano de la modernidad estética -aunque implica mucho más que eso-, este análisis socio-político y económico es uno de los adelantos más audaces del pensamiento martiano en su desborde de la modernidad burguesa.

...cuando se palpó que los inventos más útiles, puestos en ejercicio con abundancia ilimitada en el país más libre de a tierra, reproducen en pocos 
años la misma penuria, la misma desigualdad, las mismas acumulaciones de riqueza y de odio, los mismos sobresaltos y riesgos que en los pueblos de gobierno despótico [...] se han acumulado con el concurso de los siglos; cuando se observó definitivamente que la maravilla de la mecánica, la exhuberancia del suelo, la masa de población, la enseñanza pública, la tolerancia religiosa y la libertad política, combinadas en el sistema más amplio y viril imaginado por los hombres, crean un nuevo feudalismo en la tierra y en la industria, [...] entonces se vio que la libertad política no basta a hacer a los hombres felices, y que hay un vicio de esencia en el sistema que con los elementos más favorables de libertad, población, tierra $\mathrm{y}$ trabajo, trae a los que viven en él a un estado de odio y desconfianza constante y creciente, y a la vez que permite la acumulación ilimitada en unas cuantas manos de la riqueza de carácter público, priva a la mayoría trabajadora de las condiciones de salud, fortuna y sosiego indispensables para sobrellevar la vida. ${ }^{51}$

Más de cien años después de haber sido escritas estas palabras el cuadro de injusticias descritas aquí poco ha cambiado puesto que -como entendía Martí- para eliminar las injusticias, la miseria y las desigualdades hay que cambiar el engranaje que las produce, de lo contrario seguirán reproduciéndose y acumulándose como las mismas promesas incumplidas. El tiempo, ese juez implacable y aleccionador, ha dejado su palabra intacta, porque esa es la naturaleza de la escritura ética, tocar las esencias, la raíz de la verdad y exponerla a la luz para que el poder pueda mirarse en ella su rostro deformado. Iván Schulman, refiriéndose a sus crónicas comenta en Vigencias: Martí y el Modernismo que "para el lector de hoy, familiarizado con la cultura y la sociedad norteamericanas, constituyen un texto social contemporáneo, pues evidencian [...] una vigencia singular". ${ }^{52}$ Más adelante Schulman refiere la anécdota relacionada con la supresión de un fragmento de una de las crónicas de Martí enviadas a Mitre y Vedia, director de La Nación de Buenos Aires porque temía que su misiva "encerrando verdades innegables, podía inducir en el error [entre los lectores bonaerenses] de creer que se abría 
una campaña de denunciación contra los Estados Unidos",53, según declara en carta a Martí. De ahí que -concluye Schulman- son "escritos cuyo discurso es de una vigencia extraordinaria hoy día. Son crónicas que contienen pasajes que describen situaciones o actitudes que desgraciadamente persisten hasta hoy y que revelan hasta qué punto el escritor cubano había entendido las raíces de la vida norteamericana". 54 Al crítico le llama la atención, particularmente, una crónica de Martí que podría aparecer en un periódico de Washington o Nueva York. Comenta que si "en la descripción martiana reemplazáramos las palabras 'en el gabinete de Cleveland' con 'en el gabinete de Clinton' tendríamos un reportaje contemporáneo de indiscreciones políticas y del 'escándalo' Whitewater" $(61)^{55}$. Estas son las palabras de Martí que Schulman cita:

El escándalo -observa el cronista- es donde no pudo sospecharse que tan pronto sería: en el gabinete de Clevelan: Soborno se llama en castellano es recibir paga por abusar de un cargo público en beneficio del que remunera el abuso. El diputado electo por el país para cuidar de sus intereses no tiene el derecho de servir con su puesto a compañías privadas sino cuando de ellas resulta claramente un bien general e indiscutible para el país a quien debe su puesto, y de quien cobra paga. Ese fue el colosal escándalo... [d]el Credit Mobilier en que el mismo Garfield apareció envuelto... (161-62)

Huelgan los comentarios, pero si algún bien puede desprenderse de las citas que ambos hacemos de trabajos como "La procesión moderna", "El movimiento social y la libertad política", "La verdad sobre los Estados Unidos" y "Un drama terrible" es el de constatar de dónde vienen, o dónde está el origen de prácticas políticas y económicas que han ido erosionando, por más de un siglo, los cimientos de la democracia norteamericana hasta convertirla en una "corporocracia" o, como dice Martí, en una tiranía industrial. El soborno de que él habla aquí, cáncer de la institución política -sin dudas en su estado 
embrionario-, hizo metástasis y ha cubierto todas las estructuras gubernamentales de la sociedad norteamericana actual.

Ezequiel Martínez Estrada, refiriéndose a las características de la personalidad de Martí dice que es "un personaje mítico, "revenant"o un "fósil antropológico vivo".Y luego dice que "es anacrónico en cuanto Martí abarca con ávida "libido sciendi et cognoscendi" numerosos compartimientos de los conocimientos humanísticos tal como un gentilhombre del Renacimiento". 56 Pero la idea que más conviene a este fragmento es la de que la sabiduría martiana se expresa "en un repertorio de temas que competen al "hombre antiguo", al hombre religioso, heroico, puro, patriarcal, incorruptible." Dice que "sus virtudes son arcaicas, y el hombre moderno, el norteamericano que emprende y triunfa, es el polo opuesto de ese tipo de personalidades". Para culminar estas ideas dice que "Martí fue engendrado por sus antepasados más que por sus padres" (469).

En su crónica "Una procesión moderna", escrita para reflejar el desfile de los trabajadores del 2 de septiembre en los inicios mismos de esta fiesta popular (1884), al tiempo que describe lo que objetivamente ve, el sujeto narrativo -sin poderlo evitar, como él mismo confiesa- se desliza constantemente hacia la reflexión por lo que deja en la crónica algunas de reveladora importancia. La crónica va de la descripción objetiva y detallada de todo lo que observa a la valoración subjetiva de ideas que, como veremos, han ido madurando en el escritor desde su arribo a Nueva York en 1880. En ella dedica unas páginas a Jay Gould, prominente y despreciable figura en la época:

Un trabajador lleva a cuestas, como carga que lo abruma, al Monopolio, representado en la figura de Jay Gould, gran estratégico de Corporaciones y Bolsas, que en sus manos tiene las bridas de empresas innumerables, y de un lado y otro las guía con goce frío y maligno [...] Con una voz, hace 
surgir un ferrocarril: lo hunde con la otra: si quiere puede detener en un momento, hasta que le paguen lo que le place, todos los telégrafos de los Estados Unidos. Por su poder extraordinario, por la pasmosa habilidad con que lo mantiene, por los medios tortuosos de que se vale sin escrúpulo y por la frialdad de su corazón, atento sólo al triunfo o a la defensa propia, Jay Gould es reciamente odiado... (X, 83)

Martí transfiere analógicamente el color del metal al rostro del sujeto quien para el poeta adquiere un color "cetrino" similar al del metal: "cuando el amor excesivo a la riqueza se apodera del espíritu, produce estos reflejos metálicos". Luego redondea la idea llevándola al plano general de la sociedad: “¡oh, almas infelices, aquellas exclusivamente consagradas al logro, amontonamiento y cuidado del dinero! Han de debatirse en soledad terrible, como si estuvieran encerradas en una sepultura" (84). Este hombre no puede descansar en paz pues ha de velar toda la riqueza que "ha centralizado en enormes compañias, empresas múltiples, las cuales impiden con su inaudita riqueza y el poder [...] que con ella se asegura el nacimiento de cualquier otra compañia [...] y gravan con precios caprichosos, resultado de [...] falseamientos inicuos" (84) las operaciones comerciales del país. "Jay Gould, era reputado como "el peor hombre en la tierra desde el comienzo de la era cristiana". ${ }^{57}$ Para concluir el fragmento añade una de las más audaces reflexiones de la crónica, una que reverbera en otros documentos suyos importantes. "El monopolio está sentado, como un gigante implacable, a la puerta de todos los pobres" (84) imagen que complementa la del "inmenso hombre pálido" del Prólogo al poema del Niágara. O sea, el "gigante implacable" -que es el monopolio-, crea un "inmenso hombre pálido, de rostro enjuto, ojos llorosos y boca seca", personificación de la pobreza y la miseria. Continúa Martí: “Todo aquello en que se puede emprender está en manos de corporaciones invencibles, formada por la asociación de capitales desocupados a cuyo 
influjo y resistencia no puede esperar sobreponerse el humilde industrial...El monopolio es un gigante negro" (84). El gigante negro engendra un inmenso hombre pálido, vestido de negro. Estas analogías migrando de un documento a otro, de diferentes modalidades y épocas da la medida -otra vez- de estar frente a un pensamiento que además de penetrante, y muestra su unidad y consistencia, algo que Foucault elogia y considera debe ser parte de las técnicas discursivas de un escritor. La frase que cierra la reflexión, una vez más forma parte de sus fragmentos ígneos contra-hegemónicos, desafiantes de los meta-discursos y del canon que: "La tiranía acorralada en lo político, reaparece en lo comercial. Este país industrial tiene un tirano industrial" (84; énfasis mío). En síntesis, con esta frase, junto a las que presenta en "El movimiento social y la libertad política" sobre el fraude y la corrupción de la institución política subvierten de plano el discurso del estado moderno y son una contra-narrativa dirigida a cuestionar y desacreditar el soporte esencial de su institución política en la figura del sufragio universal. Habrán de pasar varias décadas hasta que este fenómeno de la penetración y el control corporativos de la esfera política alcance proporciones alarmantes -como referimos- y cobre relevancia en el discurso de la intelectualidad norteamericana y de la crítica y la teoría contemporáneas.

\section{Bancarrota de la tradición cristiana.}

La contra-narrativa hegemónica martiana también opera para el discurso religioso de la tradición judeo-cristiana. Martí consigna que la iglesia ha sido una institución corrupta, degradada en sus esencias, y prostituida al amparo de las estructuras del poder 
del que ha sido aliada incondicional y soporte ideológico por dos milenios. Por eso en el Prólogo al poema del Niágara califica la modernidad de "Ruines tiempos, en que los sacerdotes no merecen ya la alabanza ni la veneración de los poetas, ni los poetas han comenzado todavía a ser sacerdotes" (VII, 224). Pero esta oposición no lo es a la esencia de Dios, o a la capacidad y la necesidad del hombre de mantener su diálogo con la divinidad, es decir su religiosidad esencial. Es obvio, -para quien haya recorrido su escritura- ver que en ella y en él habita el Dios amador, perdonador, ecuménico. Su batalla lo es contra la institución que ha azuzado tantos odios, intolerancias, crueldades, crímenes y genocidios por un período demasiado extenso en la historia de la sociedad. La intensa batalla ideológica que desarrolla durante los últimos quince años de su vida tiene como uno de los fundamentales objetivos "devolver a los hombres a sí mismos”, librarlos de "las filosofías, las religiones, las pasiones de los padres, los sistemas políticos" (231) que lo disminuyen en su esencial naturalidad, lo corrompen y esclavizan y por eso "la tierra ahora es una vasta morada de enmascarados" (231). Porque el hombre descentrado de su divina humanidad lleva una existencia advenediza "y la verdadera vida viene a ser como corriente silenciosa que se desliza invisible bajo la aparente" (231). Este desconcierto espiritual es el resultado de perniciosas doctrinas dadas al hombre como "manjar recalentado" desconectadas de lo real y verdaderamente trascendente del espíritu humano. "Asesino alevoso, ingrato a Dios y enemigo de los hombres, es el que, so pretexto de dirigir a las generaciones nuevas, les enseña un cúmulo aislado y absoluto de doctrinas, y les predica al oído, antes que la dulce plática del amor, el evangelio bárbaro del odio" (231). Hay dos frases claves en este fragmento que son la antítesis la una de la otra: "evangelio bárbaro del odio" vs. "dulce plática de amor". En estos dos planos se 
mueve su contra-discurso religioso. Para él -lo hemos señalado- el amor es la verdadera religión y lo que ha visto en su extenso recorrido por el mundo y por los textos antiguos y modernos es la exacerbación de los odios por motivos raciales, políticos y religiosos. En sus estudios intensos desde las Sagradas Escrituras, hasta los libros de ciencia ve el proceso de degradación sufrido por los principios en los que se funda el cristianismo antiguo. Los ideales de amor, caridad, tolerancia, hermandad y fraternidad humana han sido sustituidos por los dogmas que preconizan un Dios y una fe únicas, superiores a los demás, y en consecuencia, portadores de los criterios nefastos de excepcionalidad, fanatismo y universalidad que son, en última instancia, los fundamentos de la tiranía.

Pero Martí no cree, ni en un Dios tiránico manufacturado por el poder desde los tiempos de Roma para consumo popular, ni en el Dios "Progreso" de la ciencia, prohijado por el poder político - continuación del otro- del estado moderno. Ambos han dejado un legado demasiado funesto para la humanidad. "Como en lo humano todo el progreso consiste acaso en volver al punto de que se partió, se está volviendo al Cristo, al Cristo crucificado, perdonador, cautivador, al de los pies desnudos y los brazos abiertos, no un Cristo nefando y satánico, malevolente, odiador..." (VII, 226). Para Martí que entiende que el progreso humano es reconquistarse, salirse del mal gobierno de las instituciones represivas, el progreso en general está en volver al punto de que se partió. Martí era un temperamento inclinado "particularmente al amor humanitario, a las comunidades y personas -phylia, charis-, pero también a los seres y las cosas, y por eso se les considera de esencia religiosa". ${ }^{58}$ Ahora, la religiosidad de Martí tiene caracteres muy peculiares y siendo una "figura numinosa" es preciso definir el concepto que a él le corresponde en esta dimensión. Sostiene Estrada que según Spranger "el homo socialis se encuentra muy 
estrechamente vinculado al homo religiosus, y que regularmente toda creencia en la perfectibilidad del ser humano, que tiene base hipotética y no científica, sin ser sentimiento mesiánico ni soteriológico comporta una fe de esencia mística" (91). La fe y la religiosidad martianas que nunca pierden su ascendencia ética -ascendencia que viene de la tradición de sus maestros cubanos de adolescencia: Mendive, Caballero, Luz, Varela, se afianza en el presidio y el exilio.

Esta primera exploración de las dimensiones humanas del sufrimiento entre sus hermanos engendrado por el poder colonial muestra la marca ética que caracterizará su escritura en lo adelante. "La moral será siempre para Martí un imperativo de la misma fuerza que el primer mandamiento de la ley mosaica, y que puede expresarse así: "Amarás el bien sobre todas las cosas". ${ }^{59}$ En este caso no se refiere a la moral estatuaria, o institucional, sino a principios inherentes a la condición esencial del ser humano, en otras palabras, la ética incondicionada que exploraremos más profundamente en nuestros capítulos finales. El bien en la conducta martiana está condicionado por el substrato primordial de su ser que es el amor. "El amor era en Martí resultado de su ser, el comportamiento de su persona espiritual y corporal, y pudo haber dicho, como antífona: "Yo no he nacido para el odio sino para el amor" ${ }^{60}$ La honestidad en las creencias, más allá de los formulismos institucionales es algo que también él defiende porque la falsedad de los credos es tan nefasto como la ausencia de fe. "Puede decirse, no obstante, que no era religiosos ni cristiano ni musulmán ni judío, pero que era de tal índole piadosa y comprensiva, venerante y sensitiva, que todas las religiones pueden considerarlo como suyo". ${ }^{61}$ De lo anterior se desprende que el poeta cubano disentía de la institución eclesiástica y sus dogmas, sus sistemas rígidos, sus doctrinas perniciosas y concibe "la 
posibilidad de una iglesia sincrética que una todas las confesiones cismáticas, como se intentó en los orígenes del cristianismo". 62 Todos los intentos desde entonces, pasando por la Civitas Dei de San Agustín hasta las utopías sociales que Etienne Wilson estudia en Las metamorfosis de la ciudad de Dios han fracasado. Martí se refiere en varias ocasiones a "la iglesia natural que se está levantando como árbol que tendrá por copa el cielo, del pecho de todos los hombres a la vez. En la iglesia única, inexpugnable y hermosa, pararán como zorras encadenadas, todas estas iglesias" (XII, 116). La exhortación del cubano es a que la iglesia vuelva a su origen y los dioses a hablar su lengua primera, la de los bosques, los ríos, las piedras, las cosechas, las estrellas, etc. "Porque el cristianismo se siente como al morir, en los umbrales de la iglesia nueva donde, con el cielo por techo se sentará el Cristo católico junto al Cristo hindú, Confusio de un lado y Wotan de otro, sin más clérigo que el sentimiento del deber, sin más candelabros que los rayos del sol, ni más incensarios que los cálices de las flores" (XII, 418). No hay para él necesidad de sectas, ni doctrinas, como tampoco templos erigidos con el sudor de los oprimidos que nunca ven sus plegarias respondidas, ni dignificada su existencia.

Para Martí la religión se concibe de dos maneras: una como creación cultural, expresión de las tradiciones y el devenir de los pueblos, y otra como necesidad innata del ser humano. Así se refiere en varios textos a la "religión futura", una al margen de todo dogmatismo y de toda estructura institucional, donde el hombre pueda expresar ese sentimiento íntimo de amor porque "la religión, está pues, en la esencia de nuestra naturaleza" (XIX, 391), y no tiene nada que ver con dogmas, ni jerarquías que la administre, de la misma manera que no hay autoridades para administrar la poesía del ser 
del mundo. En esta religión futura con la que soñaba Martí el hombre podría expresar su divinidad natural, sin concebir que otro hombre fuese enemigo suyo porque expresare su divinidad de forma distinta; religión sin fanatismos, ni pasiones viles, concebida en el amor, la justicia, la belleza, la libertad, la fraternidad y la hospitalidad, una religión donde pudieran fundirse misterio y razón, naturaleza y espíritu en lo uno y lo diverso. Para esta nueva religión Martí no esperaba -como nos dice Cintio Vitier- "nuevas revelaciones, sino la puesta en práctica de la eticidad innata en el hombre, el ascenso a la conciencia de las masas irredentas y la entrega diaria a la tarea de darle a la vida un sentido trascendente en armonía con el Universo". ${ }^{63}$ La eticidad innata del hombre nos vuelve una vez más al concepto natural y al sentido de trascendencia en armonía con el Universo que es un concepto clave en la teoría ética levinasiana. Es, a la vez, uno de los fundamento de lo que concebimos como el humanismo ético martiano.

Como se ve el sentimiento religioso en Martí está divorciado de toda ceremonia de parroquia o pastoral para encarnar más bien en los sentimientos ancestrales que vieron los teólogos presocráticos y los místicos medievales: el bien, la belleza, la bondad, la fraternidad, la virtud. Y éstos llegan a él, no en reflexión teológica, sino poética, de ahí su pensamiento sentencioso, expresado muchas veces en parábolas: "El mundo / De minotauro yendo a mariposa", "Empieza el hombre en fuego y para en ala", "Yo percibo los hilos, la juntura, / La flor del Universo", "El universo / Habla mejor que el hombre", Viejo nací: ¿Quién soy? Lo sé. Soy todo:- (De Flores del destierro), o "del mismo germen son la miel, la luz y el beso" de "El poeta Walt Whitman". Para Martí existe una religión: "la inconformidad con la existencia actual y la necesidad, hallada en nosotros mismos, de algo que realice lo que concebimos" (VI, 313). Para él "el cristianismo ha 
muerto a manos del catolicismo. Para amar a Cristo es necesario arrancarlo a las manos prósperas de sus hijos" (VI, 313). Lo que rechaza del catolicismo militante es su rigidez, dogmatismo y alejamiento de aquellas nobles ideas de unión y comunión de los hombres con su divinidad. Concluyo este apartado con otro pensamiento suyo que resume su idea espiritual y donde conecta las dos dimensiones fundamentales la esfera, la física y la espiritual: la poesía y la naturaleza:

\begin{abstract}
Las religiones, en lo que tienen de durable y puro, son formas de la poesía que el hombre presiente; fuera de la vida, son la poesía del mundo venidero: ¡Por sueños y por alas los mundos se enlazan!: giran los mundos en el espacio unidos, como un coro de doncellas por estos lazos de alas. Por eso la religión no muere, sino se ensancha y acrisola, se engrandece y explica con la verdad de la naturaleza y tiende a su estado desconocido de colosal poesía. (XI, 243)
\end{abstract}

"Las religiones son formas de la poesía que el hombre presiente". Así fue en el mito, hasta que despojado de su poesía, degeneró en el dogma cristiano.

A lo largo del capítulo hemos visto como el pensamiento martiano desborda en todas direcciones el pensamiento epistémico de la modernidad burguesa. La crítica a la institución científica, al cogito racional, al historicismo lineal, al progresismo teleológico, al pragmatismo, el utilitarismo, al evolucionismo, al positivismo, a la institución jurídica, al discurso teológico y a la corrupción de la institución democrática son las expresiones concretas e incontestables de su oposición a tal modernidad. En ello radica el paradigma de su escritura ética capaz de desbancar todo el discurso euro-céntrico y universalista de Occidente llevado a cabo desde la periferia, donde levanta su discurso anticolonial y antiimperialista, como el mayor impedimento al poder omnímodo del estado moderno. 
'Walter D. Mignolo. "Colonialidad global, capitalismo y hegemonía epistémico" en Culturas imperiales: experiencia y representación en América, Asia y Africa. (Buenos Aires: Beatriz Viterbo Editora, 2005). Es autor del importante libro The Darker Side of the Renaissance: Literary, Territoriality and Colonization en el cual plantea la conquista de América como la cara más oscura del Renacimiento.

${ }^{2}$ Michel Hardt y Antonio Negri. Empire. (Cambridge, Mass.: Harvard University Press, 2000), 75.

${ }^{3}$ Walter D. Mignolo, 74.

${ }^{4}$ Mignolo, 74.

${ }^{5}$ Michel Hardt y Antonio Negri. Empire, 49.

${ }^{6}$ Hardt y Negri, 80.

${ }^{7}$ Hardt y Negri, 81.

${ }^{8}$ Hardt y Negri, 81 .

${ }^{9}$ Hardt y Negri, 81.

${ }^{10}$ Hardt y Negri, 82.

${ }^{11}$ Hardt y Negri, 82.

${ }^{12}$ Hardt y Negri, 83.

${ }^{13}$ Hardt y Negri, 83 .

${ }^{14}$ Hardt y Negri, 84.

${ }^{15}$ Hardt y Negri, 87.

16 José Martí. "La verdad sobre los Estados Unidos" en Ensayos y crónicas preparada por José Olivio Jiménez. (Madrid, Cátedra 2004), 178.

${ }^{17}$ Martí, 294.

${ }^{18}$ Carlos J. Rojas Osorio. Michel Foucault y el pensamiento contemporáneo. (San Juan: Editorial de la Universidad de Puerto Rico, 1995), 131.

${ }^{19}$ Jack Beatty. The Age of Betrayal: The Triumph of Money in America, 1865-1900. (Nueva York, Alfred A. Knopf, 2007), 23. Extenso y profundo estudio sobre la evolución y crecimiento del estado monopolista y corporativo norteamericano que refleja cómo la entidad corporativa se apropia del proceso político con la creación de la institución del cabildeo. Beatty señala cómo entre 1865 y 1900 se produce el triunfo de la institución financiera sobre las demás entidades gubernamentales y cómo la entidad corporativa corrompe el proceso político y aborta, con su poder incontestable, uno de los pocos vestigios de la voluntad popular ejercida a través del voto en las urnas.

${ }^{20}$ Todas las citas de este libro son traducciones mías. 
${ }^{21}$ José Martí. Ensayos y crónicas. Ed. José Olivio Jiménez. (Madrid: Cátedra, 2004), 1 12-113.

${ }^{22}$ Beatty, 17.

${ }^{23}$ Beatty, 24.

${ }^{24}$ Beatty, 24.

${ }^{25}$ Octavio Paz. Los hijos del limo. (Barcelona: Seix Barral, 1974). Aquí debo hacer una pequeña digresión sobre ciertos y recientes usos perversos de la palabra subdesarrollo...El adjetivo subdesarrollo pertenece al lenguaje anémico y castrado de las Naciones Unidas [...] El vocablo no posee ningún significado preciso en los campos de la antropología y la historia: no es un término científico, sino burocrático [...] $\mathrm{Al}$ amparo de su ambigüedad se deslizan dos pseudo-ideas, dos supersticiones igualmente nefastas: la primera es dar por sentado que existe sólo una civilización o que las distintas civilizaciones pueden reducirse a un modelo único, la civilización occidental moderna; la otra es creer que los cambios de las sociedades son lineales, progresivos y que, en consecuencia, pueden medirse. Este segundo error es gravísimo. 40-41

${ }^{26} \mathrm{Paz}, 41$.

${ }^{27} \mathrm{Paz}, 41$.

${ }^{28} \mathrm{Paz}, 41-42$.

${ }^{29}$ Roberto Fernández Retamar. Todo Calibán. (La Habana: Editorial Letras Cubanas, 2000), 18.

${ }^{30}$ Edward Said. Cultura and Imperialism. (New York: Vintage Books, 1993), Todas las citas corresponden a la Introducción. XIII.

${ }^{31}$ Michel Foucault. El orden del discurso. (Buenos Aires: Tusquets Editores, 2002), 39.

${ }^{32}$ Foucault, 41.

${ }^{33}$ Foucault, 41.

${ }^{34}$ Edwar Said, XIV.

${ }^{35}$ Said, XVIII.

${ }^{36}$ Said, XVIII.

${ }^{37}$ Said, XIX.

${ }^{38}$ Domingo Faustino Sarmiento: Obras completas, (Santiago de Chile-Buenos Aires, 1885-1902, t. XLVI), I66-I 73.

${ }^{39}$ Retamar, 51-52.

${ }^{40} \cdot$ Utilizo para este texto "La verdad sobre los Estados Unidos" publicado por Martí en Patria el 23 de marzo de 1894 la selección de Ensayos y crónicas preparada por José Olivio Jiménez. (Madrid, Cátedra 2004), 176.

${ }^{41}$ Martí, 177. 
${ }^{42}$ Materi Calinescu, 264.

${ }^{43}$ Calinescu, 42.

${ }^{44}$ José Martí, 245.

${ }^{45}$ José Martí. "Emerson", XIII, 25.

${ }^{46}$ Susana Rotker. Fundación de una nueva escritura: Las crónicas de José Martí. (Dissertation. University of Maryland , 1995), 303-304.

${ }^{47}$ Edward Said. Representations of the intellectual. (New York: Vintage Books, 1996), 15.

48 En Age of Betrayal: The Triunph of Money in America, 1865-1900, Jack Beaty hace referencia a American Nervousness: Its Causes and Consequences publicado por George Beard en 1883. En este libro el autor introduce el término "neurastenia" para describir como la aceleración del tiempo tradicional, introducido por la modernización, específicamente por la invasión del ferrocarril, crea trastornos fisicos y mentales en el individuo. Luego cita a Barbara Young, quien observa que la estridencia del tren "destroza la división tradicional entre lo privado y lo público". Beard afirma que hoy "un hombre nervioso no puede mirar a su reloj cuando es hora para una cita o un tren se acerca sin que se afecte su pulso", 5.

${ }^{49}$ José Martí. Ensayos y crónicas. Ed. José Olivio Jiménez. (Madrid: Cátedra, 2004), 107

${ }^{50}$ Versos libres (XLI: 181 ). El tema de la muerte es un tema recurrente en todo el poemario.

${ }^{51}$ José Martí, Ensayos y crónicas, 115.

${ }^{52}$ Ivan A. Schulman. Vigencias: Martí y el modernismo. (La Habana: Centro de Estudios Martianos, 2005), 159.

${ }^{53}$ Schulman, 161.

${ }^{54}$ Sculman, 161.

${ }^{55}$ Ivan A. Schulman. Vigencias: Martí y el modernismo. La Habana: Centro de Estudios Martianos, 2005.

${ }^{56}$ Ezequiel Martínez Estrada. Martí revolucionario. (La Habana: Casa de las América, 1974), 466-67.

${ }^{57}$ Jack Beatty, 7.

${ }^{58}$ Ezequiel Martínez Estrada, 91.

${ }^{59}$ Estrada, 93.

${ }^{60}$ Estrada, 93.

${ }^{61}$ Estrada, 99.

${ }^{62}$ Estrada, 100.

${ }^{63}$ Daisu Ikeda y Cintio Vitier. Diálogo sobre José Martí, el apóstol de Cuba. (La Habana: Centro de Estudios Martianos, 2001), 220. 


\section{Capítulo IV.}

\section{Arqueología de la tradición. La voz de su "América mestiza"}

"Ni el libro europeo, ni el libro yanqui daban la clave del enigma hispanoamericano".

"Por eso el libro importado ha sido vencido en América por el hombre natural. Los hombres naturales han vencido a los letrados artificiales. El mestizo autóctono ha vencido al criollo exótico. No hay batalla entre la civilización y la barbarie, sino entre la falsa erudición y la naturaleza".

\section{José Martí "Nuestra América"}

\section{Los estudios culturales y el discurso martiano de la autoctonía}

El discurso martiano en defensa de las culturas aborígenes de América -su discurso de la autoctonía- que es un discurso integral, paradigmático y germinador de su visión americanista, entra en el dominio de los estudios culturales, disciplina que ha ocupado a la academia anglo-americana por las últimas dos décadas. Martí no se aproxima al pasado indígena como el arqueólogo occidental, como una mirada racional, sino más bien desde la perspectiva y con la visión del otro. Desde dentro del fenómeno crea un precedente revolucionario en el ámbito de los Estudios culturales, en la indagación de las formaciones culturales de las civilizaciones precolombinas. El viaje martiano hacia el interior de estas civilizaciones no es descubrir tesoros perdidos, pictogramas arrancados del Popol Vuj o deidades mutiladas por la herrería cristiana. Él busca suplantar el saber europeo por el saber americano: "La historia de América, de los 
incas acá, ha de enseñarse al dedillo, aunque no se enseñe la de los arcontes de Grecia" (VI, 18). Es decir, suplantar el texto racional cartesiano por el texto aborigen, el libro cerrado por el libro abierto, el Dios castigador y perdonador por el Dios que se crea a sí mismo. Si algo intenta Martí -como condición esencial para la verdadera liberación del continente- es devolver a América su historia original, su cultura original, su cosmovisión original, en otras palabras -lo dice muy claro-, devolver la página que la conquista había arrancado de la historia universal. Por tanto su aproximación es más que todo integradora, que según Lezama es el sentido americano de contra-conquista. Desenterrar, acariciar, dignificar, equilibrar, armonizar, integrar el pasado con el presente en la fragua del amor: esa es su ciencia.

Los estudios culturales han desarrollado un debate en torno a cuál es y debe ser "el objeto de estudio", el campo epistemológico de tal disciplina. Algunos como Chris Norris - defendiendo su especialización- la separan de la filosofía, argumentando que ésta no debe disolverse dentro de un campo cuya episteme no ha sido demarcada suficientemente. La posición de Norris es la típica de la institución académica elitista que, por un lado vela porque la pureza de su disciplina no sea invadida por otras no suficientemente prestigiadas por el canon, defendiendo así la cuestionable especialización como garantía de prestigio institucional. Las posiciones filosóficas exclusivistas y pragmáticas se deterioran como consecuencia de la irrupción, hacia finales del XIX de disciplinas como el psicoanálisis, el marxismo, la antropología, la lingüística y otras que producen una considerable ampliación del campo epistémico moderno. A ello se suma el trabajo de ciertos filósofos, entre ellos Nietzsche quien devuelve la cultura al terreno de la filosofia o viceversa y quien, además es uno de los primeros en diagnosticar la 
patología nihilista y la condición de crisis constante de la cultura occidental. En la segunda mitad del siglo XX -aunque venía fraguándose desde la primera- la irrupción de las teorías del lenguaje y de la teoría literaria produce un cambio sustancial en el pensamiento filosófico, resultando en una hibridez discursiva que emerge con fuerza sobre todo en la escuela francesa y en cierta porción de la inglesa y norteamericana. Los pensadores no discriminan en el uso de sus discursos en el anhelo de explicar los complejos procesos socio-políticos y económicos, pero sobre todo culturales que produce la modernidad. De modo que la filosofia, como en sus orígenes, vuelve los ojos a las producciones artísticas y literarias y éstas comienzan a abandonar las posturas limitadas del esteticismo a ultranza donde habían encontrado confortable refugio: “... en el curso del presente siglo (XX) se dice que la crítica se había retirado dentro de la academia, donde fue domesticada en un discurso profesional y apolítico. Sólo en el curso de las últimas décadas esta tendencia ha sido revertida"1.

De estas circunstancias emergen los estudios culturales, que, por supuesto han tenido que resistir el bombardeo de las posturas de la especialización desde ambas polaridades: la filosófica y la estética. Aunque no es propósito de mi tesis analizar los procesos germinales de la post-modernidad, va siendo cada vez más claro que este elitismo disciplinario que da lugar a la escisión de los campos epistémicos de la filosófica, por un lado, y el arte y la literatura, por el otro, dejó el terreno abonado -a falta de una crítica ética- para la irrupción de un fenómeno como la post-modernidad, manufacturado en sus constitutivos esenciales como meta-narrativa del poder. Las expresiones artísticas apuntaban hacia la eticidad como contra-discurso moderno. El poder hegemónico puso en práctica sus estrategias político-culturales para abortar una 
post-modernidad que fue una pérdida enorme de energía y un alejamiento de la ética. Por eso Martí, al entender estas carencias y contrario a todo elitismo filosófico o artístico puede dar su tan radical vuelta de tuerca, y, al margen de la modernidad y contra ella, inaugurar su discurso ético en el que arte y filosofía, literatura y ciencia, antropología y cultura siguen integradas. Esta independencia hermenéutica y epistemológica martianas le permite continuar ejerciendo la crítica de todos los meta-discursos desde su escritura porque sabe que la dignidad del creador se juega contra el poder y no a favor de él. Martí tiene un concepto muy elevado del arte como forma de llegar a la verdad: "El arte es una forma del respeto", de ese respeto entrañable del otro en lo que tiene de distinto, porque para Martí -nos dice García Marruz- lo que cada hombre tenía de distinto era lo que tenía de original y creador y ya se sabe que lo creador era para él fuente de virtud"2.

En su aproximación al estudio de las culturas precolombinas piensa, fundamentalmente, desde la poesía y más, desde la mito-poesía de su cosmovisión en la que entran elementos de las culturales orientales más antiguas, así como también de la cultura náhuatl y maya-quiché. Si consideramos que la virtud es uno de los fundamentos de la ética, y para él la virtud es lo original, y si lo que defiende es la originalidad de las culturas aborígenes de América frente al discurso racionalista occidental, (racista y exclusivita en su fundamento), entonces tenemos una imagen bastante precisa de por qué su discurso de la autoctonía es esencial y revolucionariamente ético y por qué adelanta con él las posiciones y tendencias que asumirá la crítica literaria y la filosofía contemporáneas desde segunda mitad del siglo XX. Contraria a la visión de Norris está la de Simon Critchley ${ }^{3}$ que lo mismo que el poeta cubano, parte de un principio ético que nada tiene que ver ni con la ética protestante -originada en su natal Inglaterra- ni con la 
moral de la tradición judeo-cristiana. Su visión emana de los conceptos de Levinas y Derrida, dos de los filósofos más revolucionarios en el ámbito del pensamiento ético del siglo XX. Su estudio de ambos pensadores constituye parte del fundamento teórico que utilizo para la ética martiana. De ahí que me limite aquí a esbozar brevemente algunas ideas de Critchley en relación con los estudios culturales que indican que la filosofía contemporánea y la estética han llagado a cruzarse de nuevo a través de la ética, que es lo que ya había hecho Martí en su momento. Critchley no ve la filosofía como una disciplina exclusivista, intelectualmente superior que debe atacar a los estudios culturales acusándola de ser una disciplina incompleta cuyo objeto de estudio no está suficientemente limitado, o cuya agenda es política. Él cree en el análisis interdisciplinario y más aún, cree que esta segregación del conocimiento es una de las falacias de la modernidad, que se encarga de dinamitar la figura del intelectual comprometido con su realidad y en constante vigilia de las maniobras hegemónicas del poder. Por eso su aproximación al estudio de la cultura es desde la hibridez discursiva y defendiendo la legitimidad de los estudios culturales como una demanda político-social, y ético-estética en el horizonte de un estado moderno en crisis.

Para Critchley "la filosofía es y debe ser una meditación del significado de la cultura, una meditación sobre la cultura" (59). ${ }^{4}$ Puesto que si la cultura es la manifestación de las necesidades espirituales y la configuración en formas artísticas de las necesidades de un pueblo, expresiones en las que emergen las esencias originales y los rituales de la tradición grabados en el inconsciente colectivo de éste, entonces la filosofia no puede estar ajena a esas expresiones y a esas formaciones de conciencia. Si la dominación de un pueblo no puede ejercerse fuera del ámbito de su cultura, la filosofía 
debe participar de las estrategias que garantizan la defensa de los espacios de soberanía y libertad. La filosofia "puede revelar la contingencia de esos significados y prácticas culturales y la naturaleza de las construcciones hegemónicas les imponen" (59). Critchley refiere que los filósofos han recurrido siempre a la literatura para derivar de ésta los significados de ciertas expresiones culturales. En tal sentido usa el ejemplo de Hegel -los ejemplos en este sentido son numerosos- cuando analiza El sobrino de Rameau, (un texto codificado, secreto) de Diderot en el cual el filósofo alemán "ofrece un diagnóstico de la cultura de la Ilustración" (60) e informa como la sociedad puede evadir esa cultura de decadencia. "Lo mismo se puede decir de alguien como Nietzsche, quien medita sobre el sentido de la cultura considerada por él una cultura [la de la modernidad] del nihilismo (la fuente de lo cual es la cristiandad). Parte de la filosofía es el estudio de la cultura (60). Más adelante menciona el caso de Rousseau quien en su Discurso del origen de la desigualdad, habla de las patologías culturales, entre ellas la relacionada con la posesión de propiedad, que, a propósito, en el caso de América, se constituye en una de las prácticas falaces de Occidente para legimtimizar la conquista y colonización de los territorios indígenas.

Una de las ideas manejadas por el filósofo inglés es que la escritura es un modo de reducir la falta de libertad -tarea de Martí de toda su vida- y lo contrario es un ejercicio de legitimación de la profesión y no un compromiso con la verdad. Para él, entonces, los estudios culturales son un proyecto político muy vinculado con el concepto hegemónico y su fuerza normativa. De ahí que entienda que."la pregunta teórica clave es como vincular la ética y la política a través de esta noción de la hegemonía. Para mí en la base de toda noción normativa se da una experiencia de lo que llamo una demanda ética" 
(64). También para el poeta cubano la defensa del aborigen americano es una demanda ética que debe estar en la base de la transformación de la conciencia latinoamericanista, en la evolución del ser colonial al ser original, lo que yo llamo el viaje invertido, hacia el pasado y hacia el interior del sujeto americano arcaico. Una de las sorpresas más agradables que recibe Critchley en su vínculo con los estudios culturales surge cuando asiste a una importante conferencia sobre esta disciplina en la que descubre que había toda una sección dedicada a Levinas, el filósofo contemporáneo más importante de la ética y a quien él había dedicado, lo mismo que a Derrida su tesis de doctorado. La relación establecida entre la ética y los estudios culturas le demuestra que esto no es sólo "un proyecto político, o de que si lo es, en el centro de ese proyecto hay alguna forma de demanda normativa, alguna forma de demanda ética, de visión ética" (65). Es interesante acotar que Critchley es un filósofo que desaprueba el postmodernismo por su escape -a través de la ironía perpetua- de los problemas cruciales de la sociedad contemporánea. Le parece que los estudios culturales deben dirigirse a esclarecer un mundo que es cada vez más oscuro, sobre todo a partir del 11 de septiembre que para él "es el momento en que la globalización y el neo-liberalismo se hermanan" (74). Asimismo opina que vivimos momentos en que es necesario, como nunca antes, la honestidad intelectual y el compromiso con las causas de justicia y equidad antes de que sea demasiado tarde. Estas ideas enaltecen la dimensión ética y revolucionaria de Martí quien vio con claridad desde el siglo XIX que las entrañas del Imperio eran algo oscuro y que había que ponerse del lado de los humildes antes de que el monopolio extendiera sus tentáculos a la esfera militarista para comenzar su aventura imperial y retornaran los tiempos de Roma y la Edad Media lo cual evidencia cuan profundo podía penetrar su mirado órfica en el futuro. 
De manera que la demanda de la filosofía contemporánea y de los estudios culturales es la misma que desde la escritura ética hiciera Martí hace más de cien años.

\section{La voz de la "América mestiza".}

La mentalidad europea, plagada de fantasías utópicas, vuelca en el Nuevo Mundo un ser humano violento, fanático, militarista y desequilibrado que trae consigo todas las frustraciones resultantes de la irrealización de las promesas mesiánicas y utópicas de su tradición cultural y religiosa. Las nuevas tierras a las que arriba se abren ante sus ojos con el esplendor de la fábula edénica. Un paisaje tan exótico, una naturaleza tan imponente, nunca vista, es el lugar ideal para situar todas las criaturas fabulosas de sus fantasías milenarias; es el espacio perfecto donde anclar su discurso del deseo. Para los europeos estas criaturas aborígenes serán, para su ideología fanática, fáciles presas al sometimiento y esclavitud, pues carecen de "progreso", de lengua civil y no conocen al Dios de la divina providencia. No están investidos de la gracia e inteligencia necesarias para construir el espacio "civilizado". A los ojos de los conquistadores serán inferiores porque son diferentes, serán bárbaros porque son naturales, serán brutos porque no entienden la lengua del imperio. Esa mentalidad intolerante y violenta, forjada en un enfrentamiento de siglos con los mundos árabe y judío, -que culmina en la persecución y expulsión de éstos de la península-, esa mentalidad guerrera, cerrada a la alteridad, descargará sobre la raza indígena, toda su brutalidad y su decadencia moral. Los primeros documentos escritos por el "hombre blanco" degradan el ser de los aborígenes americanos, lo hace extraño a la humanidad occidental, lo rebaja a sub-humanos para poderlo esclavizar y 
convertir con sus prácticas inquisitoriales. El cuerpo indígena pasa a ser el espacio de los nuevos signos, del nuevo texto donde la narrativa colonial opera sus inscripciones. Los signos nefandos que inscribe se convierten, poco a poco, en los nuevos mitos, a veces paradójicos de Occidente: el mito del buen salvaje y del caníbal, del hombre dulce y del bruto, del hombre bestia. Así podemos leer cosas como esta: "Entendió también que lejos de allí había hombres de un ojo y otros con hocicos de perros que comían los hombres y que en tomando uno lo degollaban y le bebían su sangre y le cortaban su natura" (54). ${ }^{5}$ De la versión literaria que de ellos se forman, de su bestialidad meta-ficticia nace la necesidad de exterminarlos. De ahí que la población aborigen del Caribe haya sido diezmada en su casi totalidad. Una de las pocas voces occidentales que disienten de estas pre-fabricaciones fantásticas de la conquista es la de Miguel de Montaigne, -escritor instaurado en el centro del mundo renacentista europeo- quien en su ensayo "De los caníbales" analiza cómo a través de la historia los invasores han llamado bárbaros a los invadidos y, que incluso, esa práctica se remonta a los griegos quienes llamaban "bárbaros" a todos los extranjeros. En este ensayo nos dice que "llamamos barbarie a lo que no entra en nuestros usos. En verdad no tenemos otra medida de la verdad y la razón sino las opiniones y costumbres del país en que vivimos y donde siempre creemos que existe la religión perfecta, la política perfecta". El no "saber" de los indígenas, o su "saber natural" fue, para los invasores racionales, su pecado capital, a pesar de que en el fondo de su tradición cristiana y en su subconsciente ese saber o estado edénico era el que buscaban. Según el hombre blanco, los aborígenes no sabían de guerra, ni de armas, ni de religión, ni de ley. Para ellos estas criaturas sin razón, sin conocimiento, eran los perfectos ejemplares, la tábula rasa donde inscribir sus utopías. Al saber natural indígena, 
opusieron el saber racional occidental arrogante, racista y fragmentado. Roberto

Fernández Retamar ha recogido en Todo Calibán, la torcida historia de la superioridad europea sobre las culturas autóctonas, que es parte de lo que alimenta el euro-centrismo y el universalismo de Occidente. Hablando de la palabra "raza" dice que éste término:

devino muy importante, porque aunque los seres humanos han sabido siempre que hay entre ellos notorias e intrascendentes diferencias somáticas (¿cómo no evocar el Cantar de los cantares dedicado a una mujer negra?), sólo a partir de 1492, al iniciarse el saqueo del resto del mundo por Occidente, y con la finalidad de pretender justificar esa rapiña sin igual, se postuló que tales diferencias implicaban significantes fijos de significados menos fijos, y que esos significados eran positivos en el caso de los de piel "blanca" (de modo más realista, Shaw y Chesterton sugirieron denominaciones como "marrón claro" y "rosado", pues ¿quién rayos ha visto un ser humano fantasmalmente blanco?) y negativos en los demás casos, considerados "coloreados.

Martí, desde su visión americanista, observando la hibridez racial presente en su continente define la composición étnica de América como "mestiza". Este mestizaje es el resultado de la integración en un mismo tronco de varios tipos de seres humanos que han convergido en el espacio territorial que los europeos bautizan con el nombre de América. Con el fin de diferenciar las dos Américas, Martí denomina a la del norte la "América europea o sajona" y a la otra conformada por la familia de pueblos hispanizados, la "América mestiza", para luego explicar el proceso de transculturación que se produce en el continente y su visión crítica de tal proceso:

Interrumpida por la conquista la obra natural y majestuosa de la civilización americana, se creó con el advenimiento de los europeos un pueblo extraño, no español, porque la savia nueva rechaza el cuerpo viejo; no indígena, porque se ha sufrido la ingerencia de una civilización devastadora, dos palabras que, siendo un antagonismo, constituyen un 
proceso; se creó un pueblo mestizo en la forma, que con la reconquista de su libertad, devuelve y restaura su alma propia. (VII, 98; énfasis mío)

Este proceso, en la visión martiana es devastador en tanto se constituye sobre una negatividad al no seguir un curso natural o armónico de mutuas influencias, sino al darse en la aniquilación de los elementos primarios del espacio invadido y la inserción del cuerpo foráneo "civilización". Este choque violento -que en esencia es portador de desequilibrio y entraña una sumisión- de factores ontológicos y epistemológicos ajenos, extraños y problemáticos, de civilizaciones que además poseen una cosmovisión del mundo y de la vida diametralmente opuesta, es catastrófico para el espacio colonizado. Este (des)encuentro entre dos culturas que están en las antípodas la una de la otra genera ineludiblemente un nivel de violencia aniquilador, paralizador, deformador. Por eso Martí insiste que "la savia nueva, rechaza el cuerpo viejo". La negatividad del proceso resulta de una índole devastadora por el factor que predominante en el proceso del (des)encuentro: la diferencia de cosmovisión. Lo que "ellos" llamaron el "Nuevo Mundo" vivía aún un ciclo cosmogónico, no había modernizado su naturaleza, no la había degradado, sino por el contrario, seguía siendo sagrada y en ella aún habitaban sus divinidades; no estaban contaminados con el virus del progreso, ni con las escatologías milenaristas. Para los aborígenes de América las formas de lo sagrado habitaban todas las formas de la vida.

En cambio la "Vieja Europa" había destruido y expulsado sus divinidades agrarias de la ecumene, había sustituido el ser por la historia, y más trágico, habían inaugurado la modernidad, etapa histórica de perpetua crisis, cuyo aparato hegemónico sólo puede sobrevivir en la colonialidad. Es decir, lo que sucede en el espacio americano es la 
imposición violenta de una cosmovisión decadente, nihilista, falaz y determinista, desconectada de lo real; a una civilización que posee una cosmovisión conectada al ser, a lo real y al sentido trascendente, cosmogónico de la existencia humana y que se sabe parte y no centro del proceso de la vida. Es imaginable la agonía del "hombre natural" siendo sometido por la técnica a ser "hombre civilizado". En ello radica la contradicción a la que hace referencia Martí en el pensamiento anterior. Él entendió muy bien en su tiempo que lo que los decadentes europeos llamaban "civilización" equivalía a colonialismo y a imperialismo, es decir a barbarie. Ese entendimiento martiano es uno de sus más preclaros a la teoría y la crítica contemporáneas. Hoy forma parte del discurso de los estudios culturales, del discurso filosófico - especialmente en el ámbito de la éticadel discurso antropológico, artístico y literario.

Ahora bien, la definición de mestizaje que Martí hace no responde a una fórmula racial o de identidad étnica solamente. Tal postura sería reducir su pensamiento a una postura determinista que no estaba en su horizonte epistémico. La concepción martiana del espacio cultural que él denomina "América mestiza" entraña, fundamentalmente, esencias de un modo de ser otro, en un espacio y un tiempo otros, a despecho de haber sido insertado en la modernidad por la fuerza. En otras palabras, el mestizaje martiano es un espacio altérico, dialógico, abierto a la diferencia, a lo heterogéneo, pero, sobre todo, portador de una raíz distinta de la del espacio colonial. Por eso se le opone en la esencia, aunque acepte la forma. Porque en el fondo de este mestizaje lo que subyace es una ontología no contaminada - como nos dice Eliade ${ }^{8}-$ con el devenir, no un discurso teleológico, porque -como señala Martí- "la inteligencia americana es un penacho indígena", no una biblioteca y ese espacio con la reconquista de la libertad "devuelve y 
restaura su alma propia". Este concepto es clave en su contra-discurso y no responde exclusivamente a la visión moderna como veremos. La realidad hispanoamericana muestra que, aún con todos los relatos que la modernidad ha insertado en su espacio cultural, su alma original sigue latiendo en el subconsciente de la raza puesto que la libertad ha sido aparente y no real. Pero a nivel periférico o en el sub-texto del espacio mestizo sigue produciéndose una resistencia a la linealidad y al progresismo desarrollista moderno.

De manera que la "América mestiza" de Martí no es sólo un espacio geo-político, sino, y más que todo, una subjetividad desafiante de la episteme universalista eurocéntrica, en la que palpita un espíritu ético más que lógico, una cosmovisión más que una filosofía, un ser natural más que un ser logo-céntrico. Y ese espacio está pensado desde la cosmovisión aborigen, no desde la filosofía cartesiana y en eso radica la novedad martiana al igual que su vigencia. De esta convicción -resultado de una seria arqueología y un profundo estudio de la herencia cultural aborigen de América-nace su resolución de reinsertar en la historia moderna esa página que la colonización le robó al continente mestizo. De ahí que Martí declare que: "Hay que devolver al concierto humano interrumpido la voz americana, que se heló en hora triste en la garganta de Netzahualcóyotl y Chilam; hay que deshelar, con el calor de amor, montañas de hombres; hay que detener, con súbito erguimiento, colosales codicias" (VII, 285). En su poético reclamo - evidencia de su inquebrantable optimismo y su energía revolucionaria- queda claro que la raíz de las civilizaciones autóctonas, a despecho de toda la violencia y las tácticas empleadas por la colonización para borrar todo vestigio, a despecho de toda la contaminación que sufrieron, su espíritu aún palpita por debajo del ropaje extranjero. La 
misión que aguarda a los pueblos latinos es deshelar, "con el calor de amor" esos signos enterrados en el subconsciente de esas "montañas de hombres".

\subsection{El viaje invertido. El arcaico profundo.}

Martí, digámoslo en principio, -el americano de médula arcaica- es el primer punto de rotación de un nuevo paradigma ontológico y epistemológico que abre el nuevo espacio que llamo de la Eticidad poética, en el cual el discurso de la tradición -de la alteridad- se constituye como eslabón primordial. A partir de entonces, y sabiendo que su escritura no será copia de modelos foráneos, ni rendirá culto a ningún Dios tutelar sino, por el contrario, se levantará como un contra-discurso desafiante del canon y de los relatos modernos, el espacio donde su espíritu hallará el equilibrio, la armonía y la sustancia ética que necesita es en el pasado de las civilizaciones de su "América mestiza". Ese será, entonces su loucus ameunes, su arcadia, su utopía. Mientras más entra en el mundo primordial americano, más se aleja del mundo moderno que encuentra ruin y que sabe portador de una crisis cuto germen es su propia ideología.

Si como afirman los más preclaros estudiosos de ésta etapa histórica, la modernidad se encarga de aniquilar la tradición y el pasado para inaugurar constantemente la novedad, si su realización se erige sobre las ruinas de la otredad, entonces, ¿qué tiene que ver Martí con la modernidad? Todo en Martí tiende al origen, a la raíz, a lo primigenio. Su viaje no es hacia delante, siguiendo la línea ciega del historicismo progresista occidental, sino en espiral, o quizás más exactamente, su viaje es

orbital. Martí se detiene, mira desde su cumbre las dos Américas, y a la vieja Europa y 
hace su síntesis simbólico-analógica de la que luego emergerá su cosmovisión ecuménica. Su reencuentro con América, después de haber leído el texto cartesiano, abre el camino de su discurso arqueológico. México, Guatemala y Venezuela lo sitúan en la órbita de lo que también llama sus "patrias azules". En estos espacios comienza su exploración del pasado ancestral, e inicia su labor de desenterrar los códices legendarios de la "raza cósmica". Da inicio a su excavación del pasado remoto, pero no en busca de lo exótico para decorar sus textos, ni tampoco con la mirada del viajero occidental, que colecciona impresiones e impone su logos racional. Él busca lo autóctono en el patio de su casa. Su viaje no es de placer, o de fuga. Su viaje es doloroso, entrañable, desgarrador, amoroso. Va con el firme propósito de reconectar los hilos rotos por la cerrajería y la pólvora de los conquistadores. Su lectura por tanto no arranca, ni en el positivismo, ni en el cientificismo progresista moderno. Su lectura no es al modo de los antropólogos que hasta la misma primera mitad del siglo XX, contemplaban las ruinas desde una postura racional, monológica. Su lectura es polifónica, como hará la antropología y sus ciencias afines, sobre todo a partir de Levi-Strauss. A través de los símbolos y las analogías va penetrando los textos mítico-simbólicos de las civilizaciones aborígenes. De ahí que su lectura será desde la poesía (ya sabemos que en ésta domina la polifonía), abierta a la diversidad de ese pasado mítico-poético. Por eso Mañach lo llama el arcaico profundo. Cuando Martí comienza a copiar la palabra que no envejece en los archivos profundos del inconsciente y desciende a los abismos donde yacen los mitos y los símbolos para activar los arquetipos, se convierte en lengua de la tribu, en el chamán, el taita, el escriba, el que regresa desde el futuro. Por tal motivo su viaje no es histórico, sino mitológico, como el de Netzahualcóyotl. 
En "Nuestra América" - de acuerdo al criterio de Julio Ramos-" "Martí propone la inversión de ese viaje importador que postula la necesidad del olvido de la tradición". ${ }^{10}$ El colonialismo trata de imponer su marca cultural en el espacio colonizado, no sólo a través de su lengua, sino además a través de sus instituciones y costumbres. A pesar de que el poeta cubano ve la realidad de América Latina como una realidad "descoyuntada", según Ramos "en él la unidad del "nosotros" se construye como respuesta a un caos y a una desarticulación"11 (372), a diferencia de Sarmiento quien intenta ordenar ese caos con un "ellos, (Europa y Norteamérica) creadores del discurso racional, de "civilización" y "progreso".

Para Martí, el caos no es tanto efecto de la tradición, como pensaba Sarmiento, sino de la exclusión de las culturas tradicionales del espacio de la representación. Es decir, Martí postula un "nosotros" latinoamericano hecho precisamente de la materia excluida por el discurso modernizador. Para Martí había que conocer al otro excluido y aplastado - en esa época de Darwinismo social generalizado [...] Martí propone la autoridad de un nuevo saber, el saber de las raíces, de la tradición autóctona [...] Si en Sarmiento el desplazamiento del viaje, en la figura del transporte, era una metáfora matriz, un ícono del discurso, en Martí domina la metáfora del árbol - el árbol genealógico, familiar - como figura estructurante. Ya notaban Deleuze y Guattari la importancia del árbol como metáfora clásica de un saber estable y estabilizador, firmemente territorializado. ${ }^{12}$

El dominio de lo natural en Martí -la metáfora del árbol, de la raíz-, su cuestionamiento de "la urbe antiática" y su poematización de la naturaleza en estrofas clásicas como hace en Versos sencillos lo convierten en un ser extraño a sus contemporáneos, algunos de los cuales, interpretando estos signos de manera contraria, lo ven como un conservador, incluso algunos lo clasifican como un postromántico o un pre-modernista. Lo cierto es que estos críticos de Martí leían el texto de la superficie, el que lee el lector atontado por 
el ruido de las locomotoras o lee con las opiniones de los "sastres en literatura", que leen los retazos. Claro está esa lectura no es integradora, la que se hace con la mirada órfica del poeta que ha descendido al círculo primordial y pude volver al pasado con las armas del presente para alumbrar el futuro.

Esto es muy interesante si se tiene en cuenta que la modernidad, por primera vez, estaba yendo disparada al futuro sin ninguna autoridad reconocida. O sea, ya no se paraba, como en etapas anteriores, sobre los hombros de los antiguos clásicos, pues se había agigantado ella misma y veía por encima de las montañas sin apoyo, sobre sus propios pies. Por tanto, no necesitaba ya del sabio consejo de los antiguos maestros porque encontraba todo en su propia reinvención. Martí no acepta este dictum porque sabe, como poeta veedor "en el fiel de la balanza", que el pasado no se puede cerrar, excluir o desechar sin que se produzca una ruptura violenta -el colonialismo lo prueba--, sin que se desequilibren y desarmonicen los elementos esenciales que conforman el complejo tejido de la sociedad humana. No desvaloriza lo viejo, por el contrario, encuentra en ello lo sagrado y la misma fuente de lo nuevo. Cuando habla en "Antigüedades mexicanas" de nuevos descubrimientos arqueológicos elogia "las veneradas profecías de aquel moisíaco apóstol que fue como el Confusio de los yucatecos, Chilam Balam, anciano y virtuoso" (VIII, 328). Nótese que junta ancianidad y virtud, y que la comparación del sacerdote maya no la hace con ninguna jerarquía occidental, sino con un sabio oriental. Por esa misma razón es también es capaz de llegar a escribir una poesía despojada de toda retórica, rozando lo inefable de la más compleja sencillez, tocando las esencias del ser doble hombre-naturaleza, a través de formas clásicas como en Versos sencillos, considerado una osadía artística para su tiempo que 
sólo hoy comienza a develar su verdadera trascendencia. Según Cintio Vitier es el libro del Pentecostés.

Ahora bien, para llegar a comprender en todo su misterio el sentido que tiene la caracterización de arcaico profundo que Jorge Mañach le señala a Martí, se hace necesario penetrar las cavidades profundas de un ser en el que se constituye una compleja subjetividad, muy extraña al hombre de su tiempo y aún enigmática en el nuestro. En este intento de acercarnos a dicha subjetividad resulta de gran utilidad el análisis que de su perfil psicológico hace Ezequiel Martínez Estrada en su Martí revolucionario. Este no agota las dimensiones múltiples de esta personalidad -que aguarda un exhaustivo y sistemático estudio- pero es una de las más cordiales y amorosas que se han hecho y alumbra espacios vitales del ser martiano, sobre todo en lo que se refiere al anacronismo de su personalidad. La primera impresión del crítico argentino es que Martí sobrepasa la medida del hombre moderno, que se asemeja más a los héroes antiguos y que "se diría un personaje mítico, "revenant" o un fósil antropológico vivo" $(465)^{13}$. Después continúa diciendo que era portador de una cultura humanística "tal como la de un gentilhombre del Renacimiento" (466). Sin embargo, al tiempo que compara a Martí con un León Bautista Alberdi, un Baltasar de Castiglione o con un Desiderio Erasmo, también nos sugiere que en el Renacimiento hubiera podido parecer igual de anacrónico puesto que su personalidad individual -típica de esa época- cedia a la personalidad colectiva que es la personalidad consumida por la pasión de la libertad y el bienestar común. Ya apuntábamos en el capítulo primero que él no participó de las preocupaciones de la moda, ni del snobismo tan característico de su época y que su vida fue ascética en cuanto vivió desinteresado de todo aquello que no fuera lo absolutamente necesario para la 
subsistencia decorosa. Es decir, hasta aquí ya podemos señalar tres características típicas del hombre moderno ausentes de la personalidad martiana: rechazó las modas y el snobismo a cambio de una escritura comprometida con "los pobres de la tierra"; el individualismo burgués a cambio de la hermandad y la fraternidad humanas y el enriquecimiento material por "la justa pobreza" que señala Lezama a propósito de Martí. En tal sentido "nos pudre el dinerismo" es una de las frases que acuden a la mente cuando se piensa en el sinnúmero de ocasiones en que se pronunció contra esa actitud materialista del self-made man, del hombre máquina, desdeñoso de todo lo estético, lo espiritual, lo artístico, que llega incluso a considerar fuera de la psicología del hombre emprendedor, fuerte, masculino, utilitario moderno.

Martínez Estrada considera que "sus virtudes y dotes provienen de un estrato mucho más hondo que su organismo y su ser corporal como si las adquiriera del depósito ancestral de sus antepasados más remotos" (467), con lo cual nos remite a los arquetipos del inconsciente de Jung que referiremos adelante. Para Estrada Martí "es un intuitivo, poseedor del tacto fisiognómino que llamaba Spengler y de "doble vista" que Balzac comprobaba en sí [...] una persona cuyas actividades responden más al instinto o al saber ancestral de la experiencia que a la razón y al cálculo" (468). Y señala el elemento del humanismo martiano - postura intelectual tan vilipendiada por el poder hegemónicoquien entendía que las letras, más que ser vehículo para agenciarse reconocimiento y fama, debían servir para educar y liberar al hombre de las cadenas que lo atan y enmascaran. Martí es un ser tan ardido de amor por el prójimo que en una frase de juventud, que ya contiene la visión ética que guiará su vida dice: "Mi sangre por la sangre de los demás" (XXI, 18). Y ese humanismo -que valoro al final de mi disertación- 
abarca "un repertorio de temas que competen "al hombre antiguo", al hombre religioso, heroico, puro, patriarcal, incorruptible" (469). Todas estas manifestaciones de su carácter y temperamento son esencias de su ser que moldean su escritura, son la sustancia de su persona ética delineando su escritura. Sirva este pensamiento para corroborarlo: "Es ley maravillosa de la naturaleza que sólo esté completo el que se da" (VIII, 153).

Si vinculamos lo que resumimos en el párrafo anterior -su modo de ser distinto del hombre moderno-, con estas características de hombre antiguo, se va perfilando ante nosotros una personalidad atípica, que no encaja en el perfil de la psicología moderna y que como tal es anacrónica. Porque debemos dejar claro que "el hombre moderno, el norteamericano que emprende y triunfa, es el polo opuesto de este tipo de personalidades" (469), es decir, no hay nada más opuesto a su personalidad que la del manager, o la del empresario. Ahora bien, si Martí tiene una personalidad por antonomasia contra-moderna y si su actuación -que forma una unidad indisoluble con su obra-, comporta una evidente atipicidad en cuanto a los rasgos que lo distinguen psicológicamente, entonces nos asalta la pregunta obvia: ¿cómo entonces puede justificarse la presencia de Martí, -no sólo en el modernismo sino, incluso, en la propia modernidad? Si añadimos los elementos del perfil psicológico de Martí que aquí esbozamos con los que hemos descrito en los capítulos anteriores del Martí que disiente de la modernidad burguesa y la estética, estamos mucho más cerca de ir completando el cuadro que intentamos dar de la verdadera dimensión ética de este extraordinario creador y entender mucho mejor por qué se fuga constantemente de la modernidad hacia la periferia. Sin embargo, aún tendremos tiempo de sumar otros elementos de su personalidad al perfil hasta ahora trazado con la intención de acercarnos lo más posible a 
la órbita ontológica y epistemológica desde donde gira su atipicidad histórica y comprender de donde brota la energía con que descompone y desacredita el entramado discursivo moderno.

En el análisis de las peculiaridades del sujeto Martiano no puede faltar -como sugiere Estrada- el carácter que "es el resultado de la lucha entre el individuo y el medio ambiente", y el suyo "es una obra maestra de sus manos" (473). Esta afirmación nos lleva de nuevo a la frase de Martí ya citada que dice: "Yo nací de mí mismo, y de mí mismo brotó a mis ojos, que lo calentaban como soles, el árbol del mundo" (XXI, 167). Con esta frase deja claro que "es una semilla lo único que recibe para formarse, la verdad de que el emblema de su poderoso, perseverante ego es el árbol" (473). Aquí vuelve a aparecer la imagen del árbol que antes citamos en Julio Ramos. Llama la atención que en el Libro de Chilam Balam de Chumayel, de los Mayas también encontremos la metáfora del árbol integrada a su cosmovisión y a las esencias de la vida de su civilización. En el "Libro de los Antiguos Dioses" se nos dice que dentro del Once Ahau Katún el mundo comenzaba a formarse de nuevo y que el cielo se sostenía en sus cuatro puntas por cuatro árboles. Después "se levantó la Gran Madre Ceiba, en medio del recuerdo de la destrucción de la tierra. Y se asentó derecha y alzó su copa, pidiendo hojas eternas. Y con sus ramas y raíces llamaba a su señor" (63-64). ${ }^{14}$ Y más curioso resulta aún el hecho de que el árbol de la Ceiba sea en Cuba -además de fabuloso por su tamaño y anchura- un árbol sagrado, asociado con los ritos inicíacos de las religiones afrocubanas, cuyo contacto con la civilización Maya, que sepamos, $\mathrm{n}$ ha sido establecido.

Cuando Martí comienza su arqueología de la tradición, reinserta en el pergamino occidental, el espacio y el tiempo cosmogónicos, en armonía con los ciclos vitales de la 
naturaleza, "sabiendo que no hay libro que valga lo que una selva nuestra", porque además entiende que "no es lo mismo un árbol que una locomotora". ¿No es acaso esto una indicación de que el árbol -que según él también ama y se sacrifica- es un organismo superior al texto "civilizado" de la tradición logo-céntrica? Este viaje invertido, en la nave del tiempo mitológico, despojado de la erudición y la retórica recalentada de los dómines de la vieja Europa se dirige a desenterrar los mitos que en su "América mestiza" aún tienen páginas espléndidas que descifrar. Los libros americanos no estaban terminados puesto que eran parte de su tiempo primordial arcaico, del poema que hablaba las mil lenguas pintadas en las piedras, en los troncos, en las cumbres. Tanto el Popol Vuh de los Quiché, como el Memorial de Sololá de los Cakchiquel y el Chilam Balam de los Mayas yucatecos eran libros abiertos en una órbita continua del ser hacia la divinidad cósmica. Es decir, como dice Martí para estos pueblos "lo real es simbólico", la mitología está viva, es la forma de pensar el mundo, la vida y el cosmos. Es la manifestación de la belleza, la verdad y la ética. El libro de Occidente, en cambio -lo sabe el poeta cubanose había cerrado hacía dos mil años. Todo estaba dicho allí de manera incontrovertible, el espíritu de la letra estaba muerto, su Dios agonizaba desde el mismo nacimiento.

Estas diferencias entre el libro alfabético y el libro pictórico, entre el libro occidental y el libro americano, nos conducen a señalar un par de criterios que Eric Camays-Freixas incluye en su libro Realismo mágico y primitivismo, como argumentación de lo que antes señalo. En "El lenguaje del "Gran Lengua" dedicado al análisis de la creación de Hombres de maiz, obra maestra de Miguel Ángel Asturias, nos dice que "cuando Ximénez fijó para la posteridad el texto alfabetizado, convirtió al Popol Vuh en libro occidental, en texto muerto" (190). Es decir, al entrar en el logo-centrismo 
occidental el libro se corrompe y se cierra, pierde su capacidad mito-dinámica de interpretación de los símbolos. "Para los indios -dice Asturias- "ser capaz de poner un nombre exacto a algo, significa revelarlo, desnudarlo, despojarlo de su misterio" (190), que es decir, despojarlo de su poesía. "Su esencia de texto abierto, semi-escrito, semioral, semi-pintado, -Flor del Amate- había sido violada y destruida" (190). Pero lo más interesante para Asturias, según testimonia Camayd -también intuición de Martí- es que éste no era, el verdadero Popol Vuh sino, por el contrario, el verdadero texto sagrado era el que seguía vivo en la memoria colectiva de su pueblo, en los mitos y leyendas trasmitidas generación tras generación a través de la oralidad. Hombres de maiz viene a ser -de acuerdo con Camayd-Freixas- una reactualización del Popol Vuh, un intento de devolverle su vitalidad, de abrir sus páginas a nuevas interpretaciones, cosa que, por supuesto, Asturias consigue. Pero ya hacia fines del XIX el poeta cubano tiene, -como el novelista guatemalteco más tarde- la misma certeza de hallar los mitos y leyendas antiguas de Meso-América vivas en la memoria colectiva. El sentido de identificación de Martí con el aborigen, con quien tiene contacto directo en sus viajes por Yucatán y Guatemala, lo hace descubrir la presencia viva en ellos del mito y la poesía.

En el contexto de una civilización logo-céntrica como la occidental y a la luz de la realidad antes expresada, valdría la pena preguntarse si la imposición de la escritura alfabética a las culturas aborígenes no constituye uno de los actos más violentos y desafortunados de la conquista. La escritura pictográfica maya -lo sabemos hoy-era una escritura simbólica saturada de poesía y vitalidad. En tal sentido era una escritura superior a la alfabética pues al tener que interpretar los signos vivos se produce un constante estímulo y ejercicio de la memoria, mientras que aquélla se convierte en 
suplemento de la memoria a la que limita ya que lo que se lee es un signo cerrado, muerto. La mejor respuesta a mi interrogante la encuentro, de cierta forma, en $L a$ diseminación de Derrida. Aunque no es mi intención extenderme demasiado en el tópico, me permito, sin embargo, citar un fragmento de "El Fármacon" por cuanto argumenta mi idea de que la escritura martiana opera al nivel simbólico, metafórico y analógico; alejado lo más que una escritura moderna puede estarlo de la doxología y aún de la filosofía. En el Fedro Derrida plantea que "el rey desprecia al fármacon de la escritura" porque afecta la memoria y, en consecuencia, el saber. En la respuesta de Zamus se lee:

Y el rey replicó: Incomparable maestro de artes, oh Zeuz, uno es el hombre capaz de dar a luz a la institución de un arte; otro el capaz de apreciar lo que ese arte comporta de prejuicio o de utilidad para los hombres que deberán utilizarlo. Ahora tú, en tu calidad de padre de los caracteres de la escritura, les has, por complacencia hacia ellos, atribuido todo lo contrario de sus verdaderos efectos. Pues este conocimiento tendrá como resultado, en los que lo hayan adquirido, en volver olvidadizas a sus almas, pues dejarán de ejercitar su memoria: confiando en efecto en lo escrito, será desde fuera, gracias a huellas exteriores, y no desde el interior, gracias a ellos mismos, como se acordarán de las cosas... En cuanto a la instrucción (Sofias de), es la apariencia (doxan) lo que tú procuras a tus discípulos, y no en absoluto la realidad (aleceian): cuando en efecto con tu ayuda rebosen de conocimientos sin haber recibido enseñanza, parecerán buenos para juzgar de mil cosas, y por la mayor parte del tiempo resultarán carentes de todo juicio; y serán además inseportables porque serán apariencias de hombres instruidos (dosofoi) en vez de ser hombres instruidos (anti sófoi). ${ }^{16}$

Uno de los elementos que se señala aquí como desventaja de la escritura es su pérdida de oralidad que se cancela en el signo escrito, -al que Derrida le atribuye una "rigidez cadavérica"- y su abundancia de opinión, que es algo que viene de la exterioridad y por tanto está más cercana al discurso histórico, filosófico; y no de la interioridad, más vinculada al ontos, a la metáfora, al símbolo que contiene en sí una 
dinámica o una vitalidad intrínsecas, lo cual recuerda las palabras de Martí en carta a Enrique José Varona de 1882 a propósito de los poemas de Ismaelillo: "Fue como uan visita de rayos de sol. Mas, ¡ay! Que luego que las vi puestas en papel, vi que la luz era ida" (XX, 299). Es decir Martí parece haber entendido lo que Derrida sugiere en su investigación: que entre la palabra y la escritura media un abismo en que se oscurecen los caminos del corazón con la "diseminación" de las opiniones de los hombres multiplicadas en su cabeza como larvas en un pantano.

La certeza de Martí -ya sea por observación directa o por intuición- lo lleva a indagar sobre los mitos y leyendas aborígenes de Centroamérica. En su constante reescritura de la historia, al texto occidental, contrapone el autóctono. Durante su estancia en Guatemala escribe su drama Patria y libertad, en el cual el protagonista es el valeroso indio Martino, quien encabeza la rebeldía que expulsa a los tiranos. Libre como el quetzal, se casa con Caona y juntos van a procrear la América nueva: "Ya veo el porvenir que se agiganta /...Y patria y libertad honren valientes / nietos de Cuauhtémoc y Hatuey, con nobles bríos" (VII, 151). No tiene reparos en descalificar todos los atributos del conquistador, o descabezar sus ídolos. Llama a la corona cosa de comedia, a la ciencia mentirosa, y a la religión falsa "Que hoy el catolicismo, padre Antonio, / del cristianismo es muerte y deshonra" (VII, 148). Ni la casa de Dios, ni la casa de justicia, ni la mansión de Doña Casta son los símbolos para construir una patria libre, sino las que surgen de los elementos naturales: "!la libertad impere en mis montañas... / Y la proclaman con sus murmuríos, / las aguas cristalinas de mis fuentes... / y las ondas sonoras de mis ríos" (VII, 151; énfasis míos). Y para reiterar una vez más la unidad de su pensamiento y como la reescritura que hace del texto occidental no obedece a un rapto ocasional, sino a una labor 
arqueológica consciente, iguala -otras veces la autóctona es superior-ambas tradiciones. En "Autores americanos aborígenes dice, refiriéndose a la literatura: ¡Qué augusta la Ilíada de Grecia! ¿Qué brillante la Ilíada indígena! Las lágrimas de Homero son de oro; copas de palmas, pobladas de colibríes, son las estrofas indias" (VIII, 337). Es decir, como señalamos antes, el insufla vida natural en todo aquello que ha sido profanado por el cogito racional, devuelve a la naturaleza, lo que ha sido "civilizado" y maniatado por "el rey amarillo" de que habla a su hijo en Ismaelillo.

A Martí le corresponde el mérito de ser el primer intelectual de la América hispana en producir una heterogeneidad discursiva periférica opuesta al universalismo occidental. En ésta entran el indio, el negro y el mestizo a fundirse como en una fragua. Todas las voces preteridas por el colonialismo encuentran un registro, una representación de igualdad y una jerarquización de sus saberes en su arqueología de la tradición. Pero lo realmente novedoso de Martí, con lo cual produce, inequívocamente, una revolución epistémica dentro de la escritura moderna, es la inserción en su cosmovisión de elementos provenientes de la simbología y la visión cosmogónica aborigen de América. Ese giro, de un absoluto e incontestable americanismo de raíz, no sólo produce una hibridez, sino además una transustanciación porque el se inserta -siendo un Occidental por herencia biológica- en la raza autóctona y dice que por su sangre corre sangre aborigen. Esta reconstitución ontológica a partir de la visión indígena del mundo y de la realidad, sin dejar de ser excepcional para un pensador moderno, es uno de los giros más audaces y extraordinarios de este antillano que no deja de sorprendernos con su intrepidez y heroísmo en el acto de su pensar. Su expresión americanista, su penetración del substrato aborigen hasta donde le permitió su época y su lectura de los rasgos 
distintivos y esenciales del texto de la tradición se cumple en él en fecha bien temprana de su actuación vital. Así lo describe Jorge Mañach en su biografia del poeta cubano:

Su destino ha operado con una precisión y economía geométricas. Le ha llevado a conocer tres países del continente hispánico: uno al Norte, otro al Centro, otro al Sur... A lo largo de esa triple experiencia, su sentido de la realidad americana se ha ido redondeando. México le inicio en el sentimiento de la fraternidad continental. Guatemala le enseñó los valores primitivos: la tradición, el paisaje, el hombre natural. En Venezuela, con el contraste de su pasado y de su presente, ha encontrado, al fin, toda la dimensión trágica de América. (146)

Este viaje ontológico martiano le permite absorber los elementos fundamentales de la cultura y la tradición de estos tres importantes países, pero, a la vez, chocar con sus estructuras de poder. Martí, cuyos principios éticos, al igual que en los estoicos, no son negociables, ni crea en el relativismo, no le queda otra alternativa que abandonar estos países. Pero su amor por ellos, por sus tradiciones y su pasado heroico no disminuyen un ápice. Cuando sale de Venezuela, -último lugar de su periplo americano-, se establece en Nueva York, donde reside por los últimos quince años de su vida hasta que emprende el viaje definitivo de regreso a su Itaca antillana, donde completa su imagen heroica. Los años neoyorquinos son testigos del despliegue, página tras página, en un febril y solitario laboreo, el doble discurso martiano, quizás el fragmento más extenso de toda su escritura. Por un lado abre el archivo de la tradición e instaura su discurso de la alteridad, a contracorriente del discurso moderno. Por el otro, instaura su discurso anticolonial y antiimperialista contra los centros de poder hegemónico en ambos lados del Atlántico, al tiempo que nos deja con su premonición del capitalismo global. El uno es la antítesis del otro. La síntesis la realiza con su escritura ética en la que el causalismo y la racionalidad 
ceden a la armonía y el equilibrio de todos los elementos de la realidad y la unificación del saber, más allá de las totalizaciones discursivas de Occidente. Veamos la estrategia discursiva que emprende Martí con el objetivo de reinsertar el archivo de la tradición y echar por tierra las fabricaciones del euro-centrismo universalista, difundido a través de sus seudo-teorías científicas e intencionalmente falaces. La misión de Martí estará dirigida a deconstruir y desacreditar la falsedad de tales especulaciones acerca del hombre natural de América, de su naturaleza, de su historia, de su inteligencia, de su belleza, de su grandeza. Su misión va dirigida a demostrar que las civilizaciones precolombinas no habían roto la unidad y el equilibrio entre su mundo objetivo y subjetivo y que en consecuencia no era un mundo fragmentado, como la Europa que lo colonizó

\section{El archivo de la tradición.}

La admiración y fascinación de Martí por la arqueología comienza en su primer destierro a España siendo estudiante de filosofía y letras. La extrañeza que comienza a sentir con relación a su circunstancia vital, que presiente desde su temprana adolescencia, lo hacen volver la mirada al pasado en busca de un paisaje subjetivo menos problemático y caótico que el del mundo colonial que le toca vivir. Esta búsqueda espiritual lo lleva a explorar varias tradiciones que se integran posteriormente en su humanismo eticista. $\mathrm{Su}$ natural inquietud por el saber antiguo lo inclinan a leer todo lo que se publica en torno a esta ciencia, interesándose en particular por las excavaciones arqueológicas que se llevan a cabo alrededor del mundo. Es conocido por testimonio de Fermín Valdés Domínguez 
que Martí hizo estudios arqueológicos en el sur de España y Francia, aunque poco se sabe al respecto. Cuando regresa a América da curso a esa pasión en México, Guatemala y Venezuela. En "Antigüedades mexicanas" dice que el Yucatán es muy rico en ruinas y que se ha descubierto una piedra con jeroglíficos que indican que "los hombres acaso conocían ya el modo de usar la electricidad para cruzar mensajes; dos figuras de iguales arreos y apariencia, háblanse en una piedra de Chichén, a poca distancia, más no con inscripciones en figuras sino con rayos, que salen de los labios de ambos" (VIII, 327). Comenta igualmente sobre la reunión de la Asociación Británica a celebrarse en Montreal en 1884 y que tiene una sección dedicada a la antropología donde se tratarán solamente asuntos americanos y elogia a quienes en el continente se han dedicado al estudio de las civilizaciones aborígenes. Es igualmente conocido que cuando se descubre una estatua de Chac Mool en la selva de Yucatán -que curiosamente tenía la cara vuelta al Oriente y la posición recogida del niño en el claustro materno-Martí hace un croquis de la misma en forma de autorretrato. De modo que el acercamiento martiano a la arqueología o la antropología no es efecto de moda o de la curiosidad ocasional del esnobista, sino que está intrínsecamente vinculado a su discurso anti-hegemónico.

Para concluir la caracterización de la personalidad primordial de Martí que comenzamos en al apartado anterior citemos un pensamiento que lo resume. Ezequiel Martínez Estrada menciona que en los "hombres superiores [...] o videntes [...] esos ideales [...] de Libertad, Justicia, Dignidad, Amor, Heroísmo, alcanzan la categoría de instintos irracionales en su esencia que impregnan los actos todos, la conducta : $y^{\prime}$ la doctrina, la razón de vivir y el deber de cumplir el destino" (478). Es decir, esos ideales desafian el discurso del poder y "ni nacen ni se mantienen en la esfera de la razón, de la 
conciencia luminosa, del super-ego, sino en la raíz fisiológica del inconsciente colectivo e intemporal" (478). Luego añade que de este modo"son los antepasados los que ordenan qué ha de hacer su último descendiente" (478). Más adelante habla del inconsciente colectivo y menciona una zona psíquica en la cual conviven todos los seres vivos, tanto los superiores como los inferiores y que éstos revelan un parentesco y hermandad con los humanos que se ha ido revelando mejor después de los trabajos de Fraser, Freud y Jung y yo añadiría a Eliade, Cambell y Lévi-Strauss. Ese parentesco -dice Estrada- es "lo que establece esa participación de una paideuma o un Nous universal, que Schopenhauer concebía como la voluntad" (479). Por eso, no sólo su escritura ética es un paradigma, lo es también su personalidad ética. Son las dos caras de la misma moneda.

En "El hombre antiguo de América y sus artes primitivas" la primera frase de Martí que llama la atención -pertenece a lo que llamo sus fragmentos hipertélicos- es una en que predice los arquetipos del inconsciente de Jung ${ }^{17}$ : "En el espíritu del hombre están, en el espíritu de cada hombre, todas las edades de la naturaleza" (VIII, 333). Su importancia no está sólo en que antecede corrientes de pensamiento posteriores, sino porque además toca uno de los tópicos claves de la realidad de su continente: la relación íntima del hombre americano con su naturaleza. Esa relación cordial ha sido reflejada por la literatura hispanoamericana en la que se puede trazar un puente que va desde los textos aborígenes, pasando por el Inca Garcilaso y Sor Juana Inés de la Cruz, hasta llegar al propio Martí, Vallejo, Neruda, Asturias, Carpentier, Rulfo, García Márquez y tantos otros, y un caso muy sui géneris como lo es el del peruano José María.Arguedas. Es decir, más allá de la imposición de las culturas metropolitanas en el cuerpo americano, en su literatura - expresión esencial de una cultura- ha seguido latente ese enlace íntimo con 
la naturaleza. Esta relación ha sido tan intensa, que no sólo crea la famosa polémica "Civilización vs. Barbarie" que ocupa gran parte del debate político-cultural de siglo XIX americano, sino que le hace afirmar a Fina García Marruz que para el hombre americano, los 'principios morales' tienen que hallar su comprobación, su encarnación, en el orden natural... El americano necesita descubrir una ética en la naturaleza que legitime su búsqueda histórica" (31). ${ }^{18}$ En el hombre americano las edades de la naturaleza de que habla Martí están mucho menos reprimidas que en el hombre blanco de la civilización europea. La resistencia del continente hispano a los modelos progresistas y teleológicos de la modernidad euro-norteamericana se da, o es expresión, precisamente, de los niveles de esos arquetipos del inconsciente. Esta sincronía del pensamiento martiano con el de Jung -que tengamos noticia- no ha sido trazada, pero no se da en una sola frase, sino en varios fragmentos de su cosmovisión. Ahora, ¿qué hace que haya entre Martí y el psicoanalista suizo una correlación de ideas? ¿Cómo puede igualmente entenderse la presencia de ideas similares entre la obra de un Mercia Eliade o de un Joseph Campbell en la obra de Martí, siendo todos ellos posteriores a él. Estos tres investigadores confirman, de un modo que no deja de sorprendernos, cuan profundo había penetrado Martí en la verdad del mundo puesto que cada uno de ellos representa la cumbre del pensamiento en los campos de investigación a los que dedicaron sus vidas. Estas sincronías merecen, sin lugar a dudas, una extensa investigación, imposible de desarrollar en estas páginas.

No obstante, para cerrar este fragmento comparemos un pensamiento de Martí con uno de Jung como testimonio de lo que afirmamos. El cubano dice que "todo lo real es simbólico" y el suizo que "en el caso del trabajo simbólico, debemos recordar el 
dictum de Gerhard Haupmann: 'La poesía evoca con las palabras la resonancia del mundo primordial'. La pregunta que debemos entonces hacernos es: ‘¿Qué imagen primordial subyace detrás de la imagen artística?"19. Después añade algo que por la semejanza que guarda con la palabra martiana parecería una explicación de alguno de sus textos o una extensión de algunas de las interpretaciones que sobre su escritura han hecho otros críticos:

El impacto de un arquetipo, ya sea en la forma de una experiencia personal o a través de la palabra, nos conmueve porque resume una voz que es más fuerte que la nuestra. Quien quiera que hable en imágenes primordiales habla con mil voces, embelesa y seduce, al tiempo que saca la idea que busca expresar fuera de lo ocasional y transitorio y la coloca dentro del reino de lo eterno. Él transfiere nuestro destino personal al destino de la humano y evoca en nosotros esas fuerzas benéficas que una y otra vez han permitido a la humanidad sobrevivir la noche eterna.

Ese es el secreto del gran arte y su efecto en nosotros. El proceso creativo hasta donde podemos seguirlo, consiste en la activación de una imagen arquetípica y la conversión de esa imagen en una obra de arte acabada. Al darle forma el artista la traduce a la lengua del presente y hace posible que podamos volver a los más profundos manantiales de la vida [...] El anhelo insatisfecho del artista retrocede a la imagen primordial del inconsciente, mejor preparada para compensar la insuficiencia y unilateralidad del presente. $^{20}$

Las ideas de Jung podrían ser un colofón de las de Vitier y de otros críticos cuando hablan de la futuridad de Martí, de cómo su escritura es un constante trascender el presente y fraguar el futuro. Al llegar a comprender que "todo lo real es símbólico" impregnó su poesía y su prosa poemática de símbolos y analogías que forman parte de ese inconsciente colectivo o de esas "edades de la naturaleza" de que él nos habla. De ahí que no sea nada extraño que Miguel de Unamuno - poeta y pensador como el propio Martí- encontrara en su escritura imágenes de naturaleza protoplasmática, que no son 
otra cosa que los signos primordiales que atraviesan los manantiales profundos del ser humano y que la poesía sabe captar en metáforas como el lente de una cámara capta las imágenes del mundo físico.

El archivo de la tradición es, como hemos afirmado, uno de los fragmentos contra-modernos más importantes de su escritura. Lo primero que hace Martí es cuestionar el historicismo teleológico en su linealidad: "La edad de piedra subsiste en medio de la edad moderna. No hay leyes de la vida adscritas a una época especial de la historia humana. Dondequiera que nace un pueblo nuevo, allí renace con él, -nueva, grandiosa y feral,- la vida" (VIII, 331). Es decir, la modernidad es un fenómeno social, un proceso típico de una cultura que antes tuvo otra edad -la de piedra, por ejemplo- y las que atraviesan hoy por la de piedra, mañana alcanzarán otra edad. En otras palabras, todas las sociedades cumplen diferentes ciclos y éstos no son privativos de ninguna sociedad en particular. Esta reflexión es completada con esta otra:

No más que pueblos en cierne, -que ni todos los pueblos se cuajan de un mismo modo, ni bastan unos cuantos siglos para cuajar un pueblo, -no más que pueblos en bulbo eran aquellos en que con maña sutil de viejos vividores se entró el conquistador valiente, y descargó su ponderosa cerrajería, lo cual fue una desdicha histórica y un crimen natural. El tallo esbelto debió dejarse erguido, para que pudiera verse luego en toda su hermosura la obra entera y florecida de la naturaleza. ¡Robaron los conquistadores una página al universo! (VIII, 335).

Para empezar diremos que aquí Martí echa por tierra cualquier argumento que pueda justificar la conquista porque fue una "desdicha histórica y un crimen natural". Desdicha histórica porque el resto del mundo -incluido el Occidente- perdió la oportunidad de ver en la realidad su propio pasado y hubiera tenido un modelo para 
corregir sus propios excesos y sus falacias racionales. Fue una desgracia histórica que quienes vinieron al des(encuentro) de las culturas aborígenes -que no descubrierontraian superioridad militar, pero sobre todo, y lo peor, traían un fanatismo y una intolerancia por lo desconocido alimentada en varios siglos de batalla contra el mundo árabe que, a diferencia del ibero, nunca cometió un genocidio con ellos y fue mucho más tolerante religiosa y culturalmente. Después de hacer las precisiones históricas que hace en el fragmento anterior, culmina su pensamiento de esta forma:

Aquellos eran los pueblos que llamaban a la Vía Láctea "el camino de las almas"; para quienes el Universo estaba lleno del grande Espíritu, en cuyo seno se encerraba toda luz, del arco iris (llamaban al arco iris "penacho de Dios") coronado como de un penacho, rodeado de colosales faisanes, de los cometas orgullosos que paseaban por entre el sol dormido (que era como llamaban a la luna) y la montaña inmóvil el espíritu de las estrellas; los pueblos eran que no imaginaron como los hebreos a la mujer hecha de un hueso y al hombre hecho de lodo; isino a ambos nacidos a un tiempo de la semilla de la palma. (335, paréntesis míos)

En esta última imagen del hombre y la mujer americanos nacidos de una sola semilla de palma es una referencia a la idea martiana del Gran Semí con que cierra su ensayo "Nuestra América", divinidad que condensa las creencias de los aborígenes del Amazonas. Para él esta idea del origen tiene más belleza poética puesto que está vinculada a la naturaleza y hay en ella más sentido de justicia e igualdad: ambos vienen al unísono de la misma fuente. Nótese igualmente el sentido estético de las analogías martianas, muchas de ellas relacionadas con la simbología de los pueblos mayas. Es decir, el hombre americano revestía sus cosmogonías de elementos mito-poéticos, metafóricos, analógicos. En tal sentido nos dice Cintio Vitier en su ensayo "Una fuente venezolana de José Martí", que los aborígenes hacían lo mismo que el poeta con los datos 
de la realidad: "recrearlos, transfigurarlos, descubrirle la sustancia simbólica que los convierte en palabras de un nuevo lenguaje" $(266-67) .^{21}$ Por consiguiente, es de todo punto natural "que lo atrajera tanto el lenguaje mítico y poético de los indígenas, lleno de conjeturas espirituales, de resumidoras metáforas y de intuiciones pre-científicas" (267). Refiriéndose Martí a los textos indígenas que se salvaron de las hogueras "de obispos Landas y Zumarragas" dice que en ellos la frase india es elegante como la palma, brilla como las frondas de sus montes y está matizada de los mil colores que su paisaje le obsequia.

Lo negará quien no haya leído un cuento de batalla o un título de propiedad de los indios guatemaltecos. El Mahabarata es más sentencioso; el Schahnameh, más grave; las profecías de Chilam Balam más reposadas y profundas; las odas de Netzahualcóyotl mexicano, más sublimes; más apasionados los dramas peruanos: el Apu Ollantay, el Usca Pankar acaso; resplandecen las tradiciones de Tingal, como túnica cuajada de diamantes... (VIII, 335)

Ensalza la literatura producida por las civilizaciones americanas autóctonas, sobre todo resaltando los elementos naturales que entran a formar parte de las frases en sus textos, tanto de carácter religioso, como de carácter cívico. Según entiende la literatura es reflejo de "la Naturaleza que nutre el espíritu que anima al pueblo que la crea" y, entonces, “¿cómo pudiera ser que, contra ley universal, no tuviese la literatura indígena las condiciones de esbeltez, armonía y color de la naturaleza americana?" (336). Martí testimonia que la admiración por los textos indígenas no es sólo de los hispanoamericanos, pues se debe comentar un libro escrito por Daniel.S. Brinton, un norteamericano, que es hoy uno de los mejores americanistas que admira "cuan amplio, apropiado y flexible era el vocabulario de los aborígenes" (337) y señala en ellos una 
facultad literaria poderosa. A continuación vuelve a su contra-discurso cultural al comparar la escritura aborigen con la de los europeos para que no quede duda de que la expresión americana estaba al nivel y, en ocasiones por encima, de la de los clásicos antiguos, padres espirituales de la Europa moderna que ellos niegan. "Vese en sus ruinas, como en sus manuscritos, su gusto por la simetría y el ornamento. Sus Atreos y sus Niestes tuvieron los griegos, y voluble Europa; también los indios los tuvieron" (337), y si se valora lo que se ha podido interpretar de sus escasas páginas y signos "con más lujo y pasión están contadas en sus pergaminos y sus piedras que las de Atridas y Pelópidas en el glorioso romance griego" (337). O sea, que si los griegos tuvieron su Ilíada y sus romances, los aborígenes americanos los tuvieron también. En términos de inteligencia y creatividad artística, no hay ninguna inferioridad de la raza indigena con respecto a la europea. Por el contrario, los habitantes oriundos de América, en muchos sentidos, aventajan a la raza conquistadora.

En "Autores mexicanos aborígenes", texto de Martí que he venido citando hay un fragmento que reúne varios conceptos centrales de su discurso de la autoctonía. Comienza Martí elogiando a Brinton porque es capaz de ver la grandeza de América y ama a los indios como a lirio roto y porque ha leído lo que los éstos escribieron en sus lengua patrias. De modo que -y esa es la primera sutileza- al margen de la diversidad de lenguas habladas en el continente a la llegada de los conquistadores, eran la expresión de un espacio y una esencia muy especial que se llama "patria", el espacio de la intensidad, vinculado al concepto que de él elabora más tarde Lezama. Si evaluamos la idea que de patria tiene Martí podremos entender el significado que tiene la frase: tenían su lengua, tenían su patria -su espacio cultural-, tenían su literatura, tenían sus dioses en el seno de 
la fertilidad de la naturaleza, por tanto su expresión artística era el resultado de la comunión del alma aborigen con su cosmogonía, de donde obtenía sus metáforas y símbolos porque para ellos todo era uno, fuente última de inspiración y trascendencia, madre de la vida. Pues bien, dice Martí:

¡Qué instituciones tenía Tlaxcala! ¿Qué bravos, Mayapán! Teotitlán, ¿qué escuelas! Copán, iqué circo! México, iqué talleres, plazas y acueductos! Zempoala, iqué templos! Los Andes, iqué calzadas! ¿Qué importa que vengamos de padres de sangre mora y cutis blanco? El espíritu de los hombres flota sobre la tierra en que vivieron, y se le respira. jSe viene de padres de Valencia y madres de Canarias, y se siente correr por las venas la sangre enardecida de Tamanaco y Paramaconi, y se ve como propia la que vertieron por las breñas del cerro del Calvario, pecho a pecho con los gonzalos de férrea armadura, los desnudos y heroicos caracas! (VIII, $336)^{22}$

Después de enumerar todas las grandezas que el norteamericano ha podido constatar en su estudio de las civilizaciones aborígenes de América, escribe un pensamiento que contiene uno de los conceptos más radicales de su discurso de la tradición y con el cual subvierte las ideas racistas seudo-científicas de los "pensadores de lámparas" europeos. Él es blanco, de padres europeos, pero por su sangre corre sangre de héroes indígenas, hermosos ejemplares de la raza aborigen que los compatriotas de sus padres asesinaron de manera brutal. De los héroes caracas tiene noticias a través del brillante trabajo historiográfico desarrollado por Arístides Rojas ${ }^{23}$ a quien conoce en la capital venezolana en 1881. Es decir, por un proceso de ósmosis o de contagio respiratorio, "El espíritu de los hombres flota sobre la tierra en que vivieron, y se le respira", o por pasión amorosa, él se siente más aborigen que europeo pues sus órganos vitales -el corazón, la sangre que lo hace latir y los ríos profundos de su ser- piensan y 
sienten como un aborigen. En otras palabras, no necesita -como Darío- racionalizar su filiación racial, sino más bien irracionalizarla, llevarla al límite de la interpretación con el magro discurso cartesiano. $\mathrm{O}$, para ser más exactos y hacerle realmente justicia, no pertenece a ninguna raza, no tiene más raza que su condición humana y por eso puede transfundirse en el otro. Esta operación psicosomática ocurre en él, de la misma manera, con otras razas como la negra y la árabe, que no por coincidencia son las colonizadas de su época y lo siguen siendo de la nuestra, lo cual testimonia una vez más que estaba incondicionalmente del lado de los oprimidos. Digamos de paso que esta capacidad sicosomática martiana de transmutación en la alteridad es uno de los rasgos psicológicos más asombrosos de su personalidad y condición rara entre los hombres. Para la mentalidad del hombre moderno, automático, esta trasmutación racial que se da en Martí resulta un concepto límite, más allá de su aprehensión racional. Ese transformarse en el otro es un giro demasiado extraño para su órbita mecánica. El hombre moderno, ya lo hemos dicho, es un ser que ha sido desplazado, por la maquinaria del poder, de los espacios de hermandad, fraternidad, bondad, armonía, equilibrio y amor que se funden en la visión ecuménica de la tradición y del pensamiento americanista martiano. Ese "yo" que se funde en el "nosotros" del hombre natural donde está protegido de otra orfandad es un espacio reprimido y oculto en el subconsciente del hombre tecnológico, pues el poder entiende muy bien que no es posible controlar y someter a un ser unificado y hermanado por lazos de amor en la comunidad que es su patria. Para que se tenga una idea más exacta de cuánto Martí representa psicológicamente un hombre natural y cuan alejado estaba del modelo de hombre racional, veamos otras palabras de Domingo Faustino Sarmiento, -modelo de hombre moderno si los hay-, antítesis de las del cubano 
cuando dice que por sus venas corre sangre indígena. Cuando Sarmiento se interroga sobre los héroes indígenas, comenta Roberto Fernández Retamar- esto es lo que piensa el escritor argentino;

Para nosotros Colocolo, Lautaro y Caupolicán, no obstante los ropajes nobles y civilizados [con] que los revistiera Ercilla, no son más que unos indios asquerosos, a quienes habríamos hecho colgar ahora, si reapareciesen en una guerra de los araucanos contra Chile, que nada tiene que ver con esa canalla. ${ }^{24}$

Los araucanos fueron, entre las tribus y pueblos aborígenes del continente, quienes mayor resistencia hicieron a los españoles en su empresa de conquista. Defendieron con tal valentía y arrojo su territorio que fueron capaces de suscitar la inspiración de Alonso de Ercilla, quien escribe una epopeya en la que resalta la heroicidad de este pueblo. Por eso las palabras de Sarmiento son aún más cáusticas e incomprensibles y nos hacen pensar que su sentido histórico estaba enfermizamente torcido. Para él los héroes araucas son unos "indios asquerosos" porque hicieron lo que todo hombre honrado hace cuando le invaden la patria, que es defenderla. En realidad estas palabras no merecen comentario, pero sirven al lector para juzgar cuan diametralmente opuestas eran las visiones de estos dos intelectuales del siglo XIX americano y cuan contrario era el viaje que cada uno había emprendido. Sirve también para ilustrar como Martí representa el pensamiento americano autóctono, mientras Sarmiento el pensamiento euro-céntrico universalista burgués de los conquistadores. Martí culmina con estas reflexiones:

Bueno es abrir canales, sembrar escuelas, crear líneas de vapores, ponerse al nivel del propio tiempo, estar al lado de la vanguardia en la hermosa 
marcha humana; pero es bueno, para no desmayar en ella por falta de espíritu o alarde de espíritu falso, alimentarse, por el recuerdo y la admiración, por el estudio justiciero y la amorosa lástima, de ese ferviente espíritu de la naturaleza en que se nace, crecido y avivado por el de los hombres de toda raza que de ella surgen y en ella se sepultan. Sólo cuando $\underline{\text { son directas, prosperan la política y la literatura. La inteligencia americana }}$ es un penacho indígena. ¿No se ve cómo del mismo golpe que paralizó al indio, se paralizó a América? Y hasta que no se haga andar al indio, no comenzará a andar bien la América. (336-37; énfasis míos)

Lo que desprende del pensamiento martiano -digámoslo a propósito de esta comparación- es un sentido de proyección del avance humano por encima del pragmatismo y el utilitarismo, sin contaminaciones relativistas, con una presencia de la justicia y el amor en lo que juzga, que es lo que convierte su legado americanista en un organismo vivo y actuante en las circunstancias del presente. Si examinamos este fragmento frase por frase lo primero que notaríamos es que las referencias que hace al avance humano no incluyen ninguna de las ideas tópicas del discurso de la modernidad. No menciona ni la palabra "progreso", ni la palabra industria, ni la palabra ferrocarril, ni la palabra mecánica, ni siquiera la palabra desarrollo, tan cara al lenguaje colonial y neocolonial de las Naciones Unidas. Martí habla de "ponerse al nivel del propio tiempo" y "estar al lado de la vanguardia en la hermosa marcha humana" dos conceptos que no son privativos de la modernidad, sino que atraviesan toda la historia del hombre, a despecho de la atomización que la modernidad hace con su deificada idea de "progreso" de los conceptos de avance y crecimiento social y espiritual. En ello se manifiesta otro de los intentos visibles en su obra -ya referido- que es el de descolonizar también el lenguaje.

A este concepto de avance, que es para él "ponerse al nivel del propio tiempo", le suma varias ideas que no aparecen, ni remotamente, en el concepto de modernidad 
occidental. La primera es la del "recuerdo" y la "admiración" de lo pasado de la tradición que sabemos la modernidad burguesa desecha. Lo segundo es "el estudio justiciero y la amorosa lástima". Ni la justicia, y menos aún el amor, han caracterizado al "progreso" occidental. Por el contrario, ha sido una máquina de violaciones, atropellos y genocidios. La lista aquí sería muy extensa y rebasaría los propósitos de este análisis, pero digamos, a modo general que, las revoluciones industriales de occidente -símbolos incontestables del "progreso"- son el resultado de la expropiación de tierras a sus legítimos dueños en las metrópolis y las colonias, el sometimiento a esclavitud a grandes masas de hombres, la explotación en condiciones infrahumanas de las fuerzas productivas en las fábricas, el robo de capitales, el intercambio desigual y los genocidios cometidos en sus empresas imperiales. En pocas palabras, la justicia y la amorosa lástima de que Martí habla Łes decir la equidad- no han sido nunca parte del proyecto desarrollista y progresista de la civilización occidental, mas todo lo contrario, ha sido un proceso de saqueo, ilegalidad, arbitrariedad y constantes violaciones de los derechos elementales del ser humano de todos los pueblos del mal llamado tercer mundo. De modo que hasta aquí el concepto de avance de Martí se nos ha distanciado ya bastante del concepto moderno. Hay en este criterio martiano otra idea de suma importancia y que me interesa destacar por cuanto nos aproxima a una realidad otra, muchas veces difícil de visualizar, sino lo hacemos con su mirada órfica. Los conceptos de "desarrollo" y "progreso" de la modernidad burguesa han sido inscritos con tal fuerza en el consciente colectivo del hombre moderno y contemporáneo que pensar el mundo sin ellos resulta casi una aberración o, -en el mejor de los casos-, un contrasentido. Sin embargo el poeta cubano nos dice en el siglo XIX que lo que se necesita es crecimiento y mejoramiento del espíritu humano y con el 
estudio y trabajo justiciero y amoroso "ponerse al nivel del propio tiempo" y "alimentarse por el recuerdo y la admiración de la naturaleza" que ayuda a sepultar el espíritu falso. O sea, distingue con mucho cuidado ese "progreso" que ha producido las calamidades antes referidas del avance y crecimiento en equilibrio con las fuerzas espirituales del hombre en ejercicio de su legítima libertad y el espíritu de equilibrio y bienestar de la naturaleza. No contra la naturaleza, que es barbarie, sino con la naturaleza que es crecimiento. No en línea recta hacia un futuro cuyo paisaje está contaminado y por tanto no se puede entre tanto desecho, distinguir la luz, sino hacia arriba que es un paisaje imposible de contaminar a pesar de las aventuras fantásticas de los vuelos planetarios.

Para Martí el avance y crecimiento se da con el concurso de todas las razas y todos los pueblos en armonía con la naturaleza y no de unos pocos, en detrimento de la mayoría. La humanidad - uno de sus más anhelados sueños- era una gran familia de pueblos viviendo en paz, concordia y fraternidad. De ahí su concepto estoico de "patria es humanidad". Por eso "sólo cuando son directas, prosperan la política y la literatura”. ¿Ha estado la modernización occidental preocupada con el equilibrio y protección de la naturaleza? Ciertamente no. Por el contrario, esta modernidad y este "progreso" convierten a la naturaleza, después de haberla despojado de todas sus divinidades, en taller. Tanto para Martí, como para los aborígenes americanos, la naturaleza es templo; para la modernidad es taller. No hay dos conceptos más antinómicos en su esencia. ¿Llevó a cabo su proceso modernizador con la unión de todas las razas? Mucho menos. Una de las racionalizaciones más difundidas por el discurso falaz euro-céntrico lo fue la inferioridad racial de los pueblos no europeos. Lo que Martí dice al inicio de este fragmento que es "bueno es abrir canales, sembrar escuelas, abrir líneas de vapores". Es 
muy curioso que los medios de transporte usados por los aborígenes americanos fueran naturales, pero es natural que lo fueran, considerando que para ellos la naturaleza no era taller, sino templo. De modo que nuestro poeta refiere aquí como medio de transporte el agua: canales y vapores, y cuando habla de educar el término que utiliza es sembrar. Si ligamos esto a sus conceptos educacionales referidos a la creación de escuelas agrarias donde se estudien los elementos naturales de los países de su "América mestiza" podremos entender mejor el concepto martiano contra el "progreso" de Occidente. Ese proyecto de desarrollo científico-racional ha generado las más patéticas expectativas y ha fracasado. El presente va aclarando cada vez más el sentido de crisis y decadencia que la modernidad viene imponiendo desde hace más de doscientos años.

Al final del párrafo nos sorprende con otra audacia epistémica: "la inteligencia americana es un penacho indígena". Para el europeo y el norteamericano el indígena es de raza inferior, para Martí es la inteligencia de América y su estancamiento se debe al golpe colonial que lo paralizó, no a su incapacidad para ponerse al nivel de su tiempo. Y que América no andará bien hasta que no se incorpore al indio con su saber y su cultura, con derechos de igualdad, al resto de sus sociedades. La exclusión de la masa indígena de las riquezas que ellos contribuyen a crear en sus sociedades sigue siendo una de las promesas incumplidas por los proyectos desarrollistas de América Latina. La raza indígena sigue sufriendo el desarraigo y la injusticia que les trajo el colonialismo, como sufre el proceso modernizador del continente que lo excluyó y esclavizó, además de introducirle elementos ajenos, inoperantes y contrarios a sus esencias culturales. En los países donde la masa indígena es mayoría el "progreso" y la modernización ofrecen un paisaje de desigualdad, miseria y explotación que, contrario a la verdad, (aún en pleno 
siglo XXI, después de todo el aporte de la teoría y la crítica contemporáneas y de los estudios culturales a la desmitificación de las falacias raciales), el discurso modernizador achaca a la incapacidad de la raza aborigen. En este sentido la premonición de Martí sigue siendo una herida abierta en el cuerpo social de la "América mestiza" y hasta que esa herida no cicatrice no avanzará el continente de manera orgánica y equilibrada a ocupar el lugar que le corresponde en la familia de pueblos libres y prósperos de la humanidad.

\subsection{EI "hombre natural" de América. Primitivismo vs. Modernidad.}

El hombre antiguo de América logra crear civilizaciones de un alto nivel social, económico, cultural, científico y artístico, resultado de su evolución natural y a tenor de sus propias tradiciones. En las áreas periféricas de las tres grandes civilizaciones vivía en comunidades autosuficientes en armonía con la naturaleza. Tal como las civilizaciones antiguas del Oriente no había roto su ciclo cosmogónico y el símbolo seguía estando en su cosmovisión mito-poético. Por tanto la linealidad occidental y la proyección de sus sueños y utopías en un futuro lejano eran ajenas a su mentalidad como igualmente sus visiones escatológicas con las que habían demonizado la muerte. Para él la vida y la muerte constituían esencias de la misma esfera, conectada con la razón cósmica. Es decir, la racionalización de la existencia confinada en metarrelatos jerarquizados por las estructuras del poder constituye un reduccionismo que antagoniza con su comprensión de la naturaleza y de la existencia humana. Se siente parte de un todo que está más allá de su comprensión, pero que sabe armónico y no intenta cambiar. Según Mircea Eliade para 
este ser arcaico "los objetos del mundo exterior, como los actos humanos propiamente dichos, no tienen valor intrínseco autónomo. Un objeto o una acción adquieren un valor $y$, de esta forma llegan a ser reales, porque participan, de una manera u otra, en una realidad que los trasciende" (14). Todo lo que el hombre no es puede resultar incomprensible e invulnerable a la vez. Está fuera del aquí y del ahora, encarna en una eternidad. "Una piedra, entre tantas otras cosas, llega a ser sagrada-y, por tanto, se haya instantáneamente saturada de ser- por el hecho de que su forma acusa una participación en un símbolo determinado, o también porque constituye una hierofanía, posee mana, conmemora un acto mítico" (14). ${ }^{25} \mathrm{Ni}$ el homo-centrismo, ni el logo-centrismo occidental han contaminado su ser.

Para el hombre primitivo de América el tiempo al tener "una dirección cíclica, anula su irreversibilidad. Todo comienza por su principio a cada instante. El pasado no es sino la prefiguración del futuro" $(86)^{26}$. En su mentalidad la obsesión de lo nuevo que contamina el cuerpo de la modernidad es incomprensible pues para él "todo no es más que la repetición de los mismos arquetipos primordiales". Sólo a través de ese ciclismo la realidad se le revela porque encarna en lo arquetípico y, en esencia, conjura la historia o la desdibuja en el rito. Esa visión es una de las diferencias esenciales del "hombre natural", respecto del hombre moderno, caído.

...durante un lapso bastante extenso la humanidad se opuso por todos los medios a la "historia". ¿Podemos sacar en conclusión de todo eso que durante ese período la humanidad permaneció en la naturaleza, sin apartarse de ella? "Sólo el animal es verdaderamente inocente", escribió Hegel al principio de sus Lecciones sobre la filosofia de la historia. Los primitivos no siempre se sentían inocentes, pero intentaban volverlo a ser por la confesión periódica de sus faltas. ¿Es lícito ver, en esta tendencia de la purificación, la nostalgia del paraíso perdido de la animalidad? ¿O es 
más bien menester percibir en ese deseo de no tener "memoria", de no registrar el tiempo y de contentarse sólo con soportarlo como una dimensión de la existencia -pero sin "interiorizarlo", sin transformarlo en conciencia-, la sed del primitivo por lo "óntico", su voluntad de ser, como son los seres arquetípicos, cuyas acciones reproduce sin cesar. (87)

Esa voluntad del ser del hombre primitivo lo mantenía en perenne contacto con su dimensión existencial y con la dimensión sagrada de su mundo físico. Ambas constituían una unidad indisoluble y eterna. Esa conexión -que en las sociedades aborígenes de América está suficientemente documentada- al tiempo que los protegía de los fantasmas de la muerte, les permitía el contacto directo con las divinidades. Por eso Martí insiste en que la justicia y el poema están en la naturaleza. Si ésta les daba el pan, el techo, la protección y albergaba sus dioses, y si además, de ella obtenían sus arquetipos, sus expresiones espirituales, entonces estaba claro el poeta cubano al intuir esa unidad: “¡Arpa soy, salterio soy / donde vibra el Universo: / Vengo del sol y al sol voy: / Soy el amor: soy el verso!" $(254)^{27}$. Esa esfera contiene al hombre y a la divinidad y por eso la comunicación de las dos dimensiones esenciales del ser no se rompe. "In illo tempore los dioses descendían a la tierra y se mezclaban con los humanos; por su parte, los hombres podían subir fácilmente al cielo" (87) por "el camino de las almas" que así llamaban los Mayas a la Vía Láctea, como dejamos dicho. Cuando sucede la primera escisión, cuando se produce la primera grieta en el acto ritual, los dioses se retiran al cielo y se pierde la comunicación entre ambos. El hombre pierde la inmortalidad y en adelante tendrá que trabajar, que darle vueltas a la noria, con la cadena al cuello o el grillete a los pies. Si juntamos estos elementos de la mentalidad arcaica, y lo que explicamos del "arcaico profundo" que según Jorge Mañach es Martí, se puede entender mejor lo que he afirmado 
de que él reencarna en esa mentalidad primitiva, aborigen, no desde un discurso, sino desde el ser del otro, desde la alteridad sagrada del otro hombre. Penetrar el magma de esa ontología le permitió entender "el comportamiento, incluso el más extravagante, del "mundo primitivo"; porque en efecto, este comportamiento responde a un esfuerzo desesperado por no perder el contacto con el ser" (88). Si recordamos lo que Martí analiza en el Prólogo al Poema del Niágara referido a la reconquista del ser como primer deber del hombre, como urgencia insoslayable, tendremos los elementos necesarios para valorar, justamente, hasta qué punto es válida la tesis del arcaico profundo en Martí. Cuando Martí abre su discurso de la otredad y destapa las esencias híbridas de la "América mestiza" viene ya un hombre dueño absoluto de su ser, reconquistado para la libertad y con pleno dominio de todas sus facultades físicas y espirituales.

Cuando mencionamos anteriormente la agonía que el "hombre natural" de América debió haber sentido ante la humillación y la sumisión de su ser a un tipo de hombre que, como el moderno, sabía inferior y degradado no pensábamos en El mito del eterno retorno, ni en su autor, sino pensábamos en Martí y sus expresiones de odio a los rifles que los mataron, las hogueras que los quemaron y los perros que los destrozaron. Sin embargo, vale la pena, por su correlación, testimoniar estas palabras de Mircea Eliade donde hace referencia a una idea similar, es decir, a la desgracia que han tenido que sufrir algunos pueblos por encontrarse en el camino de la historia occidental, de su modernidad y de su empresa (des)civilizadora. El etnólogo se pregunta "cómo pueden soportarse, y justificarse, los dolores y la desaparición de tantos pueblos que sufren y desaparecen por el simple motivo de hallarse en el camino de la historia, de ser vecinos de imperios en estado de expansión permanente" (138). Lo ejemplifica con un grupo de países de la 
Europa del este, que de cierta forma han padecido la misma suerte que el conglomerado de pueblos que conforman los continentes de Asia, África y América latina, naciones que fueron colonizadas por Occidente.

¿...cómo justificar [...] el hecho de que el sudeste de Europa haya debido sufrir durante siglos $-\mathrm{y}$ por consiguiente renunciar a toda veleidad de existencia histórica superior, a la creación espiritual en el plano universalpor la sola razón de hallarse en la ruta de los invasores asiáticos y de ser luego vecino del imperio otomano? Y en nuestros días, cuando la presión histórica no permite ya ninguna evasión, ¿cómo podrá el hombre soportar las catástrofes y los horrores de la historia -desde las deportaciones y los asesinatos colectivos hasta el bombardeo atómico- si, por otro lado, no se presiente ningún signo, ninguna intención transhistórica, si tales horrores son sólo el juego ciego de fuerzas económicas, sociales o políticas o, aún peor, el resultado de las "libertades" que una minoría se toma y ejerce directamente en la escena de la historia universal? (138-39)

Después de analizar los factores que conforman el universo, tanto del hombre natural como del moderno con el objetivo de entender mejor la dimensión arcaica del pensamiento martiano, aún podría asaltarnos la pregunta de por qué hay ese rechazo casi de horror en el hombre primitivo hacia la historia. Para empezar hay que decir que en ese tejido de hechos y acontecimientos lineales que llamamos historia se produce una tendencia a la desacralización del mundo físico a partir del extrañamiento que asume el hombre "civilizado" con relación a la naturaleza, a las divinidades agrarias, al mito; de la distancia que establece entre él y el resto de los seres vivos que considera inferiores, de su carácter autónomo y jerárquico que, a fin de cuentas, produce el homo-centrismo del "ser histórico". Todos estos factores producen una descentralización y un desequilibrio de su psiquis, una orfandad del "yo" que, en última instancia, conduce a la psicosis y la alienación. El hombre primitivo sabe que dentro de su cosmogonía y de la tribu está 
protegido en una familia que es engendradora de hermandad y fraternidad. A pesar del bombardeo inmisericorde de la modernidad progresista (en violenta fuga hacia un futuro que no llega, divorciado de lo real), en la mentalidad humana el tiempo cíclico nunca ha desaparecido del todo. En la conciencia crítica moderna y en sus manifestaciones artísticas -como comenta Eliade- aparece el rechazo hacia su historicismo teleológico y un espíritu de reactivación del tiempo cósmico, cíclico, natural de la vida, como son los casos de Whitman, Eliot, Joy, Kafka, y otros.

Martí, como dejamos explicado en su contra-discurso de la modernidad estética saca la actividad creativa de la historia y la coloca en la naturaleza. Ahora bien, cómo valorar en su justa medida la idea de que "el poema está en la naturaleza", entendiéndose como tal lo poético que sobrepasa la marca genérica. La audacia está en llegar a comprender en la época de apoteosis del cientificismo, el historicismo y el utilitarismo a ultranza que la poesía estaba en el mito y no en el acontecimiento, ni en el cambio; en lo eterno, y no en lo falible, cambiable o manufacturable como proceso. En otras palabras la poesía -lo poético- no está en la mecánica, que es la aniquilación sorda de la naturaleza, sino en la música del espacio que es ese poeta de mil lenguas que refiere Jung. Y esta afirmación cierra la posibilidad de convertir al arte en mercancía. Ahí radica la belleza y a la vez el sentido ético de esta frase, que pudiera parecer inocente o forzada. Pero eso no sería martiano.

Si la historia en realidad es, cada vez con más certidumbre, el proceso de imposición del poder hegemónico de una minoría sobre las masas, el ser humano no tiene cómo salir de la historia que le imponen, está obligado a vivir esa historia de crisis y decadencia que lo aleja angustiosamente de su condición esencial humana. La libertad 
que se le ofrece como pasaporte y como sucedáneo para ese viaje es una mascarada, una ironía mordaz, un viaje sin retorno. Las únicas opciones que le quedan son "oponerse a la historia que hace esa limitada minoría (y en ese caso tiene la libertad de elegir entre el suicidio y el destierro) [o] refugiarse en una existencia sub-humana o en la evasión" (144). Martí, sin embargo, al superar el marco histórico de la modernidad decadente, escapa del nihilismo, el pesimismo y el evasionismo del arte de su época. En él se revela el hombre natural, tradicional, arcaico, que es la absoluta antítesis del hombre de la modernidad y diríamos para ponerlo de una forma gráfica, el tercer escalón en su ascenso hacia su orbe ético que clausura la modernidad. El "hombre natural" martiano deja en la modernidad una dimensión histórica sumamente precaria, un cuerpo casi vacío que agoniza. Lo que va quedando de ésta son retazos problemáticos, cada vez más discordes con su ser ético fundamental cuya dignidad sobrepasa la marca del pragmatismo y el individualismo de los ruines tiempos que vive. Cuando entremos de lleno en su escritura ética veremos como ese hombre moderno de Martí da sus últimos estertores y pasa, literalmente a otra dimensión.

\section{Contra-discurso de las seudo teorías racistas europeas}

Hay en el hombre ético martiano -vistas las causas y su racionalización- una convicción de que no hay nada superior del hombre europeo respecto del americano o ninguna otra raza. Va incluso más lejos al argumentar que el americano aborigen es superior en ciertos aspectos, algo muy revolucionario en su momento puesto que nadie concebía en esa época que, teniendo que defender la acusación de inferioridad de que se 
era víctima en América por "científicos reputados" que contaban con el aparato propagandístico del estado moderno, alcanzaría la energía y los recursos a demostrar la idea de superioridad del americano respecto del europeo. No obstante su contraposición al euro-centrismo, no es ni ciega, ni injusta. Su sentido de la responsabilidad histórica y su visión holística de la vida le impedían volverse contra nada y contra nadie por simple espíritu de controversia. Su crítica es siempre de naturaleza ética y, por lo tanto, trata de evitar a toda costa las diatribas personales: "Yo no discuto jamás. Creo lo que creo firmemente, porque he meditado mucho antes de creerlo. Oigo, y si tienen razón cambio" (XXI, 183). También ha dicho a su amigo Manuel Mercado que muchas veces se silencia, por el temor de herir, aunque ve a su alrededor las oscuridades que los hombres traman.

Martí, no sólo conocía a su América mestiza, como él la llamaba, sino que conocía al dedillo la historia de Europa y de su tradición judeo-cristiana. Venía de estudiar su historia, su política, su economía, sus leyes, su cultura, su arte y su literatura y había hecho su síntesis de todos los factores de esa tradición por lo que podía penetrar sus inconsistencias, sus maquinaciones y sus contradicciones. Así revela a los europeos, como hará igualmente con los norteamericanos, una Europa y una América que no conocían. Es decir, expone sus entrañas a la luz pública y aclara el verdadero objetivo de sus empresas de rapiña. En tal sentido habría que preguntarse ¿quién descubre a quién? Esta vertiente discursiva contra-hegemónica en defensa de sus patrias azules será, como las demás, de hondas indagaciones, de directas y efectivas exposiciones de las fabricaciones de las "mentes sietemesinas" europeas, será, en fin, su contra-conquista.

Ciertamente, cuando los españoles llegan a la capital azteca encuentran una ciudad de tanto esplendor que sólo pueden describirla con el vocabulario de la ficción de 
su literatura caballeresca donde describían las ciudades de su imaginación, poblabas de maravillas. El mejor testimonio nos lo deja Bernal Díaz del Castillo, el soldado que acompaña a Cortés en su sangrienta conquista de México:

Y otro día por la mañana llegamos a la calzada ancha, íbamos camino de Iztapalapa; y desde que vimos tantas ciudades y villas pobladas en el agua, y en tierra firme otras grandes poblaciones, y aquella calzada tan derecha por nivel como iba a México, nos quedamos admirados, y decíamos que parecía a las cosas de encantamiento que cuentan en el libro de Amadís, por las grandes torres y cues y edificios que tenían dentro en el agua, y todas de cal y canto; y aún algunos de nuestros soldados decían que si aquello que veían era entre sueños. $Y$ no es de maravillar que yo aquí lo escriba de esta manera, porque hay que ponderar mucho en ello, que no sé cómo lo cuente, ver cosas nunca oídas ni vistas y aún soñadas, como vimos. $^{28}$

El cronista dice además que los palacios donde los albergaron eran "grandes y bien labrados" y sus habitaciones y sus patios eran amplios, adornado todo con maderas preciosas. Y luego que fueron conducidos al jardín "fue cosa muy admirable verlo y pasarlo, que no me hartaba de mirarlo y ver la diversidad de árboles y los olores que cada uno tenía, y [paseos] llenos de rosas y flores, y muchos frutales y rosales de la tierra..."29 Luego describe como las canoas podían entrar en el jardín por un canal, sin saltar a tierra, y todo construido con muchas piedras dibujadas, y aves de diferentes especies y que mirándolo bien no creía que hubiera nada parecido en el mundo por él conocido. Después de varios años de ausencia Bernal vuelve al mismo lugar y ahora es el cronista el que habla: "Ahora esta villa está por el suelo perdida, que no hay cosa en pie" (240). Es, como afirma Alberto Rivas Yánez, compilador y prologuista, la presencia de "las dos voces de Bernal, la del soldado y del cronista". El joven Bernal que ve "la hermosura y la rareza del jardín del palacio de Iztapalapa... y la visión desolada del presente desde el que 
narra un Bernal...que ha visto como la conquista ha supuesto la desaparición de muchos tesoros del patrimonio indígena" (240).

Los españoles destruyen lo que para ellos era ficción, es decir comienzan por destruir el texto arquitectónico americano, que era parte de la escritura maya. A todas luces la mentalidad ibérica no estaba preparada para su encuentro con una cultura, una lengua, una religión y un ser humano diferentes; no estaba pertrechada, ni ideológica, ni espiritualmente para el contacto con la alteridad. Eran "civilizados", pertenecían a la ciudad. Esa es la segunda falacia que construye Occidente para alimentar su eurocentrismo. Quien no vivía en la ciudad era un salvaje, como pasaron a ser la mayoría de los habitantes de América que vivían en las selvas del continente. La tercera será que la naturaleza en que vivían era inferior a la de Europa, lo cual contradice muchas de las crónicas de los soldados, que la describen como si fuera el paraíso. Esta visión desproporcionada, fantástica, libresca da origen, más tarde, a la tan llevada y traída fórmula Civilización vs. Barbarie. Por último crean la falacia de la inferioridad de la raza aborigen, prohijada hacia el siglo XVI con términos de la zoología con la cual completaban el cuadro necesario para justificar su empresa de conquista y colonización.

El "euro-centrismo" comienza a fraguarse hacia 1750 con las seudo-teorías de Buffon y Cornelius de Pauw acerca de la "inferioridad biológica" del Nuevo Mundo respecto de Europa. Para estos científicos de gabinete ("sietemesinos" como los llama Martí), la diferencia -en su mente retorcida- es sinónimo de inferioridad. Así para Buffon el puma de América es inferior al leén porque es más pequeño y no tiene melena y por tanto es más cobarde. Luego extiende esa idea a todos los grandes mamíferos, encontrando que todos los americanos son inferiores a los europeos. Luego añade la 
brillante teoría de que todos los animales europeos traídos a América se han disminuido. Si los animales del continente son pocos y pequeños y los importados se achican, entonces, por deducción, la naturaleza americana es hostil al desarrollo de éstos. Como nos dice Antonello Gerbi es fácil saltar del paralelo geográfico al genético: "Y en esta ruta, Buffon avanza impertérrito, haciendo extensiva a toda la 'naturaleza viviente' sus observaciones sobre los cuadrúpedos". ${ }^{30}$ Vale la pena, aunque brevemente, anotar algunas de sus palabras para constatar lo retorcido de las mentes de estos "pensadores de lámparas" que crearon y divulgaron en América y el mundo ideas tan absurdas, y de consecuencias tan nefastas para la historia moderna. Con ellas convierten al "hombre natural" de América -que ya es salvaje a la mirada extranjera- en ser inferior al civilizado europeo: "El salvaje es débil y pequeño en cuanto a sus órganos de generación. No tiene ni bello ni barba y carece de ardor para la hembra. Aún siendo más ágil que el europeo $[\ldots]$ es, sin embargo, mucho menos fuerte físicamente; es mucho menos sensible". ${ }^{31}$ De manera que este débil salvaje, concluye, no ha podido domeñar su naturaleza y por eso permanece virgen. Así este ser frío - para Buffon- está más cerca de los reptiles que del hombre, en consecuencia se arrastra y tiene la sangre aguada, a lo que contribuye la humedad del clima, causa de putrefacción y descomposición. De ahí salta a la idea de que América es un continente nuevo que ha estado sumergido bajo las aguas por más tiempo y por lo tanto no ha tenido tiempo de evolucionar lo suficiente. Luego concluye que la pequeñez es sinónimo de inferioridad y por lo tanto todo lo grande es superior, idea que hasta hoy permanece en la mentalidad occidental. Buffon parece haber olvidado a los saurios que desaparecen, mientras otras especies más pequeñas sobreviven. Ante la evidencia científica de otros que desacreditan sus elucubraciones él sencillamente 
las descarta porque no estaba en su naturaleza miope entrar en detalles, algo tan esencial a la observación científica.

Por su parte Comelius de Pauw -ya en plena Ilustraación- continúa la labor denigratoria de la naturaleza y el hombre americanos comenzada por Buffon. Dice que el hombre sólo puede desarrollarse en sociedad y "solo, en estado natural, es un bruto incapaz de progreso". ${ }^{32}$ Para él los salvajes de América no son sólo fríos e inexpertos, sino también degenerados y "tienen menos humanidad, menos gusto y menos instinto, menos corazón y menos inteligencia...Son como niños bobos, incurablemente ociosos e incapaces de cualquier progreso mental". ${ }^{33}$ Afirma que a causa del clima "muchos animales pierden la cola, los perros ya no saben aullar, la carne del buey se torna correosa y los órganos genitales del camello -que son los peruanos- dejan de funcionar" (54). Una pintura de la época le sugiere que el hombre aborigen tienen el cráneo cuadrado y en polémica con Garcilaso niega todo lo que éste narra de los Incas" ${ }^{\text {34 }}$, lo cual es una muestra fehaciente de la ceguera y la arrogancia de estos "pensadores sietemesinos". Ahora estos dos "excelsos" naturalistas no son los únicos que contribuyen a la difusión de estas ideas. A ellos se suma una larga lista de cronistas, historiadores, naturalistas, filósofos y viajeros con ínfula de escritores que se hacen eco de tales falacias.

\section{Dignificación del hombre aborigen}

Imagino cuan difícil, desde el punto de vista afectivo, debe haber sido para un pensador de la talla y entereza ética de Martí el tener que lidiar con la difusión en América de ideas que, por su naturaleza resultaban, por un lado, antinaturales, es decir, 
contrarias a la ciencia que practicaban estos señores "naturalistas" y, por otro, carentes de toda lógica, que era en principio el discurso privilegiado de la razón. Desde la década del 80 , cada vez que la oportunidad lo amerita, Martí arremete contra las falacias del eurocentrismo. Una de las seudo-teorías que con más insistencia desmiente es la de la superioridad racial y cultural. Parte del reconocimiento de que el otro es una prolongación suya, provisto de su misma humanidad esencial, más allá del color de su piel y sus rasgos fisonómicos, más allá de sus expresiones lingüísticas o culturales. Las diferencias del otro para Martí no anulan su ser, sino por el contrario, lo completan y mejoran. En La edad de oro comunica a los niños de América la idea de la igualdad racial porque entiende la importancia que tiene para la paz de los pueblos.

Estudiando se aprende eso, que el hombre es el mismo en todas partes, y aparece y crece de la misma manera, y hace y piensa las mismas cosas, sin más diferencia que la de la tierra en que vive, porque el hombre que nace en tierra de árboles y de flores piensa más en la hermosura y adorno, y tiene más cosas que decir que el que nace en una tierra fría, donde ve el cielo oscuro y su cueva en la roca. Y otra cosa aprende, y es que donde nace el hombre salvaje, sin saber que hay ya pueblos en el mundo, empieza a vivir lo mismo que vivieron los hombres de hace miles de años. (XVIII, 357)

Su objetivo es, fundamentalmente, resaltar las culturas aborígenes de América de los ataques y diatribas que contra ellos han forjado los científicos de gabinete europeos. Plantea que las civilizaciones precolombinas crecieron y se desarrollaron por ellas mismas, sin contacto con los demás pueblos del orbe y que por tanto no conocían de ciertos adelantos de éstos, como éstos a su vez no conocían de ciertos adelantos de los amerindios. Tal es el caso de la civilización maya que llega a alcanzar un alto nivel de desarrollo en diversas ramas del saber como la astronomía, las matemáticas, la escritura 
pictográfica, etc. De ahí su pensamiento ya citado de que en el espiritu de cada hombre están inscritas todas las edades de la naturaleza. Hay aquí una implicación ética tal como lo entiende la filosofia. La idea en el fragmento es sencilla: que un hombre es igual a otro hombre, no importa la indumentaria, o los discursos que lleve escrito cada uno en su cabeza, o si pertenecen a edades diferentes.

Como ya apuntamos estaba al tanto de los últimos hallazgos arqueológicos y desmentía las especulaciones seudo-científicas de ciertos personajes famosos de la época. A uno de los que le sale al paso es el abate Brasseur de Bourbourg a quien acusa de robar parte del patrimonio maya y en quien censura "aquellos ampulosos y ligeros comentarios suyos" (VIII, 339) en torno a la desaparición de la lengua yucateca:

Oímos hablar de la lengua maya como de un documento antiguo, de una civilización muerta, salvado del olvido en un libro de diego de Landa y revivida por las investigaciones del abate Brausseur de Bourbourg, americanista famoso. Pero es de saber que la lengua maya se habla aún en toda su pureza en algunos lugares de la América Central y que quien viaje por la comarca de los chacamules, que es una tribu de hombres barbados que habita en las cercanías de la antigua ciudad de Tekal, oye aún, como si viviera en los tiempos de Chilam-Balam, que fue una especie de Moisés yucateco, aquella lengua armoniosa. (XXIII, 198)

Martí quiere insistir en que el instrumento que sustenta la cultura aborigen, a pesar de los siglos de colonialismo en América, está vivo y si lo está, la cultura que esa lengua sustenta lo está también. Sólo habrá que emprender un proceso de reconstrucción de las ruinas, no sólo de las de piedra, sino también -de acuerdo al concepto de Walter Benjamín- de las ruinas de la tradición oral, de la tradición pictográfica, etc. Este es el reclamo martiano que subyace en esta defensa, por un lado, y la certeza de que lo que vendrá con la oleada del neocolonialismo acabará de arrasar esos remanentes de un 
pasado glorioso. Que Martí tenía razón en cuanto a lo que vio, respiró y vivió de la cultura maya en Guatemala dará testimonio varias décadas después Miguel Ángel Asturias en su trabajo de reconstrucción del alma y la cultura maya que es precisamente el tipo de arqueología que abogaba Martí, sumergirse en la cultura de los antepasados y abrazar sus piedras y sus ruinas como si fueran las propias, con profundo amor.

También sale en defensa de los indígenas del norte y afirma que los defectos que se les achacan no es consecuencia de su modo de ser natural, sino del sistema de vida que le ha sido impuesto por el colono blanco. Los defensores de los indios -nos dice- luchan por devolverlos a una vida "en que no sean como ahora, burlados sus derechos, engañada su fe, corrompido su carácter y sus revueltas frecuentes y justas" (X, 321). En su opinión, sacar a un hombre de su medio natural, imponerle formas y creencias que no armonizan con su visión del mundo y prostituirles el carácter es deshumanizarlo: "el indio no era así de natural, sino que así lo ha traído a ser el sistema de holganza y envilecimiento en que se le tiene desde hace cien años" (322). Después de despojarlos de sus tierras, de sus sembrados, de sus símbolos sagrados, con "tratados onerosos" los confinan en reservas estrechas y lo fuerzan a un sistema y a leyes contrarias a su naturaleza y a su sabiduría milenaria. Esto es, dice Martí, como desprender un árbol de sus raíces. Y agrega:

...lo fuerzan, so pretexto de cultivo, a comprar animales para trabajar una tierra que no es suya; lo compelen, so pretexto de escuela, a que aprenda una lengua extraña, la lengua odiada de sus dueños, libros de texto que les enseñan nociones vagas de letras y de ciencia, cuya utilidad no se explica y cuya aplicación no ve jamás; lo apresan en un espacio estrecho, donde se revuelve entre sus compañeros acorralados, con todo el horizonte lleno de los traficantes que le venden cachivaches relucientes y armas y bebidas en cambio del dinero que en virtud de los tratados reparte entre las reservas el Gobierno al año. Él no puede [...] salir de aquel potrero humano [...] 
puesto que el gobierno, por un sistema de tutela degradante que comenzó hace un siglo, le da para vivir un terreno en común. (323; énfasis míos)

Es decir, un ser humano habituado al ir y venir con entera libertad por la inmensidad de sus praderas, de sus montañas, en armonía con su paisaje, con sus árboles y sus piedras sagradas donde oficia sus rituales, es encerrado -como nos dice Martí- en un potrero, como un animal más y el progreso le humilla con una ciencia para él infructuosa y con los productos de su industria que le llena de "cachivaches relucientes". En estas condiciones se consuma el crimen puesto que este "indio es muerto, con ese sistema vil que apaga su personalidad: el hombre crece con el ejercicio de sí mismo..." (323) que es el mismo concepto que maneja Juan Francisco Manzano en su Autobiografia de un esclavo. Sin dignidad, ni libertad el hombre no existe.

Todo hombre esclavo es así, no es el indio sólo: por eso tan crueles son las revoluciones que vienen tras las prolongadas tiranías: ¿qué blanco que tenga el seso en su lugar no entenderá que no puede echar en cara al indio el ser como los blancos lo han hecho? "El es gentil y bravo -decía en la Convención el venerable Erastus Brooks-, cuya palabra ama y pesa: he aquí a decenas, a centenas, los ejemplos de la historia americana, que demuestran que el indio, en condiciones iguales, es capaz, mental, moral y físicamente, de todo aquello de que es capaz el hombre blanco". Pero hemos hecho de él un vagabundo, un poste de taberna, un pedidor de oficio. (324)

Esta polarización de fuerzas antagónicas produce en el aborigen un sentimiento de desarraigo, pues el colono no es capaz de entender que el indio es una raza que no entiende el concepto de la posesión de la tierra porque entiende que la tierra no se puede poseer y ha vivido por siglos en la libertad de la naturaleza, sin rejas, sin cercas, dependiendo de sus propias fuerzas y sus propias habilidades, escuchando el consejo, no 
de un patán que se ha hecho de un poco de dinero o de un cargo público, sino de los ancianos de la tribu. Finalmente dice que los blancos han depositado en el indio todos sus vicios y dogmas, de manera que si tienen un poco se seso verían en ellos su propio retrato deformado.

\section{La visión autóctona como antídoto contra el desarraigo}

Martí sabía con certeza que ni "el libro europeo, ni el libro yanqui, daban la clave del enigma hispanoamericano" (VI, 20). El tiempo ha venido una vez más a corroborar la certeza de sus reflexiones. Los hábitos de mando de los europeos y norteamericanos dejaban de lado, por intereses mercantiles, excesiva avaricia y la por ignorancia de la cultura que avasallaban, a la gran masa de los desposeídos y los "infelices" a los que había que "alzar en brazos" para "deshelar la América coagulada" (20). Martí insiste en la idea de la sangre coagulada del indio para dejar testimonio de que el discurso eurocentrista del salvaje americano, de la inferioridad de esa raza, si en algún sentido puede verificarse, es en la brutalidad con que el colonialismo quiso destruir todo el legado indígena, convirtiéndolo en el más excluido de todos los componentes de la hibridez étnica. Por esa misma razón proclama que América se paralizó cuando se paralizó al indio y que no andará bien hasta que no ande el indio, frase que aún hoy puede parecer desmesurada, puesto que el texto moderno ha venido rescribiendo en el cuerpo latinoamericano las mismas ideas del euro-centrismo y de la universalidad occidental de manos del neocolonialismo, o si se prefiere, del neoliberalismo corporativo o la globalización de la Europa del Norte de la cual Martí advirtió a las repúblicas del 
continente cuando dijo que había llegado la hora para América de librar su segunda independencia.

El discurso de la autoctonía martiano tiene la virtud, no sólo de ser el primer gran discurso de la hibridez americana, si no a la vez de ser el primer gran proyecto americanista como contra-discurso de los dos colonialismos en función, sino además de proyectar ese discurso como el verdadero programa de desarrollo, crecimiento y esplendor de la "América mestiza". Su misión educadora está dirigida a reconectar al latinoamericano con el pasado civilizado de las culturas aborígenes porque ve y entiende que ese es el verdadero antídoto contra el desarraigo para la conciencia latinoamericana. De ahí que insiste que nuestra Grecia desde los Incas al presente, pasando por el resto de las civilizaciones precolombinas, es mucho más importante y necesaria para el florecimiento de naciones prósperas que sean respetadas por los de "allá" del norte y los de "allá" de Europa. La crítica severa que despliega en cada espacio de que dispone contra los intelectuales de América que se desviven por lo foráneo, que están ebrios de la copia, del mimetismo y que, por esa misma razón, ven lo propio, lo autóctono como inferior se justifica por la peligrosidad y las consecuencias nefastas derivadas de tales actitudes. Es un arma, según él lo ve, para favorecer la injerencia y perpetuar el colonialismo en las tierras del sur. Por eso expresa que la colonia había seguido viviendo en la república y que esa inscripción debía ser borrada del texto americano para poder inscribir los signos esenciales subyacentes en el sub-texto original.

Otra cosa cree firmemente y es la idea de que el reconocimiento y la valoración justa y amorosa del legado cultural autóctono es la mejor defensa contra la injerencia. "Una idea enérgica, flameada a tiempo ante el mundo para, como la bandera mística del 
juicio final, a un escuadrón de acorzados" (VI, 15). Y más adelante consigna con claridad meridiana lo que es una premonición, una de sus llamadas de alerta a Nuestra América: "¡los árboles se han de poner en fila, para que no pase el gigante de las siete leguas! Es la hora del recuento, y la marcha unida, y hemos de andar en cuadro apretado, como la plata en las raíces de los Andes" (15). Al letrado oficial que tiene los ojos puestos en las capitales europeas, a ese intelectual que quiere emprender el deseado viaje a París, le dice que mire en su paisaje y en su herencia para que encuentre la verdadera savia que ha de cantar en sus odas. El viaje no es hacia el exterior, sino hacia el interior. Por primera vez alguien está consignando que el viaje no es el clásico viaje occidental del guerrero que regresa a encontrarse con la esposa que teje y desteje la misma tela, el mismo texto; ahora el viaje es hacia el pasado, a desenterrar el texto sepultado por la conquista, ese que contiene las claves y los signos que han de producir el ordenamiento del caos, que posibilitará unir los fragmentos dispersos, contaminados de cuerpos extraños al texto original. Es el mismo viaje que emprenden después tantos intelectuales del continente en el siglo XX que entienden el reclamo que él había entendido un siglo antes. Es el de Asturias en Hombres de maiz hacia el interior del mundo maya, hacia la tierra del ensueño; es el viaje de Carpentier en busca de Los pasos perdidos, de los orígenes, remontando el Orinoco; lo es igualmente el de Arguedas hacia Los ríos profundos del alma quechua, de la mito-poesía de la raza incaica. Es el viaje hacia el interior del texto maya, del texto náhuatl, del texto quiché, hacia el interior de lo autóctono, para encontrar lo original como antídoto contra el desarraigo. Estos no agotan el repertorio, pero es la respuesta de la intelectualidad del continente en la búsqueda constante de la identidad americana, del texto cartesiano. 
Ese es el viaje invertido que emprende Martí hacia el corazón de América, con amor entrañable, que es casi sagrado, contrario al de la modernidad en cualquier sentido que se piense. Busca los signos enterrados de civilizaciones que conservaban vivos los mitos fundacionales en los libros abiertos, los textos inacabados de los escribas; de pueblos que no habían jerarquizado la razón como el instrumento perfecto e infalible del existir porque no creían ser el centro del universo, ni mucho menos que podían transformarlo o degradarlo. Como corredor de fondo, con una resistencia inusual, Martí sabía que su verdadera cosecha demoraba, como suele suceder cuando viajamos a contracorriente. Liberado del fantasma de la fama y la gloria como estuvo, y del fantasma del Dios cristiano siguió su viaje invertido porque concebía su escritura ética para el porvenir que no estaba en el futuro de la modernidad, sino en el origen de la tradición. El arqueólogo que se revela en su escritura es el pensador comprometido con la verdad, es el anticolonialista, el antiimperialista, es en fin, el que revela en ella una subjetividad situada en las antípodas de la subjetividad del proyecto civilizador de Occidente. Trazar el mapa espiritual de esa subjetividad, fundir de nuevo todos los hilos rotos, se convierte en el sentido último de su viaje a la tradición con el firme propósito de reinsertarla en el texto y el contexto de la América mestiza, liberada de todo coloniaje, de toda imposición epistemológica u ontológica ajena a sus esencias, contrarias al pragmatismo utilitario e individualista patrocinado por el euro-centrismo y su proyecto colonial. 
1 John Guillory. "The Ethical Practice of Modernity: The Example of Reading" en The Turn to Ethics, (New York, Routledge, 2000)

2 Fina García Marruz. "El escritor" en Temas martianos, 207.

${ }^{3}$ Simon Critchley es uno de los filósofos ingleses más importantes de las últimas décadas, y quien ha estado en la vanguardia de los estudios culturales, analizando fundamentalmente la vinculación de esta disciplina con la ética. Es en este punto donde se cruzan sus pasos con los de Martí.

${ }^{4}$ Simon Critchley. "Why I love Cultural Studies" in Interrogating Cultural Studies: Theory, Politics and Practice. Londres: Pluto Press, (2003), 59-75.

${ }^{5}$ Cristobal Colón. Los cuatro viajes del almirante. (México: Espasa-Calpe, 1994).

${ }^{6}$ Miguel de Mongtaine. Ensayos completes. (México: Editorial Porrúa, 1991), 155.

${ }^{7}$ Roberto Fernández Retamar. Todo Calibán. (La Habana: Letras cubanas, 2000), 158.

${ }^{8}$ Mircea Eliade. Historiador, etnólogo y escritor rumano (1907- 1986). Es una de las máximas autoridades en la historia de las religiones. Nos referiremos, fundamentalmente, en este capítulo a El mito del eterno retorno. Madrid: Alianza Emecé, 1972.

${ }^{9}$ Julio Ramos. Contradicciones de la modernización cultural en América Latina: José Martí y la crónica modernista. Esta disertación fue presentada ante la facultad de la Universidad de Princeton en defensa de la candidatura del grado de Doctor en Filosofia en el mes octubre de 1986.

${ }^{10}$ Ramos, 372 .

"Ramos, 372.

${ }^{12}$ Ramos, 373.

${ }^{13}$ Ezequiel Martínez Estrada. Martí revolucionario. (La Habana: Casa de las Américas, 1974).

${ }^{14}$ Libro de Chilam Balam de Chumayel, Universidad Nacional Autónoma de México, México, 1973.

15 Jacques Derrida. La diseminación. (Madrid: Espiral/Fundamentos, 1975), 149.

${ }^{16}$ Derrida, $152-153$

${ }^{17}$ The portable Jung, editado por Joseph Campbell, (New York: Penguin Books, 1976), 56. De acuerdo a Jung en la psicología del ser humano está representado el "inconsciente personal" donde habitan todas las represiones intencionales del dolor y las emociones, pero también por encima y por debajo de este inconsciente están las cualidades que no son adquiridas sino heredadas. "En este profundo estrato también encontramos el $a$ priori, formas innatas de la "intuición", a saber, los arquetipos... Los instintos y los arquetipos juntos forman el "inconsciente colectivo. Los llamo "colectivo" porque, a diferencia del inconsciente personal, no está formado por lo individual... sino por aquello que es universal y de ocurrencia regular [...] El inconsciente colectivo consiste en la suma de los instintos y su correlato los arquetipos. De la misma manera que todo el mundo posee instintos, también posee una reserva de imágenes arquetípicas". (Traducción mía)

${ }^{18}$ Fina García Marruz. Darío, Marti y lo germinal americano. (La Habana: Ediciones Unión, 2001). 
${ }^{19}$ Jung, 318.

${ }^{20}$ Jung, 321 .

${ }^{21}$ Cintio Vitier. "Una fuente venezolana de Marti" en Temas martianos I, (La Habana: Letras Cubanas, 2004).

${ }^{22}$ Según cuenta Cintio Vitier en su ensayo "Una fuente venezolana de Martí", incluido en Temas martianos 1 , y en el cual glosa los escritos de Arístides Rojas, Tamanaco fue un cacique de los mariches apresado por los españoles en la batalla de Guaire a quien éstos encerraron en un circo de cañas y madera para enfrentarlo a un perro de presa, ofreciéndole el perdón si salía victorioso. El animal degüella al indio en la dispar batalla. Vitier cita a Rojas quien en sus Estudios indígenas. Contribución a la historia antigua de Venezuela. Caracas, Editorial Cecilio Acosta, 1941, narra lo siguiente: “Cómo calificar este hecho? ¡Resucitar los horrores del Circo Romano en la plenitud del Cristianismo, a los quince siglos de haber derribado la Cruz los ídolos del Capitolio! Afortunadamente en la Historia, la ley de las compensaciones sostiene el equilibrio, y la verdad moral resplandece como el sol. Hacia cinco años que cerca de esos mismos lugares, Guaicaipuro había resucitado la época heroica de Gracia, y moría como Leónidas con sus espartanos en las Termópilas de los Teques, en nombre de la patria, de la familia y del honor" (51-52). Martí le dedicó el poema "Tamanaco, de plumas coronado" (XVII, 237) basándose en los datos y la información que adquirió leyendo a Arístides Rojas.

${ }^{23}$ Cintio Vitier nos da noticia de quien es Arístides Rojas en el ensayo antes mencionado. Según el crítico cubano es un médico, científico y escritor venezolano nacido en 1826, amante de la arqueología y la etnografía, admirador de Humbolt, tanto que después de su muerte publica una serie de trabajos bajo el nombre de humboldtianas. Cuando Martí llega a Caracas en enero de 1881 ya Rojas gozaba de un sólido prestigio científico y había publicado varios libros: Un libro en prosa, La península de los caracas, Ensayo de un diccionario de vocablos indígenas y el ya mencionado Estudios indígenas. Martí incluye en su primer número de la Revista venezolana una nota de elogio al investigador venezolano quien es, además, el que facilita los recursos cuando Martí tiene que salir de Caracas intempestivamente, una vez más por roces frontales con el poder.

${ }^{24}$ Roberto Fernández Retamar. Todo Calibán. (La Habana: Letras cubanas, 2000), 51.

${ }^{25}$ De ahí la importancia y trascendencia que para las tres grandes civilizaciones precolombinas poseen las piedras, no sólo como marcas del tiempo (la Piedra Solar, los Katunes), sino además porque en ellas residen espíritus y deidades vinculados a su vida cotidiana.

${ }^{26}$ Mircea Eliade. El mito del eterno retorno. (Madrid: Alianza/Emecé, 1972).

${ }^{27}$ José Martí. Poesía completa. (La Habana: Letras Cubanas, 2001).

${ }^{28}$ Diaz del Castillo, Bernal. Historia verdadera de la conquista de la nueva España. (Madrid: Castalia Didáctica, 1999), 238.

${ }^{29}$ Diaz del Castillo, 239-240.

${ }^{30}$ Antonello Gerbi. Viejas polémicas sobre el Nuevo Mundo, (Lima: Banco de Crédito del Perú, 1946), 14.

${ }^{31}$ Gerbi, 15.

${ }^{32}$ Gerbi, 5 I.

${ }^{33}$ Gerbi, 54.

${ }^{34}$ Gerbi, 55 . 


\section{Capítulo V}

\section{El paradigma ético de la escritura martiana}

Puedo hacer dos libros: uno dando a entender que sé lo que han escrito los demás: -placer a nadie útil, y no especial mío. Otro, estudiándome a mí por mí, placer original, e independiente. Redención mía por mí, que gustaría a los que quieren redimirse. Prescindo, pues, de cuanto sé, y entro en mí Ser.

José Martí "Juicios"

\section{Introducción}

Entre los estudiosos de Martí es Cintio Vitier quien en Ese sol del mundo moral: para una historia de la eticidad cubana ha trazado el perfil más cordial del universo ético del poeta cubano. Sin embargo, siendo esta matriz la dominante de su escritura, que escomo su mismo creador reconoce- una tupida selva, queda mucho camino por recorrer en la valoración y alumbramiento de esta visible y a la vez invisible formación discursiva. Otros discursos de su obra han sido analizados con más atención e interés por tratarse de aspectos relacionados con la inmediatez de los fenómenos sociales y políticos de su hora, aunque como se verá todas esas corrientes discursivas convergían en su escritura ética, centro de gravedad de todo el magma de su creación. Los estudios de los últimos cincuenta años -que a su vez absorben los hallazgos teóricos de la primera mitad del siglo XX- en los campos de la lingüística, la filosofía, la antropología, la ética y la teoría y la crítica literaria, han venido a alumbrar con mayor nitidez las capas del substrato 
profundo de su escritura. No se puede negar que Martí ha contado con fervientes y talentosos críticos que a lo largo de casi una centuria se han asomado a su palabra y alumbrado, con una sólida exégesis, páginas memorables de esa por Gabriela Mistral llamada mina inacable. Muchos de estos apasionados críticos aparecen igualmente aquí, alumbrando las páginas de este proyecto.

Pero una obra tan extensa y compleja, que resiste y desborda los horizontes estrechos de los movimientos, escuelas, sistemas, doctrinas o épocas, como hemos visto, y que además se re-actualiza constantemente, sobre todo a la luz del nuevo instrumental teórico que nos ofrece la filosofía contemporánea, continuará produciendo nuevos y felices alumbramientos. Y esa demanda aparece ya en Cintio Vitier cuando dice en "Una fuente venezolana de Marti", refiriéndose a su ensayo "Nuestra América" y la riqueza simbólica que éste encierra: "Explicar todo su sentido nos llevará un tiempo insospechado, pero ya es hora de empezar a leer a Martí con sistematización hermenéutica y rastreando, en lo posible, las fuentes de que se ha nutrido, para transfigurarlas, darles nueva figura de trascendente eficacia política" (247). Yo diría, para precisar un poco más, darles su verdadera y trascendente eficacia ética, que está más en el centro de su creación, que su eficacia política, que es circunstancial y estratégica. Mis relecturas de Martí en los últimos años comenzaron a resonar en la teoría y la crítica contemporáneas y cada vez se me hacían más evidente las correspondencias que había entre Martí y la obra filosófica de Nietzsche, Wittgenstein, Heidegger, Kristeva, Foucault, Derrida, y otros que menciono a lo largo de este texto. Pero sobre todo, para mi constituyó una revelación haber descubierto, en el proceso de la investigación, la filosofía ética de Emmanuel Levinas, En ella descubrí una fundamentación teórica de primer 
rango de lo que concebía como la escritura ética martiana: ese complejo organismo que dice más de lo que esta en la letra y la base de todo el edificio de su creación artística no era, como algunos pensaban la política, sino la ética.

En la lectura y análisis de la filosofía ética de Levinas sentía la extraña sensación de que el filósofo estaba haciendo una fundamentación filosófica de las ideas martianas. Como Martí, cuestionaba la filosofía, pero no un fragmento, no un sistema específico, sino toda la filosofía occidental. De manera que para mí ya Martí no estaba sólo en su intento de pensar el mundo y la realidad fuera de ella o como crítica a ese pensar racional originado en la Grecia clásica. En otras palabras en Levinas encontré comprobada mi sospecha de que Martí pensó el mundo a través de la ética -que en última instancia es la materia de su poética- y no de la política como algunos de sus críticos han visto. Lo que Martí había desentrañado de la verdad del mundo a través de su prodigiosa intuición poética, Levinas lo había hecho a través de un altísimo nivel ético-filosófico. En la tarea de fundamentar el pensamiento ético martiano nos ayudará su propia biografía, los críticos que han explorado estas zonas con mirada órfica y la teoría contemporánea, siguiendo la huella de los filósofos mencionados a los que se suman otros como Adorno, Horkheimer, Crithley, etc., quienes de un modo u otro han aportado al estudio y alumbramiento de los ríos subterráneos y profundos de la subjetividad ética.

Ahora bien, nuestro estudio de la escritura ética martiana como un nuevo paradigma no arranca de las ideas tradicionales sobre la ética, o de los códigos morales prohijados a la sombra la tradición judeo-cristiana, una teología que al hacerse del poder, desnaturalizó los principios originales del pensamiento pagano y la filosofía presocrática, y sometió los símbolos a un proceso de falseamiento y manipulación. Ésta, si se quiere, 
"politización de la ética", emprendió una cruzada de jerarquización de valores en el marco de un dualismo maniqueo de categorías opuestas entre bien y mal que, ciertamente permitió ejercer un control absoluto de almas y haciendas, pero empobreció la riqueza y complejidad de la subjetividad del ser humano y lo embarcó en un período de oscuridad que se prolongó por varias centurias. Tal aproximación a la escritura martiana, hubiera dejado en la sombra zonas esenciales de su aprehensión del mundo, de los alcances de su lenguaje y de su modo arquetípico de "ser humano para la ética", es decir de una de las subjetividades más complejas y diversas del pensamiento occidental moderno. De modo que esos códigos morales que Wittgenstein llamaba "la charlatanería sobre la ética" no es la base de nuestro estudio de la escritura martiana. El nuestro toma como punto de partida las teorías éticas contemporáneas que se han nutrido de los alumbramientos aportados por lo más reciente del pensamiento filosófico, lingüístico, psicológico y las nuevas tendencias del pensamiento científico - sobre todo de la física cuántica- que comienza a regresar de la prolongada embriaguez de infalibilidad de sus teorías y sistemas a reconectarse con el espíritu, algo que Martí había predicho de manera deslumbrante. "Cuando el ciclo de la ciencias esté completo, y sepan cuanto hay que saber, no sabrán más que cuanto sabe hoy el espíritu, y sabrán lo que el sabe" (XIII, 25). Esto que ya sabían los místicos y el pensamiento oriental más avanzado, vuelve a resonar hoy en el ámbito de la ciencia como una certeza y cada día es más aceptado como un nuevo paradigma.

A partir de la Ilustración se produce una racionalización de la ética $y$, en consecuencia ésta se convierte en un instrumento de exclusión y represión; en un instrumento colonial. Martí, que entiende que la ética no puede limitarse a normas que 
una cultura impone como valores universales sobre el resto, elabora su escritura ética más allá del cogito racional, pues para él la ética es una manifestación de la identidad del ser humano, de su presencia en el mundo y no de una posición política, cultural o racial. Después de un intenso proceso de meditación Martí arriba a la certeza de que su explicación del ser y la realidad no pueden partir del discurso racional y que su espíritu y su ser disienten de la moral cristiana, del historicismo lineal y el progresismo teleológico que la modernidad ha elaborado como meta-narrativas. Su oposición resulta del hecho de comprobar cómo estas fabricaciones han incidido directamente en la exacerbación del ego del hombre occidental $\mathrm{y}$, en tal sentido, es un ser cerrado a la alteridad, cuyo horizonte de aprehensión de la realidad permanece en la identidad y la semejanza. La intolerancia y el dogma de su tradición disminuyen severamente las expresiones de sus sentimientos -verdadero canal de apertura a la otredad-, y aumenta su capacidad de racionalización de la realidad, que es la clausura de la subjetividad altérica. La oposición que se da en su contra-discurso de las dos modernidades; la estética y la burguesa, por un lado, y su discurso de la autoctonía, por el otro son, en esencia, el fundamento de su escritura ética que no está en la razón, que divide y excluye, sino en el amor, que convoca y hermana. De ahí que no proponga ninguna doctrina, porque entiende, como los griegos en su época, que el saber ético -que es práctico-y llamaban Frónesis, está por encima del saber teórico que llamaban Sofia. Por ese motivo pone en práctica su individualidad reconquistada para la libertad y el amor y desde la ética le tienda su abrazo al otro como extensión y completez de sí mismo, como realización plena y absoluta de su ser, como verdadera trascendencia. La personalidad martiana es, para usar un término de Levinas, una personalidad abierta a la hospitalidad, como en el hombre natural. 
Pocos escritores del siglo XIX estaban tan excepcionalmente pertrechados filosófica y poéticamente para ser creadores de paradigmas como la estaba Martí. Él, que vive un siglo de acumulación, de multiplicación, de expansión en todos los órdenes de la vida, entiende desde muy temprano, que para estar al nivel del tiempo que se vive hay que llegar a la raíz de lo real, porque "es cosa grave esta vida" y no podrá nunca penetrar las esencias de la vida y del mundo -que es decir entrar en la verdad-quien se quede en las ramas, embriagado en la melodía de las pájaros, pero ignorando la fuente de sus cantos. Por dos siglos la racionalidad de la Ilustración ha incrementado los discursos, las disciplinas, las doctrinas, las teorías, los sistemas, las narrativas. Elevarse por encima de esa explosión logocéntrica del "progreso moderno" y del desarrollo científico-técnico con todos sus metarrelatos requiere de una síntesis de excepcional energía, una mirada órfica y un saber que sea expresión del resumen de diversas civilizaciones, de una mente que pueda pensar el mundo más allá de las estructuras limitadas del racionalismo. El poeta cubano estudia profundamente la cultura occidental desde sus inicios y vive la experiencia de la modernidad en sus centros más importantes. Y no las estudia como viajero ocasional que se recrea en el pintoresquismo del paisaje o las impresiones seductoras de las vidrieras lujosas de las grandes avenidas, o de las luces artificiales que apagan el concierto mágico de las estrellas en el cielo. Realiza una profunda arqueología de ellas y bebe en sus textos sagrados lo esencial, al punto de incorporarlos a su cosmovisión. Ahora bien, la escritura ética martiana, siendo una formación discursiva polifónica, no sólo en su constitución genérica, sino igualmente en su calidad y volumen, no puede agotarse en estas páginas. De modo que esto es sólo el principio de una 
indagación en la zona realmente maravillosa de su creación que habrá de continuarse en proyectos sucesivos.

\section{La escritura martiana y las teorías de la ética contemporánea}

La escritura martiana encuentra una singular correspondencia con las teorías contemporáneas sobre la ética. Una aproximación analítica de la metafísica de Levinas y la deconstrucción de Derrida produce la agradable sorpresa de ver filosóficamente fundamentadas las más importantes ideas que atraviesan e informan tanto la escritura, como el ser martianos. Aunque no son los únicos filósofos en hacer de la ética su campo de investigación predilecto, son quienes se sitúan en la vanguardia del pensamiento ético en la segunda mitad del siglo XX. De ahí que base mi análisis fundamentalmente, aunque no exclusivamente, en sus teorías. Doy inicio con la dimensión crítica, importante en la teoría levinasiana que ampliaré más adelante cuando toque las ideas de la doble lectura de Derrida. Para estos dos pensadores la crítica se sitúa en el centro de la ética, y ésa es, precisamente, la primera instancia que los acerca al pensamiento de Martí, quien hace de su escritura toda una institución crítica del pensamiento moderno. Ahora bien, el concepto de crítica que maneja Martí es muy singular. En principio es "el ejercicio del criterio y luego la critica "es salud" y "es amor". Allí donde el hombre ejerce la crítica y defiende su original libertad despojado de todo terror le es posible construir su ser para la vida y expandir su humanidad, al tiempo que pueda deshacerse de todo discurso engendrado fuera de la veracidad. Lo primero que llama la atención es como Martí establece una crítica del pensar filosófico en un ambiente y una época en la cual el 
filósofo conservaba aún -a pesar de la relevancia que había cobrado el científico- cierto prestigio y jerarquía dentro del pensamiento que ya había perdido el poeta. Recordemos que Martí ha renunciado a la institución literaria tal y como se concibe en su época pues no le interesan las posiciones esnobistas, ni elitistas, ni está dispuesto a entregar su pluma a ninguna autoridad que limite la expresión de su libertad incondicional. Ahora podemos ver que tampoco le interesaba el filosofar, aunque pudo haber estado entre los más celebrados del siglo XIX. Pero como el ve más allá de lo aparente -y ahora se podrá entender cómo esta afirmación no es mera palabrería- porque lo hace a través del amor (que no es razón) y porque ha elegido la ética para instaurar su ser y reafirmar su humanidad y su dignidad en el ámbito de la responsabilidad, del deber, de lo justo, puede también ejercer la crítica en el cuerpo de la filosofía.

Para comenzar la exploración de su dimensión crítica, expresión de su escritura ética, entremos en "Juicios"2, texto breve donde resume sus ideas en cuanto a la filosofía e intenta responder a las preguntas que el hombre se ha venido haciendo desde que comenzó a tener conciencia de su lugar en el mundo desde el mismo origen de la sociedad. Es de una inusitada sencillez y demuestra cuán profundo había penetrado Martí las estructuras políticas de su momento y cuan depurado estaba su instrumental hermenéutico. Esa penetración se expresa en la lectura que hace de un fenómeno -que si bien no es nuevo- en la modernidad se constituye como práctica cuya especificación en la esfera política ha contribuido de manera significativa al deterioro y erosión de los principios democráticos. Me refiero al intento por parte de las estructuras del poder de silenciar la crítica dirigida a las instituciones o sistemas establecidos por el poder hegemónico para el dominio y control de las fuerzas sociales. La crítica sana es para 
Martí una forma de manifestarse el espíritu del hombre porque está en el hombre destruir las barreras que los discursos imponen a la libre expresión de la humanidad del hombre. Sus ideas sobre qué es y debe ser la crítica ya estaban maduras hacia 1879 cuando las expone en sus notas para el discurso sobre Echegaray pronunciado en el Liceo de Guanabacoa ese mismo año. O sea, que desde muy temprano Martí siente la necesidad de delinear cual es la esencia de ese discurso -que es más que eso, es una actitud vital puesto que ha percibido la violencia con que el poder colonial ejerce violentamente silencio en el hombre. En su definición intenta establecer a la vez una verdad -para él incontestable-, y una estrategia. Su verdad es que la crítica "es el ejercicio del criterio" y como tal se da como una necesidad natural en el hombre que debe ejercerla para poder ordenar el mundo que le ha sido otorgado y en ello mejorarlo. Es la necesidad que da origen al pensar filosófico. De ahí que exprese: "Destruye los falsos ídolos, pero conserva en todo su fulgor a los dioses verdaderos. [...] Criticar es amar." (XV, 94). Ejercer el criterio, en tanto es una expresión de la naturaleza del ser que va dirigida al otro, es el resultado del ejercicio del amor humano, es una expresión de los sentimientos más genuinos del hombre. En suma, es una expresión de la eticidad del ser volcado a la alteridad incondicional.

Esta concepción martiana de la crítica -de la expresión ética del ser- es una de las más originales y poéticas que se hayan dado sobre la crítica, no sólo porque conjura la negatividad que el poder quiere asociar y ha asociado con tal ejercicio, sino porque da en el centro mismo de su esencia. El hombre ejerce la crítica a través de su pensar y con el instrumento prodigioso de comunicación que es su lengua. La ciencia ha demostrado que el hombre es su ser social que se realiza en la comunión y la comunicación con sus 
semejantes. De manera que si puede ejercer el criterio, es decir aportar con las luces de su mundo interior, alumbramientos que ayuden a ordenar el caos que es la vida en cualquier sociedad, mantiene su equilibrio emocional y el de sus congéneres. Una, porque su palabra es escuchada, su ser se da; otra porque su amor encuentra un cauce, una vía para llegar al otro y entregarse en la epifanía de la solidaridad. Si el acto de amor es establecer el diálogo con el otro, entonces constituye una defensa de la humanidad del otro. Además Martí también entiende que la crítica es salud porque si se da como expresión de amor y éste para él es un fármaco, entonces ejercer la crítica es un modo de mejorar y mantener la salud. En resumen, el pensar martiano establece que el ejercicio del criterio es salud y es amor, las dos condiciones esenciales a la existencia y realización del ser humano en equilibrio y armonía. Por tanto, para la institución del poder cancelar, reprimir, desvirtuar o eliminar la crítica, será siempre un ejercicio de violencia y de violación de los derechos elementales y naturales del hombre puesto que no puede eliminar sus instrumentos de comunicación y pensamiento. Esta definición no nace -y en eso radica su belleza- de su pensar filosófico, sino de su intuición poética. De ahí su lucidez metafórica, pero a la vez su profundidad filosófica en una admirable sencillez. En consonancia con estas ideas martianas hay un pensamiento de Hannah Arendt que las especifica:

La palabra que no es escuchada no es proyecto sino impotencia, ficción, frustración. Sólo donde cada uno pude hacerse escuchar la política es auténtica, subsiste en cuanto a política. La palabra no escuchada se pierde, no es nada. La vox claman in deserto no es en absoluto vox... Además, ahí donde la palabra no pueda ser escuchada, comienza la limitación de la libertad. $^{3}$

Martí defiende esta idea en "Juicios" que es de la misma época cuando dice: "La crítica no es la censura; es sencillamente y hasta en su acepción formal -en su etimología 
-es eso, el ejercicio del criterio" (XIX, 366). Si seguimos las reflexiones de Martí y de Arendt podemos concluir que la imposibilidad de ejercer la crítica se convierte en imposibilidad de ejercer el ser y, en consecuencia, a un lento pero seguro proceso de deshumanización. Es una doble represión de la naturaleza humana, a nivel físico y espiritual, es una represión desde el exterior y en el interior. ¿No será esta práctica de neutralización del "ejercicio del criterio" por parte del poder hegemónico el germen de la esquizofrenia, la psicosis colectiva y el creciente nivel de suicidio que se detectan en número cada vez más alarmante en la sociedad contemporánea y que éste trata de paliar con la psiquiatría y el psicoanálisis? Varios pensadores contemporáneos han respondido afirmativamente a esta pregunta. Pero hay otras dos ideas capitales en este texto, si consideramos que no era una crítica común para la época en que Martí la hace. La primera se refiere a la manipulación del saber, del conocimiento, de la cultura por parte de la élite que, a mi modo de ver, está en la base de la teoría hegemónica que más tarde desarrolla Gramsci -referida ya en capítulo anterior- y la otra se acerca a los análisis de Foucault, con relación al ámbito de la medicina que el filósofo francés desarrolla, fundamentalmente, en El nacimiento de la clínica. Según Martí:

Se dice por los espíritus temerosos, (léase el poder) que no conviene a pueblos nacientes conocimientos de este género, que podrían llamarse de acabamiento y perfeccionamiento del espíritu.

Esto, dicen, no es una droga y no se vende: no es, pues, útil como la Farmacia. No es una yerba, y no sana: no es, pues, útil como la Medicina: no es una ley, no se dice en latín, no se aplica el tiempo de Alfonso el Sabio a los pueblos de Bolívar; no es útil, pues, como nuestro derecho. ¡Ah! De manera que esta avaricia de cultura, esta inquietud de cosa nuevas, ese dolor de no saber las cosas que otros hombres saben, que a mí me ha hecho muchas veces verter llanto amargo, ese anhelo de conocerse a sí mismo, esa plenitud y brío de espíritu que se alcanzan con la cultura de la educación; ; todo ese mundo invisible sí, pero creador, pasa como 
inútil, y hasta pernicioso para los hombres mismos cuyo primer artículo de fe es la invisibilidad de un creador! ¡Niegan al Dios que creen en cuanto no les aprovecha! (XIX, 366; énfasis míos)

El fragmento es susceptible de ser sometidos a la cirugía deconstructiva de Derrida por la ramificación de ideas que contiene, pero entremos, al menos ahora, en las más sobresalientes. En el primer párrafo señala la inconveniencia de divulgar la verdad porque, según el poder, no es rentable, con lo cual critica esta aberración de convertir la verdad en una miserable mercancía como si hubiera precio a la verdad. No es droga, no es medicamento, no es ley romana, no es útil. Aquí se expresa en toda su crudeza el comercialismo instaurado en las urbes modernas, y como ha penetrado todas las esferas de la vida, que después pudo ver en su expresión más acabada cuando vino a residir a Estados Unidos en 1880 . Sobresale, además, la referencia que hace a la cultura y a su manipulación y al calificativo de inutilidad que señala para las cosas que tienen que ver con la educación que proporciona el conocimiento del espíritu humano. Eso tampoco es rentable, y por el contrario, es peligroso. ¿Será, acaso, igualmente deleznable? Finalmente hay una crítica implícita de la hipocresía y el cinismo típico de la élite gobernante que cree en Dios cuando le favorece económica o políticamente, pero lo ignora cuando se revela en la forma original y auténtica, cuando viene como el liberador de almas, el humilde predicador, el perdonador, el amador del prójimo. Esas prácticas, más de un siglo después de ser denunciadas por Martí, continúan siendo moneda corriente en la democracia norteamericana.

Como expresamos antes es Michel Foucault quien desarticula y devela en textos como Historia de la locura, El nacimiento de la clínica y Vigilar y castigar las 
interioridades de las estructuras del poder que el estado moderno ha creado para ejercer control absoluto, que llegan al límite de invadir y legislar incluso el cuerpo humano -lo que él denomina como biopoder- expresado en la manipulación y control de las enfermedades, de la medicina y de la legalidad. A este control del cuerpo humano se suma la manipulación y el control ejercido por el aparato propagandístico en la esfera cultural e intelectual. De tal modo que las dos dimensiones del ser humano -la corporal y la espiritual- quedan incorporadas a la vigilancia y el castigo de la entidad hegemónica. Así Martí, en el fragmento citado, nos da adelantos de lo que será más tarde uno de los enfoques filosóficos más extensos de Michel Foucault quien a su vez es uno de los pensadores del siglo XX que más hondamente ha deconstruido todo el andamiaje del binomio poder-saber.

Hay un instante esencial de la escritura martiana, no por causalidad también de 1882, que puede verse en su ensayo "Emerson", donde aparecen frases que, a pesar de estar dichas a propósito del pensador norteamericano, -por ese concepto ético suyo de que "Honrar, honra"- constituyen una magnífica descripción de su propio ser ético y pueden muy justamente decirse de él mismo. Martí entiende que el poeta de Concord no “obedeció a ningún sistema, lo que le parecía acto de ciego y de siervo; ni creó ninguno, lo que le parecía acto de mente flaca, baja, envidiosa" (XIII, 16). Esa es su propia actitud vital, su modo de ver y actuar en el mundo. Ni obedeció sistema porque para su mirada órfica eso era ceguera, ni creó ninguno tampoco porque $-\mathrm{y}$ aquí los adjetivos son importantes- eso era para mentes flacas, es decir, llenas de las mismas oquedades de los falsos eruditos que menciona en "Nuestra América"; mentes bajas y envidiosas que necesitan alimentar el egos como modo de realización personal. Vuelve aquí a insistir en 
la idea de la "reconquista del ser" y dice que Emerson "se sacudió de los hombros todos esos mantos y de los ojos todas esas vendas que los tiempos pasados echan sobre los hombres, y vivió faz a faz con la naturaleza, como si toda la tierra fuese su hogar" (14), más allá de las fronteras políticas y religiosas.

Cuando el hombre se despoja de todos los meta-discursos -en el lenguaje martiano "todas esas vendas"- que el poder echa sobre los hombres como lianas, vuelve a estar de frente a la naturaleza que no tiene fronteras, su patria primera, inscrita aún en los arquetipos de su inconsciente, libre, digno, justo. En la primera página del ensayo dice que la naturaleza es "templo" y "profanación" el comercio de la ciudad, dándonos "el hombre natural" que es él, esencialmente ético, el que se realiza en la alteridad, en el abrazo común con la tierra y sus hermanos en la comunidad. Por eso dice en este fragmento, que es hipertélico y por tan contr-moderno, como los mejores suyos.

Puedo hacer dos libros: uno dando a entender que sé lo que han escrito los demás: -placer a nadie útil, y no especial mío. Otro, estudiándome a mí por mí, placer original, e independiente. Redención mía por mí, que gustaría a los que quieran redimirse. Prescindo, pues, de cuanto sé, y entro en mí Ser. (XIX, 360; énfasis mío)

Analicemos algunas de las implicaciones de las ideas de este fragmento, de sus rasgos hipertélicos. Cuando dice: “...sé lo que han escrito los demás...” nos confirma de su recorrido por todo el logos occidental, como también de sus felices y apasionadas incursiones en las filosofías orientales y del mundo aborigen americano. Es decir, ha absorbido lo mejor que ha producido el pensamiento de estos mundos tan distantes y a la vez tan cercanos y posee una cultura universal, como cualquier gran humanista del Renacimiento. Es un hombre que vive literalmente, como el mismo ha insistido se debe 
vivir , al nivel de su tiempo porque por otro lado sabe que "ser cultos es el único modo de ser libres" (VIII, 272). De manera que pudiera haber escrito un tratado filosófico o sociológico, o jurídico, pero eso no hubiera reportado utilidad ninguna a la sociedad, por tanto, se abstiene de hacer tal cosa. Con ello pone en práctica ese sentido tan heroicamente suyo del deber y la responsabilidad para con los demás, pues sabiendo que tiene el conocimiento para hacerlo es capaz de silenciar su ego. El propio Levinas nos da testimonio de que el hombre que asume ese nivel de responsabilidad participa de un tipo de heroicidad pues ejerce dominio sobre sí mismo en beneficio de los demás. Él ser ético pone el deber por encima del derecho y del bienestar personal.

El otro libro sería estudiando su vida, su carácter, su temperamento, su sentimiento de amor al prójimo, el asunto más importante -según entiende- que hay en la vida del ser humano y única posibilidad real de redención. Ese libro tendría utilidad para sus hermanos pues les mostraría que la redención del hombre está dentro del hombre, en el conocimiento del ser, que es vía para la construcción de la verdadera humanidad que alcanza la alteridad y por tanto trasciende en el humanismo del otro, que el hombre debe reconquistarse para ser lo que es. Luego dice la frase más poética y hermosa del fragmento: "Prescindo, pues, de cuanto sé, y entro en mi Ser". Esta debe ser, sin lugar a dudas, una de las frases más radiantes de toda la escritura moderna porque se cierra al logo-centrismo, cierra el conocimiento, pone todos los libros -desde Sócrates hasta Hegel- en un cajón y sale de la biblioteca, va a leer el libro sagrado del ser, "el libro de arena", donde el infinito y la trascendencia conforman su aleph. Nótese que este Ser está escrito en mayúscula, no es el yo, no es el egos, es su esencia humana, es su dimensión sagrada lo que necesita comunicar a sus iguales. Martí sabe que si no entra en su Ser no 
podrá servir de guía, de maestro, de prócer, de héroe, de mártir, de apóstol. Sin esa exploración y ese estudio febril su palabra no podrá testificar sobre la verdad, la "vida real", la libertad, la verdadera religión que aguarda al hombre desde que perdió sus verdaderos dioses: la eticidad, que no es otra cosa que la hermandad, la fraternidad, la solidaridad que son manifestaciones naturales del hombre, formas colectivas de la ética en el seno de la comunidad.

Martí -siguiendo la huella de estas páginas que él llama Juicios donde resume su filosofia y su no filosofia-, afirma que "la naturaleza observable es la única fuente filosófica" (360). Esto es lo primero que lo acerca a Levinas, su ruptura con la tradición filosófica y su instauración del ser y la naturaleza como primera filosofía. Ahora bien, el término naturaleza en él es una entidad compleja que no se limita, exclusivamente, ni al mundo material, ni al mundo espiritual, sino que es el resultado de una interrelación armónica de ambas dimensiones y lo que resulta de esa relación. Entiende que hay dos clases de seres: los del mundo físico observable, que se puede tocar, tangible y el mundo intangible e invisible de los pensamientos y los sentimientos. Para él, lo mismo que hay leyes en un astro y en un río, las hay en la mente y que entender ambas dimensiones es lo importante, pues la una sin la otra no dará más que una verdad a medias. El mundo intangible lo considera la metafísica, y en esto coincide con Levinas.

Martí otorga más valor a la intuición de la poesía que a la experimentación de la ciencia o la filosofía. Luego de analizar las dimensiones religiosas, científicas y filosóficas y decir como todas han fallado en proporcionar las respuestas a las preguntas más álgidas de la existencia, dice: "acerquémonos a la gran Madre; abramos el gran libro, cuyas páginas han escrito los siglos, cuyos actos y hechos son océanos, cuyo 
conocimiento augusto se pierde en lo intangible e invisible" (VII, 361). En concusión, lo que el poeta pide es cerrar el libro de la razón y reabrir el de la naturaleza. Porque ese es "el error de la escuela física, que en sus extravagancias ha llegado a negar todo fenómeno espiritual" (362). Insisto en la idea de que hay que tener una manera muy revolucionaria e independiente de pensar para criticar, por un lado el discurso filosófico -como hemos visto antes- y el discurso científico nada menos que en la física, la ciencia madre. Ambos constituyen los discursos fundamentales de la Ilustración. Ahí está la base de su adelanto de algunas de las corrientes del pensamiento contemporáneo. Con relación al uso de la fuerza Martí dice que él no afirmaría que los "móviles morales, -voluntad, dignidad, orgullo patrio, educación,-- son superiores a los medios materiales [...] si no fuese de esta verdad ejemplo vivo" (362). O sea, que los principios éticos producen más bienestar que los del poder y la riqueza que son expresiones de la razón y complacen más al ego del hombre. En tanto que busca las respuestas que quiere dar a sus prójimos, él mismo se pregunta retóricamente a quién debemos preguntar: "¿A Dios?- ¡Ay! No responde porque nos han enseñado a creer en un Dios verdadero" (363) “ ¿A la fe?- ¡Ay! No basta. En nombre de la fe se ha mentido mucho" (363). Luego concluye que no se puede tener fe en esa "ciega" que ha arrojado en la hoguera a los visionarios, que le ha enseñado los instrumentos de tortura a los sabios, que ha silenciado a los profetas, ésa no dice la verdad, sino "la voz interior y natural, la primera voz que los pueblos primitivos oyeron, y el hombre de siempre oye" (363; énfasis mío), la voz del Ser. Opone a la voz de la razón, violenta, intolerante, fragmentada, la voz del Ser, equilibrada, armónica.

¿A quién preguntamos, pues? A la naturaleza. Cierro entonces esta primera instancia martiana de su no filosofía con la misma certeza con que él la abrió. ¿Dónde 
están todas las respuestas del hombre? Están en las páginas del ser en la naturaleza que es el verdadero ser, a la sombra del árbol. "Empieza el hombre en fuego y para en ala"5. Porque el buen método filosófico sería -que no ha sido- aquel que "al juzgar al hombre, lo toma en todas las manifestaciones de su ser" el que no desdeña su esencia aunque sea esto difícil y enmarañado de observar. "Debilidad científica, filosófico raquitismo, censurable anemia voluntaria de todos esos, en la forma severos y marmóreos, y en el fondo incompletos y arenosos sistemas de accidentes" (365; énfasis míos). Los sistemas que tratan de, en vez de completar al hombre, deshumanizarlo, reciben de él una severa crítica con adjetivos que en él son toda una institución (y merecen un estudio), adjetivos que siendo severos, no dejan de ser originales pues sorprende al lector con estas combinaciones de términos que con frecuencia no asociaríamos con sus nombres. Hay algo de fina ironía en ellos, como de quien se sabe curado y de vuelta de esas colinas infladas. Esto dice claramente lo que creía de los sistemas filosóficos.

\section{La estética de la existencia en Martí y Foucault}

¿Dónde comienza la escritura ética martiana? ¿Cuál puede señalarse como primer eslabón de la cadena significante de su metafísica que impugna el pensamiento de su época y con la cual conforma un paradigma? Ese situar la ética en el centro de su análisis epistémico de la sociedad y la cultura de su tiempo, pero sobre todo, de la subjetividad humana, manifiesta su primera epifanía en el Prólogo al poema del Niágara. El análisis integral que realiza en esta pieza de los fundamentales discursos de la modernidad, junto a la valoración del estado espiritual general de la sociedad en todas sus posibles 
dimensiones es lo que le otorga carácter arquetípico a ese pequeño ensayo éticofilosófico, o-quizás- onto-poético. Uno de los fragmentos más importantes del texto se ocupa de la urgente necesidad que tiene el hombre moderno de construirse una nueva subjetividad que le permita superar la crisis existencial que vive la sociedad. La angustia que padece, después que se ha venido abajo el viejo edificio de creencias y doctrinas levantadas y alimentadas - muchas veces en las llamas- por veinte siglos de tradición judeo-cristiana, lo ha dejado en una profunda orfandad espiritual. Esta propuesta subjetividad martiana es muy revolucionaria para su época y su constitución desafía todo el andamiaje intelectual de las meta-narrativas del discurso moderno. Es una critica radical del cogito cartesiano y como tal se funda en un sujeto ético por encima de la moral cristiana, algo que sólo había sido pensado por la filosofía ética de Spinoza en el siglo XVII y que no volverá a resurgir sino hasta la segunda mitad del siglo XX. El sujeto que Martí propone está liberado de las doctrinas del discurso religioso institucional, del discurso político, del discurso jurídico y del discurso científico, ejes fundamentales del aparato hegemónico del estado moderno.

Este primer eslabón de la constitución de la subjetividad ética martiana hunde sus raíces en un pasado lejano. Por una parte va a buscar ciertas esencias de la tradición pagana y el cristianismo más antiguo, y por la otra bebe en las la tradición oriental y la greco-latina, sobre todo del pensamiento estoico. En general la sociedad griega hasta su absorción por el naciente Imperio Romano practicaba "el cuidado de sí", procuraba vivir una vida dentro de los cánones del equilibrio y la armonía del ser y la naturaleza, una vida que fuera en lo posible hermosa, digna de ser contada, una especie de estética de la existencia. En esta confluencia se encuentran el pensamiento de Martí y de Foucault. 
Michel Foucault, uno de los grandes filósofos del siglo XX, también controversial, a veces inclasificable y muy poco ortodoxo de sus investigaciones, después de producir uno de los más lúcidos, extensos y provocadores análisis sobre las estructuras constitutivas del aparato de poder del estado moderno; después de haber indagado acerca de la evolución de las formas del pensamiento en las diferentes épocas de la historia, al final de su vida, vuelve todo su interés hacia el gran tema de la filosofía desde su nacimiento en Grecia: la formación de la subjetividad. Foucault entiende que el sujeto moderno es víctima de una restricción cada vez mayor de su humanidad y que la expresión de su libertad sufre constantes mutilaciones, consecuencia de los controles y la expansión de los poderes hegemónicos del aparato político que lo (des)gobierna. Por eso el epílogo de su filosofía es la ética, la formación de la subjetividad y la búsqueda de la verdad. Es precisamente en la subjetividad ética donde el poeta cubano y el filósofo francés se cruzan y se estrechan la mano, sin saberlo, ni sospecharlo. La única explicación que podamos dar acerca de la sincronía del pensamiento martiano con el foucaultiano, y como veremos después con el de Levinas y Derrida, está en que la ética, siendo una expresión - como veremos que Martí la define- de las esencias humanas del hombre, cualquiera que emprenda por sí mismo la construcción de su subjetividad, arribará a las mismas conclusiones. Si de algo sirve esta hermenéutica del ser propuesta por Martí y después Foucault, Levinas y Derrida, entre otros es para convencernos una vez más que las esencias humanas están más allá y más acá de todas las construcciones racionales de los metarrelatos del poder. Parto primero de la definición del horizonte ético foucaultiano y cuáles son los elementos que entran en la constitución de su subjetividad para después compararlo con lo que Martí define como la labor urgente, 
insoslayable, del hombre moderno, "su reconquista" o su reconstitución de una subjetividad ética.

Las ideas éticas de Foucault están esparcidas fundamentalmente en dos de los tomos de Historia de la sexualidad, en sus conferencias para el College de France, en Tecnologías del yo y otros textos afines y en Estética, ética y hermenéutica, además de en numerosas entrevistas para diarios y publicaciones de todo el mundo. En la conferencia que titula "La hermenéutica del sujeto" para la referida institución educacional, encontramos algunos de sus criterios fundamentales sobre el tópico del desarrollo de la subjetividad. En ella comienza por citar a Sócrates quien se dirige a los transeúntes atenienses con ideas como ésta: "Tú te preocupas de tu riqueza, tu reputación y tu honor, pero no te preocupas por tu virtud y tu alma" $(93)^{6}$. El filósofo griego plantea que esa misión de cuidar de la salud del alma de sus conciudadanos es tarea que le fue encomendada por la deidad y que él la llevará a término hasta que se agoten todas sus fuerzas sin solicitar ningún pago a cambio porque "ese servicio a la ciudad-estado es más útil que incluso la victoria de un atleta en Olympia" (93), lo cual da testimonio de la importancia que la sociedad griega otorgaba al cuidado de sí mismo. Foucault cita $L a$ carta a Menoeceus, -texto epicúreo- para consignar lo siguiente: "Que nadie, siendo joven o viejo, se aparte del estudio de la filosofía, pues no se llega nunca, ni muy temprano, ni muy tarde, a asegurar la salud del alma" (94). A continuación explica que el cuidado del alma estaba vinculado al conocimiento de la filosofía y debía constituir un estudio de por vida. Sin embargo no fue -según él entiende- el "cuidado de sí mismo" una invención de la filosofía. En Grecia este aspecto era una especie de precepto de vida altamente valorado. "Un día preguntaron a Anaxandrides por qué sus compatriotas, los 
Espartanos, confiaban el cultivo de sus tierras a sus esclavos en vez de reservar esa labor para ellos mismos, a lo que él respondió: "Fue por no ocuparnos del cultivo de esos campos, sino de nosotros mismos, que adquirimos esos campos" (94-95). Según Foucault, antes de convertirse en un problema filosófico "el cuidado de sí mismo" era una forma de actividad practicada por los ciudadanos. El contenido de este cuidado no se limitaba a la conducta moral, lo que era bueno o no, sino que incluía un deber, una técnica y además una serie de procedimientos muy bien definidos.

Hay tres elementos representados en los textos clásicos -entre ellos el Alcibíadesrelacionados con el cuidado de sí mismo: la política, la pedagogía y el autoconocimiento. Foucault se cita a Séneca y Plutarco quienes aconsejan el "cuidado de sí", no sólo a los adolescentes y jóvenes preocupados por la riqueza y la fama, sino también a los hombres maduros, quienes ocupan cargos políticos o jurídicos dentro de la ciudad. Su objetivo es que éstos no abandonen esta formación y menciona a Epictetus quien urge sobre todo a los políticos para que pongan la más esmerada atención en su cuidado personal porque así estarán mejor preparados para el cuidado de los ciudadanos. En lo que concierne a la pedagogía en el Alcibiades, el "cuidado de sí mismo" era esencial debido a las deficiencias del sistema educativo y Foucault los agrupa en tres funciones importantes: la de reeducarse, la de constante batalla (para el desarrollo de una voluntad de auto-perfeccionamiento) y la curativa o terapéutica. La primera función de esta hermenéutica descansa en la necesidad de eliminar de la formación educacional todo aquello que no resulte útil. "El cuidado de sí mismo debe permitir al individuo deshacerse de los malos hábitos, de todas las falsas opiniones que uno puede asimilar de la gente, de los malos maestros, pero también de los padres y asociados" (97). Estos criterios -como 
veremos más adelante- aparecen todos en el Prólogo al poema del Niágara, como también la idea con que Foucault concluye el fragmento -muy similar a la de Martí: "Desaprender" (de-discere) es una de las importantes tareas del cultivo personal" (97). La segunda función en la práctica del enriquecimiento del ser es la lucha permanente, de modo que el individuo pueda desarrollar la tenacidad, el valor, la constancia que le sirva para vivir de acuerdo a la virtud en tiempos de paz y de guerra, es decir una herramienta personal que pueda ser útil para toda la vida. La tercera función tiene un carácter curativo y terapéutico. En este sentido Foucault recuerda un principio familiar a los epicúreos, los cínicos y los estoicos: "La tarea de la filosofía es curar las enfermedades del alma. Plutarco fue capaz un día de declarar que la filosofía y la medicina constituían mia khora, un mismo dominio" (97). El mismo Epictetus consideraba su escuela no sólo como "un lugar para la educación, sino también como una "clínica médica" [...] un "dispensario para el alma" (97).

El tercer elemento de importancia en la consecución de la formación de la subjetividad es la relación con un maestro, un preceptor, un guía espiritual. "Séneca decía que nadie era suficientemente fuerte por sí mismo para salir del estado de estulticia en que estaba. Por su parte Galo decía que el hombre se ama demasiado para ser capaz de curarse por sí mismo de sus pasiones" (98). Los griegos creían que esta guía espiritual era necesaria, no sólo en la juventud, cuando no se tiene la experiencia y herramientas necesarias para el cuidado del ser, sino que debía mantenerse a través de toda la vida hasta la vejez. Esto recuerda la frase de Martí "la educación comienza en la cuna y termina en la tumba". Entre la élite política, los estudiantes de filosofía, entre la familia, entre amigos e incluso entre maestros hay siempre consejeros privados que asisten en la 
tarea del "cuidado de sí mismo". O sea que en la civilización greco-latina esta educación de la subjetividad existe como concepción filosófica, pero además como práctica libre entre los ciudadanos, sin que intervenga ninguna regulación, código o ley sancionada por ninguna institución de la ciudad-estado, ni la intervención e imposición de ninguna dignidad religiosa. Es un ejercicio de auto-educación.

Una de las características que distingue a esta estética de la existencia de los griegos -que más tarde adoptan los romanos, a través de sus preceptores griegos- es que estaba definida por una serie de prácticas. En Grecia se otorgaba la misma importancia al "cuidado de sí" que al entrenamiento de un atleta. Como anota Séneca, Demetrio decía que "no tenemos que practicar ayunos (la ascesis filosófica resultaba sospechosa en estas figuras que apuntaban hacia la maravilla de sus abstinencias, sus ayunos, sus predicciones del futuro). Como buen luchador, debemos aprender sólo lo que nos permita defendernos de eventos inesperados" (99). Para lograrlo utilizaban los "discursos" llamados logoi, entendidos como discursos de verdad y discursos racionales [...] El equipamiento que necesitamos para enfrentar el futuro consiste en verdaderos discursos. Ellos son los que nos permiten enfrentar la realidad" (99).

En lo que se refiere a los "logoi" había divisiones entre las principales escuelas de pensamiento en cuanto a la necesidad o no del conocimiento teórico para enfrentar los sucesos de la existencia. Los epicúreos estaban de acuerdo en que "conocer los principios que gobiernan el mundo, la naturaleza de los dioses, las causas de los fenómenos, las leyes de la vida y la muerte" (99) era absolutamente necesario. Los estoicos y los cínicos estaban divididos entre los conocimientos teóricos y las prescripciones prácticas para la conducta. El segundo elemento relacionado con los "discursos" se refería al modo en que 
se debía interactuar con los mismos. Los griegos creían que era necesario poseerlos y dominarlos para en el caso de que se presentasen situaciones inesperadas poder recurrir a la sabiduría contenida en ellos y conjurar cualquier peligro. Esto implicaba más que la memoria. "Plutarco, por ejemplo, utiliza diferentes metáforas para referirse a la presencia de esos discursos en el hombre. Los compara con una medicina (pharmakon) de la que necesitamos proveernos para enfrentar las vicisitudes de la existencia" (100) e igualmente los compara con los mejores amigos siempre próximos en las más adversas situaciones. Para él "estos discursos deben estar en nosotros como el maestro cuya voz es suficiente para silenciar el gruñido de los perros" (100). De acuerdo a Séneca estos "discursos" deben ser parte de la memoria de cada uno y a través de la "meditación diaria alcanzar el punto en que estos sanos consejos se manifiesten de modo natural. En tal sentido, estas prácticas son muy similares a las del budismo de donde los griegos las absorben. Las ideas de Séneca y Plutarco se diferencian de las de Platón en el sentido de que éste aboga por que el alma se vuelva sobre sí misma y redescubra su verdadera naturaleza, mientras que aquéllos abogan por una verdad asimilada por medio del estudio y la práctica cotidiana de modo que permanezca activo como un principio de acción. De ahí que para que esto ocurra -según ellos entienden- hay que recurrir a una serie de ejercicios de memorización entre los cuales son importantes el escuchar, el escribir y el meditar.

En cuanto al primero "uno encuentra en Plutarco y en Philo de Alexandria un grupo de reglas destinadas al buen escuchar" (101) como, por ejemplo, cómo sentarse, cómo prestar atención y cómo recordar lo que se ha. escuchado. En cuanto al segundo, Foucault dice que había en este período un cultivo de la escritura personal: "tomar notas de las lecturas, conversaciones y reflexiones que uno escuchaba, o que tenía con otros; 
mantener diarios de cualquier tipo (lo que los griegos llamaban hupomnemata) que debían leerse de vez en cuando para reactivar su contenido en el lector. Por último, la meditación consistía en ejercicios de memorización con el objetivo de fijar bien lo que se había aprendido. Marcos Aurelio lo explicaba de esta manera: "para volver al interior de uno y examinar las 'riquezas' que uno ha depositado allí, se debe tener en el interior una especie de libro que uno pueda releer de vez en cuando" (101). Entre las prácticas más importantes asociadas con el cuidado del alma los griegos dedicaban especial interés "a la famosa melete thanatou -una meditación sobre la muerte o, más bien, un entrenamiento para ella- que verdaderamente no consiste en el mero recuerdo [...] de que uno está predestinado a morir" (104). Su principal función es enfatizar la idea de vivir cada día como si fuera el último. Según Foucault Séneca es, entre los estoicos, quien lleva más lejos estas prácticas: "Vayamos a dormir con placer y alegría, digamos, he vivido" (105). Es el mismo tipo de ejercicio que Marcus Aurelios estaba pensando cuando escribió que "la perfección moral requiere que uno viva cada día como si fuera el último" (105). El ejercicio permitía a sus practicantes preocuparse por cada acción emprendida diariamente con el objetivo de perfeccionarla y así tener la posibilidad de juzgar en vida el valor de cada una en sí misma. Así cada uno podía convertirse en juez de sí mismo y evaluar el progreso ético experimentado hasta el final de sus días. En este sentido, siendo cada cual juez y parte a la vez de sus acciones y contemplando cada paso dado por sí mismo, sin la participación y la evaluación de ninguna autoridad a la que se debe satisfacer, el hombre individual se convierte en el arquitecto de su propio destino y se esmera por vivir una vida virtuosa que debe mejorarse en el diario vivir, convirtiendo así estas prácticas en una verdadera y efectiva estética de la existencia. 
Un año antes de la muerte de Foucault -ocurrida como en Martí a temprana edadHubert L. Dreyfus y Paul Rabinow, sostuvieron con él una serie de conversaciones que luego publicaron bajo el titulo: Michel Foucault: Más allá del estructuralismo y la hermenéutica en el cual vuelve sobre algunas de las ideas que ya había desarrollado antes sobre la ética y la formación de la subjetividad. Aquí reitera el papel que para la cultura griega desempeñaban la lectura y la escritura en la constitución de la subjetividad, así como la idea de que la ética "no estaba relacionada con ningún sistema social to por lo menos legal- ni institucional" (263). ${ }^{7}$ Esto cambió radicalmente en el mundo cristiano, en el cual las técnicas y prácticas del cuidado de sí mismo fueron asimiladas a la institución cristiana la que modifica sus contenidos. A partir de entonces dicha hermenéutica pasa, de ser una actividad controlada por cada individuo y su voluntad, a depender de una voluntad divina asociada con las ideas de redención y salvación. Desde el instante en que el "cuidado de sí mismo" fue tarea de Dios, el hombre comenzó a perder el arsenal de recursos y técnicas que habían sido desarrolladas a tales efectos y, en consecuencia, las riendas de su subjetividad son concedidas a una figura superdotada, es decir, transfiere la ontología de su ser a un super-ser. Este rol lo asumirá más tarde el Estado moderno. A Foucault le resulta muy interesante -es una idea que reitera- que la ética en Grecia no haya estado determinada por el poder político, ni tampoco por el aparato jurídico, como sí sucede a partir de la Ilustración. Del mismo modo le llama la atención que el arte en nuestra época "se haya convertido en algo que sólo se relaciona con otros objetos y no con los individuos o con la vida. Tal arte es algo especializado o producido por expertos que son artistas. ¿Pero podría alguien convertir su vida en una obra de arte?” (269). Foucault concluye que "tenemos que crearnos a nosotros mismos como obras de arte" 
(270), algo que él encuentra en La Gaya Ciencia de Nietzsche, uno de sus filósofos preferidos a quien ubicaba, junto a Marx y Freud entre los pensadores más importantes del siglo XIX.

Veamos ahora las propuestas martianas en relación con la formación de la subjetividad y cómo estas ideas constituyen la base de todo el edificio de su eticidad. Son el resultado de un largo proceso de meditación y de síntesis que cristaliza en 1882 cuando escribe este texto fundamental de la modernidad que es su Prólogo al poema del Niágara, cuyo inicio son estas dos palabras en mayúscula: ¡PASAJERO, DETENTE! Para él el hombre moderno es un viajero en constante ir y venir hacia todas partes. Todo está en constante movimiento, nada permanece, nada está estático. El reposo, el sosiego, la meditación, la contemplación; todo eso ha sido devorado por las llamas de la locomotora que avanza indetenible hacia el futuro del "progreso". Por eso él ve a los hombres en una carrera desaforada detrás de la riqueza material para "vivir todo dorado; sin ver que la naturaleza humana no ha de cambiar de cómo es, y con sacar el oro afuera, no se hace sino quedarse sin oro alguno adentro" (VII, 223). Por otro lado el amor, ese sentimiento que hace humano todo lo que toca anda diluido o extraviado en el exceso de individualismo, que exacerba el narcisismo y el egoísmo y las personas ya no se tienen confianza, por lo que van desapareciendo, poco a poco, las expresiones corporales de afectividad que le son naturales. Todo el mundo lleva prisa y anda sumergido en su propio asunto, en su propio negocio; nadie tiene tiempo para detenerse a abrazar al prójimo. Al poeta le sorprende sobremanera una sociedad donde se evaden los unos a los otros y hasta se evaden de sí mismos y los necesitados y menesterosos en la calle son un estorbo. Esta ausencia de empatía y cordialidad le parece a Martí el primer síntoma de la 
enfermedad de ese cuerpo que analiza. El amor, esencial para el equilibrio y la armonía de la vida, se ha sustituido por la búsqueda y el cultivo de la riqueza material.

El segundo síntoma de la enfermedad es el desplazamiento de los creadores del Pharmakon espiritual, de los poetas, esos sacerdotes de la palabra y tejedores de sueños, de la posición privilegiada que ha gozado en la escala social. Ahora es uno más en la masa atormentada que anda en la brega cotidiana en busca del pan de cada día, "ahora el poeta ha mudado de labor, y anda ahogando águilas" (224). Martí ve que en la acelerada lidia por la subsistencia es difícil, en medio del polvo del combate, ver el camino por donde ha de transitar el hombre moderno porque "los ruidos de la batalla apagan las melodiosas profecías de la buena ventura de tiempos venideros" (224) que es, precisamente, el pharmakon del poeta. "Ni líricos, ni épicos pueden ser hoy con naturalidad y sosiego los poetas; ni cabe más lírica que la que saca uno de sí propio" (225). Es decir, el buscar dentro de sí, el mirar dentro, el cuidado de sí se impone puesto que "nadie tiene hoy la fe segura. Los mismos que lo creen, se engañan" (225). El cielo inconmovible, seguro refugio de otros tiempos, se ha desplomado sobre los hombres que, ocupados como han estado en la búsqueda del oro, no han cuidado de sí mismos, no se han apropiado de los discursos de que hablaban Platón, Plutarco y Séneca para tener con que defenderse en los tiempos de inesperadas vicisitudes de la existencia.

El tercer síntoma que diagnostica Martí es el del cambio incesante de ideas que "se maduran en la plaza en que se enseñan, y andando de mano en mano y de pie en pie" (227) no se asientan en las mentes por mucho tiempo como antes. "Nacen a caballo, montadas en relámpagos, con alas" [...] Las estrujan, las ponen en alto, se las ciñen como coronas, las clavan en picota, las erigen en ídolo, las vuelcan, las mantean" (227). No hay 
tiempo para sopesar las ideas, para irles a su raíz. En lo que tardan en aparecer y desaparecer, no hay tiempo de conocerlas. "Las imágenes se devoran en la mente. No alcanza el tiempo para dar forma a lo que se piensa" (227). Hoy las ideas "se salen en tropel de los labios, como semillas de oro, que caen en suelo hirviente; se quiebran, se radifican, se evaporan, se malogran -joh, hermoso sacrificio!- para quien las crea; se deshacen en chispas encendidas; se desmigajan" (227). En ese torbellino de incesante cambio $\sin$ fin, nada se fija, porque lo que se crea hoy a la mañana siguiente ha envejecido. El culto a lo novedoso es la religión de la modernidad porque el pasado es lo fijo, lo que no se mueve, lo inerte, sus vueltas cesaron y por tanto es inservible. Hay que sepultarlo sin ceremonia porque su cadáver apesta. El poeta se lamenta de tanta energía y creatividad desperdiciada, en la marcha incesante hacia el futuro luminoso, sin sospechar que el desecho será otra de las grandes conquistas del "progreso" del mundo moderno.

Ante este paisaje desolador, el poeta vuelve los ojos a la naturaleza donde encuentra la verdadera poesía. "Cuando la vida se asiente, surgirá el Dante venidero [...] Hoy Dante vive en sí, y de sí" (229). Martí nos resume su diagnóstico aludiendo a los cambios sustanciales que la vida del hombre ha experimentado en el orden histórico, social, espiritual y cultural y concluye que "la vida íntima $[\ldots]$ ha venido a ser el asunto principal y, con la naturaleza, el único asunto legítimo de la poesía moderna" (229). No obstante sabe que el entrar en sí para el ser moderno es una tarea titánica en un mundo que desciende sobre él con una violencia inusitada, con una avalancha abrumadora de discursos que lo atan, lo descentran espiritualmente y lo:dejan en una segunda orfandad. "El hombre, apenas entra en el goce de la razón que desde su cuna le oscurecen, tiene que deshacerse para entrar verdaderamente en sí. Es un braceo hercúleo contra los obstáculos 
que le alza al paso su propia naturaleza" (229), junto al caudal de ideas perniciosas, convencionales y falaces con que lo alimentan o envenenan sus mayores y la educación de su sociedad. Hace la distinción entre la vida falsa, adquirida en esa marea incesante de falsedades y la vida espontánea y pre-natural, ese espacio que Kristeva, en su teoría semanalítica sobre la formación de la subjetividad denomina el espacio de la jorá. ${ }^{8}$ Lo que Martí plantea es que interrumpen al hombre con el falso pretexto de completarlo. Esta idea es vital pues encierra, no sólo una crítica al discurso racional, sino a las instituciones educativas prohijadas por la Ilustración. "No bien nace, ya están en pie, junto a su cuna con grandes y fuertes vendas preparadas en las manos, las filosofías, las religiones, las pasiones de los padres, los sistemas políticos. Y lo atan; y lo enfajan; y el hombre es ya, por toda su vida en la tierra, un caballo embridado" (230). De esta manera el poeta cubano ve que ahora es "la tierra una vasta morada de enmascarados" (230). Este cuerpo enfermo requiere una especie de cirugía similar a la que veía Marcus Aurelius cuando comparaba los discursos para el "cuidado de sí" con los instrumentos de un cirujano, como nos dice Foucault en "La hermenéutica del sujeto". Para Martí está claro que ninguno de esos discursos -ni el filosófico, ni el político, ni el jurídico, ni el religioso- dan al hombre el alimento necesario para desarrollar su ser individual en el equilibrio, la armonía y la belleza que le son necesarias para alcanzar a modelar esa estética de la existencia que podría llenar su humanidad del verdadero contenido que le es esencial. Aquí arranca, precisamente, lo que constituye el principio vital de su hermenéutica de la subjetividad, de la creación del sujeto para la ética.

Asegurar el albedrío humano; dejar a los espíritus su seductora forma propia; no deslucir con la imposición de ajenos prejuicios las naturalezas 
vírgenes; ponerlas en aptitud de tomar por sí lo útil, sin ofuscarlas, ni

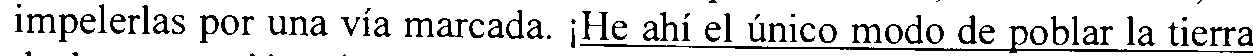
de la generación vigorosa y creadora que le falta! Las redenciones han venido siendo teóricas y formales: es necesario que sean efectivas y esenciales. Ni la originalidad literaria cabe, ni la libertad política subsiste mientras no se asegure la libertad espiritual. (230; énfasis mío)

Para Martí, entonces, la cura es -como antes para los griegos- el Pharmakon, o sea, la formación a través de la lectura, la escritura y la meditación de una subjetividad resistente a la contaminación de los virus del progreso y la modernidad, del historicismo teleológico, del cientificismo positivista, de las escatologías milenaristas y de la colonización de los espacios de su cuerpo y de su alma. Lo primero que se debe acometer como prophylassein es dejar que los espíritus libremente desarrollen su naturaleza en la naturaleza, creando las condiciones para que germinen en terreno fértil y no imponerles una parcela colonizada, plagada de ideas falaces que empobrecen y aprisionan el espíritu humano y vacían al hombre de su ética natural y de su divinidad interior. Por eso expresa con cierto visible desconcierto que esta avalancha de discursos contaminados de todo género de falsedades ha diezmado en la tierra la especie de hombres creadores, dueños de sí mismos, tan útiles en cualquier sociedad si se asegura el albedrío humano. Para él, desde que la razón tomó el liderazgo del pensamiento y expulsó a los dioses de la naturaleza, imponiendo uno distinto de su propia naturaleza y superior a ella; desde que el estado se erigió en protector y dispensador de las necesidades esenciales de la sociedad, no ha habido verdadera redención para el hombre, ni libertad auténtica, ni paz interior. Así no puede florecer literatura original y, mucho menos libertad política. Estos criterios son de primera importancia en su contra-discurso 
moderno y en la creación de su subjetividad ética. Las ideas aquí expuestas continúan con otro fragmento hipertélico

El primer trabajo del hombre es reconquistarse. Urge devolver los hombres a sí mismos; urge sacarlos del mal gobierno de la convención que sofoca o envenena sus sentimientos, acelera el despertar de sus sentidos, y recarga su inteligencia con un caudal pernicioso, ajeno, frío y falso. Sólo lo genuino es fructífero. Sólo lo directo es poderoso. Lo que otro nos lega es como manjar recalentado. Toca a cada hombre reconstruir la vida: a poco que mire en sí, la reconstruye. (230; énfasis mío)

La primera frase del fragmento nos remite directamente a la idea esencial de la hermenéutica del sujeto en Grecia que explicamos con Foucault. Martí toca la idea clave de que hay que reeducarse debido a las deficiencias del sistema educativo que "recarga la inteligencia con un caudal pernicioso, ajeno, frío y falso" Luego, el "desaprender" (dediscere) que, según Foucault estimulaban los preceptores y filósofos griegos como función profiláctica para eliminar de la educación todo aquello que no resultaba útil, es exactamente lo que Martí reclama del hombre moderno como tarea nada menos que "urgente". Él lo llama "reconquistarse", salirse del mal gobierno, devolverse a sí mismos. Ahora este "reconquistarse" de Martí va más allá del ideal griego en el sentido de que aquí está implícita la idea del "hombre natural", más allá de la polis, de la civitas. De modo que este reclamo martiano va en dos direcciones fundamentales: primero en la de constituir la subjetividad del hombre de modo natural, sin interrupción, ni desviaciones perniciosas y segundo, y más importante, la constitución de un sujeto descolonizado, liberado de los meta-discursos que la modernidad burguesa - con su herencia judeocristiana- le ha impuesto, limitando su dignidad y su eticidad. Según él si el hombre mira en sí, reconstruye su vida, es decir todos los materiales que necesita están en su 
mundo interior, no en ninguna divinidad dispensadora de bien y virtud. Hay cierta convergencia o sincronía entre las ideas de los filósofos griegos y las de Martí. Sin embargo las del poeta cubano incluyen el tópico colonial y hay que anotar también que en uno de sus apuntes de 1881, un año anterior al documento que analizamos, escribe: "Yo nací de mí mismo, y de mí mismo brotó a mis ojos, que lo calentaban como soles, el árbol del mundo" (XXI, 167). O sea, más allá del conocimiento que pueda haber tenido de estas prácticas griegas, hay un componente muy martiano en ellas. De acuerdo a Vitier "El ver en sí, el ser por sí, el venir de sí, son las constantes básicas del pensamiento y la expresión martianos en dos dimensiones conexas: su concepción del hombre y su concepción de América, perfiladas ambas desde los años que vivió en México y Guatemala"9. La incorporación de América y del hombre natural de su continente mestizo agrega a su ontología algo que no estaba en el horizonte, ni del racionalismo cartesiano, ni del historicismo hegeliano. Lo que el poeta cubano dice al hombre es que los materiales para constituir su libertad y su dignidad no están en ninguna iglesia, ni en sus jerarquías doctrinarias autoridad, sino que él es el único y verdadero agente de su auténtica liberación.

En la conclusión del fragmento anterior Martí toca uno de los componentes más importantes de su eticidad, de la obra de arte en la que él convierte su vida, que luego recrea en su escritura: el amor. "Asesino alevoso, ingrato a Dios y enemigo de los hombres, es el que, so pretexto de dirigir las generaciones nuevas, les enseña un cúmulo asilado y absoluto de doctrinas, y les predica al oído, antes que la dulce plática del amor, el evangelio bárbaro del odio" (230; énfasis mío). Para empezar hay un contra-discurso religioso dirigido directamente a esos representantes de la iglesia que predican, en 
nombre de Dios, lo que ha sido predicado por dos milenios: el temor, la idea del pecado, el odio de razas y credos, el premio del cielo y el castigo del infierno, todas ideas contrarias a la esencia humana del hombre. "Porque para él, -como nos recuerda Vitierlo que el hombre mira y halla en sí cuando se ha liberado de la cadena del odio, del causalismo circular de la imposición y la esclavitud, es precisamente el amor: tal fue su experiencia definitiva en el infierno del presidio político". ${ }^{10} \mathrm{Y}$ culmina diciendo el crítico cubano:

El amor es lo original, por lo tanto lo unitivo y lo libre, y por tanto lo justo. El amor es la justicia y sólo el amor pude verla: 'El amor es quien ve'. De ahí que el principio impositivo y represivo de autoridad que impide el conocimiento (sabiduría), impide también la justicia (el "derecho"). ${ }^{11}$

De modo que si resumiéramos este primer segmento de la eticidad martiana tendríamos presentes la reeducación del hombre, la reconquista de su ser, -que implica la construcción de un sujeto descolonizado-, la actuación por y desde el amor y la búsqueda de la belleza en la naturaleza que es la fuente del equilibrio y la justicia. Hay un arco que se tiende desde la hermenéutica del ser, del cuidado de sí, que libera al hombre y lo sitúa en su dimensión humana, hasta la búsqueda de la belleza y la justicia que hay en la naturaleza para completar el círculo de esa obra de arte que es el hombre capaz de constituir por sí propio la estética de su existencia, de convertirse en un ser ético, de vivir poéticamente. Ahora, ese humanismo al que me refiero hay que entenderlo en el sentido de su esencia primera, distanciado del humanismo euro-céntrico racista y elitista. Más bien hay que situarlo en la órbita del humanismo ético de Martí que explicaremos adelante y que implica un ser descolonizado, con lo cual, en vez del odio que se fomenta 
en el hombre para dividirlo, se fomenta el amor que es su lengua universal. Y si bien la estética de la existencia de Foucault modelada a partir del estoicismo, el epicureismo y la filosofía griega encuentra una singular convergencia en el ideario martiano de la "reconquista del ser" o del "vivir poéticamente", hay en la hermenéutica foucaultiana cierto límite dentro del logo-centrismo filosófico occidental que Martí transgrede y desborda a través de la poesía, como vimos en nuestro segundo capítulo.

\section{La ética como primera filosofía: Martí, Levinas y Derrida.}

Al hablar de la ética a propósito de Levinas ${ }^{12}$ o Derrida las referencias a la moral filosófica clásica o tradicional, se dan como crítica y no como marco referencial. ${ }^{13}$ Para Levinas es la ética la que permite que se realice la esencia crítica del saber, idea que describe con precisión lo que hace Martí con su escritura ética. Para estos dos pensadores hay una distinción clara entre los códigos rígidos de la moral cristiana y la ética, que ellos despojan de todos los contenidos racionales que la sociedad moderna ha vertido en ella. Por eso Derrida plantea que hay que llamar a la obra de Levinas una ética de la ética o una ultra-ética. Mi propósito es explicar los criterios fundamentales de la filosofía ética de Levinas y Derrida y de la convergencia que se produce entre ellos para luego establecer el punto de encuentro con el pensamiento martiano vertido en su escritura ética. Para conducir el análisis de la escritura ética martiana utilizo, fundamental, aunque no exclusivamente, el acercamiento que Simon Critchley hace de ambos filósofos en The Ethics of Deconstruction: Derrida and Levinas, la obra del propio Levinas, centrándome en Totalidad e infinito, Ética e infinito y Humanismo del otro hombre y en el homenaje 
que Derrida brinda a Levinas en Adieu to Emmanuel Levinas. Para Derrida, Totalidad e infinito es la obra maestra de Levinas porque "presupone una revolución, no sólo en la fenomenología, sino con relación a toda la historia de la filosofía europea, desde Parménides hasta Heidegger. Incluso contiene una crítica de toda la civilización occidental, marcada por el espíritu de la filosofía griega". ${ }^{14}$ Según Levinas hay un deseo de totalización en todo el pensamiento occidental, una voluntad de "reducir el universo a una originaria y última unidad a través de una mirada panorámica de síntesis dialéctica". ${ }^{15}$ La crítica levinasiana no es un evento aislado, sino que se remonta a las fuentes talmúdicas y la Biblia y al pensamiento platónico. "Contra el totalitarismo occidental, Levinas mantiene que lo humano y lo Otro divino no pueden ser reducidos a una totalidad de la cual ellos sólo serán elementos". ${ }^{16}$

Para hacer justicia a un filósofo que como Levinas, ha producido una de las más incontrovertibles revoluciones en el pensar ético occidental contemporáneo, dejemos que sea presentado -aunque sea brevemente- a través de las palabras que su amigo, Jacques Derrida, pronunciara como despedida a su muerte, ocurrida en 1995. Éstas, junto a una conferencia ofrecida al cumplirse un aniversario de su desaparición física, conforman el libro homenaje Adieu to Emmanuel Levinas. ${ }^{17}$ Derrida plantea que a través de las múltiples publicaciones, traducciones, cursos, seminarios y conferencias que sobre la obra de Levinas se han dado y se dan por todo el mundo se puede verificar que las "reverberaciones de este pensamiento ha cambiado el curso de la reflexión filosófica en nuestro tiempo y de nuestro pensar filosófico" $(4)^{18}$ en cuanto a la ética se refiere, una ética "anterior y más allá de la ontología" (4). Al referirse a Totalidad e infinito Derrida afirma que: 
...la filosofía en nuestro tiempo nunca ha hablado de una manera más sobria, cuestionando nuestro modo de pensar y aún nuestra simplista reverencia por la ontología. Es un llamado a aceptar la responsabilidad de lo que la filosofía realmente es, dándole la bienvenida, con toda la radiante e infinita exigencia que le corresponde, a la idea del Otro, es decir, la relación con autrui. Es como si se produjera un nuevo comienzo para la filosofía y un salto que ella y nosotros mismos tenemos urgencia de llevar a cabo. (9)

"Creo que cuando Levinas habla de ética -y no diría que esto no tenga nada en común con lo que ha sido considerado por ética desde Grecia hasta la filosofía alemana del XIX, ética es el otro sagrado, sin embargo, es la misma palabra" ${ }^{\text {"19 }}$. Según Critchley, Levinas fue capaz de encontrar en esta palabra, a pesar de los contenidos impropios vertidos en ella a través de toda la tradición greco-alemana, nuevas posibilidades o condiciones ocultas. De ahí que Derrrida piense que con Levinas "la palabra ética sufre una transformación semántica" (17). El mismo Levinas en un debate filosófico en París se encarga de precisar el uso que hace del término en su escritura. "He recurrido a su corrupción claramente temiendo las resonancias moralistas que contiene lo cual arriesga la absorción de su significado principal" (17) y lo esencial que pone en ella es la ineludible responsabilidad con el "otro sagrado". Su hazaña consiste en haber desracionalizado el contenido en ella vertido por la filosofía y la teología occidental y haberle devuelto resonancias humanas y poéticas. En este mismo sentido utilizo yo el término ético para la escritura martiana, desligado de la moralidad que el discurso teológico depositó en él por milenios. Derrida reconoce tener una gran deuda con el pensamiento de Levinas. "Cada vez que leo o releo a Emmanuel Levinas, me siento invadido de gratitud y admiración" (9) y afirma que no cesará de volver a su filosofía 
como una manera no olvidar el deber sagrado del filosofar, "que nos obliga a no inclinar o torcer el espacio del pensamiento por respeto al otro" (10), de cuya relación nace la justicia. Con respecto al lenguaje Derrida explica cómo Levinas considera que su esencia es la bondad, la amistad y la hospitalidad, tres conceptos claves de su ética que lo acercan a Martí.

Emmanuel Levinas concibe la ética como la primera filosofía, pero su punto de partida no está en la filosofía griega, ni en la filosofía clásica alemana. Es decir, el filósofo lituano-francés da un salto que pasa por encima del cogito cartesiano para elaborar una ontología que disiente en su contenido de la subjetividad racional occidental centrada en el yo, encerrada en su identidad y, por tanto, imposibilitada de alcanzar la alteridad en su más radiante iluminación. Y más radical aún, sitúa lo esencial de su ética más allá de la ontología de la filosofía occidental. Ese es su gran salto mortal, donde retuerce la tuerca hasta hacer estallar los cimientos estratificados del pensar trascendente en la óptica filosófica tradicional. La subjetividad racional ha sido la causa del surgimiento del egoísmo, el hedonismo y el solipsismo que han caracterizado, según Levinas, a la civilización occidental desde sus orígenes. Su ética asesta un duro golpe al humanismo clásico, ese humanismo centrado en un sujeto egocéntrico que ha condicionado el pensamiento de la humanidad por los últimos veinte siglos y que ha producido el aniquilamiento de sujetos y culturas diversas y heterogéneas.

El fundamento de la filosofía levinasiana es una subjetividad que se realiza en el acto ético de reconocimiento y acogida del Otro. Este reconocimiento del Otro es la vía para la trascendencia. El ser que propone Levinas es uno cuya humanidad es distinta porque la primacía la tiene el humanismo del Otro hombre. Este humanismo del Otro se 
"sustenta en la subjetividad que se instaura en el momento en que el yo, al ser proyectado hacia el exterior por la intencionalidad, no regresa a sí mismo, sino que se abre a la alteridad, mediante el reconocimiento del otro, a quien acoge como huésped"20. Al estudiar el planteamiento de la constitución de la subjetividad en la filosofía occidental concluye que el problema ha estado en el abordaje de este fenómeno desde la perspectiva del conocimiento, olvidando su verdadera condición ontológica. Hay en toda su filosofía una radical crítica al racionalismo entronizado por la modernidad como la condición excepcional del hombre.

Sin embargo -como aludimos al inicio- lo revolucionario del pensar de Levinas lo lleva más allá de la ontología porque ésta no respeta la alteridad. Por tanto él reconoce una diferencia entre ontología y metafísica. En Totalidad e infinito (1987), presenta argumentos epistemológicos para probar que la metafísica -como trascendencia-precede a la ontología porque reconoce que ésta, como acto de conocimiento "reduce el ser al Mismo, lo atrapa, lo posee", de ahí que "la considere como una filosofia del poder, de la injusticia". ${ }^{21}$ Levinas establece una diferencia entre el conocimiento -que priva al ser de su alteridad- con respecto de su dimensión metafísica. "Considera que la ontología es la teoría como inteligencia de los seres y por ello renuncia al deseo metafísico, ya que retorna lo Otro a lo Mismo, mientras que la metafísica es la teoría como respeto a la exterioridad". ${ }^{22}$ Es la ética la que permite que se realice la esencia crítica del saber como relación de alteridad con el ser. Por su parte Simon Critchley considera que la crítica es el modo de ser por excelencia de la ética levinasiana y que ésta se da como "mise en question de la libertad, espontaneidad y la aventurera, empresa del conocimiento del egos que persigue reducir toda expresión de otredad a lo mismo"23. Para Levinas, entonces, lo 
ético es "la localización de un punto de alteridad, o lo que [...] llama 'exterioridad" (extériorité) que no puede ser reducida a lo Mismo. Por lo que [...] conciencia moral no es una experiencia de valores, sino el acceso al ser exterior" (5). Esta exterioridad para Levinas asume la imagen de un rostro (visage) y lo define como "el modo en el cual lo otro se presenta él mismo, excediendo la idea de lo otro en mí" (5). Ese rostro que es el otro ser humano, según entiende Levinas, no se puede "evadir, comprender o matar y ante quien yo soy llamado a justicia, para justificarme a mí mismo" (5).

De modo que Levinas $-\mathrm{y}$ en esto se nos acerca a Martí- aboga por una no

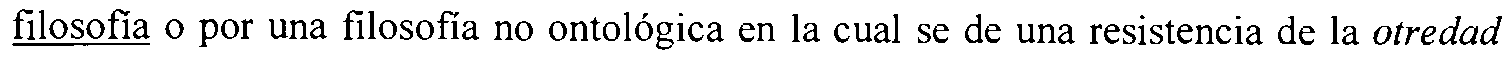
hacia lo Mismo. "Y es esta resistencia, este punto de exterioridad del logos filosófico", donde sitúa su ética. Dicho con otras palabras "la ética levinasiana es una primera filosofía que destruye la ontología y el logo-centrismo y al hacerlo cuestiona toda la filosofía occidental desde sus inicios. En consecuencia, la pregunta fundamental para la filosofía no es el 'ser o no ser de Hamlet' [...] o la leibniziana de Heidegger ‘¿Por qué hay seres y no mejor nada?' sino más bien, 'cómo el ser se justifica a sí mismo?" (9). Incluso cuestiona algunos de los mitos que han servido como base en la elaboración de las meta-narrativas de la civilización occidental y al mito de Ulises retornando a Itaca, opone el de Abraham, quien abandona la tierra de su patria para siempre por una tierra desconocida. Es decir, Levinas va más allá de toda la filosofía -la antigua, la clásica y la contemporánea- y en palabras del propio Derrida plantea "una ética más acá y más allá de la ontología, el Estado, o la política, e incluso más allá de la ética" ${ }^{24} \mathrm{O}$ sea, va hasta la misma raíz de la idea -sugerida por la filosofía continental de entreguerras- de que la filosofia no puede ser un cuerpo abstracto de ideas, una ciencia entendida sólo por 
elegidos y por tanto divorciada de la realidad, sino un instrumento teórico-práctico que sirva para contrarrestar los excesos del poder y que ayude al hombre a reconquistar su humanidad degenerada en las ideologías. En este punto él y Martí se abrazan en su cuestionamiento de la filosofia y el discurso contra-hegemónico.

Hay otros dos aspectos importantes en su filosofía ética -donde también está Martí de cuerpo entero- que son la muerte y la trascendencia. Para él la verdadera intención de la ética es la trascendencia y su punto de partida es la preocupación existencial fundamental del hombre desde su nacimiento: la muerte. Lo primero que establece nuestro filósofo es que este acontecimiento es primordialmente emocional, contrario a la "visión del ser como en Platón" y a la "aspiración hacia la nada como en Heidegger", sino una relación "meramente emocional en la que no entra el conocimiento previo de nuestra sensibilidad y nuestro intelecto" $(4) .^{25}$ La relación que el sujeto establece en la muerte es con el misterio, según Levinas y se sabe por instinto, es decir, es pre-racional. También, contrario a Heidegger, para él la muerte abre posibilidades, no las cierra. Otro concepto importante en la filosofia levinasiana es que: La trascendencia no es una transportación [ni tampoco] un cambio de condiciones, de estado, sino que es una trans-sustanciación que se da [...] como revelamiento del Otro que instaura el discurso, el respeto, la enseñanza y en ese sentido la relación es ética" (6). En tal sentido "además de una categoría pre-ontológica, una categoría ética y asimismo una categoría de socialidad. (6) la trascendencia requiere la independencia que se da a partir de la exterioridad". En estos criterios es donde se inserta con mayor fuerza la escritura y la acción ética martianas, como veremos más adelante: la muerte como apertura a la alteridad, como respeto, como sacrificio, como entrega, como posibilidad de trascendencia en el sentido 
levinasiano, porque en la doctrinal, según Levinas, el sujeto no trasciende en tanto que lo único que hace es transportarse, y lo que ocurre es un cambio de cualidades y condiciones, pero no de sustancia pues la identidad del sujeto no se compromete. "Levinas critica la idea clásica debido a que está fundamentada en un vínculo indisoluble entre lo Uno y el ser, que es mónada, en el que el pluralismo no aparece en el existir de los existentes y, en consecuencia, como simple relación, la trascendencia es menos que el ser" (6). Pero él entiende la trascendencia -que es un acto ético- a partir de su relación con la alteridad, con el reconocimiento del otro que abre la pluralidad y es a través de esta relación del sujeto con el otro que se revive, se reproduce y logra una permanencia. "En consecuencia la trascendencia que nos propone Levinas, no implica que uno de los términos sea subsumido por el otro, sino que se mantenga la separación entre ambos, para que no se dé la totalización" (6). Esa es la única forma de resistir la unidad que es la negación de la alteridad. "Para Levinas la metafísica es la dimensión de la bondad, del deseo de lo absolutamente Otro, la defensa de la libertad, el prevenir el momento de la inhumanidad" (7), o sea, la justicia. Levinas sintetiza estas ideas en Totalidad e infinito cuando dice: "Morir por lo invisible: he ahí la metafísica" $(58),{ }^{26}$

Pero Levinas no se detiene aquí, sino que añade otras dimensiones a la constitución de su filosofía ética. Entre ellas está la dimensión del sufrimiento que tiene una carga positiva, y en este sentido, como también hace Martí, supera el nihilismo nietzscheniano y el existencialismo sartreano. La carga de sufrimiento y angustia que experimenta el hombre y que lo enfrenta a la nada adquiere una dimensión positiva si el sujeto se realiza en la alteridad, si vislumbra la muerte como alteridad en el sufrimiento que se alcanza en la exasperación de la soledad y que se convierte en el acto de darse, de 
entregarse al otro. Igualmente plantea "que es la sensibilidad y no la razón la vía para acceder a la alteridad a través de la corporalidad y su voluptuosidad. El sujeto levinasiano es eminentemente...corporal, encarnado y la corporalidad no es contingente, sino fundamental para el sujeto concreto, antes que mente el sujeto es cuerpo" (9), con lo cual asesta un duro golpe al cogito cartesiano. En consecuencia disiente de la idea de que sea la conciencia la que asigne el sentido, ya que eso es consecuencia de un sujeto cerrado en sí mismo, ni tampoco que haya una dualidad cuerpo alma, sino que se funden en un régimen ontológico. Estas ideas abren una nueva forma de entender el ser en las dimensiones del amor y la filiación. Para el filósofo lituano-francés hay un tipo de heroísmo no egoísta que se expresa cuando el sujeto abierto a la otredad experimenta el eros y participa en la fecundidad. Este es el héroe que puede trascender la muerte pues si la subjetividad se funda en el acto de darse al otro y al mismo tiempo recibirlo, esencia de la relación ética, esta relación de abrirse al exterior, saliendo del yo con un extraño en la relación erótica y filial es una verdadera forma de trascender. Ni en la conciencia, ni en el poder se funda la trascendencia. "En el eros se exalta entre seres una alteridad que no se reduce a la diferencia lógica o numérica..." (57). ${ }^{27}$ En esta relación, tuerce un tanto más la tuerca y arremete contra la idea del amor como fusión, como unión pues -dice- "lo patético del amor consiste, por el contrario, en una dualidad insuperable de los seres [...] Lo otro en tanto que otro no es aquí un objeto que pasa a ser nuestro o que pasa a ser nosotros; por el contrario, se retira en su misterio..." (58).

Es decir; ni la lógica, ni la conciencia determinan esta relación Inter-subjetiva asimétrica que no retorna a sí misma, pero que a la vez conserva su subjetividad. Por su parte la fecundidad es otra dimensión trascendente, que Levinas no limita solamente a la 
dimensión biológica, pues "se puede concebir la filialidad como relación entre seres humanos sin lazos de parentesco biológico" (61) como, por ejemplo, la que se da entre maestro y discípulo. Con relación a la paternidad plantea además algo que Martí escribe en casi exactamente igual. Es tan hermosa y rara esta sincronía que sólo la poesía puede concebirla pues es una idea no común en el debate filosófico o estético, o sea, no pertenece a los temas más debatidos. Dice Levinas: "La paternidad es una relación con un extraño que, aun siendo el otro, es yo. La relación del yo con un yo-mismo que es, sin embargo, extraño a mí [...] Yo no tengo a mi hijo, yo soy, de alguna manera, mi hijo" (62). Inserto a continuación lo que dice Martí para que se vea la asombrosa similitud de las ideas de ambos. En "Musa traviesa", poema más extenso de Ismaelillo Martí escribe: "Hijo soy de mi hijo / Él me rehace" (28). ${ }^{28}$ Debo añadir que en este libro "poeta y libro reniegan de la ética de su época y de los moldes tradicionales estéticos, sometiéndolos a una perspectiva critica de la que no se excluye el mismo autor" ${ }^{29}$ Es decir, al comparar una idea suya con otra de Martí, encontramos esta crítica en que se nos dice que Martí reniega de la ética de su época. Estamos en presencia de una serie de felices coincidencias, lo cual habla a favor de la idea de que la ética y la poesía instauran la verdad. Levinas concluye su pensamiento anterior de esta manera: "No es según la categoría de causa, sino [...] de padre como se hace la libertad y como se cumple el tiempo. [...] La paternidad no es simplemente una renovación del padre en el hijo y su confusión en él. Es también la exterioridad del padre con respecto al hijo. Es un existir pluralista" (62).

En cuanto a la responsabilidad también Levinas elabora ideas que nos explican mejor el ser martiano. Lo primero interesante es que "es en la ética, entendida como 
responsabilidad, donde se anuda el nudo mismo de lo subjetivo" (79), si se entiende esta responsabilidad abierta hacia la otredad. Para Levinas la relación con el Otro no puede ser entendida más que como responsabilidad, en el sentido del dar, del entregar y ese para él es el verdadero espíritu humano. Es decir para él la humanidad significa "un resquebrajamiento ético de la ontología y una superación de la libertad por la responsabilidad" (81). En sus palabras "se trata de decir la identidad misma del yo humano a partir de la responsabilidad [...] de esa deposición del yo soberano de la conciencia de sí [...] soy yo en la inedida en que soy responsable" (85). Y termina su explicación con unas hermosas palabras de Dostoievski: "Todos somos responsables de todo y de todos ante todos, y yo más que todos los otros" (85). A la responsabilidad vincula el sentido de lo justo y del deber y dice que "nadie puede, en ningún momento, decir: he cumplido todo mi deber...salvo el hipócrita" (88). Quiero culminar esta condensación de su pensamiento -algo difícil de lograr en tan breve espacio por la misma complejidad de su lenguaje- citando unas palabras que responden a una pregunta sobre el profetismo que él ve como un momento de la condición humana vinculado a la responsabilidad. "Hay profetismo, hay inspiración en el hombre que responde por el otro, paradójicamente antes, incluso, de saber lo que, en concreto, se exige de él. Esta responsabilidad anterior a la Ley es revelación de Dios" (95).

Para referimos a la segunda instancia de la teoría Levinasiana, corresponde ahora hablar de la Alteridad vinculada, en este caso, a la responsabilidad y el deber de salir de sí y abrirse al humanismo del otro hombre. Ya adelantamos que la responsabilidad en Martí es llevada al límite del heroísmo, es casi una religión, entendiendo este término en su sentido etimológico y humano. La argumentación inicial de esta dimensión martiana 
ocupa todo el capítulo dedicado a su "Arqueología de la tradición" en donde Martí se desplaza a la alteridad en su más radiante esplendor. Siendo este fragmento de su escritura ética el que se levanta en defensa de las voces silenciadas, desplazadas, deshumanizadas por la modernidad, voces que encuentran una representación digna y una dimensión de justicia humana en su palabra, sería suficiente para argumentar la responsabilidad altérica en Martí y justificar la afirmación de que esta dimensión en él es llevada la límite del heroísmo. No obstante intentaremos dejar hablar a Martí su lengua ética del deber donde aparece el Otro bienvenido en la hospitalidad de su palabra poética. "El deber del hombre virtuoso no está sólo en el egoísmo de cultivar la virtud en si, sino que falta a su deber el que descansa mientras no haya triunfado la virtud entre los hombres" (II, 24) lo cual resuena en el Levinas que dice: "nadie puede, en ningún momento, decir: he cumplido todo mi deber...salvo el hipócrita" citado. Porque Martí siente que no es hombre "quien no ayude a la seguridad y dicha de los demás hombres" (II, 380). Para el cubano el cumplimiento del deber, de la responsabilidad humana es más importante que el derecho. En algún lugar se ha dicho que él es un místico del deber. "Todas las desventuras del hombre comienzan en el instante en que, -disfrazado de razón humana, -el deseo obliga al hombre a separarse, -siquiera sea la separación imperceptible, - del cumplimiento heroico del deber" (XXI, 138). Después "sólo en el cumplimiento triste y áspero del deber está la verdadera gloria. Y aún ha de ser cumplido $[\ldots]$ en beneficio ajeno, porque si va en él alguna esperanza de bien propio [...] ya se empaña y pierde fuerza moral" (III, 266; énfasis mío), que también repite casi exactamente lo que dice Levinas cuando responde a la pregunta sobre el profetismo. Ese pensamiento martiano es sumamente importante porque contiene una de las claves 
esenciales de la ética levinasiana, pero además porque es una de las instancias del paradigma de su escritura ética. Levinas dice sobre el darse, que la esencia de la bondad es un alejamiento del Deseo, "puesto que se nutre, podría decirse, de su hambre" 30 , mientras Martí dice en "Cual de incensario roto" de Flores del destierro: "Me nutro del dolor que me consume. / De donde vine, ahí voy: al Universo".31

Ahora esa generosidad tiene que darse como "aventura, es decir, hacia una alteridad absoluta, imposible de anticipar, como se va hacia la muerte" ${ }^{32}$ No sé cómo clasificar esta sincronía entre el pensamiento ético de Levinas y Martí, autores desconocidos el uno para el otro, y que parecen tomar sus palabras de la misma fuente. Pero algo es cierto y es lo que mayor sorpresa me causa: que dos pensamientos coincidan de esta manera -no una vez, sino varias- en materia tan escabrosa, tan desvirtuada en sus esencias por dos mil años de falacias epistémicas y ontológicas, que se considere que lo que Levinas ha hecho es devolverle a la ética sus esencias originales, desintoxicarla de doxología, o si se quiere descolonizarla y que Martí medio siglo antes esté diciendo lo mismo. Eso tiene connotaciones que van más allá de la mera coincidencia y testimonian algo que, como mínimo, es luminoso, o numinoso, no sabría decir con exactitud. Esta especie de asombro me conduce a la pregunta: ¿Dónde colocamos a Martí? Sospecho que estas coincidencias deberán seguir siendo exploradas porque han de alumbrar otros senderos. Sobre ese fondo se cierra, se clausuran las premisas fundamentales de la filosofía moderna; a decir, el pragmatismo, el utilitarismo, el individualismo, que son los ideales que contienen la crisis misma de esta etapa de la historia. En sus antípodas, por el contrario, se abren la hospitalidad, la hermandad, la justicia y la solidaridad incondicionales que son los ideales esenciales de la ética. En esos espacios liminales, en 
esa lejanía se perfilan la fibras verdaderas del ser humano que trae la justicia, el ser para la libertad y la trascendencia en el aquí y el ahora. En "Francisco Sellén" Martí dice que "no haya gusto mayor que el de cumplir en silencio con el deber, fuera de lo cual no hay poesía cierta" (V, 181). Es decir, en el servicio al otro, el deber para con el otro, el sacrificio hacia la alteridad sin saber el destino o el beneficio que se obtendrá, está la verdadera otredad y la verdad trascendente del hombre.

En lo que se refiere a la muerte también se producen correspondencias entre el poeta cubano y el filósofo lituano-francés. Para explorar esta dimensión martiana, cabe recordar aquí la idea de Octavio Paz - que ya citamos- a propósito de su análisis del poema "Dos patrias" en el cual él ve resumido todo lo que había querido decir de la analogía en Los hijos del limo. Según entiende el crítico mexicano Martí era el único de los poetas modernistas liberado del fantasma del Dios cristiano, y por tanto del sentimiento angustioso de la muerte. Lleva toda la razón Octavio Paz en esta afirmación. La idea de la muerte en Martí -que de acuerdo a Hardt y Negri ha sido permanentemente explotada por el poder del estado moderno como un arma de control sobre el deseo y la esperanza de liberación de las masas- tiene su más digno antecedente en Spinoza. Su temperamento inquieto y su espíritu ecléctico, junto con las disonancias cognitivas que había detectado en su tradición filosófica, lo lanzan a explorar otras filosofías, otras culturas y en esa arqueología espiritual descubre la filosofia india, que "embriaga, como un bosque de azahares, y acontece con ella como con ver volar aves, que enciende ansias de volar" (XIII, 27). En esta tradición descubre que hay otras dimensiones para el ser humano que van más allá de las dualidades maniqueas de las escatologías milenaristas cristianas. Entonces entiende que la muerte no es fin, sino tránsito y que la misión del 
hombre es obrar bien y tratar de penetrar, con el estudio de la naturaleza, del espíritu y del trabajo, las complejidades del misterio de la existencia. "La muerte es una victoria, y cuando se ha vivido bien, el féretro es un carro de triunfo [...] La muerte de un justo es una fiesta, [...] Va a reposar, el que lo dio todo de sí, e hizo bien a los otros" (XIII, 17-18; énfasis mío). Este pensamiento se opone a la idea moderna de la muerte como fin, creadora del sentimiento de angustia que caracteriza el espíritu racional. De ahí que piense como los antiguos que: "Morir no es nada, morir es vivir, morir es sembrar [...] Vale, y vivirás. Sirve y vivirás. Ama y vivirás. Despídete de ti mismo y vivirás. Cae bien y te levantarás" (XXI, 370; énfasis mío).

Originales y audaces como mínimo podríamos clasificar estas ideas martianas sobre la muerte como victoria, como fiesta, como siembra, como cosecha, todas dimensiones positivas del ser humano. Estas concepciones nacen de una cosmovisión que ha entendido la relación que hay entre todo lo existente y que sabe "que todo está en todo, y lo uno explica lo otro y cuando lo que es ahora no sea, se probará a su vez por lo que esté siendo entonces [...] Tanta fortuna es morir como nacer porque los muertos están vivos" (XIII, 136, énfasis mío). Habría que decir en su favor -y cumpliendo una de las tesis de Benjamin- que él ha contribuido con su arqueología a revivir -como hace Vallejo con el soldado de "Masa" muerto en batalla- a muchos de los muertos que tuvieron la desgracia de encontrarse en el camino del colonialismo. No es común hallar este tipo de ideas en la escritura modernista. Corresponde a ese tipo de frases martianas en que se le retuerce el cuello al cisne una y mil veces. Hay que valorar otra frase como "despídete de ti mismo y vivirás" en el contexto del pragmatismo y el utilitarismo modernos para tener una idea exacta de la dimensión de su espíritu y su capacidad de ver del otro lado de las 
cosas. En "Los ruidos humanos" Martí se pregunta: "Pues ¿hay mayor ventura que morir? ¡Pues es morir más que deleitísimo premio; ansiado punto, sabroso puerto, estación nueva en viaje largo, objeto de amor al alma poética, braceo feliz del naufrago..." (XIX, 386). ¿Cómo no iba a ser un espíritu libre, nadando a contracorriente y desembarazado de todos los metarrelatos modernos quien tenía estas ideas sobre uno de los acontecimientos más agónicos de la existencia humana que ha paralizado al hombre por tantos siglos de tradición cristiana. Martí llega a decir, con otro pensamiento antimoderno que "el que no sabe despreciar la vida, no la merece" (XXII, 81). Si esto no es la absoluta antítesis del pensamiento racional y triunfalista de la sociedad moderna que sobre-valora -pero a la vez degrada- la vida y desvaloriza la muerte, yo no sé qué lo es. Son muchas más las sentencias y pensamientos martianos sobre la muerte. En capítulos anteriores referimos algunas vinculadas a la poesía. Cerremos, entonces, este punto con un pensamiento que vincula varias de las dimensiones examinadas en este capítulo: la muerte, el amor, el sacrificio, la filialidad, la naturaleza y la poesía que está en la misma forma del pensamiento. Al referirse a la obra de Whitman dice que "la muerte es cosecha" y que "un hueso es una flor" y luego concluye: "la muerte es una forma oculta de la vida [...] los hombres, al pasar, deben besarse en la mejilla; abrácense los vivos en amor inefable", ideas que repercuten en la poesía de ambos. Finalmente "el sufrimiento es menos para las almas que el amor posee; la vida no tiene dolores para el que entiende a tiempo su sentido; del mismo germen son la miel, la luz y el beso". (XIII, 134).

Cierra el fragmento con una hermosa frase metafórica que recuerda las sentencias oscuras heraclíteas, por la condensación y el simbolismo que hay en ella. De manera que él no ve diferencia entre la dimensión de la vida y de la muerte, en tanto que ambas deben 
ser conquistadas en el proceso de creación del ser, en la difícil tarea de construir la subjetividad humana en la alteridad. O sea, que ni finitud, ni destrucción, ni acabamiento, ni vacío, ni la nada son conceptos asociados con la dimensión de la muerte tal y como Martí la entiende. Todo lo contrario, para él la muerte es conquista, es sacrificio, es siembra, es cosecha, es viaje, es victoria, es triunfo, y es hermosura. Es, en resumen, el punto de rotación en el que se anula definitivamente la angustia existencial -aún en los momentos de mayor desgarramiento- que caracteriza la vida del hombre moderno. Porque concibe su vida como entrega en el sacrificio y el sufrimiento por el mejoramiento humano en el que tiene fe, y porque entiende las contradicciones aparentes y la conexión entre todo lo que existe, esta dimensión se convierte en el vehículo último de su trascendencia. Para concluir con el pensamiento anterior me gustaría hacer referencia a la frase: "abrácense los vivos en amor inefable". Quien conozca la trayectoria vital de Martí entenderá bien todas las implicaciones de esta exhortación. En el primer nivel de esta idea están los últimos quince años de su vida vividos en el crudo invierno de Nueva York, alejado de su familia, de su patria, con su matrimonio destruido, lejos de su hijo, realizando labores burocráticas para sobrevivir, trabajando en la sombra por liberar a su patria del colonialismo; en el segundo nivel está la frialdad, la distancia, el cálculo de las almas que contempla en las multitudes de las calles de la "urbe antiática", la desconfianza y dureza que observa en el trato de la gente, la ausencia de gestos afectivos. En el tercer nivel está su comprensión de lo que significa el amor y cómo está vivo en cada poro del ser humano, y es la sustancia que lo une todo, lo equilibra todo, lo sana todo. Ante este cuadro su reacción es de espanto, similar al del Ánglus Novus del cuadro de Klee. Con lo resumido hasta aquí dejamos claramente establecido que Levinas ha 
desarrollado una filosofa ética de primer rango que nos ayuda a situar el pensamiento ético martiano en la justa dimensión que le corresponde entre los pensadores contemporáneos. Sin embargo se debe destacar que Martí funda toda su ética en la poética de su escritura que es su hermenéutica predilecta. Es decir, al ser una ética no filosófica no comulga con los métodos filosóficos que él considera finitos. El poeta cubano vuelve el lenguaje a su ethos, a su morada. Por eso es más justo hablar de él no como fundador de una ultra-ética como considera Derrida que hace Levinas, sino como fundador de uria ultra-poética, algo que está más allá o más acá de la poesía. Y ese lenguaje solamente puede ser el corazón de la ética.

Veamos ahora cuál es el aporte de Derrida al ámbito de la ética -que ya nos anuncia cuando elogia la obra de Levinas- pero que va más allá, incluso, pues se constituye en una especie de hermenéutica textual que es lo más cercano a las teorías cuánticas, pero que ya han hecho su exploración en el ámbito de la escritura ${ }^{33} \mathrm{Me}$ refiero a la deconstrucción. Según Derrida "la lectura deconstructiva "debe operarse con dos textos, dos manos, dos visiones, dos maneras de escuchar (écoutes). Juntos a la vez y separadamente" ${ }^{34}$. A la pregunta de por qué en su filosofía la palabra ética no aparece frecuentemente o aparece bien avanzada su carrera, Derrida responde que tiene la misma reticencia que tenía Heidegger con el término quien opinaba que antes de la división académica del pensar filosófico en ética, lógica y física los pensadores no conocían la ética como un campo diferenciado de investigación. Pero eso no significa que pensaran de manera no ética. Por el contrario "las tragedias de Sófocles y las sentencias de Heráclito piensan la noción original de ethos aún con más fundamento que Aristóteles en su Ética" ${ }^{35}$. Heidegger se refiere a la sentencia de Heráclito ethos anthropoi daimon, que 
suele traducirse como "el carácter del hombre es su destino". Ahora bien, si recordamos lo que decíamos en el capítulo anterior con relación al carácter de Martí y como éste influye toda su actuación ética, con estas ideas podemos comprender mejor porque es imposible separar la actuación ética martiana de su escritura. Según Critchley, Heidegger interpreta el ethos como morada, residencia, el lugar donde el ser existe. Es decir el hombre habita éticamente la tierra según el pensamiento heraclíteo con el que Martí tiene puntos de encuentro, sobre todo en el pensar en sentencias. A esto hay que añadir a Holderlin cuando dice que poéticamente el hombre mora en la tierra, en uno de sus poemas, analizado precisamente por Heidegger. Aquí hay una conexión muy importante en la cual se acercan la ética y la poesía como si se integraran en un haz.

Pues bien Derrida pretende llevar estas ideas fuera del pensamiento ontoteológico en que se ha pensado toda la aventura metafísica occidental. De manera que presenta cierta resistencia al término ético. Ya vimos que cuando hablaba de Levinas decía que éste había constituido una ética de la ética. La significación de la ética como algo anterior a los procedimientos de universalización y legislación, la obligación que tengo para el otro, en la "anarquía de la generosidad" es lo que complace a Derrida porque ve en esa dimensión cómo el término excede su tradicional determinismo. El concepto que el filósofo francés elabora en su lectura deconstructiva es la clausura de la metafísica (la cloture de la métaphysique) que define, respondiendo a Levinas en su texto "Violencia y metafísica" según el comentario de Simon Critchley: "el problema de la clausura de la metafisica describe la duplicidad del momento histórico -ahora-, cuando 'nuestro' lenguaje, conceptos, instituciones y la misma filosofía muestran ambos pertenecer a una tradición metafísica y logocéntrica que está teóricamente agotada, 
mientras a la vez busca romper con esa tradición (20). La metafísica martiana, así como la levinasiana se apartan de tradicional, de la misma forma que su ética.

La concepción derrideana se inserta en el contexto de una nueva tendencia del pensamiento contemporáneo que se ha dado en declarar la muerte de muchas de muchos de los discursos del pensar occidental. Comienza a fines del siglo XIX con Nietzsche y su declaración de la muerte de Dios en Así hablaba Zaratustra ${ }^{36}$. Continúa luego con el fin de las religiones, el fin de la historia, la muerte del sujeto, etc., aunque ninguno de ellos haya desaparecido verdaderamente pues, en realidad, cuando algo muere hay que deshacerse del cadáver y estos muertos siguen sin ser sepultados. Este concepto de clausura que Derrida hereda de Heidegger describe para Critchley los límites de la modernidad. "La clausura es la doble negación: permanecer dentro de los límites de una tradición y la posibilidad de transgredir esos límites" (20). El pensamiento deconstructivo se produce en el momento de cruce del límite que divide el interior de la tradición con el exterior -que podemos llamar ética- que es a la vez una clausura. En otras palabras, la clausura es "la bisagra que articula el doble movimiento entre el logo-centrismo o la metafísica y sus otros. La ética se significa en la articulación de esta bisagra" (21). Pero el término "deconstrucción" sugiere cierta negatividad, cierto echar abajo algo que Derrida se encarga de aclarar al decir que no significa demolición. De ahí que -aclara Critchley- el término "necesita ser claramente diferenciado del análisis que presupone la reducción de las entidades a sus elementos más simples [...] la deconstrucción no es tampoco crítica en su sentido más general" (21) ni un métedo para interpretar textos y por eso "no puede ser reducida a una metodología [...] o un procedimiento técnico asimilado por académicos y susceptible de ser enseñado en instituciones educacionales" [ni mucho 
menos] "una operación lista a funcionar en un texto o institución" (21). Derrida, que tiene que explicar -tarea difícil si se tiene en cuenta los límites donde pretende llegar -qué es en realidad la deconstrucción dice que ésta no es, sino que tiene lugar, que sucede. "Tal es el enigma [en palabras de Derrida] de la deconstrucción: no puede ser definida, y por eso resiste la traducción; no es una entidad, una cosa, ni es univoca o unitaria" (22). Es, de acuerdo al filósofo saber absoluto. "Se deconstruye ella misma siempre que algo sucede" (22).

Esta explicación pudiera pecar de cierta abstracción, pero consuela saber que "siempre está comprometida en la lectura de un texto" (22). Ahora, estas lecturas derrideanas tienen la particularidad de que son "parasitarias, porque son intensas lecturas de textos que derivan su sustento de la carne del huésped" [de manera que lo que] "distingue la deconstrucción como práctica textual es una doble lectura" (23), que se da en un nivel como comentario y en el otro "abriendo el texto a la ciega aleatoriedad o las elipsis dentro de la interpretación dominante" (23). En otras palabras, Derrida sugiere que la lectura deconstructiva de un texto conduce a una apertura que va desde el comentario a otra posición de donde mana un sentido que va más allá del logo-centrismo, un sentido que dice lo que no dice. Aquí se hace necesario aclarar -con Critchley- que el sentido de comentario para Derrida no significa la repetición del texto, sino una cuasi doble interpretación textual, o una interpretación de la interpretación. No obstante el teórico puntualiza que, aunque el comentario solo no abre todas las posibilidades del texto, sigue siendo válido, pues para establecer una lectura genuina hay que conocer toda la obra de un autor y los múltiples contextos; díganse políticos, literarios, filosóficos o históricos, que la informan. "El objetivo de la deconstrucción es, por lo tanto, localizar un punto de 
otredad dentro de la conceptualidad filosófica o logo-céntrica y entonces deconstruir esta conceptualidad desde esa posición de alteridad" (26). Este es el significado de la lectura doble. El primer instante corresponde a la lectura rigurosa, académica, al sentido intencional en la apariencia de comentario y el segundo aparece cuando se desestabiliza esta interpretación dominante. "Es el momento de atravesar el texto que posibilita la lectura para obtener una posición de alteridad o exterioridad, desde donde el texto puede ser reconstruido" (26-27). A partir de ese momento las dos lecturas se polarizan y dejan ver el sentido previsto. Es el "entrelazamiento de estos dos momentos, o trayectos de lectura -repetición y alteridad- lo que mejor explica el gesto doble de la lectura deconstructiva: la figura del quiasmo" (28).

¿No será acaso ese lugar, ese cruce donde emerge la figura ética el espacio de la poesía? Este laberinto gnoseológico persigue empujarnos a un límite en que se comienza a disolver el horizonte de la filosofía. "La deconstrucción es la escritura de un margen que no puede ser representado por la filosofía" (29), pero como todo intento de transgredir los límites, lo arduo está en crear las herramientas que nos permiten atravesar el velo conocido. En este caso "la única lengua disponible para la deconstrucción es la de la filosofía o el logo-centrismo. Por lo tanto, situarse fuera de él, si tal fuera posible, sería arriesgarse a carecer de los mismos recursos lingüísticos con los cuales deconstruir el logo-centrismo" (29). De manera que esta doble lectura -concluye Critchley- hay que entenderla como una que "incluye el análisis de la clausura y la interrogante de la ética" (30), una que a la vez que se expresa en el logo-centrismo, interrumpe su unidad al dar entrada a la alteridad. O como lo entiende Levinas en el sentido de una "crítica del sentido ontológico de la historia, que es siempre la historia de los vencedores, nunca de 
las víctimas y por lo tanto una historia de barbarie, contra la cual habla en términos similares a los de Walter Benjamín" (30). Así, la lectura derridiana "permite que el cuestionamiento ético surja de la deconstrucción [...] es historia leída desde el punto de vista de las víctimas de esa historia. Es, en un sentido complejo, historia ética. ¿No es acaso esa lectura la que hace Martí de las civilizaciones aborígenes de América, que lo lleva a reconstruir su historia para reinsertarla en las páginas que el colonialismo arrancó del libro de la historia y, por tal, convierte esta historia en ética? ¿No es acaso el heroísmo de re-escribir la historia desde la ética y reinstaurando la alteridad desde la muerte misma, desde las ruinas sepultadas, reabriendo los libros cerrados por el logocentrismo donde se asienta mi tesis de la escritura martiana como un paradigma que cruza el límite de la ontología y la episteme occidental para dar testimonio del "orbe ético"? $¿$ No vuelve a encenderse aquí, acaso, la sentencia "el universo habla mejor que el hombre?". Cerremos este fragmento con el resumen de Crichtley sobre la deconstrucción de Derrida para así fijar las audacias epistémicas en que él y Martí se cruzan. Una "lectura-clausura" -para acercarnos lo más posible al término derrideano- de un texto consistiría primero: "de un paciente y académico comentario, y segundo, en localizar una interrupción o alteridad dentro de esa dominante interpretación donde la lectura descubre perspicacias dentro de un texto para el cual ese texto es ciego" (30). Para Derrida esas "alteridades son momentos de trascendencia ética, en las cuales una necesidad otra que no es la ontología, se anuncia dentro de la lectura, un acontecimiento en el que el discurso ético de un texto anula lo.dicho antológicamente. (30).

Derrida proporciona ciertas herramientas destinadas a hacer posible que su lectura-clausura pueda constituirse en una práctica textual. Para ello brinda un concepto 
de escritura que se desplaza del concepto tradicional en el sentido de que no debe verse sólo como un modo de comunicación o de transmisión de significados ya que la escritura posee cualidades intrínsecas que deben ser consideradas. La primera es que es un medio de comunicación en el que el destinatario está ausente, -que es en primera instancia lo que la induce a crearse, y por eso es reiterativa lo que "asegura que un texto pueda seguir siendo leído después de la muerte de su autor" (34), -que es la razón que hace a Sócrates condenar la escritura en el $\mathrm{Fedro}{ }^{37}$. La segunda es "que rompe también con el concepto limitado de contexto porque el signo escrito excede siempre su contexto" (34) en la medida en que las palabras de un autor serán incluidas en otros textos después que éste no esté presente físicamente, incluso otorgándoles un sentido diferente para el que fueron inicialmente pensadas, descubriendo esa alteridad ética que subyace en los espacios liminales de ese texto, aprehendiendo su segunda naturaleza que se oculta de la primera lectura. De este modo podemos apreciar que la filosofía ética de Levinas está presente en el pensamiento filosófico de Derrida y atraviesa toda su entidad deconstructiva. Ésta viene a constituirse en una especie de hermenéutica que permite a la metafísica de Levinase igualmente a la de Martí, realizar la apertura de su lenguaje al máximo de sus posibilidades, reconquistando su esencia poética primera, como hace con el concepto de ética, es decir, poder ver del otro lado de las cosas, hacer de cierta forma coincidir la inmanencia con la trascendencia. En esa bisagra, para usar un término derrideano, se sitúa la escritura ética ética martiana. Con el método del comentario deconstructivo, atravesando el texto de norte a sur varias veces, con un paciente laboreo arqueológico, quizás se pueda paliar, aunque sea en una medida menos luminosa, ese apagamiento de la luz, ese sofocamiento del fuego primero que Martí veía en sus versos de Ismaelillo 
después que las visiones habían quedado atrapadas en la tinta, en la planicie de la letra impresa.

\section{El humanismo ético de Martí}

Tanto Martí, como posteriormente Levinas, descolonizan la ética, la vuelven a su esencia primera, original, a su origen natural. Es un salto hacia el porvenir del pasado que viene a insertarse en lo más radical del pensamiento contemporáneo. Si hace más de un siglo, la filosofía vuelve su interés de nuevo al sujeto, y casi todos los grandes filósofos desde Kant y Schopenhauer lo sitúan en el centro de su pensar, esto significa que, o es el asunto más importante de la filosofía que había sido absorbido por la teología, o urge descubrirlo en su justa medida, porque es lo más importante en el hombre, es su subjetividad, su modo de ser y de estar en el mundo. Ahora bien, la frase del "modo del ser" y la de "estar en el mundo" que he utilizo varias veces en este capítulo no son frases hechas. El modo en que el ser está en el mundo determina su actuar y de su actuar depende todo lo demás. Si ese es el asunto más importante de la filosofía, entonces lo que Martí hace y después harán Nietzsche, Heidegger, Sastre, Lacan, Foucault, Levinas, Derrida y otros, es sacar a la ética del conjunto de problemas de los que se ha ocupado la filosofía y ponerla en el centro del pensar de la episteme occidental, como una vez estuvo en Grecia. Al hacerlo, tanto Martí, como Levinas y los demás que han seguido esta huella, le devuelven la importancia y trascendencia que la ética tiene para la existencia, y afirman que la moral del bien y el mal, del cielo y el infierno y del premio y el castigo ha sido la fabricación de un discurso falso y de un sistema "arenoso" y hueco. De manera 
que esta afirmación martiana de que la ética es ley natural constituye quizás la primera instancia del paradigma de su escritura ética. De modo que con ellos se concluye que la ética, ni depende de ninguna divinidad que no sea la del propio ser y que además está inscrita en sus constitutivos esenciales en los arquetipos del inconsciente. Es decir, el deber y la bondad, que incluye la responsabilidad y el bienestar del otro, el deber entendido como la acción que el otro demanda para satisfacer sus necesidades, curar sus llagas, saciar su sed, levantar su estima e instaurar su dignidad como ley primera, ese es el verdadero sentido ético de la vida. Martí cree que ésta es parte del canto del hombre. ¿Estaría pensando tal vez en el momento en que los hombres cantaban a coro en el acto de la siembra los cantos que eran a la vez plegarias, versos, ruegos, protección del nosotros, expresión de la solidaridad, la filialidad y la fraternidad, todas sustancias de la ética como la entiende Levinas? Para que no quepa duda sobre el entendimiento que tiene Martí de la ética va el siguiente pensamiento: “... ningún dogma mental, impuesto por la educación a la mente, obra con tanta eficacia y certidumbre como éste que viene al hombre de sí mismo. La moral no perece porque cada hombre que nace, la fecunda [...] (Es ley natural). Es elemento natural (XXI, 169).

Es decir, es ley, elemento y fuerza naturales, no es parte de ningún dogma, nace con el hombre. Esto sólo puede haberlo alcanzado a través de la intuición poética, pues no había ningún pensamiento en su época donde pudiera encontrar tales referencias. Martí llega a afirmar en este texto que la filosofía primera es el hombre, único y verdadera fuente de saber porque -y aquí viene otra afirmación asombrosa- cómo puede el hombre deducir las leyes de las cosas si no se conoce bien él mismo? Mas, parece que sólo los seres abrazados en el sufrimiento, en circunstancias límites o aquéllos que se han 
podido liberar y reconquistar para el amor, la virtud, la libertad y la verdad ética han podido aprehender ese espacio en que el hombre, cincelado por sí propio y viviendo acorde a una estética de la existencia, es decir, una vida de constante crecimiento y perfeccionamiento del "ser en y para la humanidad" puede percibir la naturalidad de la conducta ética. Por tanto, esa percepción viene a ser una condición del existir de lo cual el hombre no puede escapar sin sentir que renuncia a su condición intrínseca, primera, esencial, que es su condición humana. Como quiera que lo miremos -pero mucho más comprensivo a la luz de las teorías de los filósofos aquí citados- la idea martiana de que la ética es ley natural es uno de sus grandes hallazgos y donde hay que buscar el origen del paradigma que es su escritura y también su ser.

Todo esto quizás explica por qué su vida y su creación estuvieron signadas por esa inagotable ansia de amar al hombre, aun a sabiendas de que era portador de cualidades que disminuían su ser. Sólo un recorrido por su poesía puede mostrarnos un sinnúmero de frases donde habla de las fealdades, las bajas pasiones, las ambiciones, los extravíos y el desenfrenado amor por lo material de los hombres. No sólo lo contempla, sino que es víctima de éstos. Pero si bien no diferencia a la hora de amar al hombre por su raza o color, o condición social, a la hora de entregarle su amor,si lo diferencia por su conducta. Por ejemplo en "Banquete de tiranos" de Versos libres dice: "hay una raza vil de hombres tenaces / De sí propios inflados, y hechos todos, / Todos, del pelo al pie, de garra y diente: / Y hay otros, como flor, que al viento exhalan / En el amor del hombre su perfume" (107). Sin embargo a los viles no los rechaza en su condición de hombres, sino que les lanza en cara su verdad y critica su conducta desdeñable, pero como tiene "fe en el mejoramiento humano y en la utilidad de la virtud" $(17)^{38}$, él quiere abrazar a estos 
hombres, sacarlos de la ciudad que los envilece "Y donde el aire es puro, y el sol claro / Y el corazón no es vil, volar con ellos" (224). ${ }^{39}$

El humanismo ético martiano es un intento de recuperar la jerarquía que el intelectual ocupaba antes de la modernidad, el prestigio que conservó hasta el Renácimiento y que fue desplazado por el utilitarismo y el progresismo de la sociedad industrial. Este humanismo, sin embargo se diferencia del humanismo burgués clasista y reaccionario, de la misma manera que la ética de Levinas se diferencia de la ontología del discurso racional. Con la Ilustración y después de la Revolución Industrial y la escisión que se produce entre la vida del espíritu y la materia, el estado moderno da auspicio a un nuevo tipo de intelectual que ya no es el clásico humanista, sino el científico, el astrónomo, el físico, el matemático. Hacia la segunda mitad del siglo XIX, época en la que vive Martí, la crisis del humanismo es evidente y lo que surge para dominar el pensamiento moderno son corrientes filosóficas ligadas al cientificismo y al progresismo de turno tales como el positivismo, el pragmatismo, el evolucionismo, etc., en que el humanista no tenía ningún decir. Ahora se invierte la fórmula. Si en la edad media tardía y principios del Renacimiento, la palabra peligrosa, el logos que había que conjurar, era el del astrónomo, pues ponía en peligro la estabilidad de la inmovilidad, del todo debe quedarse donde está, incluidas las estrellas, en la época moderna pasa a ser el humanista quien se coloca en la línea de fuego del poder pues sus análisis decconstructivos de la entidad hegemónica -que ya no puede ejercerse sobre la ignorancia de la plebe,- ponen en peligro su estabilidad y control sobre las masas.

En la modernidad todo saber real y todo hombre que lo ejerza estará, por definición, fuera de los márgenes de ésta. La modernidad, en realidad, da muerte al saber 
y lo sustituye por el conocimiento. Ya no será la aventura del saber filosófico, sino del conocimiento científico. La llustración, ciertamente elimina el despotismo ilustrado, el gobierno del soberano, del emperador, pero inaugura el gobierno del dictador y del tirano en el seno de la institución del nuevo gobierno: el estado moderno. En la Introducción a la Dialéctica de la Ilustración, ${ }^{40}$ uno de los libros más profundamente críticos de todo el proceso de modernización que comienza con la Ilustración en el siglo XVIII se lee: "La Ilustración disuelve los mitos y entroniza el saber de la ciencia, que no aspira ya [...] a la verdad, sino a la explotación y al dominio sobre la naturaleza desencantada. En el proceso de la Ilustración el conocimiento se torna en poder y la naturaleza queda reducida a "pura materia o substrato de dominio" (12). Según Horkheimer lo diferente o desconocido resultan realidades desconocidas para ella. Esto "marca el curso de la desmitologización de la Ilustración que termina reduciendo todo a la 'pura inmanencia'. La Ilustración se relaciona con las cosas 'como el dictador con los hombres': las conoce en la medida que puede manipularlas, someterlas". (12)

En estas condiciones el humanista pasa a ser un ermitaño o es absorbido por las instituciones que controlan el conocimiento en la modernidad, que ya no es la iglesia, sino los organismos o entidades que ejercen el control hegemónico del estado. Entre la trascendencia del mito y la inmanencia de la modernidad ilustrada hay otra edad oscura, otra edad media, la de la sociedad industrializada y tecnológica que Martí critica con todas las fuerzas de su intelecto y toda la pasión de su poética. Su labor contra-discursiva nace de su comprensión de que el saber transformado en conocimiento es la nueva herramienta del poder. Su renuncia de la institución literaria es igualmente resultado de esta comprensión. Su observación del hecho de que los escritores modernos -con sus 
honrosas excepciones- están entretenidos en pulir la forma, o en recrear mundos exóticos, lejanos, ajenos, o en busca del aplauso y la fama que les provea riqueza y confort, no le parece digno, ni justo. Por eso asume la posición del humanista ético porque entiende que en épocas de crisis social el papel del escritor está en asumir una postura crítica radical y usar su instrumento artístico para desenmascarar las fabricaciones del poder. En su criterio "la palabra es una conquista abominable" cuando quienes la usan no las ponen al servicio del honor y del amor. De ahí que según Martínez Estrada, prefiera "sus trabajos como empleado, funcionario y corresponsal preferidos a cualquier canonjía sinecura, profesional o no..."41

Si el poeta, el humanista, el intelectual no asumen su posición de pupila órfica como dice cuando habla de Emerson- para vigilar desde la periferia las falacias del discurso político y frenar a la maquinaria del poder ¿quién desenmascara y denuncia sus prácticas violentas? ¿Quién puede detener la ceguera de esa entidad mesiánica que en su embriaguez tecnológica pone la casa común al borde de un colapso ecológico y lleva al hombre a cometer repudiables genocidios? "La Ilustración se inició bajo el signo del dominio y la reductio ad hominem"42 y este proceso termina "no sólo por eliminar el mito, sino todo 'sentido' que trascienda los hechos brutos: 'En el camino de la ciencia moderna [...] los hombres renuncian al sentido" (13). En esa pérdida del sentido que ha producido los interminables conflictos bélicos de la modernidad y la dilapidación de incontables recursos materiales y humanos se manifiesta la ausencia del humanista comprometido con la verdad. Su humanismo no es de índole nacionalista en el sentido en que la modernidad lo entiende, ni parte de los discursos dominantes de esta época porque va más allá de la política, de la ciencia, de la religión y del progreso. Ninguno de esos 
discursos a los que veía fragmentados e incompletos podía dar respuesta a las necesidades de la humanidad en sus aspiraciones de construir un mundo mejor. El sentido de patria martiano que desborda el de los nacionalismos modernos es el de "patria es humanidad de los estoicos", entendido como la responsabilidad que cada hombre tiene de defender la casa común y a cada otro hombre en cualquier rincón de la tierra. La patria del hombre es para Martí la humanidad. Denunciar entonces el exceso de poder de las naciones industrializadas y a sus colonialismos e imperialismos con el ansia de detener a los "gigantes con botas de siete leguas" se convirtió en su modo de estar en el mundo y en el ser, un mundo que para él seguía estando encantado, un ser que para él era su hermano dondequiera que hubiera nacido.

Por eso podemos encontrar en su escritura una denuncia de los colonialismos en los pueblos árabes, en los pueblos asiáticos, en los pueblos latinoamericanos y hasta en los propios fragmentos de pueblos insertados en las metrópolis, como son los casos de los pueblos indios y negros norteamericanos a quienes igualmente defendió con amor hacia ellos e indignación hacia sus opresores. Esta crítica implacable que despliega contra los colonialismos y los imperialismos del estado moderno es una de las más elevadas expresiones de su humanismo ético, que no es otra cosa que el modo en que Martí actúa como testigo de su tiempo y de su porvenir. La reacción de la intelectualidad europea después del desastre de la Primera Guerra Mundial fue a la vez de repudio y de nausea; repudio al horror que podía producir la razón y nausea de la barbarie, de la violencia irracional del poder de la lógica racional. Nietzsche lo había descrito muy bien en su Zaratustra ${ }^{43}$ cuando decía: "Llámase Estado el más frío de todos los monstruos fríos. Y miente fríamente, siendo su mentira ésta: 'Yo, el Estado, soy el pueblo" (54). En esta idea 
hay otra coincidencia con Martí quien dice que conoce el monstruo porque ha vivido en sus entrañas. En nombre del pueblo el estado "ha ideado una treta diabólica, un Caballo de Troya de la muerte, magníficamente enjaezado con honores de púrpura" (55) un lugar "donde el suicidio de todos se llama vida" (55). Critica también el tópico del "dinerismo": "Loada sea la humilde pobreza" (56) muy cercana a la frase de Lezama en su ensayo "Secularidad de Marti": "Tomará nueva carne cuando llegue el día de la desesperación y la justa pobreza" ${ }^{\text {44 }}$. Las coincidencias y la crítica a ese poder hegemónico de la modernidad burguesa que aparece en la obra de tantos filósofos y escritores desde Martí hasta el presente no es otra cosa que la necesidad que la verdad tiene de abrirse paso y del ser ético del hombre queriendo expresarse. En tal sentido, a propósito de la entidad intelectual Edward Said deja el testimonio de sus preocupaciones y reflexiones en Representations of the Intellectuals. ¿Qué significa ser hoy un intelectual? Said parte de la premisa de que el intelectual es un exiliado que debe confrontar el poder con la verdad, coincide con la pupila que vigila el curso de la sociedad desde la periferia de que hablamos antes referido a Emerson. Una vez que el intelectual entra en la zona de confort, del compromiso con las instituciones dimanantes del poder, su voz y su verdad están comprometidas.

De cierta forma Said nos pinta el cuadro de lo que sucede cuando los intelectuales sucumben ante la seducción del dinero, del poder o de la especialización. Said, quien cita a Martí en su libro Culture and Imperialism como uno de esos escritores que se oponen en el XIX al colonialismo desde la honestidad y la integridad, también confirmó con su vida esos valores y se opuso al dogma y a la rigidez que adquiere cualquier entidad que ejerce el control absoluto de todo lo que es y existe, que conduce, a la postre a una lenta 
pero segura autodestrucción. Martí es ejemplo de independencia intelectual y libertad creadora, aunque ello fue a costa de ganar el pan en empleos que no constituían para él estímulos, ni económica ni intelectualmente, pero que no comprometían su integridad seguro de que "toda complacencia destruye la lealtad del movimiento ético",45. Al margen de las instituciones concibió su escritura porque sabía que ese era el único modo de ejercer su humanismo ético, de crear su contra-discurso moderno y dejar su aporte para construir un mundo más humano, dejar su huella palpitante, en el sentido en que la entiende Levinas como "irreversibilidad", como "ab-solución", como "omnipotencia frente a toda negatividad" 46 "con todos y para el bien de todos" en el "culto a la dignidad plena del hombre" como ley primera, no en otro mundo, sino en el que nos ha sido otorgado.

Said se pregunta qué exactamente representa el intelectual hoy. La mejor respuesta la encuentra en el sociólogo norteamericano C. Wright Mills, quien afirmaba en 1944 que los intelectuales libres tenían dos posibilidades que enfrentar: "o al sentido de desaliento resultado de la impotencia y la marginalidad o con la opción de unirse a las instituciones superiores, las corporaciones o gobiernos como miembros de un grupo [...] pequeño que toma decisiones irresponsablemente" (20). De manera que la divisa del intelectual que es la comunicación "está siendo entonces, expropiada, dejando a los pensadores con una tarea suprema" (21). Said cita entonces al propio Mills cuando dice: "El artista o el intelectual independiente están entre las pocas personalidades que existen equipadas para resistir y luchar los estereotipos y la consecuente desaparición de las cosas auténticas de la vida" (21). Después continúa diciendo que el "los mundos arte de masas y de manipulación masiva están cada vez más orientados a las demandas de la 
política. Es por eso que es en la política en la que la solidaridad intelectual y el esfuerzo deben centrarse" (21). Luego concluye asegurando que "si el pensador no se relaciona con el valor de la verdad en la lucha política, no puede, responsablemente (honestamente) enfrentar la experiencia de la vida en su totalidad" (21). Ese intelectual comprometido con la verdad, al margen del soborno de las instituciones, en batalla constante contra el poder hegemónico cualquiera que sea su disfraz, con las herramientas poderosas de su pensamiento y con la energía revolucionaria de su acción, con las armas del juicio, ese que demanda Mills y demanda Said encarna en Martí. Por eso he dicho que él es un arquetipo de hombre y que su humanismo ético es el paradigma en la acción, del ser para la ética, como su escritura ética es su paradigma para el arte, la poesía, el pensamiento, el saber. Las ideas expuestas por Said a propósito de Mills son de la misma índole crítica que las que plantean Adorno y Horkheimer en su Dialéctica de la Ilustración, como lo son las del propio Martí en su análisis de la sociedad norteamericana vertida en sus crónicas, discursos, ensayos, artículos y cartas a lo largo de los 15 años en que residió en los Estados Unidos. En "Prontuario de temas martianos que reclaman dilucidación" Manuel Pedro González, uno de sus grandes estudiosos, consigna esta frase: "El contenido ético de su obra es ecuménico y podemos augurar que no envejecerá, cualquiera sea el rumbo que la humanidad pudiera seguir [...] La moral de Martí es de aplicación y sentido universales porque está indemne de dogmatismos limitadores y de prejuicios religiosos, raciales o clasistas" (103-04). ${ }^{47}$

El legado fundamental que se desprende de la escritura martiana es que la ética es el lenguaje privilegiado de la humanidad, de la fundación de la verdad del ser humano y del mundo que habita y por eso es ecuménico, más allá de cualquier ideología, de 
cualquier ontología, de cualquier epistemología, es el lenguaje de lo que está por venir. La metafisica ética propuesta por Levinas, basada en una subjetividad altérica, hospitalaria y sagrada lo mismo que el humanismo ético elaborado por Martí en su escritura son hoy más necesarios que nunca ante los estragos que el humanismo universalista occidental, centrado en un sujeto racional, egotista ha causado en la vida de las sociedades colonizadas. La metafísica ética de Levinas y el humanismo ético de Martí proponen una responsabilidad ante la humanidad del otro, una "responsabilidad que vacía al Yo de su imperialismo y de su egoísmo -aunque se trate de egoísmo por la salvación-. [...] El yo ante Otro es infinitamente responsable. El Otro que provoca ese movimiento ético en la conciencia...". 48 La propuesta central de ambos pensadores es la constitución de una subjetividad que anule el sujeto centrado en el yo y erija, en cambio, el humanismo del otro hombre como epifanía. La crisis de los ideales del humanismo burgués basado en el universalismo y el carácter excepcional de la civilización occidental ha puesto de manifiesto desde el mismo principio la ineficacia e inoperatividad de tal ideología. El exceso de poder, la abundancia (llevada al delirio del derroche), el hombre vaciado de su divinidad, de su dignidad y de su libertad, asaltado constantemente en su conciencia por las más pueriles ambiciones, son algunas muestras incontestables de estas falaces ideas impuestas como verdades por la fuerza excesiva de la institución política y de la técnica modernas. Que el hombre se haya convertido en juguete de sus propias creaciones, muchas de las cuales tienen el poder de aniquilar varias veces todo lo que existe, incluyéndolo a él mismo es la señal más clara de "la inestabilidad y el carácter falaz de la conciencia de sí en el cogito, que debería sin embargo detener los engaños del genio maligno y restituir el universo..." ${ }^{49}$ Uno de los imperativos del nuevo siglo será 
sustituir esa subjetividad racional por una nueva subjetividad basada en la ética. Sólo así será posible retomar el camino del saber que ponía en el principio de su cosmovisión el conocer el ser alcanzado por el paganismo, el misticismo, el budismo y otras corrientes de pensamiento antiguo que descubrieron que la energía que impulsa al ser a trascender sus limitaciones se expresa en la belleza, el amor, la bondad, la libertad y el Dios que habita en el cielo de su mundo interior. Allí en ese abismo se suspenden, como puentes hacia el más allá del ser dentro del ser, las metáforas, "esa maravilla del lenguaje cuyo análisis filosófico denunciará, sin tregua, 'el origen verbal', sin destruir la intención evidente que la penetra". Cualquiera que sea su historia psicológica, social o filológica, el más allá que produce la metáfora tiene un sentido que trasciende esta historia". ${ }^{50}$

Esta subjetividad deberá situarse por encima y por debajo de toda reflexión, "sorprender en suma, en el fondo del Yo, una sinceridad sin equívoco y una humildad de servidor que ningún método trascendental podrá corromper". ${ }^{51}$ De esa humildad es de la que hablan -como hemos citado- Martí, Nietzsche, Lezama y Levinas, dos filósofos y dos poetas, las dos caras del pensar que una vez fueron la expresión de la unidad en las mitologías. Todo lo anterior explica la real sincronía entre el pensamiento martiano expresado en su humanismo ético y la metafísica de Levinas como primera filosofía. Ambos fueron a buscar la sustancia y el contenido de su cosmovisión en el pasado, no en el futuro escatológico y mesiánico del progreso. Walter Benjamín sostiene en su una de sus tesis históricas (IX) -que igualmente está Nietzsche-que no existe ningún progreso, ni un gran relato y que la historia no pude ser resumida racionalmente; más bien lo que hay son representaciones del pasado que las clases dominantes han fabricado, dejando en el silencio las voces de los vencidos. En la citada tesis describe lo siguiente: "Hay un 
cuadro de Klee que se titula Angelus Novus. Se ve en él un ángel, al parecer en el momento de alejarse de algo sobre lo cual clava la mirada. Tiene los ojos desorbitados, la boca abierta y las alas tendidas. El ángel de la historia debe tener ese aspecto" (26). ${ }^{52}$ Luego plantea que en vez de una sucesión lineal de hechos, el va desechos y ruinas. Quisiera detenerse a descomponer lo destruido, mas "un huracán sopla desde el paraíso y se arremolina en sus alas, y [...] lo arrastra irremisiblemente hacia el futuro, al cual vuelve las espaldas, mientras el cúmulo de ruinas crece ante él hasta el cielo. Este huracán es lo que nosotros llamamos progreso" (26).

La Crítica de Benjamín arremete contra el progreso como telos puesto que esta energía como crecimiento y avance es exterior al hombre, desconociendo su humanidad y por tanto se convierte en una ideología que se fanatiza y deja una historia de crueldad, opresión y destrucción de vidas y del tejido milenario de los intercambios multiculturales de las sociedades tradicionales. En tal sentido Benjamín plantea la necesidad de volver al pasado y demostrar que no hay una historia, sino muchas historias y que todas tienen el mismo derecho a ser contadas. Ese es el mismo sentido en que Martí cuestionaba la excepcionalidad de la cultura occidental del siglo XIX. En las tesis de Benjamín aparece la misma idea martiana que explicamos en "Arqueología de la tradición" de que no hay un solo modelo de humanidad como pretendía hacer ver la civilización occidental, sino que es uno más entre otros muchos. Por eso resulta vital la crítica que reclamaba Martí, y también Nietzsche, Adorno, Horkheimer, Benjamín, Levinas y Derrida y tantos otros porque ayuda a develar al hombre que toda manifestación de universalismo, llámese Ilustración, civilización o globalización, es una manera de ejercer el imperialismo y de crear una narrativa única, una ideología dominante, una exacerbación de la ignominia del 
poder en el cuerpo y la conciencia de otros pueblos distintos, diversos, heterogéneos. Esa diversidad es precisamente una de las maravillas de lo que llamamos "mundo", pero que sólo puede ser entendido por una subjetividad altérica fundada en las cenizas del sujeto cartesiano. Benjamín entiende que el pasado no es el cementerio que la modernidad ha querido construir con el privilegio de reconocer sólo algunos muertos "ilustres", sino que es algo que hay que reconstruir a modo de salvar la mayor cantidad de imágenes posibles del olvido porque, como se sabe, quien olvida el pasado está condenado a repetir los mismos errores at vitam aeternam. De ahí que afirme en su tesis VI: "Articular históricamente el pasado no significa conocerlo 'tal como verdaderamente fue'. Significa apoderarse de un recuerdo tal como éste relumbra en un instante de peligro",53. Más adelante argumenta: "En cada época es preciso arrancar la tradición de manos del conformismo, que está siempre a punto de someterla" ${ }^{\$ 4}$. Benjamín concluye esta tesis con la idea siguiente: "Encender en el pasado la chispa de la esperanza es un don que sólo se encuentra en aquel historiador consciente de esto: tampoco los muertos estarán a salvo del enemigo si éste vence. Y este enemigo no ha cesado de vencer" ${ }^{55}$

Estos criterios confirman de un modo alentador cuanta certeza había en el pensar de Martí al decidir emprender su viaje en el sentido contrario al de su época, hacia el pasado de la tradición. Los hombres de hoy tenemos la fortuna de haber recibido en herencia un pensamiento que en el siglo XIX supo revelarse contra todos los metarrelatos y, dinamitando la lógica que predominaba entre sus contemporáneos, erigir un pensar arqueológico en el que revivía un humanismo que se alimentaba de ese pasado que era algo remoto ya para la modernidad. A propósito del pasado Walter Benjamín revela dos cosas muy interesantes. La primera, que el historiador debe ser un "cronista" -forma 
elegida por Martí para describir el mundo de su época- que no descarte acontecimiento alguno porque sea grande o pequeño, porque la historia es un relato y cada fragmento es importante. La segunda, que "sólo a la humanidad redimida le concierne enteramente su pasado. Lo que quiere decir: sólo para una humanidad redimida se le ha vuelto citable su pasado en cada uno de sus momentos". ${ }^{56}$ El humanismo ético martiano, que se erige en su momento como una crítica severa a la sociedad elitista y reaccionaria de su época, era un reclamo, un grito de protesta a favor de una humanidad redimida. Ese grito, esa protesta y esa crítica tienen hoy mayor repercusión y resonancia que nunca puesto que vamos acercándonos cada vez más al umbral de ese nuevo mundo con nuevos altares que él soñó, un mundo de una poesía colosal, más allá de las ideologías, de las teologías mesiánicas y dogmáticas, del racionalismo teleológico universalista, un mundo, en fin, fundado en la humanidad del otro hombre como la radiante epifanía de lo infinito sagrado. 
${ }^{1}$ Cintio Vitier. Temas martianos. (La Habana: Letras Cubanas, 2004).

${ }^{2}$ José Martí. Obras completas. (La Habana: Editorial Ciencias Sociales, 1975), 359-370. "Juicios" aparece como parte del tomo XIX: Viajes, Diarios, crónicas, Juicios.

${ }^{3}$ Flores D'Arcais, Paolo. Hannah Arendt. Existencia y libertad. (Madrid: Editorial Tecnos, 1995), 57-58

${ }^{4}$ Aparece publicado en La Opinión Nacional. Caracas, 19 de mayo de 1882, año que señalamos como el arranque del gran salto de su escritura ética. Según Obras Completas, t. XIII, pp. 17-30. Está considerada una de las piezas claves de su ensayística y en ésta dice cosas sobre Emerson que podrían decirse de él mismo. Sus ideas sobre el arte, la religión, la ciencia y la naturaleza y la vida son particularmente importantes.

5 José Martí. Poesía completa. Ed. Carlos Javier Morales. (Madrid: Alianza Editorial, 1995), 208. Este verso aparece en "Contra el verso retórico", poema que abre su poemario Flores del destierro.

${ }^{6}$ Michel Foucault. Ethics, Subjectivity and Truth. Ed. by Paul Rabinow. (New York: The New York Press, 1997).

${ }^{7}$ Hubert L. Dreyfus y Paul Rabinow. Michel Foucault: más allá del estructuralismo y la hermenéutica. (Buenos Aires: Ediciones Nueva visión, 2001).

${ }^{8}$ En la teoría semanalítica de Julia Kristeva, ésta plantea que el sujeto construye su subjetividad en la jora semiótica, del griego espacio, lugar; y a esta teoría llama semanálisis. Éste, al que también denomina "ciencia de la significancia" cuestiona la materialidad misma del lenguaje hasta diluirla, "hasta hacerla retroceder a su origen: lugar a la vez previo y exterior al sujeto, pura pulsión, reino de lo semiótico por excelencia, "musical", pre-verbal, anterior a todo signo, a cualquier posición del sujeto en el lenguaje y, por tanto, anterior al ego, al orden simbólico". La jora, donde se excluye la representación del significado, detecta los ritmos, los silencios, las aliteraciones, y los gestos. Es anterior a la división de los sexos e incluye lo femenino y lo masculino. Ese espacio de construcción de la subjetividad violenta la representación socio-cultural del lenguaje y entra en contacto -desprendido de lo temporal y espacial- con los límites más absolutos: la belleza y la muerte.

${ }^{9}$ Cintio Vitier, 83 .

${ }^{10}$ Vitier, 84.

${ }^{11}$ Vitier, 84.

${ }^{12}$ Emmanuel Levinas, el filósofo lituano-francés es valorado por la filosofía contemporánea como el pensador más original y revolucionario en el ámbito de la ética. Jacques Derrida lo consideraba el pensador más importante del siglo XX pues ha dado un vuelco a la filosofia que aún no se puede aquilatar en toda su dimensión.

${ }^{13}$ Simon Critchley. The Ethics of Deconstruction: Derrida and Levinas. (Oxford: Blackwell, 1992), 3.

14 Adrian Theodor Peperzak. Beyon the Philosophy of Emmanuel Levinas. (Illinois: Northwestern University Press, 1997), 4.

${ }^{15}$ Peperzak, 4. 
${ }^{16}$ Peperzak, 4.

17 Jacques Derrida. Adieu to Emmanuel Levinas. California: Stanford University Press, 1999. Este volumen contiene el discurso dado por Derrida en el funeral a Emmanuel Levinas el 27 de diciembre de 1995 y sus contribuciones al Coloquio organizado para celebrar el primer aniversario de la muerte de Levinas.

${ }^{18}$ Simon Critchley.

${ }^{19}$ Critchley, 16.

${ }^{20}$ Derrida, 136.

${ }^{21}$ Derrida, 10.

${ }^{22}$ Derrida, 11.

${ }^{23}$ The Ethics of Deconstruction: Derrida and Levinas. Es uno de los estudios más completos sobre la ética en estos dos pensadores y al cual haremos referencia a lo largo de todo el capítulo. Critchley sobre todo insiste en el concepto de deconstrucción de Derrida como un ejercicio ético. En él entran los conceptos de la hermenéutica de la lectura y la escritura como actos éticos, pero apunta más allá de estos al concebir la crítica que alcanza todos los niveles del texto en el acto reconstructivo como una conducta ética. Todas las traducciones son mías.

${ }^{24}$ En este libro Derrida extiende su análisis de Levinas en direcciones no exploradas anteriormente y hace una lectura radical de su obra maestra Totalidad en infinito considerándolo un inmenso tratado sobre la hospitalidad. Como se puede leer en su contraportada Derrida plantea las cruciales interrogantes de nuestro tiempo "en los términos más explícitos, moviéndose hacia delante y hacia atrás entre los argumentos filosóficos y la discusión política sobre las leyes migratorias, la paz, el estado de Israel, la xenofobia recordándonos con cada movimiento que el pensar no es una cuestión de neutralidad abstracta, sino un gesto de hospitalidad por lo que sucede y lo que pueda suceder".

${ }^{25}$ M. C. Beatriz Liliana De Ita Rubio. "Emmanuel Levinas: el deseo de trascendencia como esencia de la subjetividad". Revista de observaciones filosóficas no. 1 (2005): 1-13.

${ }^{26}$ Emmanuel Levinas. Totalidad e infinito. ( Salamanca: Editorial Sígueme, 1987).

${ }^{27}$ Emmanuel Levinas. Ética e infinito. (Madrid: La balsa de la medusa, 2000).

${ }^{28}$ José Martí. Poesía commpleta, 28

${ }^{29}$ Evelyn Picon Garfield e Ivan A. Schulmam. "Las entrañas del vacio: ensayos sobre la modernidad hispanoamericana. (México: Cuadernos Americanos, 1984), 93.

${ }^{30}$ Emmanuel Levinas. Ética e infinito, 88.

${ }^{31}$ Jose'Martí. Poesia completa. Ed. Carlos Javier Morales (Madrid: Aliznza Editorial, 1995), 212

${ }^{32}$ Levinas. 88.

${ }^{33}$ Manuel J. Caro and John W. Murphy. Ed. The World of Quantum Culture. ( Connecticut: Praeger, 2002). Aunque el término está tomado del mundo de la física, esta compilación de ensayos sobre la estética cuántica muestra como falsa la separación entre el mundo físico y el mundo inmaterial que ha caracterizado 
a la ciencia desde el Renacimiento. Para estos autores la intuición y la materia están integradas en un todo indiferenciado.

${ }^{34}$ Simon Critchley, 14.

${ }^{35}$ Critchley, 15.

36 Friedrich Nietzsche. Asi hablaba Zaratustra. (Bogota: Panamericana Editorial, 2000). "Cuando Zaratustra estaba de nuevo solo, dijo para sus adentros: ¿Será posible? ¡Este viejo santo en su bosque no se ha enterado aún de que Dios ha muerto!", 14.

${ }^{37}$ Jacques Derrida utiliza este fragmento igualmente en La diseminación para argumentar su apartado no. 8. "La herencia del fármacon: la escena de familia, 217-219.

${ }^{38}$ Del prólogo a Ismaelillo en Poesía completa ya referido.

${ }^{39}$ Carlos Javier Morales

${ }^{40}$ Max Horkheimer y Theodor Adorno. Dialéctica de la Ilustración: Fragmentos Filosóficos. (Valladolid, España: Editorial Trotta, 1994).

${ }^{41}$ Martí revolucionario, 550

42 Horkheimer y Adorno, 13.

${ }^{43}$ Nietzsch, Friedrich. Así hablaba Zaratustra. (Bogotá: Panamericana Editorial, 2000).

${ }^{44}$ Marti en Lezama, (La Habana: Centro de Estudios Martianos, 2000), 22.

${ }^{45}$ Emmanuel Levinas. El humanismo del otro hombre. (México: Siglo XXI Editores, 2006), 62.

${ }^{46}$ Levinas., 79.

${ }^{47}$ Manuel Pedro González. "Prontuario de temas martianos que reclaman dilucidación" en Anuario del Centro de Estudios Martianos, vol. 1 (1969): 103-115.

${ }^{48}$ Levinas, 62-63.

${ }^{49}$ Levinas, 85 .

${ }^{50}$ Levinas, 66.

${ }^{51}$ Levinas, 66.

${ }^{52}$ Walter Benjamin. Tesis sobre la historia y otros fragmentos. Ed. y trad. Bolívar Echeverría, 26.

${ }^{53}$ Walter Benjamin, 23.

${ }^{54}$ Benjaamin, 23. 
${ }^{55}$ Benjamin, 24.

${ }^{56}$ Benjamin, 22. 


\section{Bibliografia*}

Acosta, Leonardo. José Martí, la América precolombina y la conquista español. La Habana: Casa de las Américas, 1974.

Adorno, T. W. Mínima moralia: reflexiones sobre la vida dañada. Madrid: Taurus, 1998.

y Max Horkheimer. Dialéctica de la Ilustración: Fragmentos Filosóficos.

Valladolid: Editorial Trotta, 1994.

--------.. Consignas. Trad y única edición en castellano autorizada por Suhrkamp Verlag. Buenos Aires: Amorrortu Editores, 1969.

La ideología como lenguaje. Trad. Justo Pérez Corral. Madrid: Taurus, 1971.

Arguedas, José María en La mesa redonda sobre "Todas las sangres" de 23 de junio de 1965, Lima, Pontificia Universidad Católica del Perú: Instituto de Estudios Peruanos, (2000).

--------. Formación de una cultura nacional indoamericana. México: Siglo XXI Editores, 4 ta edición.

Atterton, P., Calarlo, M. and Maurice Friedman, eds. Levinas ans Buber: Dialogue and Difference. Pennsylvania: Duquesne University Press, 2004.

Augier, Ángel. Acción y poesía en José Martí. La Habana: Letras Cubanas, 1982.

Baker, Peter. Deconstruction and the Ethical Turn. Gainesville: University Press of Florida, 1995.

Ballón, José. Autonomía cultural americana: Emerson y Martí. Madrid: Editorial Pliegos, 1986.

Baquero, Gastón. La fuente inagotable, Valencia: Editorial Pretextos, 1995.

Barthes, Roland. El grado cero de la escritura, Buenos Aires: Siglo XXI Editores, 2003. S/Z. $1^{a}$ ed. Buenos Aires: Trad. Nicolás Rosa. Buenos Aires: Siglo XXI Editores 2004.

Crítica y verdad. Buenos Aires: Siglo XXI Editores, 1976.

\footnotetext{
* Esta es la bibliografía selecta de los textos que han sido citados directamente en la tesis. En algunos casos pertinentes se incluyen también otros trabajos que hayan resultado relevantes en la investigación.
} 
Mythologies. Trans. Annette Lavers. New York: Hill and Wang, 1972.

Beatty, Jack. The Age of Betrayal: The Triumph of Money in America, 1865-1900. Nueva York: Alfred A. Knopf, 2007.

Bellido Aguilar. Víctor R, Martí: La juntura maravillosa (de la modernidad a la posmodernidad). La Habana: Casa Editora Abril, 2000.

Benjamín, Walter. Sobre el concepto de historia. Ed. y Trad. Bolivar Echevarría. http://www.bolivare.unam.mx/traducciones/indice tesis.html.

Bérubé, Michael. Ed. The Aesthetics of Cultural Studies. Oxford: Blackwell, 2005.

Bowman, Paul, ed. Interrogating Cultural Studies, London: Pluto Press, 2003.

Calisnescu, Matei. Five Faces of Modernity: Modernism Avant-Garde Decadence Kitsch Postmodernism. Durham: Duke University Press, 1987.

Camayd-Freixas, Erik. Ralismo mágico y primitivismo. Maryland: University Press of America, 1998.

Caro J. Manuel y John W. Murphy, ed. The World of Quantum Culture. Connecticut: Praeger, 2002.

Centro de Investigaciones Literarias de la Casa de las Américas. Barcelona: Editorial Anagrma, 1971.

Colón, Cristóbal. Los cuatro viajes del almirante y su testamento. México: Espasa Calpe, 1994.

Conway, Christopher. "The limists of Analogy: José Marti and the Haymarket Martyrs", A Contracorriente, Vol. 2. no.1 (2004): 33-56.

Cortés, Hernán. Cartas de relación, México: Editorial Porrua, 1993.

Critchley, Simon. The Ethics of Diconstruction: Derrida and Levinas, Blackwell, Oxford: UK, 1992.

"Why I love Cultural Studies" in Interrogating Cultural Studies: Theory,

Politics and Practice. Londres: Pluto Press, (2003): 59-75.

Darío, Rubén. Antología poética. Madrid: Editorial Edad, 1998.

Deleuze, Pilles y Feliz Guatari. El Antiedipo: capitalismo y esquizofrenia. Trad. F. 
Monge. Barcelona: Barral, 1974.

Dleuze, Guilles. Nietzsche and Philosphy. Trans. Hugo Tomlinson. New York: Columbia University Press, 1983.

Derrida, Jacques. La diseminación. Madrid: Fundamentos, 1975.

Adieu To Emmanuel Levinas. Trans. by Pascale-Anne Brault and Micael Nass. California: Stanford University Press, 1999.

Dreyfus L. Hubert y Paul Rabinow. Michel Foucault: más allá del estructuralismo y la Hermenéutica. Buenos Aires: Ediciones Nueva Visión, 2001.

Díaz del Castillo, Bernal. Historia verdadera de la conquista de la nueva España. Madrid: Castalia Didáctica, 1999.

Eliade, Mircea. El mito del eterno retorno. Madrid: Emecé Editores, 1972.

-.-.-. Lo sagrado y lo profano. Madrid: Guadarrama, 1973.

Mito y realidad. Madrid: Guadarrama, 1978.

Tratado de historia de las religiones. México: Ediciones Era, 1975.

Estrade, Paul. "Marí: orden y revolución". Anuario del centro de estudios martianos, La Habana: Centro de Estudios Martianos, No. 2, (1979): 75-91.

Fernández Retamar, Roberto. Todo Calibán. La Habana: Letras Cubanas, 2000.

Para el perfil definitivo del hombre. La Habana: Letras Cubanas, 1995.

Para una teoria de la literatura hispanoamericana. México: Editorial Nuestro Tiempo, 1976.

Flores D'Arcais, Paolo. Hannah Arendt: existencia y libertad. Trad. César Cansino, Madrid: Editorial Tecnos, 1996.

Foucault, Michel. Las palabras y las cosas: una arqueología de las ciencias humanas. Trad. Elsa C. Frost. Buenos Aires: Siglo XXI Editores, 2002.

Ethics: Subjectivity and Truth. Ed. Paul Rabinow. New York: New Press, 1997.

El orden del discurso. Buenos Aires: Tusquests, 2004. 
Arqueología del saber. Trad. Aurelio Garzón del Camino. Buenos Aires:

Siglo XXI Editores Argentina, 2004.

Vigilar y castigar: nacimiento de la prisión. Trad. Aurelio Garzón del Camino México: Siglo XXI Editores, 1995.

The Foucault Reader. Ed. Paul Rabinow. New York: Panteon, 1984.

Nietzsche, Freud, Marx. Barcelona: Trad. Alberto González Troyano Editorial Anagrama, 1970.

Freud, Sigmund. El malestar de la cultura. Madrid, Afrodisio Aguado, S. A. Editores, 1966.

Gadamer, Hans-Georg. El inicio de la sabiduría, Barcelona, Piados, 2001.

The Relevanse of the Beautiful and Other Essays. Trans. by N. Walker and Ed. By R. Bernasconi. New York: Cambridge University Press, 1986.

"Pensamiento y poesía en Heidegger y Holderlin" conferencia de las Segundas Jornadas de la Martin Heidegger-Gesellschaft, Mebkirch, 26-27 de sept. 1987. Trad. Angela Ackermann Pilari en Gadamer, H G., Los caminos de Heidegger, Barcelona: Herder, (2002).

Garber, Marjorie et al., eds. The Turn to Ethics. New York, Routledge, 2000.

Gerbi, Antonelo. La naturaleza de los indios nuevos, México: Fondo de Cultura Económica, 1978.

Gomáriz, José. "José Martí en las entrañas de la modernidad". La Habana:

Casa de las Américas, abril-junio (2003): 85-94.

González, Manuel Pedro. José Martí: en el octogésimo aniversario de la iniciación modernista 1882-1962. Caracas: Ediciones del ministerio de educación, 1962.

Guamán Poma de Ayala, Felipe. Nueva crónica y buen gobierno. Madrid: Colección Cronistas de América, Edición Historia 16, 1987.

Guatari, Félix. The Anti-Aedipus Papers. Ed. by Stépnane Nadaud. Tras by Kélina Gotman. New York: Semoitext(e), 2006.

Guillory, John "The Ethical Practice of Modernity: The Example of Reading" en The Turn to Ethics, New York: Routledge, , 2000.

Habermas, Jurgen. "La modernidad inconclusa", Vuelta 54 (mayo 1981): 4-9 
Heidegger, Martin. El ser y el tiempo. Trad. José Gaos. México: Fondo de Cultura Económica, 1974.

Poetry, Language, Thought. Trans. by Albert Hofstaddter. New York: Harper and Row, Publishers, 1975.

---.---.-. Ser, Verdad y Fundamento. Caracas: Monte Ávila Editores, 1968.

Henríquez Ureña, Max. Breve historia del modernismo. 2da. Ed. México: fondo de Cultura Económica, 1962.

Henriquez Ureña, Pedro. Las corrientes literarias en América Latina. México: Fondo de Cultura Económica, 1949.

Howells, Christina. Derrida: Deconstruction from Phenomenology to Ethics. Malden, MA: Blackwell, 1998.

Jameson, Frederic. The Cultural Term: Selected Writings on the Postmodern 1983-1998. Londres: Verso, 1998.

Jiménez Hernández, Adolgo. Unamuno y la filosofia del lenguaje. Barcelona: Editorial San Juan, 1973.

Jiménez, José Olivio. La raiz y el ala: aproximaciones críticas a la obra literaria de José Martí. Valencia: Pre-Textos, 1993.

---------.-. "Un ensayo de ordenación trascendente en los Versos libres de José Marti". Revista hispánica moderna, New York: Casa de las Españas, (1968): 671-684.

--.----- y Carlos Javier Morales. La prosa modernista hispanoamericana. Introducción crítica y antología, Madrid: Alianza Editorial, 1998.

Jiménez, José Olivio y Carlos Javier Morales. La prosa modernista hispanoamericana: introducción crítica y antología. Madrid: Alianza Editorial, S.A. 1998.

Jrade, Cathy. "Martí Confronts Modernity". Re-reading José martí. One Hundred Years Later. Albany: State University of New York, 1999.

Kristeva, Julia. In the Beginning Was Love, New York: Columbia University Press, 1987.

Lamore, Jean. "Historia y biología en la "América mestiza" de José Marti". La Habana Anuario del centro de estudios martianos, No. 2, (1979): 92-110.

Le Riverend, Julio. "El historicismo martiano en la idea del equilibrio del mundo", Anuario del centro de estudios martianos, La Habana: Centro de Estudios 
Martianos, No. 2, (1979): 111-134.

-------.-. "Martí: ética y acción revolucionaria", Anuario del centro de estudios

martianos No. 2, La Habana: Centro de Estudios Martianos, (1970): 123-143.

León Portilla, Miguel. El reverse de la conquista. México: Editorial Joaquín Mortiz, 2001.

Levi-Strauss, Claude. Elogio de la antropología. México: Ediciones Pasado y Presente, 1977.

Levinas, Emmanuel. Ética e infinito. Trad. y notas Jesús María Ayuso Diez. Madrid: La balsa de la medusa, 2da. Ed., 2000.

God, Death, And Time. Trad. Bettina Bergo. California: Stanford University Press, 2000.

--.--.-El tiempo y el otro. Trad. J. L. Pardo e intr. F. Duque. Barcelona: Paidós, 1993.

-------.-. Humanismo del otro hombre. México: Siglo XXI, 1992.

Lezama, Lima, José. Confluencias: selección de ensayos. Comp. Abel E. Prieto. La Habana: Cuba: Editorial Letras Cubanas, 1988.

La casa del alibi., La Habana: Unión, 2001.

Libro de Chilam Balam de Chumayel, Universidad Nacional Autónoma de México, México: 1973.

Lowith, Karl: De Hegel a Nietzsche: la quiebra revolucionaria del pensamiento en el siglo XLX. Marx y Kierkegaard. Trad. Emilio Estú. Buenos Aires: Editorial Sudamericana, 1974.

Lyotard, Jean Francois. The postmodern Condition: A Report on Knowledge. Minneapolis: Minnesota UP, 1991.

A partir de Marx y Freud. Trad. Manuel Vidal. Madrid: Editorial Fundamentos, 1975.

Mañach, Jorge. Martí El Apóstol. Madrid: Espasa Calpe, 1975.

Montaigne, Miguel. Ensayos completos. Trad. Juan G. de Luaces. México: Editorial Porrúa, 1991. 
Marina, José Antonio. Crónicas de la ultramodernidad. Barcelona: Anagrama, 2000.

Marinello, Juan. José Martí: escritor americano. México: Grijalbo, 1958.

Márquez Sterling, Carlos. Sintesis de una vida extraordinaria. México: Editorial Porrúa, 1982.

Martí, José. Obras Completas. La Habana: Centro de Estudios Martianos Edición Karisma Digital. 27 volúmenes. CD-ROM.

Letras fieras. La Habana: Editorial Letras Cubanas, 1981.

Poesía completa. Edición Crítica, La Habana: Letras Cubanas, 2001.

Poesía completa. Ed. Carlos Javier Morales, Madrid: Alianza Editorial, 1995.

Correspondencia a Manuel Mercado. La Habana: Centro de Estudios Martianos, 2001.

Ensayos y crónica., Ed. José Olivio Jiménez. Madrid: Cátedra, 2004.

Diario de campaña: de Cabo Haitiano a Dos Ríos. La Habana: Editorial de Ciencias Sociales, 1978.

Martínez Estrada, Ezequiel. Martí Revolucionario. La Habana: Casa de las Américas, 1974.

Martínez Fortín y Foyo, Carlos A. Código martiano o de ética nacional. Miami: Editorial SIBI, 1986. 1ra ed. La Habana, 1943.

Marx, Karl. Manuscritos: economía y filosofia. Madrid: Alianza Editorial, 1974.

Antología. Ed. Jacobo Muñoz. Barcelona: Ediciones Península, 2002.

Miguel de Mongtaine. Ensayos completes. México: Editorial Porrúa, 1991.

Mignolo, D. Walter. The Darker Side of Renaissance: Literacy, Territoriality and Colonization. Michigan: The University of Michigan Press, 1995.

Morales, Carlos Javier. La poética de José Martí y su contexto. Madrid: Verbum, 1994.

Nehamas, Alexander. The art of Living: Socratic Reflexions from Plato to Foucault. Berkeley: University of California Press, 1998.

Nietzsch, Friedrich. Asi hablaba Zaratustra. Bogotá: Panamericana Editorial, 2000. 
Ecce Homo: como se llega a ser lo que se es. Trad. Andrés Sánchez Pascual. Madrid: Alianza Editorial, 1976.

----.-.-El nacimiento de la tragedia. Trad. Andrés Sanchez Pascual. Madrid: Alianza Editorial, 1973.

Onís, Federico De. "Martí y el modernismo" en Memoria del Congreso de Escritores Martianos. (Año del Centenario del Nacimiento de José Martí), La Habana: 1953.

Ortiz, Fernando. Contrapunteo cubano del tabaco y el azúcar. Pról. María F. Ortiz e intr. Bronislaw Malinowski. Madrid: EditoCubaEspaña (Sucesores de Fernando Ortiz), 1999.

Paris, Diana. Julia Kristeva y la gramática de la subjetividad, Madrid: Campo de Ideas, 2003.

Paz, Octavio. El laberinto de la soledad. Postdata. Vuelta al laberinto de la soledad. México: Fondo de Cultura Económica, 2000.

...-.-.... El arco y la lira. México: Fondo de Cultura Económica, 1973.

---_-.-... Los hijos del limo. Barcelona: Seix Barral, 1974.

-.--1-.-. Las peras del olmo. Barcelona: Seix Barral, 1990.

-.----.. Pasión crítica. Madrid: Seix Barral, 1990.

-.-----. Los signos en rotación y otros ensayos. Sel. y Pról. Carlos Fuentes. Madrid: Alianza Editorial, 1971.

Pérez-Rioja, José Antonio. Diccionario de símbolos y mitos. Madrid: Tecnos, 1971.

Piazze, Juan. "Foucault: poderes-saberes, disciplinamientos y sexualidades. Algunas reflexiones sobre la muerte suscitadas por la ética del cuidado de sí" Revista Observaciones Filosóficas no. 2 (2006): 2-7. http//observacionesfilosoficas/net

Picon G. Evelyn e Iván Schulman. Las entrañas del vacio: ensayos sobre la modernidad Hispanoamericana. México: Ediciones Cuadernos Americanos, 1984.

Platón. Diálogos. Madrid: Editorial El Ateneo, 2001.

Portuondo, José Antonio. Martí, escritor revolucionario. La Habana: Editora Política, 1982. 
Rama, Angel "José Marti en el eje de la modernización poética: Whitman, Lautréamont, Rimbaud", Nueva revista de Filología Hispánica, vol. 32, no.1 (1975): 96-135.

. "La dialéctica de la modernidad en José Marti", en Rama et al. Estudios martianos. Río Piedras: Editorial Universitaria, 1974.

-------.. Transculturación narrativa en América Latina, México: Siglo XXI Editores, 1987.

La ciudad letrada. Hanover: Ediciones del Norte, 1984.

Rivera-Rodas, Oscar. La poesía Hispanoamericana del siglo XIX (Del romanticismo al modernismo), Madrid: Alambra, 1986.

Roig, Arturo Andrés. "Ética y Liberación: José Martí y el 'hombre natural' en Actas del Primer Congreso de Estudios latinoamericanos. Homenaje a José Martí a los 100 Años de "Nuestra América" y Versos sencillos. La plata (sep. 1991).

Rojas Osorio, Carlos J. Foucault y el pensamiento contemporáneo, San Juan: Editorial de la Universidad de Puerto Rico, 1985.

Rodó, José Enrique. Ariel. Buenos Aires: Editorial Kapelusz, 1966.

Rowe, Meter. ed. Compendio de ética. Madrid: Alianza Editorial, 1995.

Russell, Bertrand. La conquista de la felicidad. Barcelona: Editorial Debate, 2000.

Said, Edward. Representations of the Intellectual. Nueva York: Vintage Books, 1996.

Culture and Imperialism. New York: Vintage Books, 1994.

Orientsalism. New York: Vintage Books, 1994.

Sarmiento, Domingo Faustino. Obras completas, Santiago de Chile-Buenos Aires: 18851902, tomo XLVI, Páginas literarias: 166-173.

Schulman, Iván, El proyecto inconcluso: la vigencia del modernismo. México: siglo XXI editores, 2002.

ed. Nuevos asedios al modernismo. Madrid: Taurus, 1987.

Ed. José Martí. Ismaelillo. Versos Libres. Versos Sencillos. Madrid:

Ediciones Catedra, 1992.

Vigencias: Marti y el Modernismo, La Habana, Centro de Estudios Martianos, 2005. 
-Símbolo y color en la obra de José Martí. Madrid: Editorial Gredos, 1960.

y Manuel Pedro González. Martí, Dario y El Modernismo. Madrid: Editorial Gredos, S.A., 1974.

y Evelyn Picon Garfield Las entrañas del vacio: ensayos sobre la modernidad americana. México: Ediciones Cuadernos Americanos, 1984.

y Evelyn Picon Garfield, eds. Poesía modernista hispanoamericana y

Española. Antología 2a. ed. Puerto Rico: Editorial Universidad de Puerto Rico, 1999.

Salvatore, Ricardo, comp. Culturas imperiales. Experiencia y representación en América, Asia y Africa. Buenos Aires: Beatriz Viterbo Editora, 2005.

Sullivan, Lawrence E, edit. Native Religions and Cultures of Central and South America: Anthropology of the Sacred. New York: Continuum, 2002.

Todorov, Tzvetan. La Conquista de América. El problema del otro. México: Siglo XXI Editores, 1997.

Vela, Arquelles, El modernismo: su filosofia. su estética. su técnica. México:

Editorial Porrúa, S.A., 1974.

Vitier, Cintio. Temas martianos 1, La Habana: Letras Cubanas, 2004.

---------, y García Marruz, Fina. Temas martianos, La Habana: Biblioteca Nacional José Martí, 1968.

Martí en Lezama, La Habana: Centro de Estudios Martianos, 2000.

y Daisaku Ikeda. Diálogo sobre José Martí, el Apóstol de Cuna. La Habana:

Centro de Estudios Martianos, 2001.

Vallejo, César. Poesía completa. Ed. Crítica y studio Raúl Hernández Novás. La Habana: Arte y Literatur, 1988.

Walsh, Sylvia. Living Poetically: Kierkegaard's Existential Aesthetics. Pennsylvania: The Pennsylvania State University Press, 1994.

William, Bernard. Ethics and the Limits of Philosophy. Cambridge, Mass.: Harvard University Press, 1985.

Whtiman, Walt. Complete Poetry and Collected Prose. New York: The Library of America, 1982. 
Wood, David, ed. Philosophers' Poets. London: Routledge, 1990.

Zavala, M. Iris. Colonialism and Culture: Hispanic Modernism and the Social

Imaginary. Bloomington and Indianapolis: Indiana University Press, 1992. 


\section{CARLOS E. CENZANO}

1976-1980

B. A., in Education with Double Major

Spanish and Literature, Pedagogical Institute

Santiago de Cuba, Cuba

1980-1982

Spanish Teacher

Vocational High School

Santiago de Cuba, Cuba

1986-1992

Director Cultural Institution

Siboney

Santiago de Cuba, Cuba

I986-1992

University Professor

History of Cuban Culture

Director of Literary Club

University of Santiago de Cuba

Cuba

1995-1997

M. A., in Spanish

Florida International University

Miami, Florida

1996-2004

Spanish Teacher

Advance Placement Spanish and Literature Courses

Sponsor and Editor Spanish Literary Magazine

Miami Beach Senior High

Miami Beach, Florida

2004-2006

Teaching Assistant

Florida International University

Miami, Florida

2007

Miami Dade College

Vocational English for Speakers of Other Languages

Miami, Florida

2008

Ph.D., in Spanish

Florida International University

Miami, Florida 


\section{PUBLICATIONS AND PRESENTATIONS}

Cenzano Carlos E. (Spring, 2006). Espacio y palabra como elementos catárticos en el proceso de liberación de Pascual Duarte. Letras Hispanas, Vol. 3, 1, Spring 2006.

Cenzano, Carlos E. (2006). Dimensión hipertélica del language en la poética de Flores del destierro. Memoria del 52nd Congreso Internacional de Hispanistas, Sevilla 17-23 julio 2006.

Cenzano, Carlos E. (2008). Imagen y trayectoria del ser en el discurso poético de Flores del destierro. Anuario del Centro de Estudios Martianos, publication of the Centro de Estudios Martianos. La Habana, Cuba.

Cenzano, Carlos E. (2004). País de agua. Poetry. (Betania: 2004).

Cenzano, Carlos E. (2008). Papeles de Santiago, Poetry. (Entrerios: 2008).

Cenzano, Carlos E. (Fall, 2004). XXI Miami Book Fair 2004. Presentation País de Agua.

\section{AWARDS}

